*ak RMIS View/Frint Document Cover Sheet tow

This document was retrieved from the Documentation and Records Manaqement (DRM) ISEARCH System. It is intended for Information only and may not be the most recent or updated version. Contact a Document Service Center (see Hanford Info for locations) if you need additional retrieval information.

Accession \#: D196011724

Document \#: SD-WM-ER-532

Title/Desc:

NEUTRALIZED CURRENT ACID WASTE CONSOLIDATION MGMT PLAN

Pages: 198 


\begin{tabular}{|c|c|c|}
\hline $\begin{array}{l}\text { 2. To: (Receiving organization) } \\
\text { Distribution }\end{array}$ & $\begin{array}{l}\text { 3. From: (originating organization) } \\
\text { Waste Tank Process } \\
\text { Engineering }\end{array}$ & $\begin{array}{l}\text { 4. Related EDT No.: } \\
607721\end{array}$ \\
\hline $\begin{array}{l}\text { 5. Proj./Prog./Dept./Div.: } \\
\text { TWRS }\end{array}$ & $\begin{array}{l}\text { 6. Cog. Engr.: } \\
\text { W. J. Powell }\end{array}$ & 7. Purchase Order No.: \\
\hline \multirow{2}{*}{\multicolumn{2}{|c|}{$\begin{array}{l}\text { 8. Originator Renarks: } \\
\text { Approval and Release }\end{array}$}} & 9. Equip./Component No.: \\
\hline & & $\begin{array}{l}\text { 10. System/Bidg./Facility: } \\
\begin{array}{l}241-A Z,-A Y,-A W,-A P,- \\
\text { C-106, 242-A, 702-A }\end{array}\end{array}$ \\
\hline \multirow[t]{3}{*}{ 11. Receiver Remarks: } & & 12. Major Assm. Owg. No.: \\
\hline & & 13. Parmit/Permit Application No.: \\
\hline & & $\begin{array}{l}\text { 14. Requi red Response Date: } \\
1 / 22 / 96\end{array}$ \\
\hline
\end{tabular}

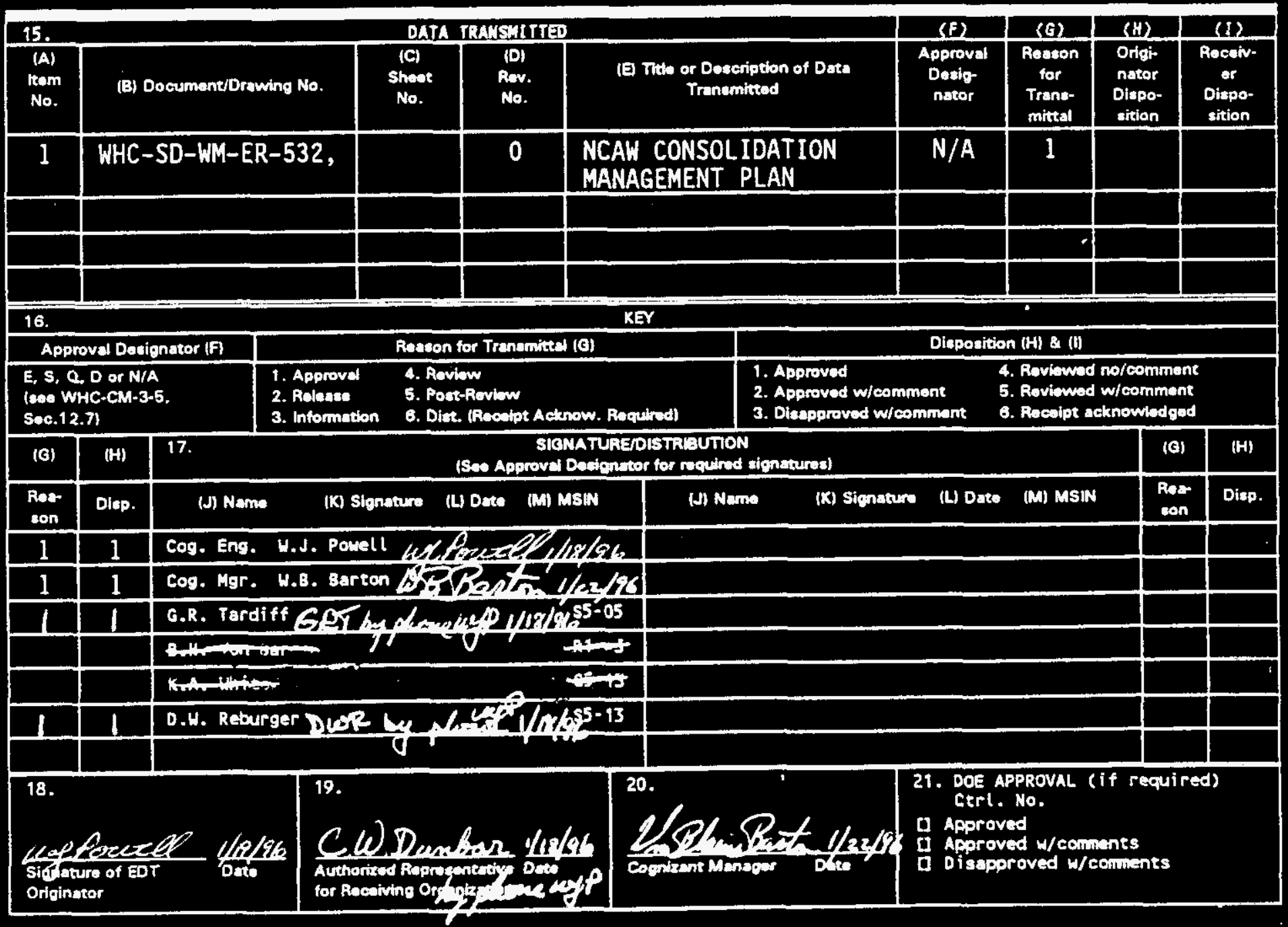




\title{
Neutralized Current Acid Waste Consolidation Management Plan
}

\author{
W. J. Powell \\ Westinghouse Hanford Company, Richland, WA 99352 \\ U.S. Department of Energy Contract DE-AC06-87RL10930
}

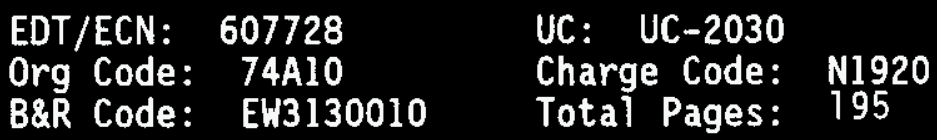

Key Words: NCAW, Neutralized Current Acid Waste, Sludge, C-106, Decision Analysis, Trade Study

Abstract: The scope of this evaluation is to recommend a management plan for the high-heat tank waste, including neutralized current acid waste (NCAW) in AY and AZ Tank Farms, and tank C-106 waste. The movement of solids, liquids, and salt cake in the designated tank farms is included. Decision analys is techniques were used to determine a recommended alternative.

The recommended course of action was replacement of a 75-hp mixer pump in tank AY-102 and in-tank concentration of tank AZ-102 supernate. The alternative includes transfer of tank C-106 sludge to tank AY-102, then transfer of tank AY-102 and tank C-106 sludge to tank AZ-101 using the new 75-hp mixer pump installed in tank AY-102. Tank AZ-101 becomes a storage tank for high-level waste (HLW) sludge, with the capacity to mix and transfer sludge as desired.

TRADEMARK DISCLAIMER. Reference herein to any specific commercial product, process, or service by trade nane, tradenark, manufacturer, or otherwise, does not necessarily constitute or imply its endorsenent, recommendation, or favoring by the United States Government or any agency thereof or its contractors or subcontractors.

Printed in the United States of Mmerica. To obtain copies of this document, contact: WHC/BCS

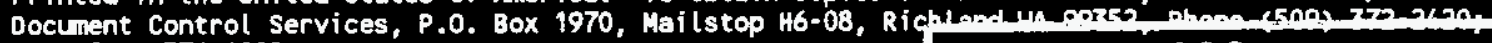
Fax (509) 376-4989.
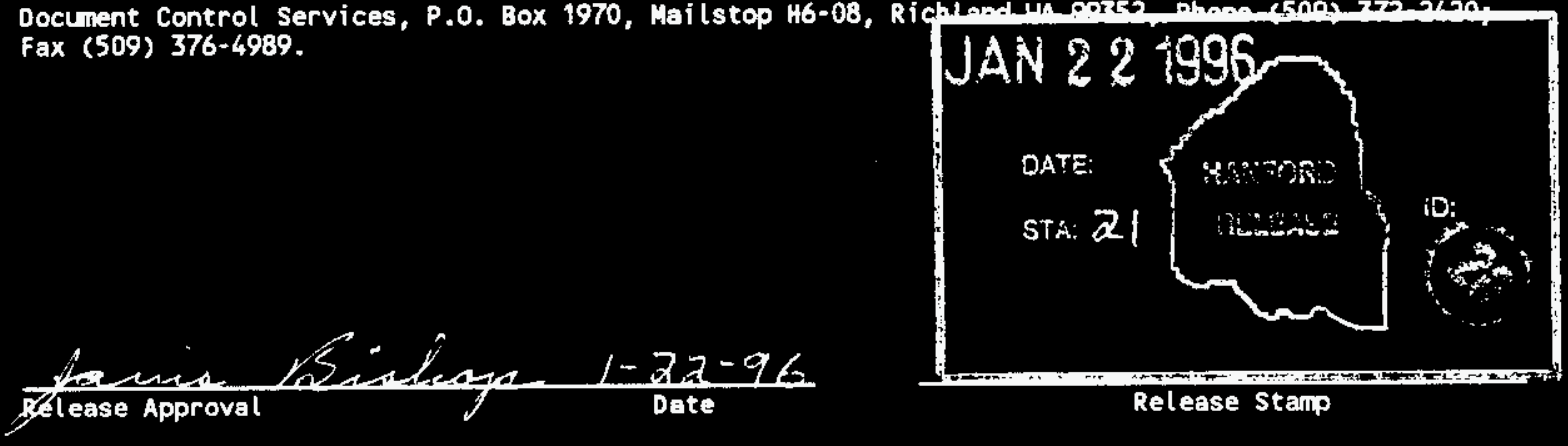

Approved for Public Release 
WHC-SD-WM-ER-532

Revision 0

\title{
NEUTRALIZED CURRENT ACID WASTE CONSOLIDATION MANAGEMENT PLAN
}

\author{
Prepared by \\ W. J. Powell \\ R. G. Brown \\ J. Galbraith \\ C. Jensen \\ D. E. Place \\ G. W. Reddick \\ W. Zuroff \\ Westinghouse Hanford Company \\ Richland, Washington
}

and

A. J. Brothers

Pacific Northwest National Laboratories

Richland, Washington

January 1996 
WHC-SD-WM-ER-532

Revision 0

This page intentionally left blank. 
WHC-SD-WM-ER-532

Revision 0

\section{CONTENTS}

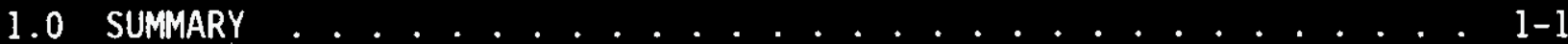

2.0 INTRODUCTION . . . . . . . . . . . . . . . . . . . . 2-1

2.1 PURPOSE . . . . . . . . . . . . . . . . . . . . . . 2-1

2.2 SCOPE AND APPLICABILITY . . . . . . . . . . . . . . . . 2-1

2.3 BACKGROUND ....................... 2-2

2.3.1 Hanford Site..................... 2-3

2.3.2 Tri-Party Agreement ............... . 2-3

2.3.3 Aging Waste Composition ............. 2-4

2.3.4 Criticality ................. 2 24

3.0 TRADE STUDY/MANAGEMENT PLAN .............. 3-1

3.1 SCREENING/ANALYSIS APPROACH .............. . . 3-1

3.2 PRELIMINARY CONSTRAINT LISTING ........... $3-2$

3.2.1 Systems Engineering Functions and Requirements . . . . . 3-2

3.2.2 Decision Criteria . . . . . . . . . . . . . 3-3

3.3 REQUIREMENTS LISTING .............. 3- . . . . . . . . . .

3.4 ALTERNATIVES . . . . . . . . . . . . . 3-11

3.5 INITIAL SCREENING OF ALTERNATIVES ........... 3-13

3.5.1 Screening of Alternatives ............. . 3-13

3.5.2 Summary of Transfers and Analyses . . . . . . . . . . 3-13

3.6 EVALUATION OF REMAINING ALTERNATIVES VERSUS SELECTION

CRITERIA . . . . . . . . . . . . 3-24

3.6.1 Alternative's Satisfaction of Raw Decision Criteria . 3-24

3.6.2 Weighing of Selection Criteria ........ 3-24

3.6.3 Ranking of Alternatives/Analysis . . . . . . . 3-29

3.6.4 Summary of Initial Analysis . . . . . . . 3-35

3.6.5 Sensitivity Analysis .......... 3-. . . . . 35

3.6.6 Comparison of Alternative Pairs . . . . . 3-42

3.7 EVALUATION OF ISSUES AND RISK FOR PREFERRED ALTERNATIVE . . . . 3-42

3.7.1 Risk Analyses: Alternative Ob, Minimal Effort, and Alternative 2, Evaporator Concentrate .... 3-42

3.7.2 Risk Analyses: Aiternatives N1b, Reroute and Consolidate to $A Z-101$, and $N 4$, Reroute and Consol idate to AZ-102 ...... 3-44

3.7.3 Risk Analysis: Alternative $7 \mathrm{~b}, 75-\mathrm{hp}$ Mixer Pump in AY-102, with In-Tank Evaporation ...... 3-44

3.7.4 Risk Analysis Alternative N3, Bottom Decant . . . 3-46

4.0 CONCLUSIONS AND RECOMMENDATIONS ............. . . . . .

5.0 REFERENCES . . . . . . . . . . . . . 5-1

6.0 BIBLIOGRAPHY ............... 6- 6-

7.0 glOSSARY . . . . . . . . . . . . . . 7-1

7.1 ABBREVIATIONS AND ACRONYMS ............ 7-1

7.2 DEFINITIONS . . . . . . . . . . . . 7-1 
WHC-SD-WM-ER-532

Revision 0

CONTENTS (cont)

\section{APPENDIXES}

A COST ESTIMATES . . . . . . . . . . . . . . . A-1

B SCHEDULE ....................... B-1

c SCALE EVAlUATIONS ................. c c-1

D REVIEW COMMENT RECORDS ................ D-1

\section{LIST OF FIGURES}

3-1 Value Hierarchy for Evaluating Neutralized Current Acid Waste Consol idation Alternatives ........... . . 3-4

3-2 Non-Linear Value Functions Used in the Neutralized Current Acid Waste Consolidation Analys is . . . . . . . . . 3-6

3-3 Aging Waste Tank Bump Evaluation . . . . . . . . . 3-7

3-4 Overall Performance on Decision Criteria . . . . . . . 3-30

3-5 Comparison of Team Values with Outlier Values ....... 3-32

3-6 Costs for Neutralized Current Acid Waste Consolidation Alternatives ................... 3-33

3-7 Overall Value Versus Total costs ............ 3-34

3-8 Tank Space Available Versus Safety/Risk . . . . . . . . 3-36

3-9 High-Level Waste Feed Available Versus Safety/Risk . . . . . 3-37

3-10 Sensitivity Study Safety and Risk . . . . . . . . 3-39

3-11 Sensitivity Study Feed Preparation Process . . . . . . . 3-40

3-12 Sensitivity Study High-Level Waste Feed, Tank Space, Schedule . . . 3-41

3-13 Performance Profiles ... . . . . . . . . . . 3-43 
WHC-SD-WM-ER-532

Revision 0

\section{LIST OF TABLES}

1-1 Comparison of Recommended and Backup Alternatives with Planning Case . . . . . . . . . . . . . . . . . . . . . 1-3

2-1 Background Information--High Heat Tanks .............. . 2-5

3-1 Percent Sludge Retrieved From Tanks . . . . . . . . . . . . 3-15

3-2 Percent Sludge Retrieved from AY-102, With and Without 75-hp Mixer Pump........................ . 3-15

3-3 Results of Raw Decision Criteria Evaluation . . . . . . . . . 3-25

3-4 Weights Used in the Analys is of the Neutralized Current Acid Waste Consolidation Alternatives . . . . . . . . . . . . . 3-28

3-5 Consolidation Results . . . . . . . . . . . . . . . . 38 
HHC-SD-WM-ER-532

Revision 0

This page intentionally left blank. 
WHC-SD-WM-ER-532

Revision 0

\section{ACKNOWLEDGHENTS}

The authors of this document would like to acknowledge the assistance of the contributing personnel, including $K$. F. Brown for her evaluations of personnel risk and continued participation with the team; W. L. Knecht for his recommendations and help in the personnel exposure area; G. T. MacLean for his global information, ideas, and contributions in developing background and operating alternatives; T. W. Steahr for his counsel; and T. L. Waldo for the ICF Kaiser Hanford Company cost estimates.

BCS Richland, Inc. editorial and word processing support was provided by L. R. Burks, S. R. Nelson, B. L. Keene, J. K. $011 \mathrm{om}$, and T. B. Mesford of Media Management Systems.

The authors also would like to thank the many Westinghouse Hanford Company personnel who contributed their time to answer questions and provide information.

CONYERSION TABLE

\begin{tabular}{|c|c|c|}
\hline From & To & Multiply by \\
\hline Kgal & $\mathrm{kL}$ & 3.78 \\
\hline gal & $\mathrm{L}$ & 3.78 \\
\hline Ib & $\mathrm{g}$ & 454 \\
\hline inches & $\mathrm{cm}$ & 2.54 \\
\hline
\end{tabular}


WHC-SD-WM-ER-532

Revision 0

This page intentionally left blank. 


\section{WHC-SD-WM-ER-532 \\ Revision 0 \\ NEUTRALIZED CURRENT ACID WASTE \\ CONSOLIDATION MAMAGENENT PLAN}

\subsection{SUMMARY}

As a result of the indefinite postponement of the Multi-Waste Tank Farm (MWTF), specific waste management actions were identified. Included in these actions was a need to consolidate the wastes in the aging waste Tank Farms (AY and $A Z$ ) to maximize storage capacity. In addition, safety considerations have necessitated the retrieval of the wastes in tank $\mathrm{C}-106$ to one of the aging waste tanks (AY-102). Disposal planning includes a mixer pump process test and sludge washing process test in $A Z-101$, and high-level waste (HLW) privatization desires washed-sludge feeds for its Phase 1 denonstration.

The scope of this evaluation is to recommend a management plan for the high-heat tank sludges, including neutralized current acid waste (NCAW) in AY and AZ Tank Farms, and tank $\mathrm{C}-106$ waste. The movement of solids and 1 iquids in the designated tank farms are included. To perform this evaluation, systems engineering decision analys is techniques were used. The management plan and analys is format followed the modified WHC-IP-1101, TWRS Systems Engineering Desk Instruction, TWRS-SE-04, "Trade Study/Decision Analys is" (Eiholzer 1994). The purpose and scope of the investigation have been set and reviewed by cognizant engineers and management.

The results of this study will be used as input to a systems engineering decision process which will establish final Westinghouse Hanford Company (WHC) recommendations for future transmittal to Department of Energy (DOE). Final decisions for WHC will be made by a management decision analys is board.

The initial Planning Case for the NCAW and $\mathrm{C}-106$ consolidation is given in a memo from R. F. Bacon to C. A. August ine (Bacon 1995), which provides instruction to plan to consolidate high-heat sludge from tanks $\mathrm{C}-106$ and $A Z-101$ into tank $A Z-102$. It further directs that Tank Waste Remediation System (TWRS) Engineering and the ongoing systems engineering study (documented in this report) have the responsibility to determine the best alternative and schedule to consolidate high-heat waste from $A Z, A Y$, and C-106 tanks.

Requirements and decision criteria for this study were developed in a top-down perspective from DOE/RL-92-60, Tank Waste Remediation Systems Functions and Requirements (DOE-RL 1993). Weighing of the decision criteria was performed by the six-member team. Two team members did not agree with the consensus team weighting, and their weightings were analyzed as outliers in the sensitivity analysis. Alternatives were brainstormed, revised, and evaluated to the decision criteria, then again modified to obtain the optimum alternative.

Sensitivity studies were developed to determine what would happen if the weighing of individual criteria was changed. The top six alternatives were found to be reasonably insensitive to individual weighting changes of $50 \%$ or more. Other sensitivity studies were performed on the weighting data using 
WHC-SD-WM-ER-532

Revision 0

the two outliers from the team weighting. The outliers did not significantly affect the top alternatives.

Technical safety risks were handled in context with identification of the unresolved safety questions (USQ) required for evaluation of different alternatives. All alternatives except the "Do Nothing" case included fairly high risk due to required USQ evaluations. Key USQ evaluations included: criticality 1 imits, $5 \mathrm{~N}$ sodium rule, tank heat-up and tank bump reevaluations. These USQs should be manageable with prompt recognition of their importance and analysis/action.

The leading alternatives were evaluated for risks. Two of the alternatives (0b, Minimal Effort, and 2, Evaporator Concentrate) contained significant risks related to insufficient HLW feed. In these two a)ternatives, only the $35 \mathrm{Kgal}{ }^{*}$ of sludge currently in AZ-101 would be available for HLW feed.

The recommended course of action was $A 1$ ternative $7 b$, Installation of a 75-hp Mixer Pump in AY-102, including in-tank concentration of AZ-102 supernate. This alternative includes transfer of $\mathrm{C}-106$ sludge to $\mathrm{AY}-102$, then transfer of $A Y-102$ and $C-106$ sludge to AZ-101 using a new 75-hp mixer pump installed in $A Y-102$. Tank $A Z-101$ becomes a storage tank for HLW sludge, with the capacity to mix and transfer sludge as desired.

In Alternative 7b, the HLW feed will undergo one water washing as it is recovered. If a second water washing is necessary, it could be performed as the feed is being transferred to HLW disposal facilities by replacement of the contaminated supernate solution on top of the sludge with dilute supernate.

In these alternatives, it is possible that if tank space becomes constricted enough a $7 M$ sodium solution will have to be placed on top of the HLW feed. This action will again contaminate the solids with sodium, but the solids can be washed prior to transfer to HLW vitrification, or tank AZ-101 can be designated the non-complexed receiver-tank for cross-site transfers. This would provide dilute non-complexed waste for several washings, and conserve required tank space.

The schedule for Alternative 76 shows that the initial supernate and sludge consolidation is complete in fiscal year (FY) 2002, including consolidation of $192 \mathrm{Kgal}$ of sludge in AZ-101 by FY 1998. This timing should be adequate to meet projected HLW disposal needs (FY 2001 startup). Final sludge consolidation ( $f$ inal cleanout of $\mathrm{C}-106$ ) is not complete unt il FY 2003. Final sludge consolidation in FY 2003 has the capability to add about $36 \mathrm{Kgal}$ of sludge to AZ-101, bringing the total HLW sludge in AZ-101 to $228 \mathrm{Kgal}$.

The evaluation team determined that the next best alternative (fallback) is modified Alternative N3, Bottom Sludge Transfer to AY-102 with in-tank concentration of AZ-102 supernate. In this alternative, as much $\mathrm{C}-106$ sludge as possible is transferred from $A Y-102$ to $A Z-101$ by using the bottom transfer system as the C-106 sludge settles. Alternative $N 3$ is a natural fallback if the 75-hp mixer in AY-102 should become inoperable for any reason. This

"See the Conversion Table in front matter of document. 
alternative is modified to perform in-tank evaporation instead of evaporation at the 242-A evaporator. For both A7ternative $7 \mathrm{~b}$ and modified Alternative N3, the option of concentration at the 242-A evaporator becomes a fal1-back position if in-tank evaporation becomes impossible or untimely.

Except where noted, Table 1-1 outlines the raw decision criteria data developed for Alternative 5a, Planning Case (Bacon 1995); the recommended Alternative 7b, 75-hp Mixer Pump in AY-102; and back-up Alternative N3, Bottom Sludge Transfer of settling solids in AY-102 (modified for in-tank concentration of NCAW high-heat supernate). Where noted, individual decision criteria values also are given for the "no leaching" improved Planning Case, Alternative N5a. Comparison of these cases should allow the reader to determine where the differences in the scenarios exist. The main equipment differences between the Planning Case (Alternative 5a) and the 75-hp Mixer Pump in AY-12 (A1ternative $7 \mathrm{~b}$ ) is that in Alternative $7 \mathrm{~b}$, mixing systems do not need to be installed in $A Z-102$; instead, A1ternative $7 b$ replaces an existing, inoperable 75-hp mixer in AY-102 with a new one. This new mixer provides more $\mathrm{C}-106$ waste to $\mathrm{AZ}-101$ than does the Planning Case (Alternative 5a). In the Planning Case, the sludge consolidation tank is $A Z-102$; in the 75-hp Mixer Case, it is AZ-101, which has mixers already installed.

The recommended course of action and the fall back alternative are different from the Planning Case. The recommended alternative has less risk and has a potential for significant cost deferral and avoidance. Total cost is included in Table 1-1, but is an independent variable in the analysis. Cost was not included in the calculation of the total "value" of the alternative. 


\begin{tabular}{|c|c|c|c|}
\hline I & $\mathbf{s}^{*} \mathrm{I}$ & $\varepsilon$ & pana!ıqad SISO to daqunN \\
\hline$Z \cdot I$ & $2 \cdot I$ & I & paysem sabpn Ls ISO to daqunN \\
\hline I & 0 & I & 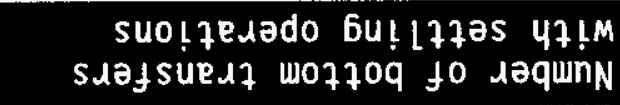 \\
\hline I & 2 & $b$ & $\begin{array}{l}\text { az! ! !qow } \\
\text { of sabpnls ISO to dequinN }\end{array}$ \\
\hline OT & I I & $b I$ & $\begin{array}{r}\text { suo!fes }\lfloor\text { tpou } \\
\text { f!d ssasodd to daqunN }\end{array}$ \\
\hline 0 & I & 0 & $\begin{array}{r}\text { suo!fes!t!pou } \\
\text { aut utedp xuef to daqunN }\end{array}$ \\
\hline $9 \mathrm{I}$ & $\angle 2$ & SI & $\begin{array}{l}\text { Suafsuedq aqeudadns } \\
\text { pue quejap to daqunN }\end{array}$ \\
\hline 2 & 2 & $\downarrow$ & sdefsuedz Kudn [s to dequnN \\
\hline 2 & I & $\downarrow$ & Gutx!u abpn ls to daqunN \\
\hline 0 & 0 & 2 & sayjeal pue saysem fo daqunN \\
\hline & & & oleos pue e!dəq!do uo!s!jog \\
\hline 82 & 62 & $\begin{array}{r}\text { (egN) } 29 \\
(\mathrm{Eg}) 29\end{array}$ & (\$ U0!LL!U) 7s0J Le70L \\
\hline $\begin{array}{r}(\text { pəzеш! } 75 \theta) \\
\angle 9^{\circ} 0\end{array}$ & $\varepsilon L^{\circ} O$ & $\begin{array}{l}\text { (egN) } 89^{\circ} 0 \\
(\mathrm{eg}) \angle 6^{\circ} 0\end{array}$ & 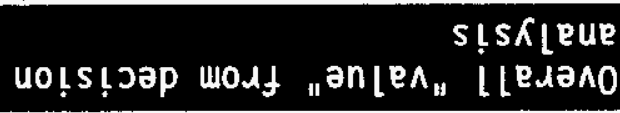 \\
\hline $\begin{array}{r}10 I-Z \forall<< \\
(d 2 x ! \omega] \\
7 n 047 ! M) \\
20[-\lambda \forall<< \\
90[-3\end{array}$ & $\begin{array}{r}\text { I0I-Z } Z<< \\
(\lambda a x ! W \mathrm{~d} y-\mathrm{S} L) \\
20 I-\lambda \forall<< \\
90 I-J\end{array}$ & 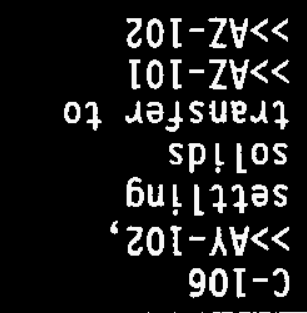 & 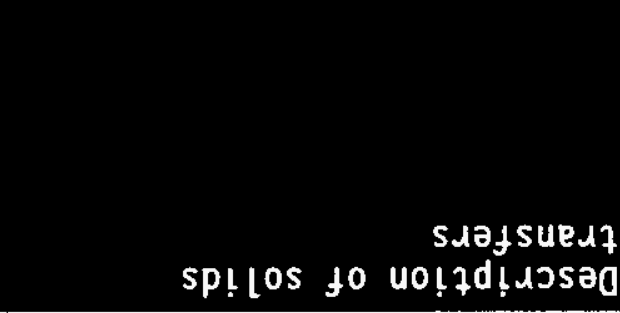 \\
\hline 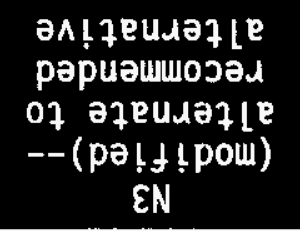 & 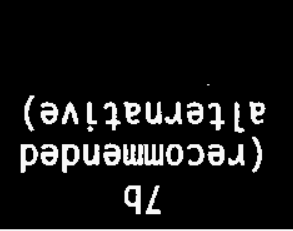 & $\begin{array}{c}\text { (6u!yjeal } \\
\text { әэnpad } \\
\text { of po! } f ! \text { poul) } \\
\text { eg }\end{array}$ & 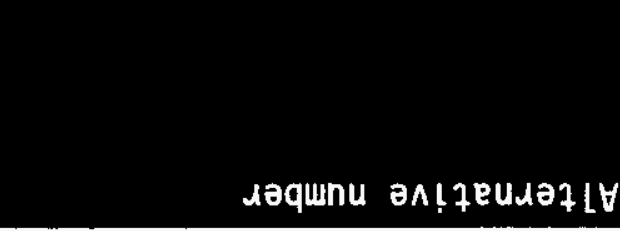 \\
\hline 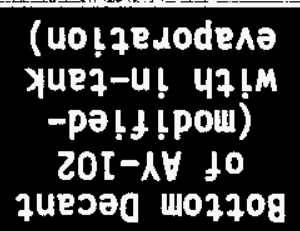 & $\begin{array}{l}\text { (uo!fedodeno } \\
\text { Xueq-u!) } \\
20 \mathrm{~T}-\lambda \mathrm{U} \text { u! } \\
\text { dox!H dy-gL }\end{array}$ & 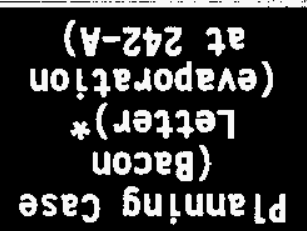 & \multirow[t]{2}{*}{ uo !7d ! גวsea } \\
\hline \multicolumn{3}{|c|}{ 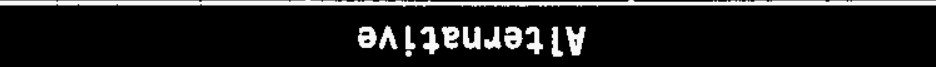 } & \\
\hline
\end{tabular}

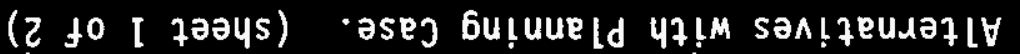
dnyseg pue papuamwosay to uos!ledwoj $[-[$ alqe $\perp$ 
Table 1-1. Comparison of Recommended and Backup Alternatives with Planning Case. (sheet 2 of 2)

\begin{tabular}{|l|l|l|l|}
\hline \multicolumn{1}{|c|}{ Description } & \multicolumn{3}{c|}{ A1 ternative } \\
\cline { 2 - 4 } & $\begin{array}{c}\text { Planning Case } \\
\text { (Bacon } \\
\text { Letter) } \\
\text { (evaporation } \\
\text { at 242-A) }\end{array}$ & $\begin{array}{c}\text { 75-hp Mixer } \\
\text { in AY-102 } \\
\text { (in-tank } \\
\text { evaporation) }\end{array}$ & $\begin{array}{c}\text { Bottom Decant } \\
\text { of AY-102 } \\
\text { (modified- } \\
\text { with in-tank } \\
\text { evaporation) }\end{array}$ \\
\hline Number of DSTs leached & 1 & 0 & 0 \\
\hline $\begin{array}{l}\text { Flexibility in out-years } \\
\text { (number of mixer systems } \\
\text { installed) }\end{array}$ & 2 & 1.3 & 1 \\
\hline Personnel risk (rem) & 24 & 16 & 15 \\
\hline $\begin{array}{l}\text { Offsite personnel risk (waste } \\
\text { transfer pits entered) }\end{array}$ & 22 & 15 & 16 \\
\hline $\begin{array}{l}\text { Tank bump (100\% = best } \\
\text { avoidance, based on sludge } \\
\text { height and heat) }\end{array}$ & $78 \%$ & $65 \%$ & $95 \%$ \\
\hline Number of major USQs required & 3 & 2 & 2 \\
\hline Number of minor USQs required & 9 & 12 & 11 \\
\hline $\begin{array}{l}\text { Number of runs at } \\
\text { 242-A evaporator }\end{array}$ & 1 & 0 & 0 \\
\hline $\begin{array}{l}\text { Fluffy settled sol ids height } \\
\text { (final ft) }\end{array}$ & 10.6 & 15.6 & 9.1 \\
\hline HLW feed available (Kgal) & 223 & 228 & 133 \\
\hline C-106 start (date) & $10 / 96$ & $10 / 96$ & $10 / 96$ \\
\hline End date (year) & 2002 & 2002 & 2002 \\
\hline Tank volume savings (Kgal) & 790 (5a) & 990 & 990 \\
\hline & 990 (N5a) & & 29 \\
\hline
\end{tabular}

*Bacon, R. F., 1995, Double-Shell Tank Waste Consolidation and Retrieval Planning Base Case (internal memo 73510-95-017 to C. A. Augustine et a1., August 29), Westinghouse Hanford Company, Richland, Washington.

DST $=$ Double-shel1 tank

$\mathrm{HLW}=$ High-level waste

USQ $=$ Unresolved safety question 
WHC-SD-WM-ER-532

Revision 0

The following near-term actions are recommended for timely completion of the preferred alternative:

1. A 75-hp mixer pump must be obtained for installation in AY-102 to replace the existing, inoperable 75-hp mixer pump. The purchase of a spare 75-hp mixer pump should be considered to provide a backup to the proposed 75-hp mixer pump. Any other burial equipment required to remove and dispose of the old pump should be designed and obtained.

2. Initiate unresolved safety question (USQ) evaluations for tank bump avoidance scenarios in AZ-101. At least two alternatives are available: one uses the mixer pumps in $A Z-101$ as mitigation devices, and the other alternative uses increased annulus flow in $A Z-101$ as a tank bump mitigation device. Initially, about $75 \%$ of the heat load and sludge volume from $\mathrm{C}-106$ could be used as a design basis.

3. Modify the design of Project $\mathbf{W}-320$ slurry distributor for AY-102. The slurry distributor needs to be able to preferentially place solids in the immediate vicinity of the AY-102 transfer pump. The (now inappropriate) Project $W-320$ slurry distributor is ready for installation.

4. Sample AZ-101 and AZ-102 supernate and perform a boildown in the laboratory to ensure that precipitation will not occur prior to achievement of a $6.5 \mathrm{M}$ to $7 \mathrm{M}$ sodium concentration. Also, evaluate the potential need for a USQ for modifying the $5 \mathrm{M}$ sodium operating specification documentation (OSD) for aging waste supernate. Start in-tank evaporation of AZ-102 aging waste supernate as soon as possible after confirming that precipitation will be limited.

5. Revise criticality prevention specifications to allow consolidation of waste to $A Z-101$ and $A Y-102$.

6. Revise/modify tank heat-up rates of $<1.7^{\circ} \mathrm{C} /$ day $\left(<3{ }^{\circ} \mathrm{F} /\right.$ day) as given in the Operating Specifications for Aging Waste Operations in 241-AY and 241-AZ (Bergmann 1994). Mixer pumps need to be able to be run long enough to mix and transport waste, and to release/move hot spots in the sludge, especially in tank AZ-101.

These activities should be completed by October 1996 to meet the U.S. Department of Energy (DOE) Secretarial Initiative for startup of the tank C-106 waste retrieval system. It may be possible to install the new mixer pump following startup of the $\mathrm{C}-106$ waste recovery, if the initial waste recovery is 1 imited.

The following decisions/actions may be delayed:

- Design of the mixer pump system for AZ-102 as noted in Bacon (1995)

- The USQ evaluation allowing processing of $99 \%$ of $\mathrm{C}-106$ sludge into AZ-101 
WHC-SD-WM-ER-532

Revision 0

- Demonstration of the in-tank leaching process for $\mathrm{C}-106$ waste is not recommended at this time due to impacts to tank space, additional transfers (operational risk) and increased evaporator cost. This evaluation may need to be reanalyzed if tank space becomes available, and appropriate need is shown for HLW vitrification product volume reduction. 
WHC-SD-WM-ER-532

Revision 0

\subsection{INTRODUCTION}

\subsection{PURPOSE}

The purpose of this management plan is to perform a technical evaluation to determine how best to manage tank $\mathrm{C}-106$ and high-heat waste (waste in $\mathrm{AY}$ and $A Z$ Tank Farms) using systems engineering decision logic. This study recommends the best technical alternative and at least one back-up alternative. The decision to implement this recommendation, or some other alternative, will be made by programmatic decision-makers.

The objectives of the study are to determine how to consolidate existing and new waste (from tank $\mathrm{C}-106$ ) in the minimum amount of double-shell tank (DST) space possible, and to position waste for ultimate retrieval activities while avoiding construction of expensive, new facilities. Associated objectives of the study are to provide costs and schedules for the recommended actions.

\section{Basis/Assumptions}

The following are the major basis and assumptions used for the evaluation.

- NCAN consolidation will allow the Hanford Federal Facility Agreement and Consent Order, also known as the Tri-Party Agreement (Ecology et al. 1994) milestones to be met.

- Project performance will be as described in the Design Requirements Document.

- Safety and operating limits can be modified with appropriate documentation and analysis.

- The basis of this analysis will be strictly technical.

- The cutoff point for new information that could influence the study was August 1, 1995, for Revision 0 . Significant program or technical perturbations after that time will be developed in subsequent studies, if necessary.

\subsection{SCOPE AND APPLICABILITY}

The scope of this analysis is the management of the high-heat tank wastes, including NCAW in AY and AZ Tank Farms, and C-106 waste. The movement of solids, liquids, and salt cake in the designated tank farms is included.

Determination of the most appropriate waste management processing scenario is part of the scope, as is development of the cost and schedule of the selected alternative. This study includes investigations that are indepth enough to determine significant issues, but does not attempt to analyze those issues in enough detail to resolve them. Rather, the study identifies 
the issues that will have to be addressed in each alternative, and estimates funding and timing requirements for implementation of the recommended alternative.

The management $p l$ an and analys is followed modified WHC-IP-1101, TWRS Systems Engineering Desk Instruction, TWRS-SE-04, "Trade Study/Decision Analys is (Eiholzer 1994). In addition:

r Qualitative risk analyses for selected alternatives were evaluated in this study.

- After the August 1, 1995, cutoff date for new material, interim procedures WHC-IP- TSEP-07, Decision Management (Interim) (WHC 1995a) and WHC-IP- TSEP-03, A7ternative Generation and Selection (Interim) (WHC 1995b) were issued. These procedures were briefly reviewed and compared to the desk instructions. The decision was made to follow the desk instructions.

- The results of this management plan will provide information to ongoing projects concerning selection of the tanks in which to install mixing and transfer equipment, and how to expect to use the equipment from a process management standpoint. This analysis also will provide a basis for scheduling and funding that should allow implementation of the recommendations.

\subsection{BACKEROUND}

On January 13, 1995, West inghouse Hanford Company recommended to the U.S. Department of Energy, Richland Operations Office that Project W-236A, Multi-Function Waste Tank Facility, be phased out (Alumkal 1995). The MultiFunction Waste Tank Facility Phase Out Basis, WHC-SD-W236A-ER-021 (Awadalla 1995) notes that the most recent information shows that wastes in the TWRS current baseline can be managed within the existing waste tank capacity through FY 2003. Additional DST storage capacity is not needed until FY 2004 or later.

Nine major assumptions that need to become reality to avoid building new tanks are identified (Awadalla 1995). The first assumption is that NCAW needs to be consolidated with $\mathrm{C}-106$ to provide about $980 \mathrm{Kgal}$ of tank space. This report was initiated by the need to determine how NCAN and C-106 wastes could best be consolidated to meet the needs of the Hanford Site. Awadalla (1995) further notes that "managing the present and projected wastes within the existing DST system requires accepting increased risk, and implementing several new waste management actions." An example of this is the decision to continue to use the existing mixing pump to mitigate the flammable gas safety issue in tank SY-101.

The initial Planning Case for the NCAW and $\mathrm{C}-106$ consolidation is given in a memo from R. F. Bacon to C. A. August ine (Bacon 1995), which provides instruction for planning to consolidate high-heat sludge from tanks $\mathrm{C}-106$ and $A Z-101$ into tank $A Z-102$. It further directs that TWRS Engineering and the ongoing systems engineering study (documented in this report) have the responsibility to determine the best alternative and schedule to consolidate high-heat waste from $A Z, A Y$, and $C-106$ tanks. 
WHC-SD-WM-ER-532

Revision 0

\subsubsection{Hanford Site}

In 1943, the U.S. Army Corps of Engineers selected an area of about $600 \mathrm{mi}^{2}$ in semiarid southeastern Washington State for producing plutonium and other nuclear materials supporting weapons' production for World War II. This area, called the Hanford Site, is divided into three major operation areas supporting plutonium production: the 100 Areas for reactor operations; the 200 Areas for fuel reprocessing, plutonium recovery, and waste managenent; and the 300 Area for fuel fabrication.

Liquid waste from the separations processes in the 200 Areas was neutralized and piped to large tanks, several of which comprise a tank farm.

The initial radionuclide separations process was the bismuth phosphate process used in B and T Plants. It generated large amounts of dilute waste in comparison to the later reduction and oxidation (REDOX) and plutonium uranium reduction and extraction. (PUREX) separations processes. Waste tanks were equipped to contain boiling waste and used air-lift circulators (ALC) to keep the tank contents mixed. The 241-AZ and -AY tanks comprise two DST farms that have two aging waste tanks (AWT) in each farm; each tank was designed to contain boiling waste. Each tank in AY and AZ Tank Farms has 22 ALCs which are used to control temperatures in the tanks. These ALCs were shut off in tank AZ-101 in 1993 to determine if a settle/decant process could safely be used (Winkler 1995). This test was a success and all the ALCs in AWTs have been turned off since 1993.

There are 149 single-shell tanks (SST) and 28 DSTs in the 200 Area of the Hanford Site. Tank C-106 is one of these SSTS located in the 200 East Area near the $A Y$ and $A Z$ Tank Farms. Project $W-320$ is planning to sluice the solids from C-106 to AY-102 starting about October 1996. Sluicing will demonstrate initial cleanout of an SST.

\subsubsection{Tri-Party Agreenent}

In 1993 and early 1994, the Tri-Party Agreement was renegotiated (Ecology et a1. 1994). The Tri-Party Agreement revision shifts the emphasis from early HLW vitrification to early low-level waste (LLW) vitrification. Certain chemical separations must al so be deployed earlier to support LLW vitrification. Separations for the new basis are focused on cesium removal from LLW. An enhanced sludge-washing process emerged as the reference strategy.

Major milestones driving the LLW program became: M-60-04, Initiate hot operations of the LLW vitrification facility (June 2005); and M-60-00, Complete vitrification of Hanford low-level tank waste (December 2028).

Other programs affected include HLW, which deleted the M-03 series of milestones for the Hanford Waste Vitrification Plant and established a new series $(M-51)$ for HLW vitrification. A significant milestone in this effort is M-51-03, Initiate hot operations of the HLW vitrification facility (December 2009). 
New Tri-Party Agreement milestones for the SSTs include M-45-03A, Initiate sluicing retrieval of C-106 (October 1997), and M-45-03-T02, Initiate final retrieval demonstration of $\mathrm{C}-106$ (June 2002).

In 1994, the startup of $\mathrm{C}-106$ retrieval became a DOE Secretarial Initiative with a startup date of October 1996. This accelerated startup is not part of the Tri-Party Agreement.

\subsubsection{Aging Waste Composition}

The following values in Table 2-1 were used in the analys is to calculate consolidated sludge volume and heat content.

\subsubsection{Criticality}

The criticality concerns of the proposed waste transfers among tanks $A Y-101, A Y-102, A Z-101$, and AZ-102, and the waste transfer from $C-106$ and AY-102, were reviewed. Discussion and analysis are given in Appendix C. Because this consolidation involves a major revision or exception to the criticality specifications, it could be a major issue in the consolidation of waste in $\mathrm{C}-106$ and AWTs.

It was concluded by this review that no actual criticality concerns exist for tank-to-tank transfers of waste because the minimum concentration of plutonium required to cause a criticality is $2.6 \mathrm{~g} / \mathrm{L}$ in a very large volume (Sederburg 1994). The minimum plutonium concentration that can cause a criticality in a liquid system is about $7 \mathrm{~g} / \mathrm{L}$. No known mechanism capable of approaching possible criticality through concentration of plutonium in a receiver tank exists.

The specification documents must be revised or an exception made to reflect the acceptance of the planned transfers into and within the AWTs. 
Table 2-1. Background Information--High Heat Tanks.

\begin{tabular}{|c|c|c|c|c|c|c|c|}
\hline \multirow{2}{*}{ Tank } & \multirow{2}{*}{$\begin{array}{l}\text { Existing } \\
\text { sludge } \\
\text { volume } \\
\text { (Hanlon } \\
1995 \text { ) } \\
\text { (kgal) }\end{array}$} & \multicolumn{2}{|c|}{$\begin{array}{l}\text { Heat generation } \\
(\mathrm{KBtu} / \mathrm{h})\end{array}$} & \multicolumn{2}{|c|}{ Specific gravity } & \multicolumn{2}{|c|}{ Total organic carbon } \\
\hline & & Liquid & sludge & Liquid & studge & $\begin{array}{l}\text { Liquid } \\
\text { (gC/L) }\end{array}$ & $\begin{array}{l}\text { sludge } \\
\text { (gC/Kg) }\end{array}$ \\
\hline$A Z-101$ & 35 & $90-110^{6}$ & $143 \div 180^{b}$ & 1.2 & 1.7 & $0.87 \mathrm{gc} / \mathrm{kg}$ & 9.2 \\
\hline AZ-102 & 95 & $54 \cdot 80^{b}$ & $120-150$ & 1.1 & 1.4 & $1.4 \mathrm{gC} / \mathrm{kg}$ & 2.65 \\
\hline$A Y-102$ & 32 & Surall & $40^{f}$ & 1.0 & 1.4 & 0.08 & 16.5 \\
\hline AY-101 & 83 & Small & 80 & 1.1 & $N / A$ & $3.4^{\mathrm{c}}$ & $25^{d}$ \\
\hline$c-106$ & 197 & Singll & $110-130^{\circ}$ & 1.2 & 1.4 & $20-2.5$ & $7.5-4.6$ \\
\hline
\end{tabular}

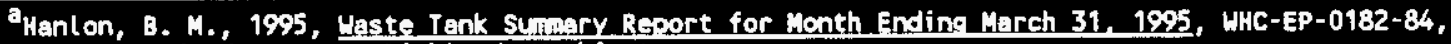
West inghouse Hanford Company, Richland, Washington.

barger values calculated from RADMUC total about $20 \%$ greater than those found in the TCR (Hodgson, K. M., 1995, Iank Characterization Report for Double-shell Tank 241-A2-101,

WHC-SD-LW-ER-410, Rev. 0, Westinghouse Hanford Company, Richland, Washington; and Ryan, G. W., 1995b, Tank Characterization Regart for Double-Shell Iank 241-A2-102, WHC-SO-Lin-ER-411, Rev. 0, West inghouse Hanford Company, Richtand, Washington).

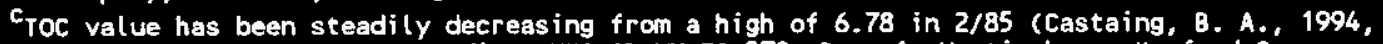
101-AY, 102-AY \& 106-C. Data Comoendivm, WHC-SD-WM-TI-578, Rev. 1, West inghouse Hanford Company, Richtand, Washington) to a low of 3.38 in 1994 (Vogel, R. E., 1994, Results for Tank 241-AY-101 (internal meno 8E480-94-108 to J. M. Jones, October 19), Westinghouse Hanford Company, Richland, Uashington.)

The $246 \mathrm{~g} / \mathrm{Kg}$ value given as an upper limit in the TCR (Castaing 1994 [see footnote $\mathrm{c}$ for reference citation]) was nomalized to $100 \%$ with few anions included and is not appropriate for this appl ication.

Project $W-320$ information and others--best estimate.

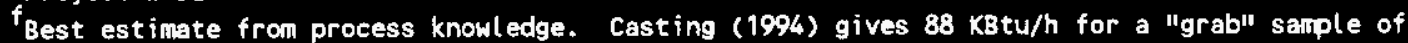
the sludge.

The above values are from the respective TCR unless noted otherwise (Ryan, G. W., 1995a, Iank Characterization Report for Double-Shell Iank 241-AY-102, WHC-SD-WM-ER-454, Rev. O, West inghouse Hanford Company, Richland, Washington; and Ryan, G. W., 19\%5b, Iank Characterization Report for Double-shell Tank 241-A2-102, WHC-SD-My-ER-411, Rev. 0, Uest inghouse Hanford Collpany, Richland, Uashington; Hodgson $19 \% 5$ [see footnote b for reference citation]; Castaing 1994 [see footnote c for reference citation]).

$N / A=$ Not apolicable

TCR = Tank Characterization Report

TOC = Total organic carbon 
WHC-SD-WM-ER-532

Revision 0

This page intentionally left blank. 
WHC-SD-WM-ER-532

Revision 0

\subsection{TRADE STUDY/MANAGENENT PLAN}

\subsection{SCREENING/AWALYSIS APPROACH}

This section presents a comprehensive analys is of the performance of NCAW HLW technical alternatives on values and objectives. The methodology used for the analysis, the values that were identified, how performance was measured, the performance of alternatives, the results of the analysis, and a discussion of the results are described.

Decision analysis was used to guide the collection and analysis of data and the logic of the evaluation. Decision analys is is a structured process for the analysis and evaluation of alternatives. It is theoretically grounded in a set of axioms that capture the basic principles of decision making (Von Neumann and Morgenstern 1947). Decision analys is objectively specifies what factors are to be considered, how they are to be measured and evaluated, and their relative importance. The result is an analys is in which the underlying rationale or logic upon which the decision is based is made explicit. This makes possible open discussion of the decision basis in which facts and values are clearly distinguished, resulting in a well-documented decision that can be clearly explained and justified.

The strategy of decision analysis is to separately analyze the various components relevant to the decision and then to integrate the individual judgments to arrive at an overall decision. This ensures that all the relevant factors are identified and their relative importance is considered. The procedure for obtaining the individual judgments, and the decision rules for combining them and evaluating alternatives, has both theoretical and empirical foundation in mathematics, economics, and psychology.

Decision analysis makes use of numbers rather than qualitative expressions to construct scales, represent preferences, and express uncertainties. The relationship between qualitative preference structures and quantitative scales is given a precise and rigorous description in the discipline of measurement theory (Krantz et al. 1971), which is part of the theoretical foundation of decision analysis. An understanding of the logic of these relationships is especially important when there are multiple, possibly conflicting, objectives to be considered in the analysis. The standard reference for multi-attribute decision analysis is Decisions with Multiple objectives: Preferences and Value Tradeoffs (Keeney and Raiffa 1976). Decision analys is also has formal procedures for considering uncertainty in the analysis. This makes it possible to evaluate the risks associated with each of the alternatives.

The steps in the decision analys is process are as follows.

- DEFINE SCOPE, PURPOSE AND BASIS

- OBTAIN CONSTRAINTS AND REQUIREMENTS

- BRAINSTORM ALTERNATIVES

- PERFORM INITIAL SCREENING OF ALTERNATIVES AGAINST CONSTRAINTS 
WHC-SD-WM-ER-532

Revision 0

- DETERMiNe hOW WELl. EACH aLternative SATISFIES EACH SELECTION CRITERION

- PROVIDE UNBIASED WEIGHTING OF THE SELECTION CRITERIA

- SELECT THE BEST ALTERNATIVE

- PERFORM SENSITIVITY AND CONTINGENCY ANALYSES

- eVALUATION OF ISSUES AND RISKS FOR PREFERRED ALTERNATIVE.

This is an iterative process in which some of the steps are interactive. The general framework holds whether a few simple calculations or an extremely complex and detailed analysis are performed. The extent of the analysis is guided by the stakes involved and the difficulty of the decision. Time is also an important consideration. The objective of any analys is is to specify the decision basis and arrive at a clear course of action. A sound strategy is to error, initially, on the side of simplicity, and to extend the complexity of the analysis as necessary.

\subsection{PRELIMINARY CONSTRAINT LISTING}

This section describes the various components that formed the basis of the analysis.

\subsubsection{Systems Engineering Functions and Requirements (F\&R)}

The TWRS F\&R document, DOE/RL-92-60 (DOE-RL 1993), was used to determine topics of relevance from a top-down system architecture. Because 1 imited detailed requirements were available from this document, only major topics of interest are 1 isted herein. These major topics were considered when proposing the evaluation requirements and criteria.

As defined in DOE/RL-92-60, the mission of the TWRS program is: "to store, treat, and immobilize highly radioactive Hanford waste in an environmentally sound, safe and cost effective manner."

The following major topics that are considerations in this study are 1 isted in DOE/RL-92-60:

- Remediate Tank Waste, Section 4.2, repeats the TWRS mission statement listed above

- Manage Tank Waste, Section 4.2.1, includes safe compliant storage, waste characterization, waste retrieval, waste concentration, and waste transfer

- Process Waste, Section 4.2.2, includes pretreating tank waste to separate the LLW, HLW, and transuranic (TRU) waste. Immobilize the HLW and TRU. Section 4.2.2 also includes interim storage. 
- Pretreat Waste, Section 4.2.2.1, indicates that the tank waste will be separated into an HLW/TRU fraction and an LLW fraction suitable for immobilization. Pretreatment includes preparing al1 retrieved tank waste for separations processes.

- Section 4.2.2.1, C10, includes Tri-Party Agreement Milestone M-50-03, Complete evaluation of enhanced sludge washing to determine whether advanced sludge separation processes are required. A plan for meeting this milestone is provided in WHC-EP-0805, Enhanced Sludge Washing Evaluation Plan (Jensen 1994). The focus of the plan is a decision model and laboratory testing with tank waste, and a sludge washingprocess test in tank AZ-101. The milestone is met with this development. The plan indicates that further in-tank testing is anticipated by slurrying $A Z-101$ solids to $A Z-102$ and then performing a process test for sludge washing in $A Z-102$. This last solids movement is not part of the Tri-Party Agreement milestones.

- Immobilize HLW/TRU Waste, Section 4.2.2.2, immobilizes pretreated HLW and TRU waste. Section 4.2.2.2.I7 provides required tank characterization information.

- Manage System Generated Waste and Excess Facilities, Section 4.2.3

- TWRS, Section 4.2, includes managing existing tanks, operations buildings, vaults, and new facilities needed to accomplish the TWRS mission.

These topics were used as reminders to ensure that global issues were not forgotten and are represented in the detailed criteria.

\subsubsection{Decision Criteria}

Decision criteria are statements of what performance factors are important in the evaluation of alternatives. Figure 3-1 shows the criteria that formed the basis for this analysis. These values resulted from a series of workshops with technical personnel. Associated with the values are measurable scales that clearly define the degree to which the objectives are achieved. The objectives have been derived from technical considerations specific to this decision, but they can easily be related to a more general set of public values that have been identified in numerous previous studies. The values are intended to be an inclusive set that captures all the technical concerns relevant to deciding between NCAN consolidation alternatives.

The identified values, as shown in Figure 3-1, consist of maximizing safety and minimizing risk, maximizing the feed preparation process (for separations and treatment), maximizing the available tank space, optimizing schedule, and minimizing costs. Each of these values has been further specified to capture all aspects of interest in the value. Thus, minimizing risk has been further specified as operational risk and technical risk. 
WHC-SD-WM-ER-532

Revision 0

Figure 3-1. Value Hierarchy for Evaluating Neutralized Current Acid Waste Consolidation Alternatives.

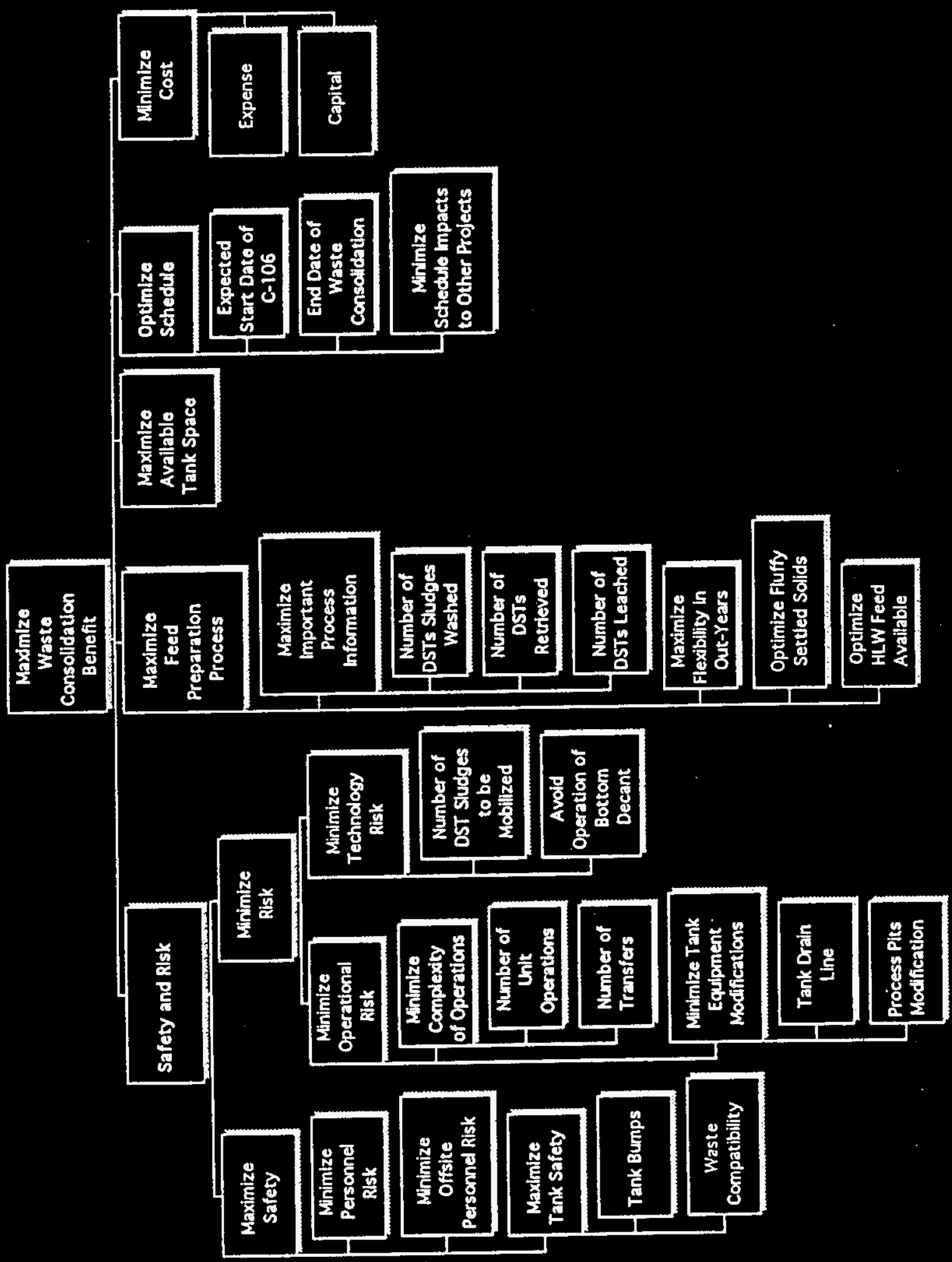


At each level of specification the value immediately above in the hierarchy is partitioned in a way that breaks out all aspects of the value while minimizingany overlap. The specification of values was carried out until a level was reached that consisted of specific criteria for which a scale could be identified for precisely measuring the performance of each alternative. For example, tank safety is further specified as tank bumps and waste compatibility. Waste compatibility was further specified as the number of major and minor non-tank bump safety USQ evaluations required.

3.2.2.1 Criteria/Scales. The criteria scales were identified to determine end points in the value hierarchy and make possible well-defined measurement of the degree to which the objectives were achieved. The scales have been selected with the alternatives in mind to make the collection of performance data reasonable, considering the time and effort available. The scales used in the analysis are shown in hierarchical fashion (see the outline in Subsection 3.2.2.3).

Several types of scales are used in the analysis. The scales may be natural or constructed, and either type may be a proxy scale that provides an indirect measure of the value of concern (Keeney and Raiffa 1976). Natural scales are those that have a common, we11-understood interpretation with a unit of measurement that people naturally associate with measurement. For example, "dollars" is a natural scale for the objective to minimize cost. Constructed scales consist of a series of short scenarios or descriptions that represent different levels of performance on the objective. "Tank bumps" is a constructed scale for one aspect of "maximize tank safety", Figure 3-3. This scale considers the depth of the waste in inches and heat in british thermal units per hour (Btu/h). Combinations of these units were identified as scenarios that represent different levels of performance. These were assigned values ranging from 0 to 100 . The numbers ranging from 0 to 100 that are associated with the constructed scales are value functions that capture the relative importance of different levels of performance.

3.2.2.2 Value Functions. Value functions were assessed to measure the relative importance of different levels of performance on each of the criteria. Value functions translate the various levels of performance as measured by the scales and map it onto either the unit interval or a 0-to-100 range. Value functions capture the fact that, for a given objective, more may be better or worse, and they reflect the fact that changes in importance of different levels of an objective may not be linear with its scale. They also capture the fact that for some objectives, value is non-monotonically related to scale (e.g., there may be some optimum score above and below whose value is less; the optimum number of feet of fluffy settled solids is ten, for example). Value functions were developed based on discussions anong the engineers and the analyst in the workshops. Value functions for eight of the criteria were judged to be non-linear. Six of these value functions are shown in Figure 3-2. For example, consider the value function for the number of DSTs leached. This is valuable to the extent that it provides important process information. Leaching one tank gets a score of 60 , and leaching two tanks receives a score of 90 . This reflects the judgment that the information provided by the second leaching would only have an additional value of one-half the information gained by leaching one tank instead of none. 


\section{WHC-SD-WM-ER-532}

\section{Revision 0}

Figure 3-2. Non-Linear Value Functions Used in the Neutralized Current Acid Waste Consolidation Analysis.

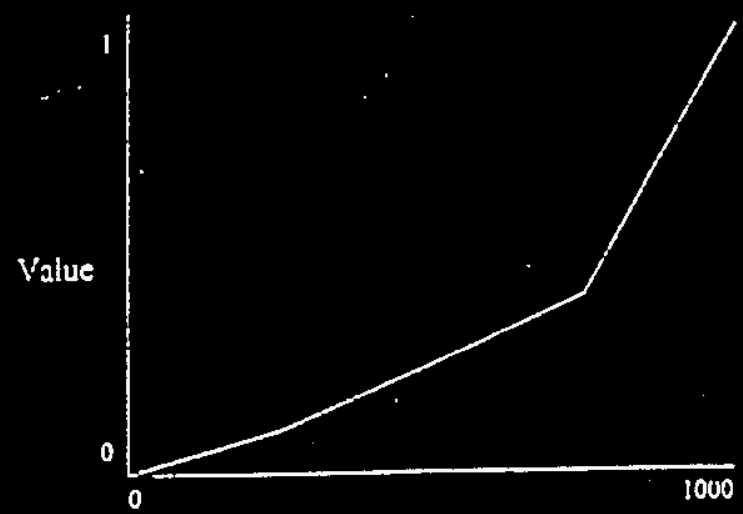

Avail Tank Space (K gal)

Preiérence Set * Group.Set

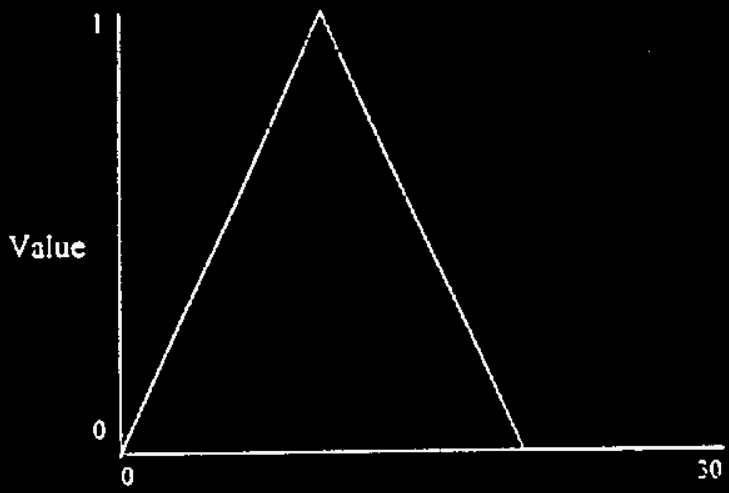

Fluffy seltled solids (\# feet)

Prelerence Seft - Group.Set

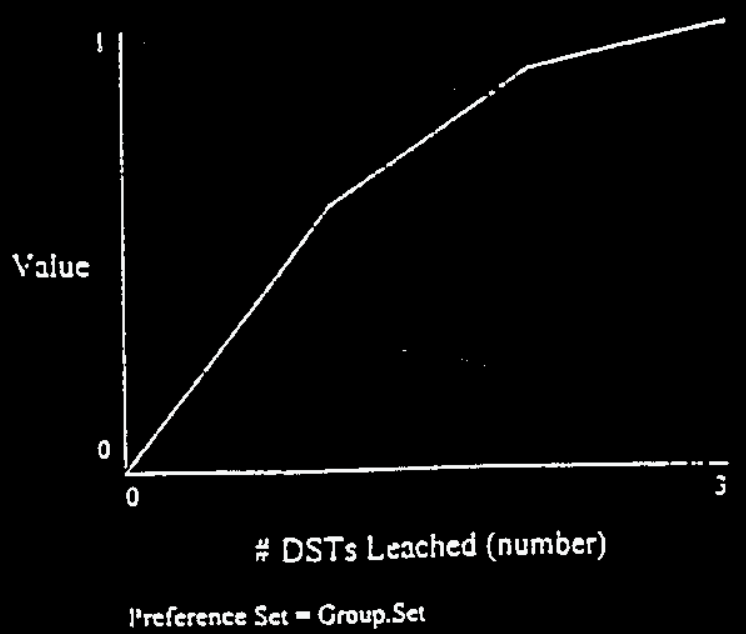

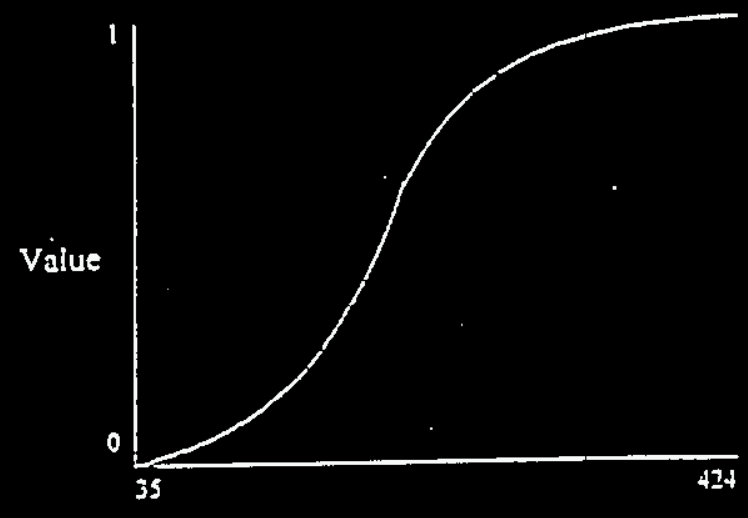

HLW Feed Available (Kgal)

J'reference Set $=$ Group.Set

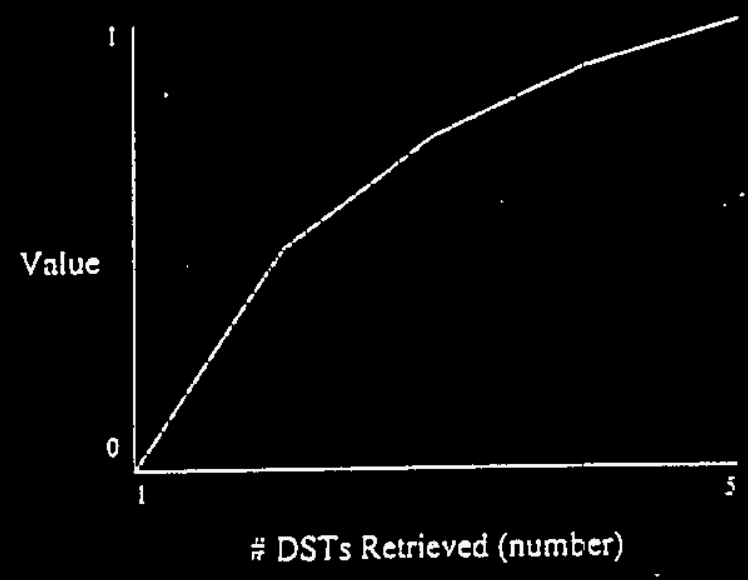

Preference Set $=$ Group.Set

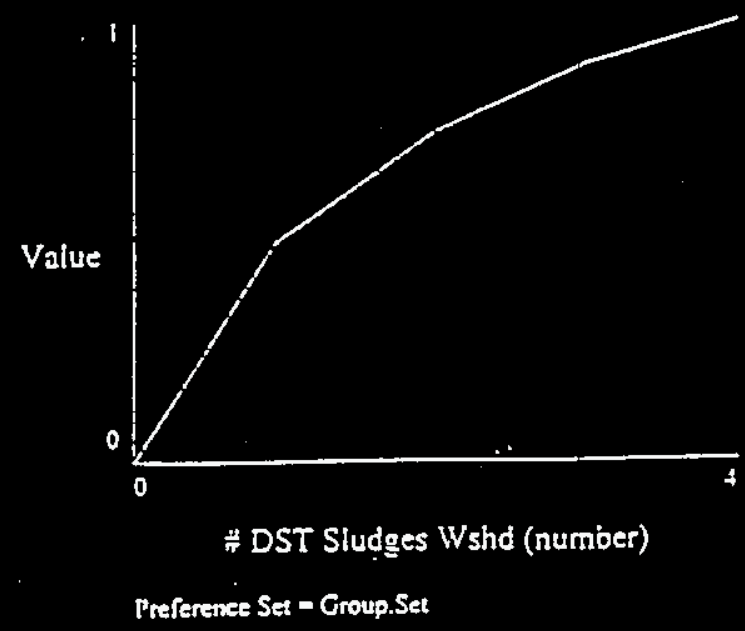


WHC-SD-WM-ER-532

Revision 0

Figure 3-3. Aging Waste Tank Bump Evaluation.

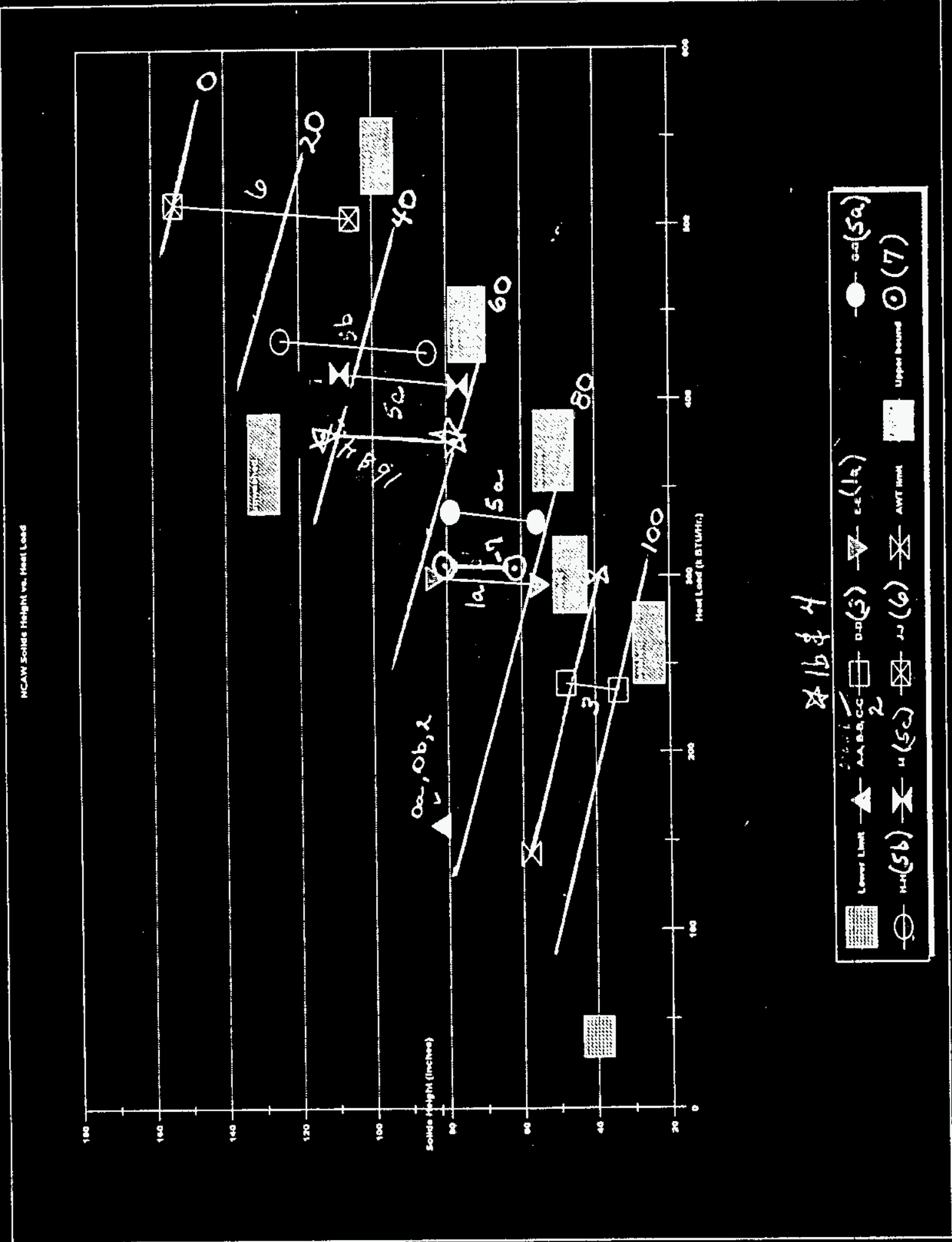




\section{WHC-SD-WM-ER-532}

Revision 0

3.2.2.3 Decision Criteria. The preliminary decision criteria were evaluated, modified, and reorganized in a hierarchy system as shown in Figure 3-1. The hierarchy system was organized in outline form, as shown below, with the scales that were used to evaluate the alternatives.

I. Maximize Safety

A. Minimize personnel risk

1. Radiation dose to personnel (mrem exposure)

a. mrems of exposure from tank samples

b. mrems of exposure from removal of failed pumps or other equipment (pulling equipment)

c. mrems of exposure from installation of equipment

d. mrems of exposure from jumper changes

B. Minimize offsite personne] risk

1. Number of jumper changes

C. Maximize tank safety

1. Tank bumps (see Figure 3-3)

a. For solids $>27 \mathrm{~cm}(10.7 \mathrm{in}$.) heat load versus sludge height requirement

2. Waste compatibility (major and minor USQS)

a. Total number of major safety USQs (potential sources)

(1) Evaporator accident, waste $<6 \mathrm{Ci} / \mathrm{gal}$

(2) Criticality, $<50 \mathrm{plutonium} \mathrm{Kg} /$ tank (OSD)

(3) Tank heat-up rate, $<1.7^{\circ} \mathrm{C} /$ day $\left(<3{ }^{\circ} \mathrm{F} /\right.$ day)

b. Total number of minor safety modifications (potential sources)
(I) Criticality
- $\leq 200 \mathrm{~g}(0.4 \mathrm{lb})$ plutonium/transfer
- $\leq 0.05 \mathrm{~g}(0.01 \mathrm{lb})$ plutonium/gal
(2) $5 \mathrm{M}$ Na rule (OSD)
(3) 90-day rule (OSD)
(4) Hydroxide concentration (OSD)
(5) Air-lift circulator operation (operating safety requirements [OSR]/OSD)
(6) Shielding <6 Ci/gal, tank farms/evaporator; and special evaporator areas $<3 \mathrm{Ci} / \mathrm{gal}$
(7) Mixing NCAW with other wastes (data quality objective)

\section{Minimize Operational Risk}

A. Minimize complexity of operations

1. Number of unit operations

a. Number of runs of concentrated high-heat waste from evaporator

b. Number of sets of wash and leaches

c. Number of sludges mixed

2. Number of Transfers

a. Number of solids transfers

b. Number of decant and supernate transfers

B. Minimize tank equipment modifications

1. Tank drain line

a. Number of tanks that exceeds a solids level of $152 \mathrm{~cm}$ (60 in.)

2. Process pits modification

a. Number of rigid jumpers requiring cover block modification 
WHC-SD-WM-ER-532

Revision 0

III. Minimize Technology Risk

A. Number of DST sludges to be mobilized, (Mono decreasing linear value function)

B. Avoid operation of bottom decant (number of bottom decants)

IV. Maximize Feed Preparation Process

A. Maximize important process information

1. Number of DST sludges washed
a. $0 \%=0$
b. $50 \%=1$
c. $75 \%=2$
d. $90 \%=3$
e. $100 \%=4$

2. Number of DSTs retrieved
a. $0 \%=0$
b. $\quad 50 \%=1$
c. $75 \%=2$
d. $90 \%=3$
e. $100 \%=4$

3. Number of DSTs leached
a. $0 \%=0$
b. $60 \%=1$
c. $90 \%=2$
d. $100 \%=3$

B. Maximize flexibility in out-years processing

1. Number of tanks with mixer pumps (linear-scale mono increasing)

C. Optimize fluffy, settled solids

1. 0 to $6 \mathrm{~m}(0$ to $20 \mathrm{ft}$ ) have value for potential washing scenarios

2. $3 \mathrm{~m}(10 \mathrm{ft})$ is optimum (triangular scale $0 \mathrm{ft}$ and $6 \mathrm{~m}[20 \mathrm{ft}]$ are zero, $3 \mathrm{~m}[10 \mathrm{ft}]$ is 100), See Figure 3-2

D. Optimize HLW feed available

1. Range $35 \mathrm{Kgal}$ to $424 \mathrm{Kgal}$

a. Scale is "lazy $S^{n}$ curve with $50 \%$ point at about $155 \mathrm{Kgal}$, Figure 3-2

V. Maximize Available Tank Space

A. Number of gallons of space potentially made available in FY 2004

1 . O gal to 1 million gal $(0 \mathrm{~L}$ to $3,800,000 \mathrm{~L})$, Figure $3-2$

VI. Optimize Schedule

A. Expected start date of C-106 transfer (1 inear scale with 2 slopes)

I. $10 / 96)=100 \%$

2. $4 / 97=10 \%$ (inflection point)

3. $10 / 97=0 \%$

B. End date of waste consolidation (linear scale with 2 slopes)

1. $100 \%=1998$

2. $85 \%=2001$ (inflection point)

3. $0 \%=2004$

C. Minimize schedule impacts to other projects

1. Project $W-030$ high-heat waste vent system, move/replace AZ-101 large condenser to service another AWT

a. Months of project delay, 0 to 12 , linear scale 
VII. Minimize Cost, independent variable, not part of value system, Appendix A

A. Project cost

B. Operating cost

C. Expense cost profile by year

\subsection{REQUIREMENTS LISTING}

The following requirements or "needs" were 1 isted in order to make a preliminary sorting of the viable alternatives. Requirements are defined as the minimum specifications the alternatives must meet. The alternatives were discarded in the initial screening if they did not meet the requirements. The exception to this was Alternative Oa, "Do Nothing" approach, which was further evaluated in order to develop a baseline for tank waste volume comparisons. The requirements were taken from the F\&R document (DOE-RL 1993) genera1 headings and brainstormed in team meetings.

\section{Requirements:}

1. Maintain spare AUT space, i.e., 3,800 to $3,800,000 \mathrm{~L}(1,000$ to 1 million gal) in savings more than the nonconsolidation ("Do Nothing") case.

2. No unacceptable safety analys is report (SAR) events

3. No tank bumps

4. Meet Tri-Party Agreement milestones. The major milestone of interest is tank C-106 retrieval by 0ctober 1997.

The rationale in determining Requirement 1 was to avoid building new tanks. The waste volume projections call for $3,800,000 \mathrm{~L}$ (1 million gal) of tank space to be provided from consolidation, so the requirement was set that the alternative had to provide more tank space than the "Do Nothing" approach (ATternative 0a).

Requirement 3 may be part of Requirement 2. The major unacceptable SAR event that concerned team members was the tank bump event. Consolidation of high-heat waste tends to set up the conditions for a tank bump. The tank bump event may be an acceptable accident in the SAR now but may not remain so with increased sludge volume. Therefore, the tank bump issue was specifically called out. To mitigate the tank bump, it was decided that mixer pumps would always be available in the tank in which the sludge was consolidated (when heat or sludge height was greater than existing limits, proposed Project $W-320$ or IOSR limits). Mixing the sludge with the redundant mixer pumps would avoid" the tank bump as well as ignitable gas issues.

Requirement 4 is to meet the Tri-Party Agreement milestones which are legally binding, and those that are listed but may not be legally binding. It was assumed that a good faith effort to meet all milestones would be made, and that the Hanford Site would come very close to meeting them. If an alternative caused a non-legally binding milestone date to be missed by a relatively small amount of time, then the alternative proceeded to the final selection evaluation. 
WHC-SD-WM-ER-532

Revision 0

\subsection{ALTERUATIVES}

The preliminary alternatives are listed below and described in terms of solid waste transfers. The shorthand version of the transfers is 1 isted after the alternative number. Normally, when solids are transferred it is assumed that mixer pumps are installed in the initiating tank. The exception is the "bottom solids transfer" using C-106 solids settling into AY-102 and transferring the settling solids to the next tank. This is usually done using only the existing transfer pump in AY-102.

Unless noted otherwise, the preliminary transfer scenarios refer to solids, not to supernate. The supernate transfers were not thought to be critical in this first evaluation. The following preliminary process scenarios were brainstormed; the first two are expanded from the shorthand version to assist the reader:

A. Do Nothing - Transfer C-106 Slurry to (\) AY-102

The supernate in AZ-102 would be concentrated from $2.3 \mathrm{M}$ sodium to $5 \mathrm{M}$ sodium. The AY tanks also would store waste at $5 M$ sodium because they contain high-heat solids. This alternative was kept as a comparison case although it would normally be rejected due to Requirement 1.

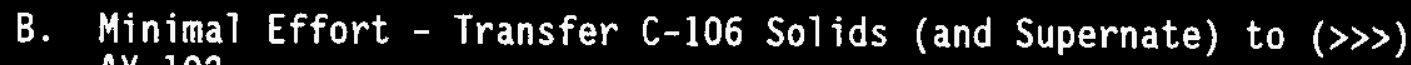
AY -102

Concentrate high-heat supernate from $A Z-101$ and $A Z-102$ in $A Y-101$ to $7 M$ sodium from their respective $5 M$ and $2.3 M$ sodium values. This will allow concentration of about $6,800,000 \mathrm{~L}(1.8 \mathrm{million}$ gal) of supernate into the 3.59 million $L(0.95$ million gal) available in tank AY-101.

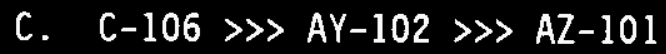

Bottom slurry transfer from AY-102 to AZ-101.

D. Planning Case (Bacon 1995)

$C-106 \gg A Y-102 \gg A Z-102$ (bottom slurry transfer $A Y-102$ to $A Z-102$ ) $A Z-101 \gg A Z-102$

E. $C-106 \gg A Y-102 \gg A Z-102$ (bottom slurry transfer $A Y-10$ ? to $A Z-102$ )

$A Z-101 \gg A Z-102$

$A Y-101 \gg A Z-102$

and/or AY-102 $\gg A Z-102$ (mixer pump installed in AY-102)

F. C-106 $\gg$ non-AWTs (split solids)

This scenario modifies Project $W-320$ by splitting the solids from C-106 to go to two separate non-AWTs (AN-106 and AN-104). The pipeline would be changed by turning a valve or changing a jumper at a new or existing diversion box near one of the DSTs. Modification of the design and installation of the transfer line and diversion box would delay the project causing the transfer to be initiated after the Tri-Party Agreement start date of October 1997. Rejected due to Requirement 4. 
WHC-SD-WM-ER-532

Revision 0

G. $\quad C-106 \gg A Z-102$

$A Z-101 \gg A Z-102$

Reroute Project $\mathrm{W}-320$ pipelines to $\mathrm{AZ}-102$.

H. $\quad C-106 \gg$ AY -101

Rejected due to delay of the C-106 Tri-Party Agreement Milestone date, Requirement 4. By the time required missing waste composition information on AY-101 were gathered and the project completed, the C-106 milestone deadline would be exceeded. All consolidation of high-heat sludge to AY-101 requires sampling of the sludge in AY102 .

I. $\quad C-106 \gg \mathrm{AZ}-101$

Reroute Project $\mathrm{W}-320$ new waste pipeline from $\mathrm{C}-106$ to $\mathrm{AZ}-101$.

J. $C-106 \gg \mathrm{AZ}-102$

Reroute Project $\mathrm{W}-320$ pipeline from $\mathrm{C}-106$ to $\mathrm{AZ}-102$.

K. $\quad C-106 \gg$ AZ-102

$A Z-101 \gg A Z-102$

Concentrate supernate in AY-102; do not include potentially complexed supernate from AY-101.

L. $\quad C-106 \gg$ AY-102 $\gg$ non-AWTs

Rejected due to high-heat solids causing: (1) tank bump, Requirement 4, and/or (2) loss of tank storage space, Requirement 1.

M. $C-106 \gg$ AZ -101

$A Y-102 \gg$ AZ -101

$A Y-101 \gg A Z-101$

$A Z-102 \gg$ AZ-101

Concentrate supernate in non-AZ-101 tank (or supernate $\gg$ non-AWT).

Not optimum scenarios. See Alternative E for a better consolidation alternative requiring less rerouting of 1 ines and better timing.

N. Do not retrieve $\mathrm{C}-106$. Continue with process and mixer pump testing. Consolidate NCAN solids into one AWT. Rejected due to Requirement 4--does not meet Tri-Party Agreement, and Requrirement 2, unacceptable safety concern.

0 . Consolidate NCAW solids then transfer $\mathrm{C}-106$ solids to AWT. Rejected due to Requirement 4. The timing required to install mixer pumps would miss the Tri-Party Agreement milestone by years, and would also continue the safety concern of high-heat waste in $\mathrm{C}-106$. 
WHC-SD-WM-ER-532

Revision 0

P. Consolidate all high-heat and C-106 solids into one AWT (Alternative $M$ and/or different consolidation tank). Consolidate AZ-101 and AZ-102 supernate into the consolidated sludge tank. Rejected due to large tank bump potential (800 KBtu/h and $1,122 \mathrm{~cm}$ [442 in.] of solids) even though mixer pump(s) are installed, Requirement 3.

\subsection{INITIAL SCREENING OF ALTERNATIVES}

Eleven alternatives designated $0 a, 0 b, 1 a, 1 b, 2,3,4,5 a, 5 b, 5 c$, and 6 were initially chosen for continued analys is from the above preliminary alternatives. The reasons that the preliminary alternatives were screened out are given below their description in Section 3.3. This selection of alternatives was designed to analyze the strengths and weaknesses of the general processing scenarios and thus exemplify the major trade-offs. The initial analysis used caustic leaching and water washing on all the retrieved sludges except $A Z-101$. The solids in AZ-101 would not benefit from caustic leaching.

After the initial analysis, it was found that only $\mathrm{C}-106$ sludge might need to be caustic leached (Vienna and Hrma 1995). Therefore, the scenarios that retained caustic leaching were optimized to caustic leach only solids from $\mathrm{C}-106$. This reduced the total amount of caustic leaching and improved the scores (value) of those alternatives that contained caustic leach.

\subsubsection{Screening of Alternatives}

After the initial evaluation was performed, eight more alternatives were included which did not include any special leaching and washing in their operations. The letter "N" was added before the modified alternative and stood for "no special leaching or washing," and the leaching and washing steps were removed from those alternatives. Otherwise, the "N" alternatives were the same as the non- "N" alternatives. These non-leach alternatives were designated $\mathrm{N} 1 \mathrm{a}, \mathrm{N1b}, \mathrm{N} 3, \mathrm{~N} 4, \mathrm{~N} 5 \mathrm{a}, \mathrm{N} 5 \mathrm{~b}, \mathrm{~N} 5 \mathrm{c}$, and $\mathrm{N} 6$. One alternative (7a) was added during group analysis and brainstorming to attempt to optimize all the scenarios, and another alternative (7b) was later added to confirm that in-tank concentration of AZ-102 aging waste supernate would be preferable to concentration at the 242-A evaporator.

\subsubsection{Sumary of Transfers and Analyses}

3.5.2.1 Alternative Assumptions. This section contains the major assumptions for transfer of sludge and supernate in the alternatives.

- All the alternatives (except $0 \mathrm{a}$ ) include an option to fill the consolidated solids tank with concentrated $7 \mathrm{M} \mathrm{Na} l i q u i d$, which will tend to recontaminate clean (washed) solids for final vitrification. This step is envisioned to be the last resort to make tank space or if leaching and washing of the sludge did not need to be performed. 
- All the scenarios (except 0 a) consolidate high-heat supernate from $A Z-101$ and $A Z-102$ in one AWT. The tank chosen for supernate consolidation was normally the tank that had the lowest amount of heat content in the sludge. This reduces the likelihood of a tank bump in the tank with the high-heat supernate. The supernate tank usually carried an insignificant risk of heating up the sludge to form enough steam to cause a tank bump.

- Reducing the heat load in C-106 is one goal of Project W-320 (Bailey 1995). Whenever $\mathrm{C}-106$ solids are transferred to $\mathrm{AY}-102$, $<40,000 \mathrm{Btu} / \mathrm{h}(36 \%$ of the heat $10 \mathrm{ad})$ should remain in $\mathrm{C}-106$. This is about $130 \mathrm{Kgal}$ of solids transferred to AY-102, assuming heat and mass ratios are equal. For final configuration of mass balances, the following Tri-Party Agreement milestones relating to $\mathrm{C}-106$ were considered:

- Milestone M-45-T01, "Complete SST waste retrieval demonstration" in September 2003. Initiate and complete a ful1-scale demonstration of SST retrieval technology. This demonstration will be considered complete when $<99 \%$ of the waste inventory is removed from an SST. (This would be about $(9,080 \mathrm{~L}[2,400 \mathrm{gal}]$ remaining in C-106 [Harris 1995]).

- Milestone M-45-03-T02, "Initiate final retrieval demonstration of $\mathrm{C}-106$ " in June 2002. "Initiate final retrieval of tank 241-C-106 to complete initial demonstration of SST retrieval technologies."

- For final configuration (FY 2004) of tank C-106, it has been assumed that $99 \%$ of its solids have been transferred to AY-102 or other appropriate receiver tank, depending on the alternative. It was further assumed that the $99 \%$ cleanout of $\mathrm{C}-106$ would occur in time to qualify for any leaching and washing called out in the alternatives. See Table 3-1 for general retrieval assumptions.

Table 3-1. Percent Sludge Retrieved From Tanks.

\begin{tabular}{|l|c|c|c|c|c|}
\hline & \multicolumn{5}{|c|}{ Tanks } \\
\cline { 2 - 6 } & AZ-101 & AZ-102 & AY-101* & AY-102* & C-106 \\
\hline $\begin{array}{l}\text { Percent sludge retrieved with } \\
\text { large mixers (C-106 uses } \\
\text { Project W-320 sluicing } \\
\text { system) }\end{array}$ & 95 & 95 & 99 & 99 & 75 \\
\hline $\begin{array}{l}\text { Percent sludge retrieved from } \\
\text { C-106 final cleanout } \\
\text { demonstration, FY 2003 }\end{array}$ & - & -- & -- & -- & 99 \\
\hline
\end{tabular}

*Tanks $A Z-101$ and $A Z-102$ are assumed to have two 250-hp mixer pumps and two 300-hp mixer pumps, respectively. AY tanks are assumed to have four 250-hp mixer pumps.

$$
F Y=F i s c a l \text { year }
$$


- When C-106 solids are transferred by bottom sludge transfer (defined as a transfer of a settling slurry using only the AY-102 transfer pump) from AY-102 to other tanks, $50 \%$ of the C-106 solids are transferred. None of the solids in AY-102 are transferred. When a 75-hp rotating mixer pump is installed in $A Y-102$, replacing the existing inoperable pump, it is assumed that $90 \%$ of the $\mathrm{C}-106$ solids are transferred to the next tank and 25\% of the solids in AY-102 are transferred as shown in Table 3-2.

Table 3-2. Percent Sludge Retrieved from AY-102, With and Without 75-hp Mixer Pump.

\begin{tabular}{|l|c|c|}
\hline & \multicolumn{2}{|c|}{ Tanks } \\
\cline { 2 - 3 } & AY-102 & C-106 \\
\hline $\begin{array}{l}\text { Percent sludge retrieved from } \\
\text { AY-102 not using 75-hp mixer }\end{array}$ & 0 & 50 \\
\hline $\begin{array}{l}\text { Percent sludge retrieved from } \\
\text { AY-102 using 75-hp mixer* }\end{array}$ & 25 & 90 \\
\hline
\end{tabular}

*A rotating 75-hp mixer pump is assumed to be a replacement for the existing unit in AY-102.

- The year 2004 was used as the end point for this study because all solids consolidation activities from all scenarios could be completed by then. This is also well in advance of the tank space shortage that is expected in FY 2006 (Koreski and Strode 1995).

- The $5 M$ or $7 M$ Na waste supernate used to fill tanks or supplement in-tank concentration efforts is assumed to be a low-heat, clear, convective liquid that comes from the 242-A evaporator. This will be non-complexed waste. Waste at $7 \mathrm{M}$ Na was chosen to be put on top of aging waste solids because it is generally considered to be free of precipitates and can produce a clean, convective 1iquid (Powell 1995).

- Sludge transfer ratios average 3-to-1 water-to-sludge by volume, as assumed by Koreski and Strode (1995).

- Washing of consolidated sludge takes about five times as much water as the volume of sludge it cleans (MacLean and Powell 1995). When available, washing of sludge is performed twice. Slurry transport can perform sludge washing if dilute liquid waste is used.

- Caustic washing of sludge requires a volume of $50 \%$ sodium hydroxide equal to $82 \%$ of the volume of consolidated sludge (Maclean 1995) for C-106. Of all the sludge in AWTs, it is anticipated that only C-106 sludge may need to be caustic leached to lower waste vitrification product volumes. In Alternatives $1 \mathrm{a}, 1 \mathrm{~b}, 3,4,5$ (al1), and 6, one caustic leach is performed on $\mathrm{C}-106$ solids when mixer pumps are 
WHC-SD-WM-ER-532

Revision 0

available; this may entail leaches on portions of $C-106$ waste. No caustic leaching is performed in the other alternatives.

- Sodium hydroxide has a specific gravity of 1.35 at $32 \%$ and $0{ }^{\circ} \mathrm{C}$ $\left(32{ }^{\circ} \mathrm{F}\right)$. The sodium hydroxide was assumed to be diluted before reaching the tank, from $50 \%$ to $32 \%$, or about $60 \%$ dilution to ensure that the data quality objective specific gravity limit of 1.35 was adhered to.

In the transfer summary section below, the volume of slurry is estimated to the nearest $50,000 \mathrm{gal}$.

3.5.2.2 Alternatives. The main alternatives that passed the initial screening are 1 isted below. They contain all the transfers anticipated to be encountered in the operation of the alternatives. Also listed are approximate volumes of the transfers as well as source and destination of the transfers.

These transfer scenarios have been optimized as far as possible in the time available. There may be minor improvements possible to reduce or delete some transfers. Minor changes are not anticipated to alter the score of the alternative. All alternatives include the following transfers to start the process:

\section{Transfers/activities}

1. AY-101 supernate to AP Tank Farm

2. AZ-101 supernate to AY-101
Comments

Routine, $850 \mathrm{Kgal}$

Rout ine (6 Ci/gal cesium-137, typical), $900 \mathrm{Kgal}$

0a. "Do Nothing"

C-106 (solids) $\gg$ AY-102

The solutions in the AWTs are concentrated to $5 \mathrm{M} \mathrm{Na}$ after the solids from C-106 are transferred to AY-102. Waste in AZ-102 is concentrated in-tank to obtain supernate at $5 \mathrm{~N} \mathrm{Na}$. Waste concentrated to $5 \mathrm{M} \mathrm{Na}$ is added to AY-102 from the evaporator. Evaporated waste is sent to AZ-102 as tank space becomes available in $A Z-102$. This in-tank concentration is performed with $A Z-102$ supernate, taking 3.5 to 4 years to complete. When space is available and after AY-101 is no longer needed as a receiver, dilute waste is concentrated to $5 M \mathrm{Na}$ at the evaporator and transferred to $\mathrm{AY}-101$.

\section{Iransfers/activities}

3. AY-102 supernate to $A Z-101$

for process test using W-151 mixers

4. Transfer $C-106$ to $A Y-102$

5. Supernate in $A Z-101$ to AW Tank Farm for concentration

6. High-heat supernate in AY-101 to $A Z-101$

7. Concentrated $5 \mathrm{~N} \mathrm{Na}$ from AW Tank Farm to AY-102 (as required)
Comments

\author{
Routine $750 \mathrm{Kgal}$ \\ $800 \mathrm{Kgal}$ slurry transfer \\ Routine, $750 \mathrm{Kgal}$ \\ Routine, $900 \mathrm{Kgal}$ \\ Routine, $900 \mathrm{Kgal}$
}


8. Concentrated $5 M \mathrm{Na}$ from AW Tank

Farm to AZ-102 (as required as

in-tank concentration continues*) Two routine, $200 \mathrm{Kgal}$ each

9. Concentrated $5 M \mathrm{Na}$ from AW Tank

Farm to AY-101
Routine, $850 \mathrm{Kga}]$

*The tank containing AZ-102 supernate will slowly (during 3.5 to 4 years) condense $400 \mathrm{Kgal}$ of condensate to $\mathrm{AZ}-151$. This condensate will be transferred to the aging waste dilute receiver tank, probably AY-101.

\section{ob. "Minimal Effort" \\ C-106 > AY-102}

Supernate in the AWTs is concentrated to $7 \mathrm{M} \mathrm{Na}$ after the solids from C-106 are transferred to AY-102. Waste in AZ-101 and AZ-102 is concentrated in-tank to obtain supernate at $7 \mathrm{M} \mathrm{Na}$. Waste concentrated to $7 \mathrm{M} \mathrm{Na}$ is added to AZ-101, AZ-102, AY-101, and lastly to AY-102 as tank space becomes available and volume constraints dictate. This in-tank concentration takes about 1.5 years for $A Z-101$ supernate (in tank $A Z-101$ ) and 5 to 6 years for $A Z-102$ supernate (in tank AZ-102). The AY-101 tank supernate is transferred out after the tank is no longer needed as a dilute receiver. Then dilute waste is concentrated to $7 \mathrm{M} \mathrm{Na}$ at the evaporator and transferred to AY-101. The $7 \mathrm{M} \mathrm{Na}$ solution is equal to clean, convective solids and probably would require the equivalent of a minor USQ to delete the $5 \mathrm{~N} \mathrm{Na}$ OSD limit for supernate stored above aging waste solids.

\section{Iransfers/activities}

3. AY-102 supernate to $A Z-101$ for process test

4. Transfer $\mathrm{C}-106$ to AY-102

5. AZ-101 supernate to AW Tank Farm for concentration

6. High-heat AY-101 supernate back to $A Z-101$, in-tank concentration continues to $7 \mathrm{M} \mathrm{Na}$ *

7. AW Tank Farm concentrated $7 \mathrm{M} \mathrm{Na}$ waste to $A Z-101$, as required*

8. Concentrated $7 \mathrm{M} \mathrm{Na}$ from AM Tank Farm to AY-102

9. Concentrated $7 \mathrm{M} \mathrm{Na}$ from AW Tank Farm to AZ-102 (as required, and in-tank concentration cont inues*)

10. Concentrated $7 M \mathrm{Na}$ from AW Tank Farm to AY-101

\section{Comments}

Routine, $750 \mathrm{Kga}]$

$800 \mathrm{Kgal}$ slurry transfer

Routine, $750 \mathrm{Kga} 1$ each

Process test on 5M Na limit, sample boil down, $900 \mathrm{Kgal}$

Routine, $250 \mathrm{Kgal}$

$900 \mathrm{Kgal}$

Two transfers probable, $250 \mathrm{Kgal}$ each

\section{$850 \mathrm{Kgal}$}

*The tank containing the original AZ-101 supernate will transfer (in 1 to 2 years) $250 \mathrm{Kgal}$ of condensate to $A Z-151$ and to the aging waste dilute receiver tank. The tank containing AZ-102 supernate will slowly (5 to 6 years) transfer $500 \mathrm{Kgal}$ of condensate to $A Z-151$ and to a dilute receiver AWT, probably AY-101. 
1a. "Pipel ine Reroute to AZ-101"

C-106 (solids) $\gg \gg>A Z-101$ (Project U-320 pipelines rerouted to AZ-101) (store high-heat supernate in AY-102)

\section{Transfers/activities}

3. AY-102 supernate to $A Z-101$ for AZ-101 process test

4. AZ-101 supernate back to AY-102

5. C-106 solids to $A Z-101$

6. AZ-102 supernate to AN Tank Farm for evaporation

7. High-heat AZ-101 supernate in AY-101 to AY-102 (in-tank concentration to $8 \mathrm{Ci} / \mathrm{gal}$ cesium-137, typical*)

8. High-heat AZ-102 evaporated supernate from AW Tank Farm to AY-102 at $12 \mathrm{Ci} / \mathrm{gal}$ cesium-137 (typical)

9. $7 \mathrm{M} \mathrm{Na}$ to $\mathrm{AZ}-102$

10. Double-she11 slurry feed (DSSF) to AY-101

11. Leach and wash AZ-101 supernate to AP or AW Tank Farm, retain last wash.

\section{Comments}

Routine, $750 \mathrm{Kgal}$

Routine, $750 \mathrm{Kgal}$

gers Kgal slurry transfer

Two transfers at $4 \mathrm{Ci} / \mathrm{gal}$

cesium-137, $420 \mathrm{Kgal} / \mathrm{each}$

Routine, $850 \mathrm{Kga} 1$

Two transfers, $140 \mathrm{Kgal} /$ each $500 \mathrm{Kgal}$

$950 \mathrm{Kgal}$ at specific gravity limit

Five liquid transfers, one caustic in at $250 \mathrm{Kgal}(32 \%$ sodium hydroxide) and one out at $250 \mathrm{Kgal}$, two dilute liquid in at $800 \mathrm{Kgal}$, one dilute liquid out at $800 \mathrm{Kgal}$

*The tank containing the original AZ-101 superinate will slowly (in 1 to 2 years) transfer at least $250 \mathrm{Kgal}$ of condensate to AZ-151 and from there to the aging waste dilute receiver tank.

1b. "AZ-101 Reroute \& Consolidate"

C-106 (solids) $\gg \gg>~ N Z-101$

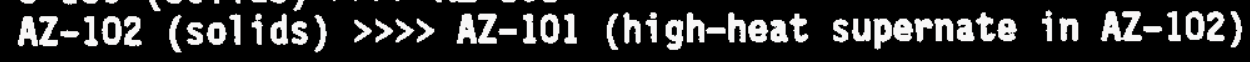

Changes to 1a are shown below:

\section{Transfers/activities}

7. Wash AZ-102, to AP Tank Farm

\section{Comments}

Three routine transfers, two dilute washes in of $300 \mathrm{Kgal}$ each, one dilute wash out 
8. Caustic leach and wash AZ-101 and $C-106$ solids, supernate to AP Tank Farm

9. $A Z-102$ solids to $A Z-101$

10. High-heat AY-101 concentrated supernate to $A Z-102$, in-tank concentration*

11. High-heat concentrated supernate from AW Tank Farm to $A Z-102$ at $12 \mathrm{Ci} / g a l$ cesium-137 (typical)

12. $7 M$ Na to $A Y-101$

13. $7 \mathrm{M} \mathrm{Na}$ to $\mathrm{AY}-102$
Four routine transfers, one caustic transfer of $400 \mathrm{Kgal} 7 \mathrm{M}$ $\mathrm{NaOH}$ in from 204-AR, one high sodium transfer out of $400 \mathrm{Kgal}$, one dilute wash in of $500 \mathrm{Kgal}$, one dilute wash out of $100 \mathrm{Kgal}$ Ore slurry transfer of $400 \mathrm{Kgal}$

One supernate transfer of $<800 \mathrm{Kgal}$

Two supernate transfers of $150 \mathrm{Kgal}$ each

$850 \mathrm{Kgal}$

$800 \mathrm{Kga} 1$

*About $250 \mathrm{Kgal}$ of $(A Z-101)$ high-heat supernate condensate will be transfered (in a 1 to 2 year period) to $A Z-151$ and from there to the aging waste dilute receiver tank.

\section{2. "Minimal Case - Evaporator Concentrate" C-106 (solids) $\gg$ AY-102 \\ (high-heat supernate to AY-101)}

This alternative uses the 242-A evaporator to concentrate AZ-102 supernate to $7 \mathrm{M} \mathrm{Na}$ instead of in-tank evaporation as done in Alternative $0 \mathrm{~b}$. Alternative 2 does not include mixer pumps in AY-102 so no further washing and leaching can be performed until mixer pumps are available.

\section{Iransfers/activities}

3. AY-102 supernate to AZ-101 for process test

4. Transfer $\mathrm{C}-106$ to AY-102

5. AZ-102 supernate to AW Tank Farm for concentration

6. AW Tank Farm AZ-102 concentrated high-heat supernate to $A Y-101$ at $12 \mathrm{Ci} / \mathrm{gal}$ cesium-137 (typical)*

7. $7 M$ Na to $A Z-102$

8. $7 M \mathrm{Na}$ to $\mathrm{AZ}-101$

\section{Comments}

Routine $750 \mathrm{Kgal}$ $800 \mathrm{Kgal}$ slurry transfer

Two transfers at $4 \mathrm{Ci} / \mathrm{gal}$ cesium-137, $450 \mathrm{Kgal}$ each

Two transfers, $150 \mathrm{Kgal}$ each $900 \mathrm{Kgal}$

$900 \mathrm{Kgal}$

*About $250 \mathrm{Kgal}$ of (AZ-101) high-heat supernate condensate will be transfered (in a 1 to 2 year period) to $A Z-151$ and from there to the aging waste dilute receiver tank. 
3. "Bottom Slurry Transfer (Decant) to AZ-101"

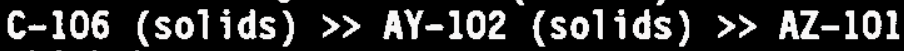
(high-heat supernate to AZ-102)

Transfers/activities

3. AY-102 supernate to $A Z-101$ for process test

4. AZ-101 supernate to AW Tank Farm

5. $C-106$ transfer to $A Z-101$ via AY -102

6. Caustic leach and wash AZ-101, keep last supernate

7. High-heat $A Z-102$ supernate to AW Tank Farm for evaporation

8. High-heat $A Z-101$ supernate in $A Y-101$ to $A Z-102$, continue intank concentration*

9. AW Tank Farm AZ-102 concentrated supernate to $A Z-102$ at $12 \mathrm{Ci} / \mathrm{gal}$ cesium-137 (typical)

10. $7 M \mathrm{Na}$ concentrate from AW Tank Farm to $A Y-101$

11. $7 M$ Na concentrate from AW Tank Farm to AY-102

\section{Comments}

Rout ine $750 \mathrm{Kgal}$

Routine $750 \mathrm{Kgal}$

$800 \mathrm{Kgal}$ slurry transfer to AY-102 (may be recycled to C-106), $600 \mathrm{Kgal}$ bottom decant slurry transfer from AY-102 to AZ-101

Five transfers, one caustic in at $100 \mathrm{Kgal}$, one caustic out at $100 \mathrm{Kgal}$, two dilute 1 iquid in at $300 \mathrm{Kgal}$, one dilute liquid out at $300 \mathrm{Kgal}$

Two transfers at $4 \mathrm{Ci} / \mathrm{gal}$ cesium-137, $450 \mathrm{Kgal}$ each

Routine $800 \mathrm{Kgal}$

Two transfers at $150 \mathrm{Kgal}$ each $850 \mathrm{Kgal}$

$850 \mathrm{Kgal}$

*About $250 \mathrm{Kgal}$ of (AZ-101) high-heat supernate condensate will be transfered (in a 1 to 2 year period) to $A Z-151$ and from there to the aging waste dilute receiver tank.

4. "Reroute and Consolidate to AZ-102" C-106 (solids) $\gg \gg \gg$ AZ-102

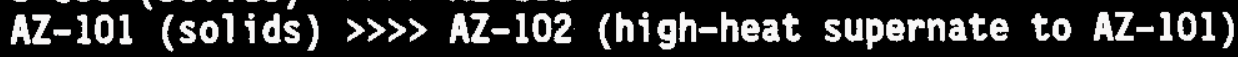

\section{Iransfers/activities}

3. AY-102 to $A Z-101$ for process test

4. AZ-102 supernate transfer to AW Tank Farm for concentration

5. C-106 directly to AZ-102

\section{Comments}

Routine $750 \mathrm{Kgal}$

Two transfers at $4 \mathrm{Ci} / g a 1$ cesium-137, $450 \mathrm{Kgal}$ each $800 \mathrm{Kgal}$ slurry transfer 
6. Caustic leach and wash $A Z-102$ supernate to AP Tank Farm

7. Wash AZ-101 supernate to AP Tank Farm, retain last wash

8. Transfer $A Z-101$ solids to $A Z-102$

9. High-heat supernate in AY -101 to $A Z-101$ *

10. Concentrated AZ-102 supernate from $A W$ Tank Farm to $A Z-101$ at $12 \mathrm{Ci} / \mathrm{gal}$ cesium-137 (typical)

11. AY-102 supernate to AP Tank Farm

12. DSSF from AW Tank Farm to AY-102

13. $7 \mathrm{M} \mathrm{Na}$ from AW Tank Farm to AY-101
Six routine transfers, one out at $500 \mathrm{Kgal}$, one caustic in at

$250 \mathrm{Kgal}$, one high sodium out at

$250 \mathrm{Kgal}$, two washes in at

$800 \mathrm{Kgal}$, one wash out at

$800 \mathrm{Kgal}$

Three transfers, two dilute washes in at $200 \mathrm{Kgal}$, one wash out at $200 \mathrm{Kgal}$

$250 \mathrm{Kgal}$

Routine, $800 \mathrm{Kgal}$

Two transfers at $150 \mathrm{Kgal}$ each Rout ine, $700 \mathrm{Kgal}$

$900 \mathrm{Kgal}$

$850 \mathrm{Kgal}$

*About $250 \mathrm{Kgal}$ of $(A Z-101)$ high-heat supernate condensate will be transfered (in a 1 to 2 year period) to $A Z-151$ and from there to the aging waste dilute receiver tank.

5a. "planning Case" (Bacon 1995)

AZ-101 (solids) $\gg$ AZ-102

C-106 (solids) $\gg$ AY-102 (C-106 [solids]) $\gg A Z-101$ (solids) $\gg A Z-102$ (high-heat supernate in AZ-101)

\section{Transfers/activities}

3. AY-102 supernate to $A Z-101$

4. AZ-102 supernate to AW Tank Farm for evaporation

5. $A Z-101$ solids to $A Z-102$

6. $\mathrm{C}-106$ solids to $\mathrm{AZ}-101$ via $\mathrm{AY}-102$

7. Caustic leach and wash AZ-101, supernate to AP Tank Farm, retain last wash 1 iquid

8. Wash AZ-102 supernate to AP Tank

\section{Comments}

Routine $750 \mathrm{Kgal}$

Two transfers at $4 \mathrm{Ci} / \mathrm{gal}$ cesium-137, $450 \mathrm{Kgal}$ each Two transfers, $800 \mathrm{Kgal} 1$ iquid and solids to $A Z-102$

$800 \mathrm{Kgal}$ slurry transfer to AY-102 (may be recycled to $\mathrm{C}-106), 600 \mathrm{Kgal}$ bottom decant slurry transfer from AY-102 to AZ-101

Five routine, one caustic in at $100 \mathrm{Kgal}$ from 204-AR, one caustic out at $100 \mathrm{Kgal}$, two dilute liquid in at $500 \mathrm{Kgal}$, one dilute 1 iquid out at $500 \mathrm{Kgal}$ 
Farm

9. $A Z-101$ solids to $A Z-102$

10. AY-101 high-heat supernate to $A Z-101$, cont inue in-tank concentration*

11. AW Tank Farm (concentrated AZ-102 supernate) to $A Z-101$ at $12 \mathrm{Ci} / \mathrm{gal}$ cesium-137 (typical)

12. DSSF to AY-102

13. DSSF to AY-101
Four routine, two dilute liquid in at $500 \mathrm{Kgal}$ each, two dilute 1 iquid out at $500 \mathrm{Kgal}$ each $600 \mathrm{Kgal}$ slurry transfer

Routine, $700 \mathrm{Kgal}$

Two transfers, $150 \mathrm{Kgal}$ each $850 \mathrm{Kgal}$

$950 \mathrm{Kgal}$

*About $250 \mathrm{Kgal}$ of (AZ-101) high-heat supernate condensate will be transfered (in a 1 to 2 year period) to AZ-151 and from there to the aging waste dilute receiver tank.

5b. "AY-102 Consolidation"

$A Z-101$ (solids) $\gg>A Z-102$

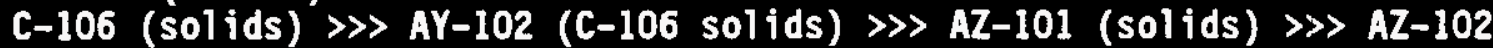

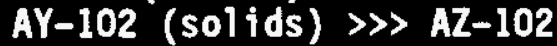

Change Alternative 5a starting with the following steps:

\section{Transfers/activities}

12. Decant $A Z-102$ supernate to AW Tank Farm for concentration

13. Leach and wash AY-102 supernate to and from AP Tank Farm and 204-AR, retain last wash

14. AY-102 solids to AZ-102

15. $7 M$ Na to $A Y-102$

16. DSSF to AY-101

\section{Comments}

Routine, $500 \mathrm{Kga}]$

Five routine, one caustic in at $100 \mathrm{Kgal}$ from 204-AR, one caustic out at $100 \mathrm{Kgal}$, two dilute liquid in at $500 \mathrm{Kgal}$, one dilute liquid out at $500 \mathrm{Kgal}$ $600 \mathrm{Kgal}$

Routine, $950 \mathrm{Kgal}$

$900 \mathrm{Kgal}$

5c. "AY-101 Consolidation"

AZ-101 (solids) \> AZ-102

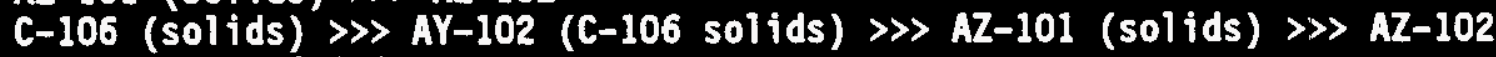

AY-101 $\gg \gg$ AZ-102

Change Alternative 5a starting with the following steps:

\section{Transfers/activities}

12. Decant $A Z-102$ supernate to

AW Tank Farm for concentration

13. Wash AY-101 supernate to
Comments

Routine, $500 \mathrm{Kgal}$ 
AP Tank farm, retain last wash

14. AY-101 solids to $A Z-102$

15. DSSF to $A Y-102$

16. DSSF to $A Y-101$
Three routine, two in at $400 \mathrm{Kgal}$, one out at $400 \mathrm{Kgal}$ $500 \mathrm{Kga} 1$ $850 \mathrm{Kga} 1$ Routine, $950 \mathrm{Kgal}$

Note: Sludge sampling required in AY-101.

\section{6. "U1timate Consolidation"}

AZ-101 (solids) $\gg$ AZ-102

C-106 (solids) $\gg$ AY-102 (C-106 solids) $\gg A Z-101$ (solids) $\gg$ AZ-102 $A Y-101$ (s) $\gg A Y-102$ (s) $\gg A Z-102$

Alternative 6 transfers all aging waste solids into $A Z-102$. It is the same as Alternative 5 a with the following changes:

\section{Transfers/activities}

12. Dilute waste from AP to $A Y-101$

13. AY-101 solids to AY-102

14. Leach and wash AY-102 supernate to AP Tank Farm, retain last wash

15. AY-102 solids to $A Z-102$

16. DSSF to $A Y-102$

17. DSSF to AY-101

\section{Comments}

Routine, $400 \mathrm{Kgal}$, first wash Minor USQ evaluation, $500 \mathrm{Kgal}$ Six routine, one caustic in at $100 \mathrm{Kgal}$, one caustic out at $100 \mathrm{Kgal}$, two wash in at $750 \mathrm{Kgal}$, two wash out at $750 \mathrm{Kgal}$, and $150 \mathrm{Kgal}$ Possible safety assessment $800 \mathrm{Kga} 1$ Routine, $950 \mathrm{Kgal}$ Routine, $950 \mathrm{Kgal}$

Note: One possible safety assessment required; sludge sampling required in $A Y-101$.

\section{7. "75-Hp Mixer Pump" \\ C-106 (solids) $\gg$ AY-102 (solids) $\gg$ AZ-101 (high-heat supernate to $A 2-102$ )}

This alternative is the same as Alternative 3 except that the existing 75-hp mixer pump in AY-102 is removed and replaced. Then $90 \%$ of the $C-106$ sludge is assumed to be transferred to $A Z-101$ from $A Y-102$, and $25 \%$ of the AY-102 sludge to AZ-101. These transfer distributions are based on process knowledge. Caustic leaching is not performed.

\section{Iransfers/activities}

3. AY-102 supernate to $A Z-101$ for process test

4. AZ-101 supernate to AW Tank Farm

5. C-106 transfer to $A Z-101$ via AY -102 , first wash $C-106$ sludge

\section{Comments}

Routine $750 \mathrm{Kgal}$

Routine $750 \mathrm{Kgal}$

$800 \mathrm{Kgal}$ slurry transfer to AY-102 (may be recycled to 
WHC-SD-WM-ER-532

Revision 0

6. High-heat $\mathrm{AZ}-102$ supernate to AW Tank Farm for evaporation

C-106), $600 \mathrm{Kgal}$ 75-hp mixer pump slurry transfer from AY-102 to AZ-101

Two transfers at $4 \mathrm{Ci} / \mathrm{ga}]$ cesium-137, $450 \mathrm{Kgal}$ each

7. High-heat $A Z-101$ supernate in $A Y-101$ to AZ-102, continue in-tank concentration*

8. AW Tank Farm AZ-102 concentrated supernate to $A Z-102$ at

$12 \mathrm{Ci} / \mathrm{gal}$ cesium-137 (typical)

9. $7 \mathrm{H}$ Na concentrate from AW Tank Farm to AY-101

10. $7 M \mathrm{Na}$ concentrate from AW Tank Farm to $A Y-102$

Routine $800 \mathrm{Kgal}$

Two transfers at $150 \mathrm{Kgal}$ each

$850 \mathrm{Kgal}$

$950 \mathrm{Kgal}$

*About $250 \mathrm{Kgal}$ of $(A Z-101)$ high-heat supernate condensate will be transfered (in a 1 to 2 year period) to $A Z-151$ and from there to the aging waste dilute receiver tank.

The remaining alternatives (N1a, N1b, N4, N5 [a11], and N6) are duplicates of the above namesake alternatives but without caustic leaching and additional water washing. In the "N" alternatives, the volume of liquid transferred to the evaporator for processing is reduced because leaching and special washing are not included. In alternative $7 \mathrm{~b}$ alternative $7 \mathrm{a}$ was modified and optimized to concentrate AZ-102 waste by in-tank evaporation instead of in the 242-A evaporator.

For all alternatives except Alternative 0 a, experimental verification that $A Z-101$ and $A Z-102$ high-heat aging waste supernate can be concentrated without significant precipitation is required. The best alternative may be to take samples of the supernate and concentrate them in the laboratory.

\subsection{EVALUATION OF REMAINING ALTERMATIVES VERSUS SELECTION CRITERIA}

\subsubsection{Alternative's Satisfaction of Raw Decision Criteria}

In al1 cases, the data used to evaluate the performance of NCAW consolidation alternatives are based on best engineering judgment. Detailed analysis was carried out to generate the data. The performance of alternatives to the decision criteria is shown in Table $3-3$. This section provides an understanding of the bas is for the data.

The assumptions and reasoning behind gathering the data are given in Appendix $C$. The discussion topics are arranged in the same order as in the waste decision criteria outline, Section 3.2.2.3. 
Table 3-3. Results of Raw Decision Criteria Evaluation. (sheet 1 of 2)

\begin{tabular}{|c|c|c|c|c|c|c|c|c|c|c|c|c|c|c|c|}
\hline \multicolumn{2}{|r|}{ Alternatives } & \multicolumn{14}{|c|}{ Performance measurea } \\
\hline $\mathbf{0 a}$ & Do Nothing & 15 & 14000 & 75 & 2 & 6 & 0 & 0 & 1 & 1 & 17 & 0 & 9 & 1 & 0 \\
\hline$\overline{1 a}$ & Pipe Rerout A2101 & 20 & 22000 & 80 & 3 & 12 & 1 & 1 & 1 & 1 & 16 & 0 & 12 & 1 & 0 \\
\hline$\frac{16}{16}$ & REC to $A$ Z101 & 18 & 17000 & 55 & 3 & 9 & 1 & 2 & 2 & 2 & 16 & 1 & 12 & 2 & 0 \\
\hline 2 & 242-A Evaporator & 20 & 15000 & 75 & 3 & 10 & 1 & 0 & 1 & 1 . & 15 & 1 & 14 & 1 & 0 \\
\hline 3 & Bum Dent to AZ101 & 16 & 15000 & 100 & 3 & 11 & 1 & 1 & 1 & 2 & 16 & 0 & 10 & 1 & 1 \\
\hline 4 & ReC to $\mathrm{MZ102}$ & 18 & 17000 & 55 & 3 & 9 & 1 & 1 & 2 & 2 & 16 & 1 & 12 & 2 & 0 \\
\hline 5 & Planning Case & 22 & 24000 & $\overline{78}$ & 3 & 9 & 1 & 2 & 4 & 4 & $\overline{15}$ & 0 & 14 & 4 & 1 \\
\hline $5 \mathbf{b}$ & P.C. + AY102 & 27 & 25000 & 50 & 3 & 9 & $\mathbf{1}$ & 2 & 3 & 3 & 16 & 1 & 19 & 5 & 1 \\
\hline 5 & P.C. + AY101 & 27 & 25000 & 55 & 3 & 9 & 1 & 3 & 5 & 3 & 17 & 1 & 19 & 5 & 1 \\
\hline 6 & Uhimate Retrieval & 30 & 25000 & 30 & 3 & 9 & 1 & 3 & 6 & 6 & 17 & 1 & 22 & $\overline{6}$ & 1 \\
\hline$\overline{7 a}$ & 75-HP Mixer & 17 & 16000 & 65 & 3 & 12 & 1 & 0 & 2 & 2 & 16 & 1 & 11 & 2 & 0 \\
\hline $\mathbf{7 b}$ & 75-HP Mixer & 15 & 16000 & 65 & 2 & 12 & 0 & 0 & 2 & 2 & 27 & 1 & 11 & 2 & 0 \\
\hline $\mathbf{N 1 \Omega}$ & & 20 & 21000 & 63 & 3 & 12 & 1 & 0 & 1 & 1 & 16 & 1 & 11 & 1 & 0 \\
\hline N1b & & 18 & 15000 & 37 & 3 & 9 & 1 & 0 & 2 & 2 & 16 & 1 & 12 & 2 & 0 \\
\hline$\sqrt{3}$ & & 16 & 15000 & 95 & 3 & 11 & 1 & 0 & 1 & 2 & 16 & 0 & 10 & 1 & 1 \\
\hline N4 & & 13 & 15000 & 37 & 3 & 9 & 1 & 0 & 2 & 2 & 16 & 1 & 12 & 2 & 0 \\
\hline N5a & & 22 & 22000 & 65 & 3 & 9 & 1 & 0 & 4 & 4 & 15 & 1 & 14 & 4 & 1 \\
\hline N5b & & 27 & 23000 & 25 & 3 & 9 & 1 & 0 & 5 & 5 & 16 & 1 & 19 & 5 & 1 \\
\hline N5c & & 27 & 23000 & 38 & 3 & 9 & 1 & 0 & 5 & 5 & 17 & 1 & 19 & 5 & 1 \\
\hline N6 & & 30 & 23000 & 0 & 3 & 9 & 1 & 0 & 6 & 6 & 17 & 1 & 22 & 6 & 1 \\
\hline
\end{tabular}


Table 3-3. Results of Raw Decision Criteria Evaluation. (sheet 2 of 2)

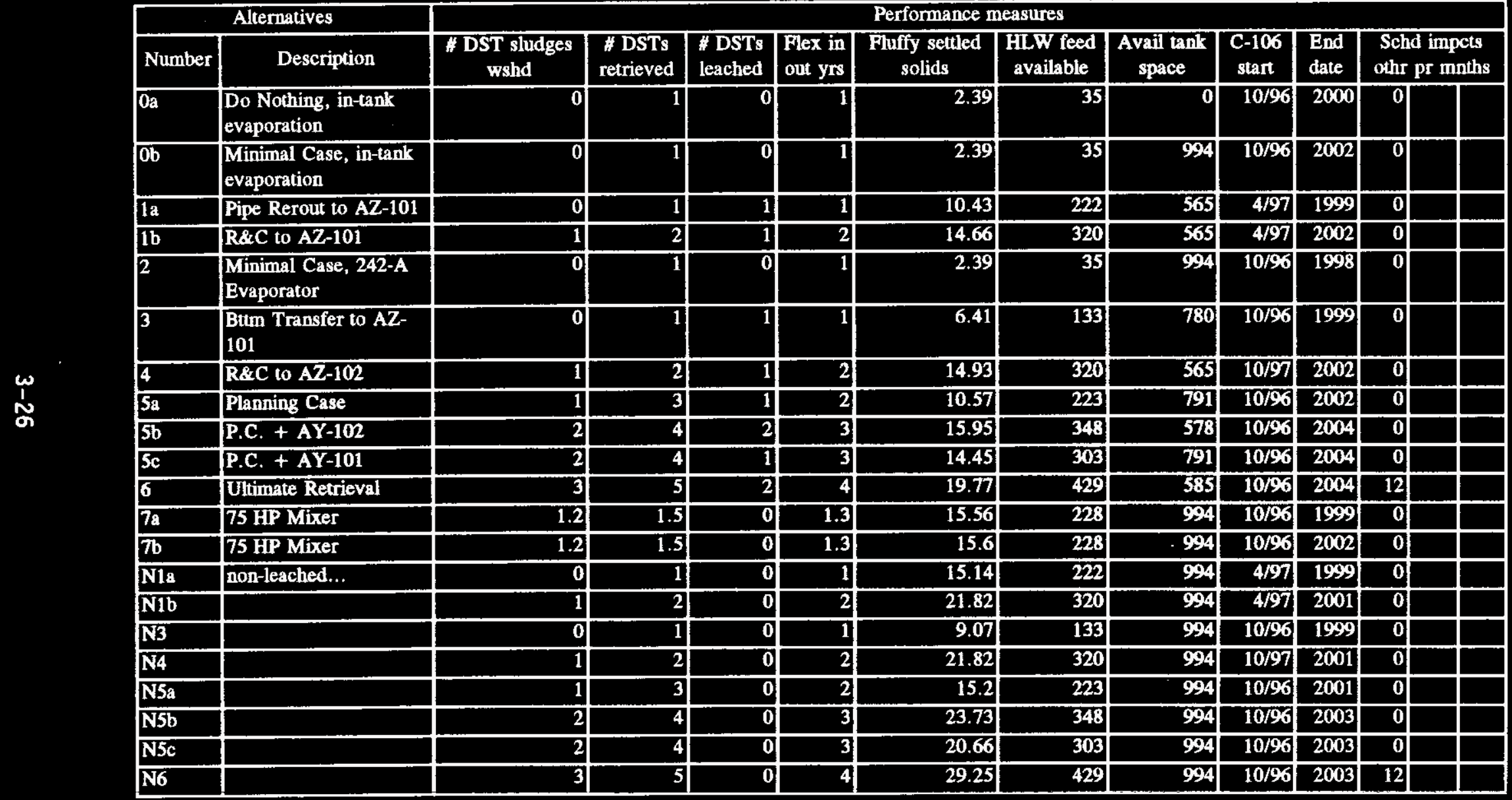




\subsubsection{Weighing of Selection Criteria}

Value functions capture the importance of different levels of performance on a single objective, weights capture the relative importance of the different objectives or values. For example, weights answer the question of whether the technical risks are more important than the operational risks. Weights logically depend on the potential ranges over which the alternatives can vary. A common error is to specify weights in a "top down" process without considering the potential ranges of the impacts. The method used to develop the weights in this study tied the importance of objectives to their ranges in a "bottom up" assessment process.

The methodology used for determining the relative weights is a standard decision analysis procedure known as "swing weighting." This procedure requires that the set of criteria within each category or subcategory first be ordered according to rank, and then the ratios of relative importance are determined. Evaluators are asked to consider a situation in which a hypothetical alternative would score at the worst level for all criteria within a particular category. They are then asked to imagine that if the alternative could be improved to the best level on one criterion, which criterion would be their first choice for the improvement, second choice, etc. This provides a bas is for the rankings. Ratio judgments of relative importance are then obtained. The process is repeated for each of the categories and extended to obtain judgements across categories. The importance ratios are normalized so the sum of weights across all categories is one.

Weights were elicited from the evaluation team. Weights represent value judgments; consequent1y, there is no "correct" answer as to the relative importance that should be given to various criteria. This is in contrast to estimates of performance which, while they may not be known, are thought to have correct answers. The process used for eliciting weights consisted of individuals making independent judgments followed by a group discussion. In most instances for this team, a consensus was reached. In two instances, team participants believed strongly enough about their differences that two "outlier" sets of weights also were considered.

No attempt was made in the weight elicitation to trade off the performance criteria against dollar costs. The analysis uses the elicited weights to arrive at an overall "benefit" score for each technical alternative and then directly compare performance on overall value with cost. This method of analysis makes it possible to identify dominating alternatives, i.e., technical alternatives that provide more value for less cost. It also keeps visible the cost-performance trade-offs among the dominating alternatives. Thus, the reader can decide whether the higher performing alternatives are worth the additional cost.

The weights resulting from the elicitation are shown in Table 3-4. The first column in the table shows the major categories of values, in bold, along with the subcriteria. The next column is an abbreviated description of the scale associated with the subcriteria. The next three columns show group weights, used in the main analysis, and the two outlier weights. Each column shows the weights for the major public values (shaded) as well as weights for the specific subcriteria. The sum of the shaded numbers and the non-shaded numbers is one. Thus, the shaded numbers capture the relative importance of 


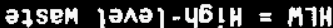

xuez 11 pus-ajqnod $=150$

sIJaroyd to sIJYdHI OJHJS व7swo IISVA to 31V0 OH $901-3$ to $31 \mathrm{YO}$ I8VIS

\begin{tabular}{|c|c|c|c|c|}
\hline 500.0 & 200.0 & 500.0 & KEјЕр s47uot :050 $\mathrm{M}$ & SLJEROyd to SIJYdHI GIHJS \\
\hline$S S 0^{\circ} \mathrm{O}$ & 220.0 & 7500 & әJ8P PUS & 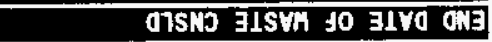 \\
\hline 1100 & $710^{\circ} 0$ & $110^{\circ} 0$ & गJ8p 7JE7S & $901-3$ to $31 \% 0$ IYVIS \\
\hline 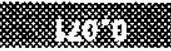 & 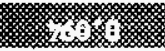 & 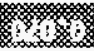 & & 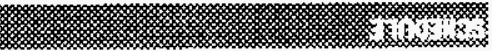 \\
\hline 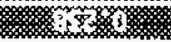 & 装 & $x$ & wh & 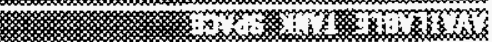 \\
\hline$S \angle 0^{\circ} 0$ & $0.1 \% 0$ & $520^{\circ} 0$ & $106 x$ & 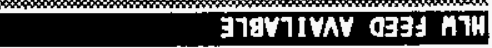 \\
\hline 1600 & 9100 & 11000 & $200 / \%$ & 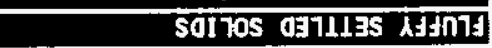 \\
\hline ESOO 0 & 2200 & 1500 & 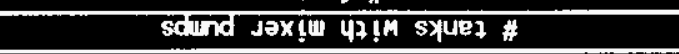 & SExoyd S:A-InO WI XaTH \\
\hline 510.0 & $120 \%$ & $\$ 10^{\circ} 0$ & p9ypeal s1sa \# & \\
\hline $670^{\circ} 0$ & $1 \angle 0^{\circ} 0$ & $\angle 700^{\circ} 0$ & pana!j子aj sLsa \# & \\
\hline \multirow[t]{2}{*}{$210^{\circ} 0$} & $810^{\circ} 0$ & $210^{\circ} 0$ & paysem sabpnjs 1sa \# & \\
\hline & & & & motLYRosinI ssajoyd \\
\hline 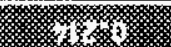 & 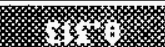 & 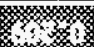 & & , n w \\
\hline $070^{\circ} 0$ & $010 \% 0$ & $650^{\circ} 0$ & s7uessp lioj709 fo \# & 8JdO ITYJO WOL100 \\
\hline $620^{\circ} 0$ & $120^{\circ} 0$ & $820^{\circ} 0$ & paz!1!qot: sebph|s Iso \# & 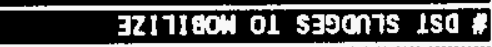 \\
\hline 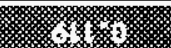 & 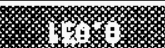 & 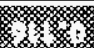 & & 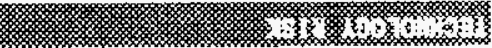 \\
\hline 8200 & $920 \%$ & 2200 & 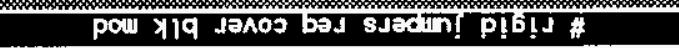 & 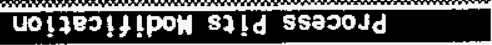 \\
\hline \multirow[t]{2}{*}{9000} & $200 \%$ & $500^{\circ} 0$ & 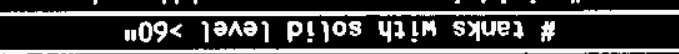 & 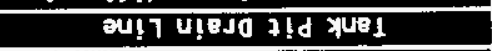 \\
\hline & & & & SCOW INBHdInos XWY1 \\
\hline $220^{\circ} 0$ & $180^{\circ} 0$ & $\mathbf{2 Z O} 0$ & S Jafsuedt afeujachs y juesap \# & \\
\hline $270 \div 0$ & $190^{\circ} 0$ & 970 & sjaj suejt p! jos \# & sjajsued to \# \\
\hline $710^{\circ} 0$ & $810 \cdot 0$ & $510^{\circ} 0$ & saspnjs jo bu!x!W \# & \\
\hline $220 \cdot 0$ & $620 \% 0$ & $120^{\circ} 0$ & sayjeal pue saysen \# & \\
\hline \multirow[t]{2}{*}{22010} & $920^{\circ} 0$ & 2200 & ә7sen fea4-45!y s605 of sunj dena to \# & Lo!jededo 7 !un \# \\
\hline & & & & 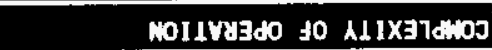 \\
\hline 倅 & 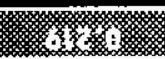 & 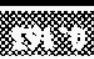 & & 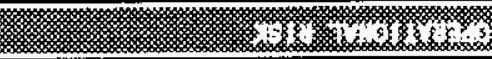 \\
\hline 900.0 & $900^{\circ} 0$ & $800 \cdot 0$ & 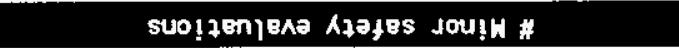 & \\
\hline 2200 & 2200 & $0 \% 0$ & 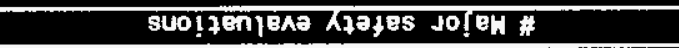 & X7! !! \\
\hline \multirow[t]{2}{*}{$0 \div 0.0$} & $070^{\circ} 0$ & $6 \% 0$ & 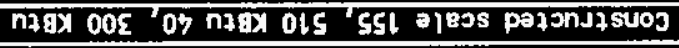 & scing Yus1 \\
\hline & & & & 113dYS XKY \\
\hline $870^{\circ} 0$ & $\angle 700^{\circ} 0$ & $850 \%$ & Sasusyo Jactin \# \# & 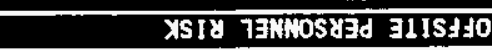 \\
\hline $890^{\circ} 0$ & 5900 & $820^{\circ} 0$ & प19J14 & त्रSTY TBMnOS:Id \\
\hline 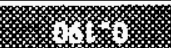 & 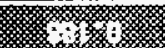 & 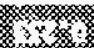 & & 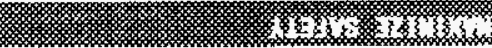 \\
\hline 1 Ja! 1 Tho & g do! 1 Tho & TOJ & & \\
\hline \multicolumn{3}{|c|}{ JojEn|8A3 } & sajnseall asuetnjofjad & e!Ja J! J \\
\hline
\end{tabular}

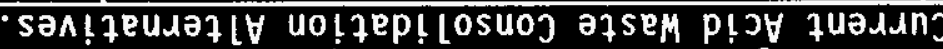

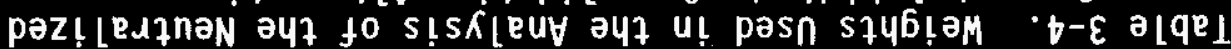


WHC-SD-WM-ER-532

Revision 0

the major criteria, and the non-shaded numbers provide the relative importance of specific criteria across all categories. Note that Available Tank Space is a major category and also a specific criteria. Thus, its weight needs to be added to the non-shaded weights so the sum is one.

As can be seen in Table 3-4, both outlier $G$ and outlier 1 judged the safety risks to be of less concern than the group as a whole. Outlier $G$ placed more weight on operational risk and on the feed preparation process and more weight on schedule. Outlier 1 placed more weight on making tank space available. The alternatives were initially analyzed with all three sets of weights. Alternative rankings with the three sets of weights were not very different; consequently, the majority of the analysis was carried out using the "group" weights. These analyses are discussed further in the following sections.

\subsubsection{Ranking of Alternatives/Analysis}

The data shown in Table 3-3 represent the facts used in the analys is of the NCAN consolidation alternatives. No alternative scored best on all criteria; consequently, additional analysis that considers costs and benefits and the judgments of trade-offs among values is needed. The following subsections analyze the strengths and weaknesses of the NCAN consolidation a)ternatives.

Figure 3-4 shows the results of the analys is of NCAN consolidation alternatives' overall performance on the criteria. Performance on values is considered from each of three value perspectives. An analys is of the costbenefit trade-offs, which reveal about six alternatives that are the leading contenders, is presented. Most of the other alternatives provide less value at more cost. A detailed analysis showing which specific criteria are driving the overall performance of the alternatives, and identifying the trade-offs, is presented.

3.6.3.1 Overal1 Performance on Decision Criteria. Figure 3-4 shows the alternative's overall numerical value and a bar graph illustrating the score. Alternative $7 \mathrm{~b}$ scored higher than all others by about $2.7 \%$ of the highest score. Alternatives $\mathrm{Ob}, \mathrm{Nlb}, \mathrm{N4}$, and $7 \mathrm{a}$ scored closely in a group, and Alternatives N1a, N3, and 2 and were the third group.

The overall consolidation benefit scores were determined by taking the raw scores on each of the criteria and transforming them into a value from 0 to 1 using the value functions for the criteria, and then taking a weighted sum of these values where the weights used were the group weights as described in this report. The resulting scores have a potential range from 0 to 1 , where 1 would indicate the highest possible score on all criteria and 0 would result from the lowest score on all criteria. As can be seen in Figure 3-4, the scores ranged from 0.31 to 0.73 . 
WHC-SD-WM-ER-532

Revision 0

Figure 3-4. Overall Performance on Decision Criteria.

\section{Alternative Value}

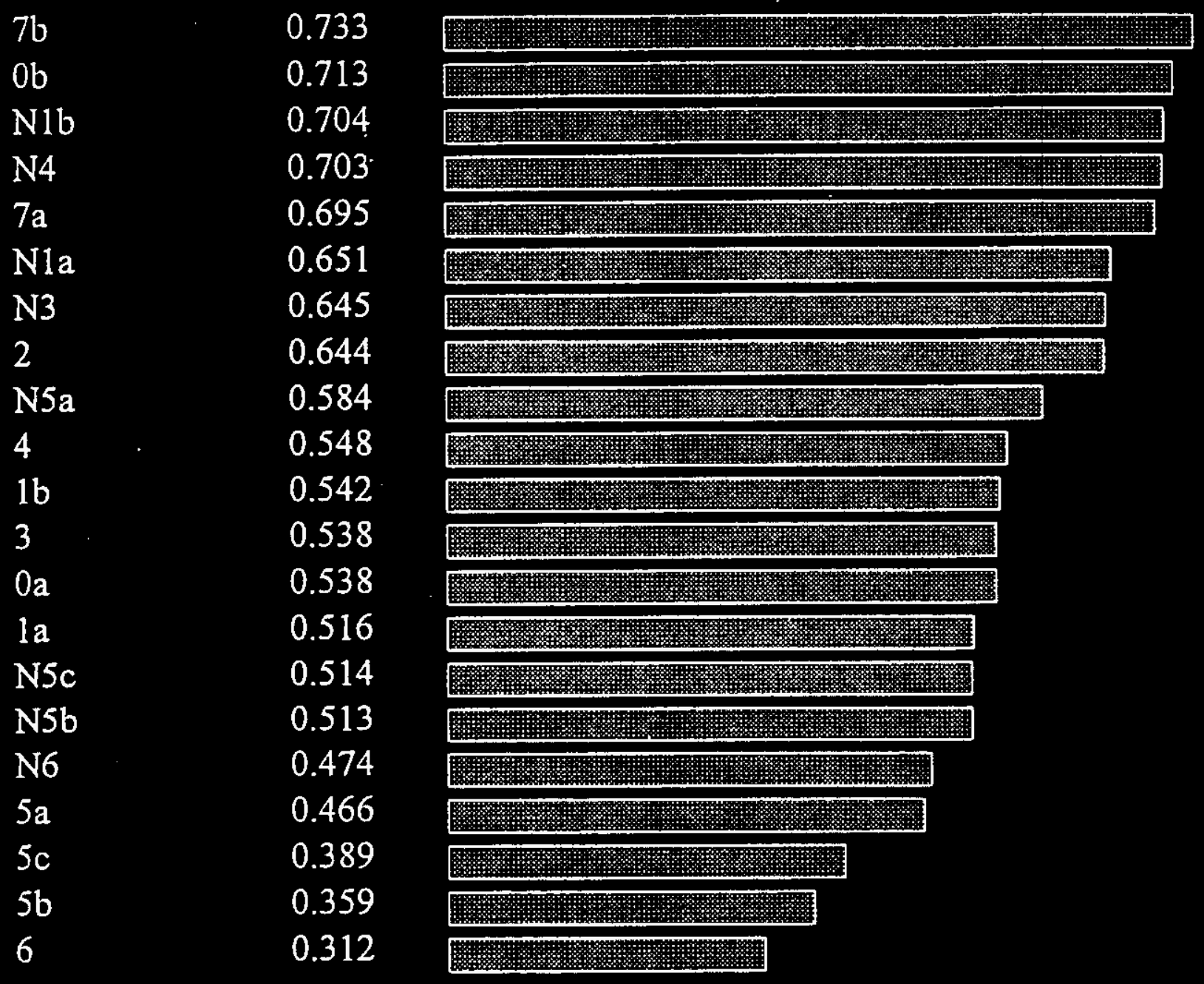

Preference Set $=$ Group.Set 
WHC-SD-WM-ER-532

Revision 0

In every case, it was found that the sister alternatives that did not contain special caustic leaching and washing unit operations recoded a better value than those that did (value of N1a>1a, N1b>1b, N3>3...).

These overall values do not consider cost. They are a weighted sum of al1 criteria with the exception of cost. Cost-benefit trade-offs will be considered in the following subsections.

3.6.3.2 Overall Performance from Different Value Perspectives. The overall values shown in Figure 3-4 depend, in part, on the weights used to trade off the values. Three sets of weights were developed as described in this report: one majority consensus and two outliers. A comparison of the results using these three different value perspectives is shown in Figure 3-5. As can be seen in the figure, an analys is from all three value perspectives results in Alternative $7 b$ or ( $0 b$ followed by $7 b$ in outlier 1 ) having the highest score and Alternative 6 having the lowest score. Also, Alternatives $7 \mathrm{~b}, 0 \mathrm{~b}, \mathrm{~N} 1 \mathrm{~b}$, $7 \mathrm{a}$, and $\mathrm{N} 4$ are the top five scores from all three perspectives. In general, the overall pattern of rankings, as seen in Figure 3-5, is similar.

Consequently, subsequent analys is is carried out using the group weights.

3.6.3.3 Cost-Benefit. Analysis. The costs of the NCAW consolidation alternatives are given numerically and shown graphically in Figure 3-6. Costs were estimated for capital and expense. Costs range from $\$ 23$ million to $\$ 132$ million. As can be seen in Figure 3-6, Alternative 6 has the greatest total cost and Alternative 0 a the least. For many of the alternatives, capital cost is small. Year-to-year expense cost profiles are given for each alternative in Appendix A. A detailed analysis of the expense and cost elements for each alternative is given in Appendix $A$.

To more clearly depict the relationship between costs and benefits, the alternatives are plotted in a two-dimensional cost-versus-benefit space shown in Figure 3-7: the horizonal axis is the total cost and the vertical axis is the overall value. The best alternatives are in the upper left corner of the figure; these alternatives provide the most value for the least cost. The alternatives in the upper left corner dominate those that are below and to the right, which provide less value at more cost.

Figure 3-7 shows a somewhat negative correlation between cost and value. The higher-valued alternatives tend to cost less. This is a somewhat unusual situation in that there is usually positive correlation between cost and value. The reason for the negative correlation may be that the more costiy alternatives are more involved in terms of the number of transfers, etc., and thus incur more risks than the simpler, less costly alternatives. Safety and risk were heavily weighted in the analysis.

Alternative $7 b$ clearly has the most value and is close to having the least cost. A consideration of overall value and cost suggests the following alternatives as the leading contenders: $7 \mathrm{~b}, 0 \mathrm{~b}, 7 \mathrm{a}, 2$, and $\mathrm{N3}$. Alternative $7 \mathrm{~b}$ provides more value than Alternative $\mathrm{N} 3$ for a slight increase in cost. This is because Alternative N3 uses the 242-A evaporator to concentrate the aging waste supernate in $\mathrm{AZ}-102$. 
WHC-SD-WM-ER-532

Revision 0

Figure 3-5. Comparison of Team Values with Outlier Values.

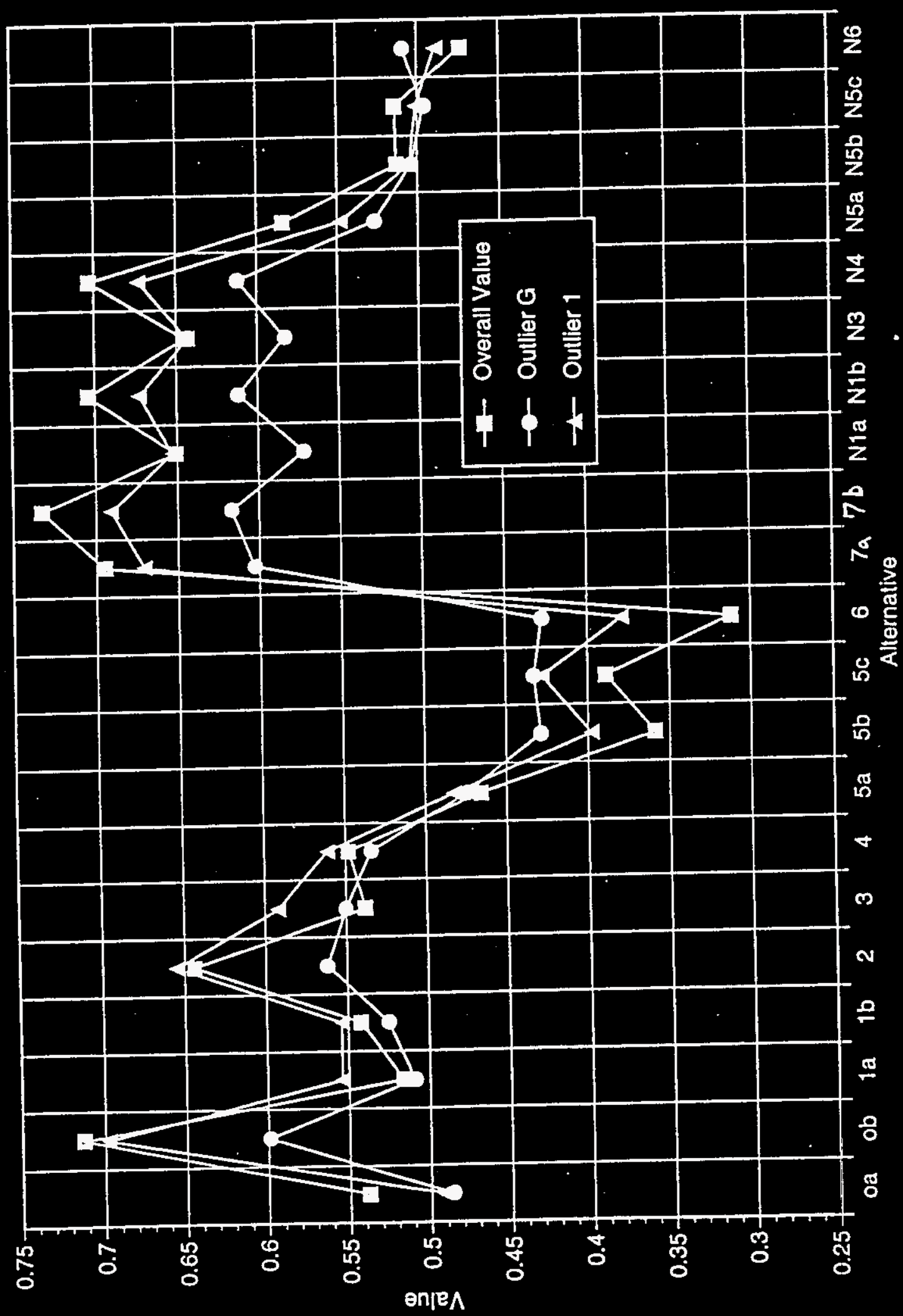




\section{WHC-SD-WM-ER-532 \\ Revision 0}

Figure 3-6. Costs for Neutralized Current Acid Waste Consolidation Alternatives.

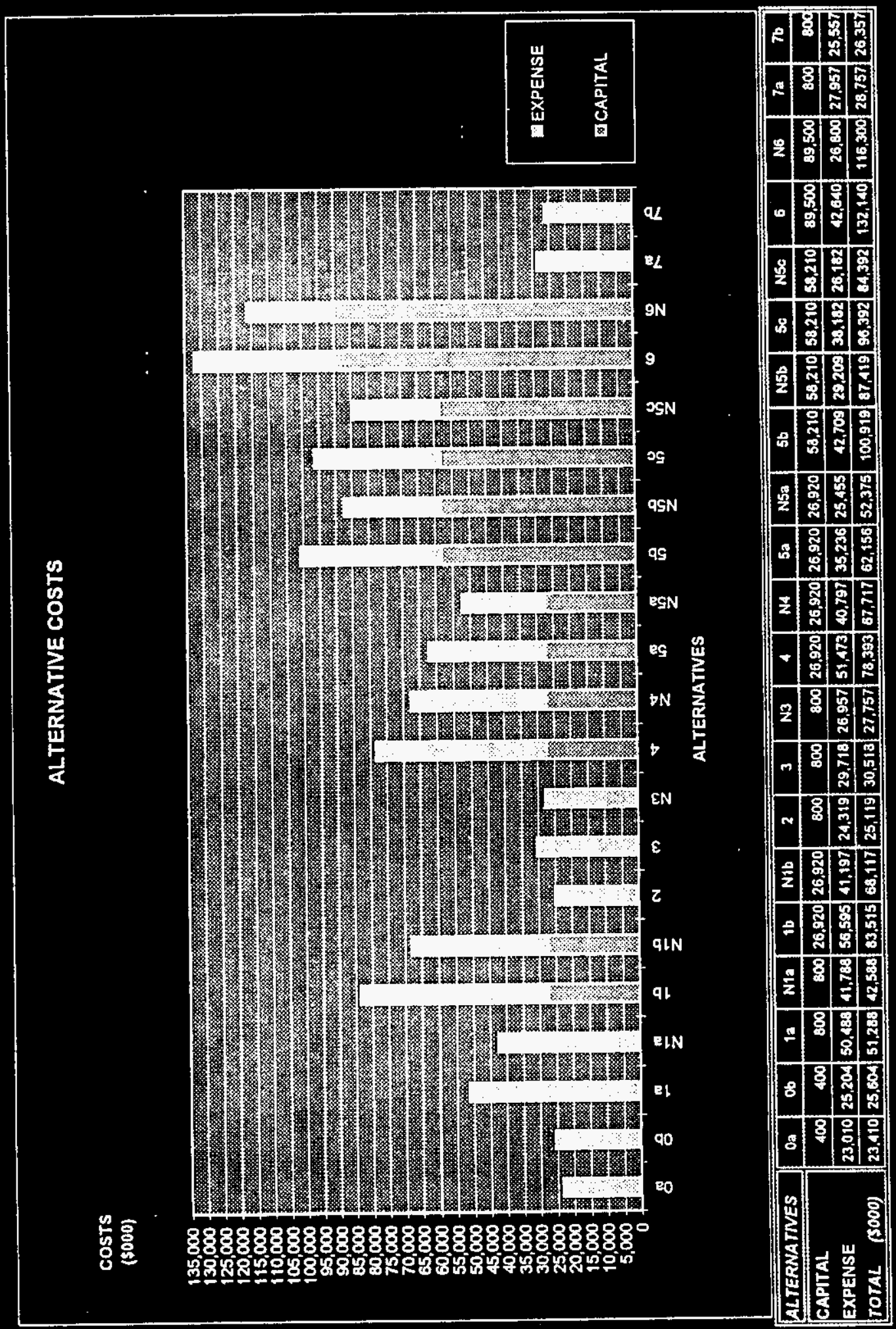


WHC-SD-WM-ER-532

Figure 3-7. Overall Value Versus Total Costs.

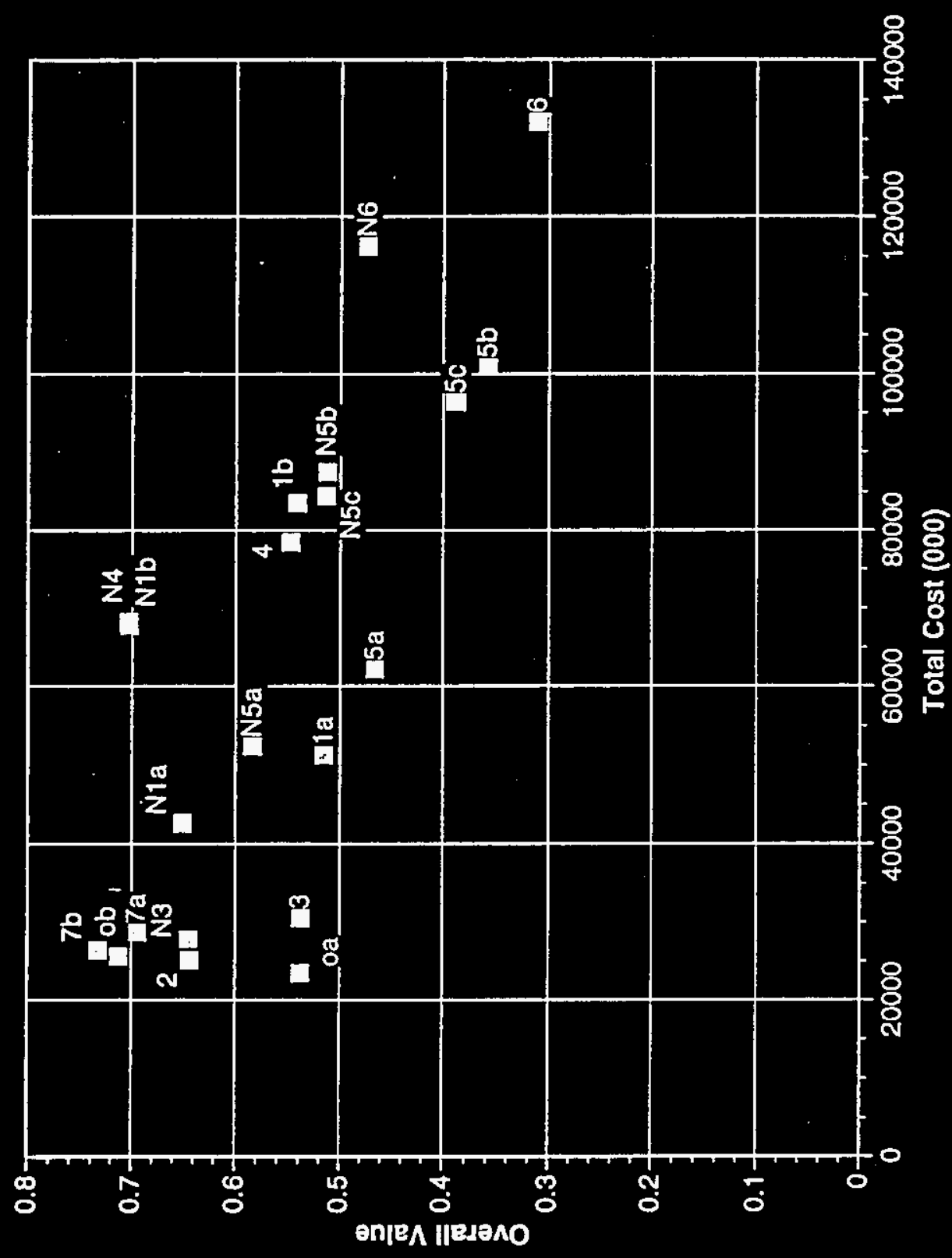


WHC-SD-WM-ER-532

Revision 0

If Alternative N3 were to be rerun using in-tank evaporation, it would score about 0.68 and cost less than Alternative $7 b$ due to the reduced cost of running the 242-A evaporator. More detailed comparisons and analyses are presented in following subsections.

3.6.3.4 Performance and Safety/Risk Comparisons. Some of the primary purposes of the NCAW consolidation effort are to make available both tank space and HLW feed. To accomplish this, there are two categories of costs: (1) the dollar cost that must be paid, and (2) the cost in terms of personne? safety and technical and operating risks. The calculation of overall value is based on $>50 \%$ of the weight being placed on safety and risk. It is instructive to look more closely at the trade-offs between performance and safety/ risk.

3.6.3.4.1 Safety and Risk Versus Available Tank Space. For a better understanding of the relationship between safety/risk and tank space availability, alternatives are plotted in a two-dimensional space of safety/ risk versus tank space as shown in Figure 3-8. The best alternatives are in the upper right corner of the figure; these alternatives maximize safety and minimize risk while making the most tank space available. Alternative ob is the dominant alternative from this perspective. Other alternatives to be considered, in order, are 7b, 2, N3, 7a, N1a, N1b, and N4. The other alternatives score poorly on either the amount of tank space made available or on safety and risk.

3.6.3.4.2 Safety and Risk Versus Available HLW Feed. Safety and risk versus HLW feed made available were considered next. A comparison of a)ternatives on these two dimensions are shown in Figure 3-9. The best alternatives from this perspective are in the upper right corner of the figure. Alternatives $\mathrm{NIb}, \mathrm{N} 4,4$, and $1 \mathrm{~b}$ provide more $\mathrm{HLW}$ feed than the Planning Case (Alternative $5 \mathrm{a}$ ) and score moderately well on safety/risk. Alternatives $7 \mathrm{~b}, 7 \mathrm{a}, \mathrm{Nla}$, and la scored equal to the Planning Case (Alternative 5a) on HLW feed, and Alternative $7 \mathrm{~b}$ scored significantly better in safety and risk than did others near the upper right corner of the chart. Alternatives $0 \mathrm{a}$ and $\mathrm{Ob}$ scored high on safety and risk; however, they make only a minimum amount of HLW feed available. Alternative ob is especially conspicuous as it was the first or second leading contender from the perspective of overall value, cost, and tank space. However, it makes only the minimum amount of tank feed available.

\subsubsection{Summary of Initial Analysis}

A discussion of the initial analysis is summarized in Table 3-5, which shows the leading alternatives from the perspective of overall value without consideration of cost, cost versus overall value, safety/risk versus tank space, and safety/risk versus HLW feed available. Alternatives with the most value are shown first, the ones with the least value (among the top six to eight alternatives) are shown last. Natural break points were taken to determine the number of alternatives chosen from each chart/table. 
WHC-SD-WM-ER-532

Revision 0

Figure 3-8. Tank Space Avallable Versus Safety/Risk.

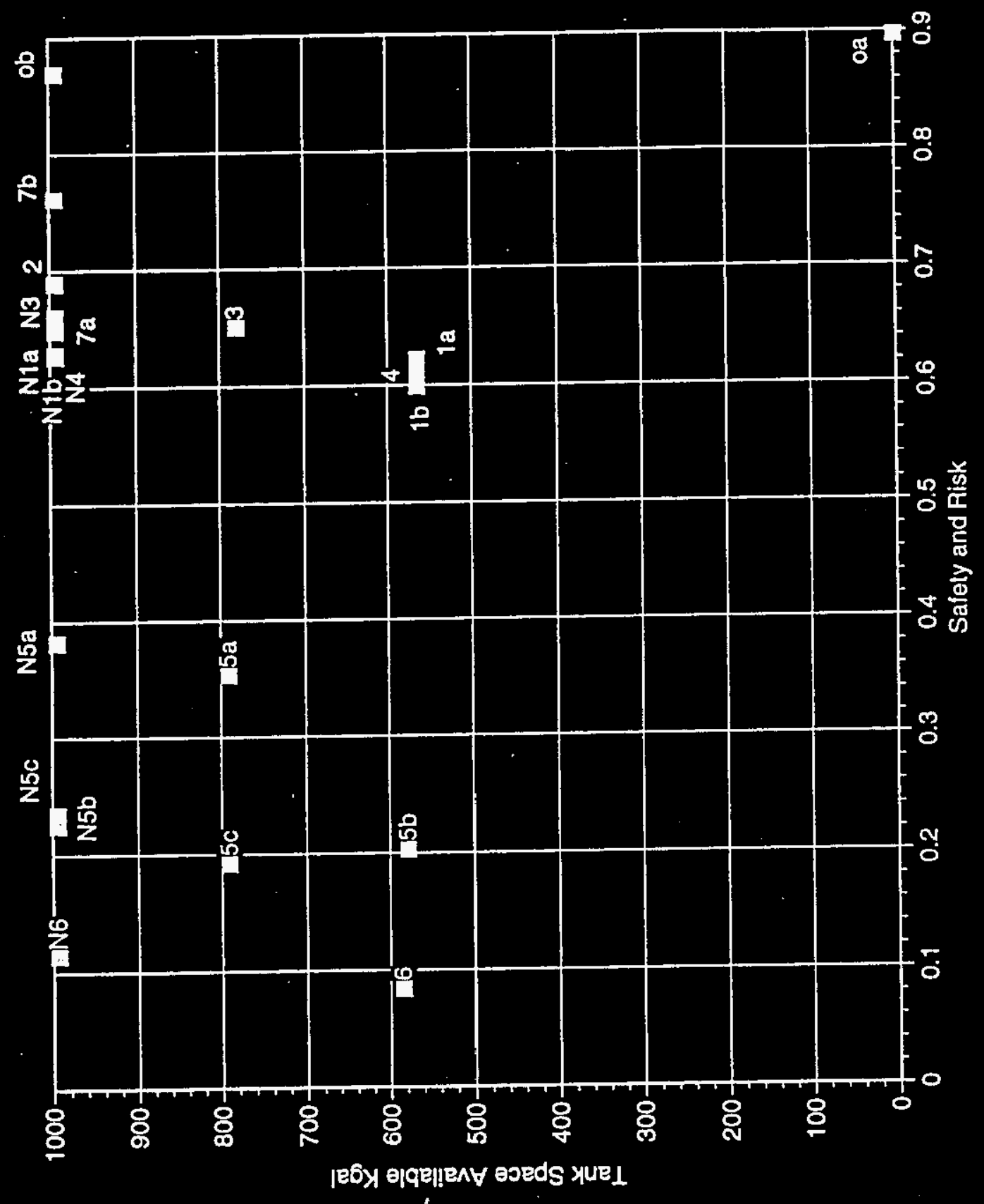


WHC-SD-WM-ER-532

Revision 0

Figure 3-9. High-Level Waste Feed Available Versus Safety/Risk.

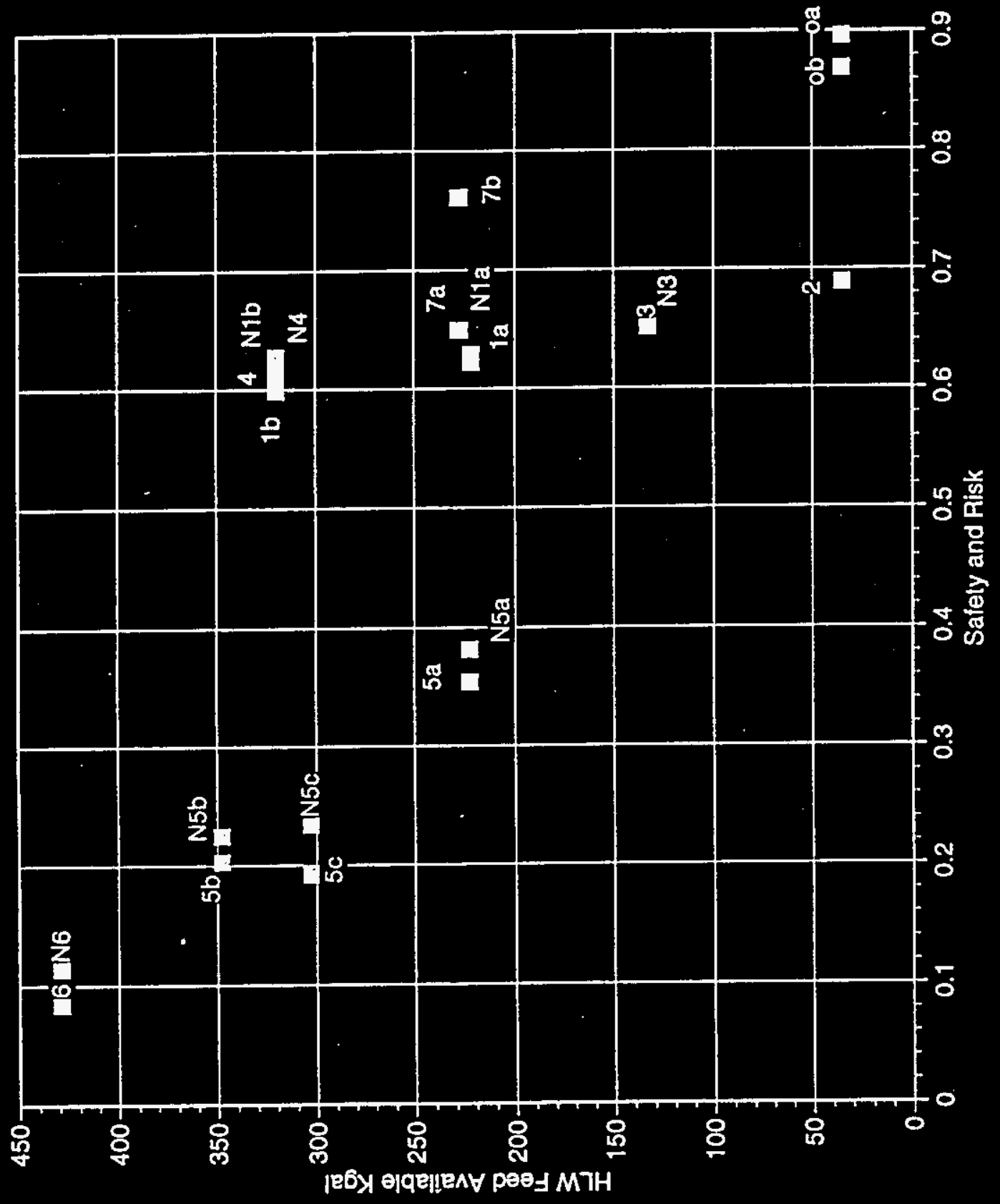


The boxes in Table 3-5 that show multiple entries are ones that have virtually no difference between alternatives. Alternatives that are common winners from all five of these considerations are $7 b$ and $7 a$.

\subsubsection{Sensitivity Analysis}

A sensitivity analysis was conducted to explore the strength of alternative rankings to changes in the weight assigned to major value

Table 3-5. Consolidation Results.

\begin{tabular}{|c|c|c|c|c|}
\hline Ranking & $\begin{array}{c}\text { Overal1 } \\
\text { value } \\
\text { only }\end{array}$ & $\begin{array}{c}\text { Cost vs. } \\
\text { value }\end{array}$ & $\begin{array}{c}\text { Safety and } \\
\text { risk } \\
\text { vs. HLW feed }\end{array}$ & $\begin{array}{c}\text { Tank space } \\
\text { vs. safety } \\
\text { and risk }\end{array}$ \\
\hline 1 & 7b & 7b & Ob & $7 b$ \\
\hline 2 & Ob & Ob & $7 b$ & $\begin{array}{c}\text { N1b, N4, } \\
4,1 b\end{array}$ \\
\hline 3 & N1b, N4, & $7 a$ & 2 & $7 a$ \\
\hline 4 & $7 a$ & N2, N3 & N3, 7a & N1a, 1a \\
\hline 5 & N1a, N3, & N1a & N1a, N1b, N4 & -- \\
\hline
\end{tabular}

$H L W=$ High-level waste

categories. This is separate from the sensitivity analys is to different value perspectives as shown in Figure 3-4. The sensitivity analys is to weights placed on the major categories of public values is shown in Figures 3-10, 3-11, and 3-12. Each figure shows the effect of varying the weight placed on one value from $0 \%$ to $100 \%$ while keeping the weights on the other values at their relative proportions.

Figure 3-10 is composed of graphs in the general heading of Safety and Risk. The graphs are arranged from most general at the top to more specific at the bottom. They illustrate what happens when the weight on the individual or general headings is changed.

Figure 3-11 is graphs of weight on the Feed Preparation Process. Again, the graphs are arranged from general at the top of the page to more specific at the bottom of the page.

Figure 3-12 shows graphs of weights on Available Tank Space, Optimize Schedule, and HLW Feed Available. The graph of HLW Feed Available is used to illustrate what happens when the weight of the Decision Criteria is changed. The horizontal axis is the weight placed on HLW feed on a 0 -to-100\% scale. The vertical axis is the value on a 0 -to-l scale. The plotted 1 ines show how the value for each of the technical alternatives changes as a function of the weight placed on HLW feed availability. 
Figure 3-10. Sensitivity Study Safety and Risk.

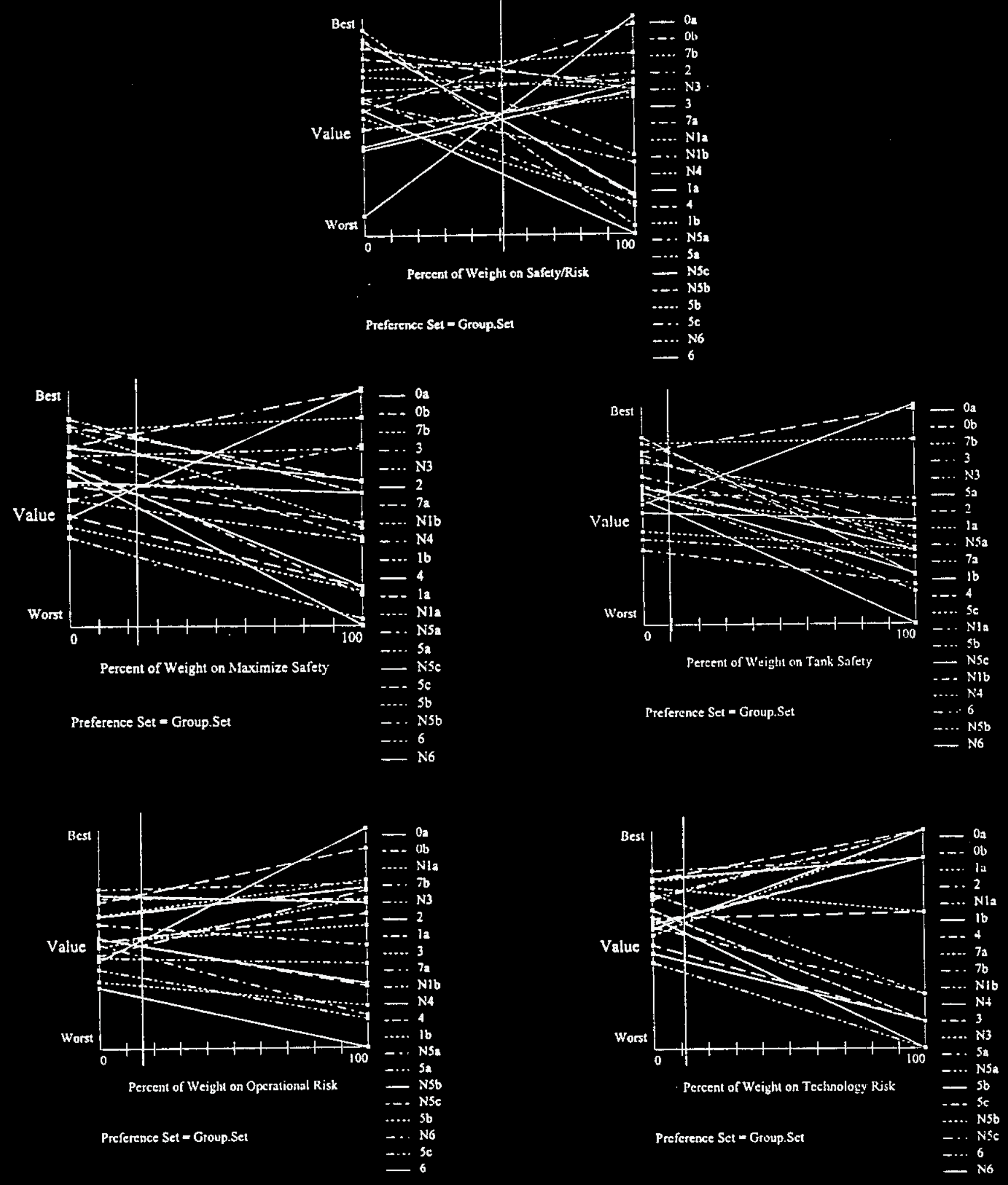


Figure 3-11. Sensitivity Study Feed Preparation Process.

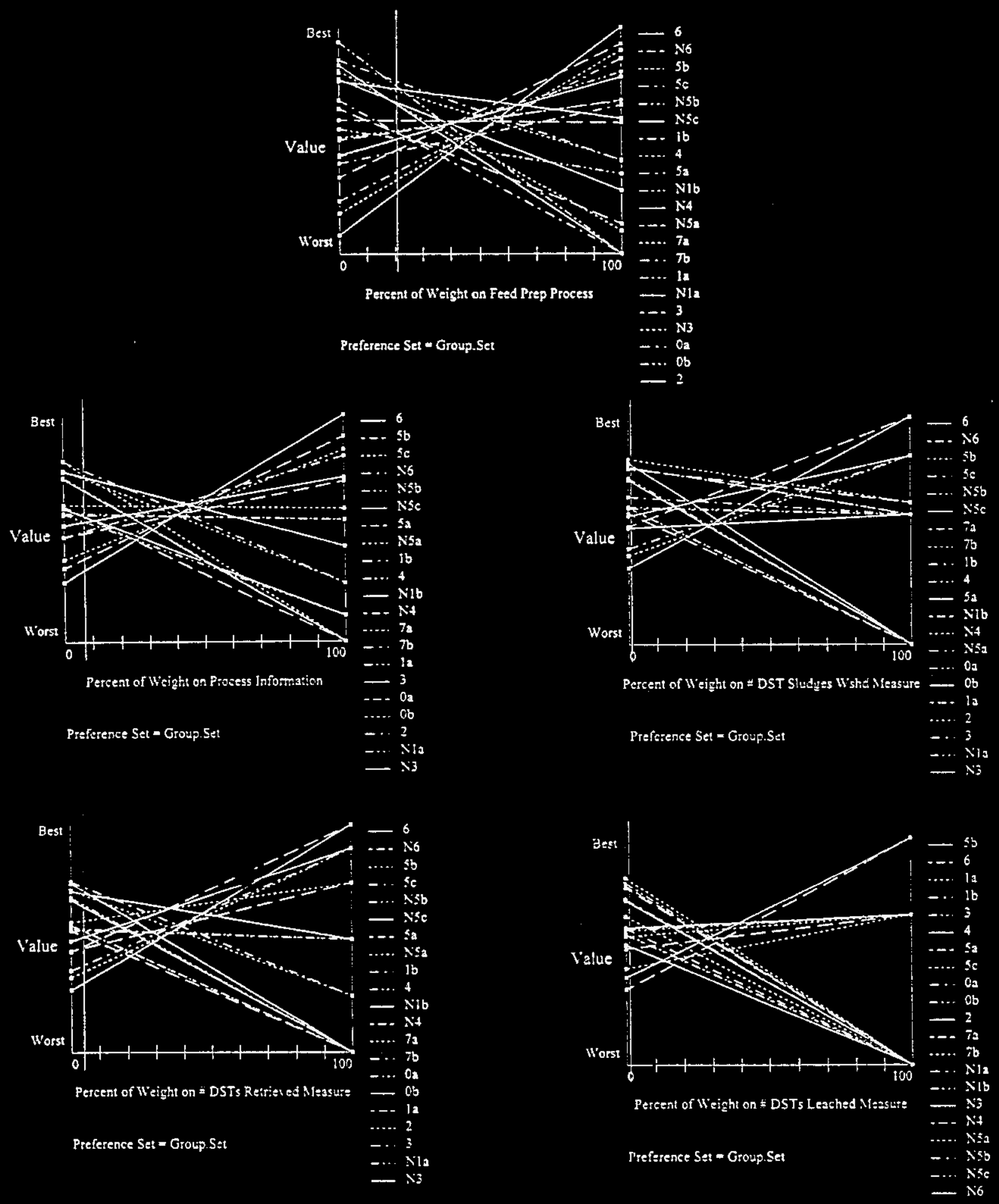


Figure 3-12. Sensitivity Study High-Level Waste Feed, Tank Space, Schedule.
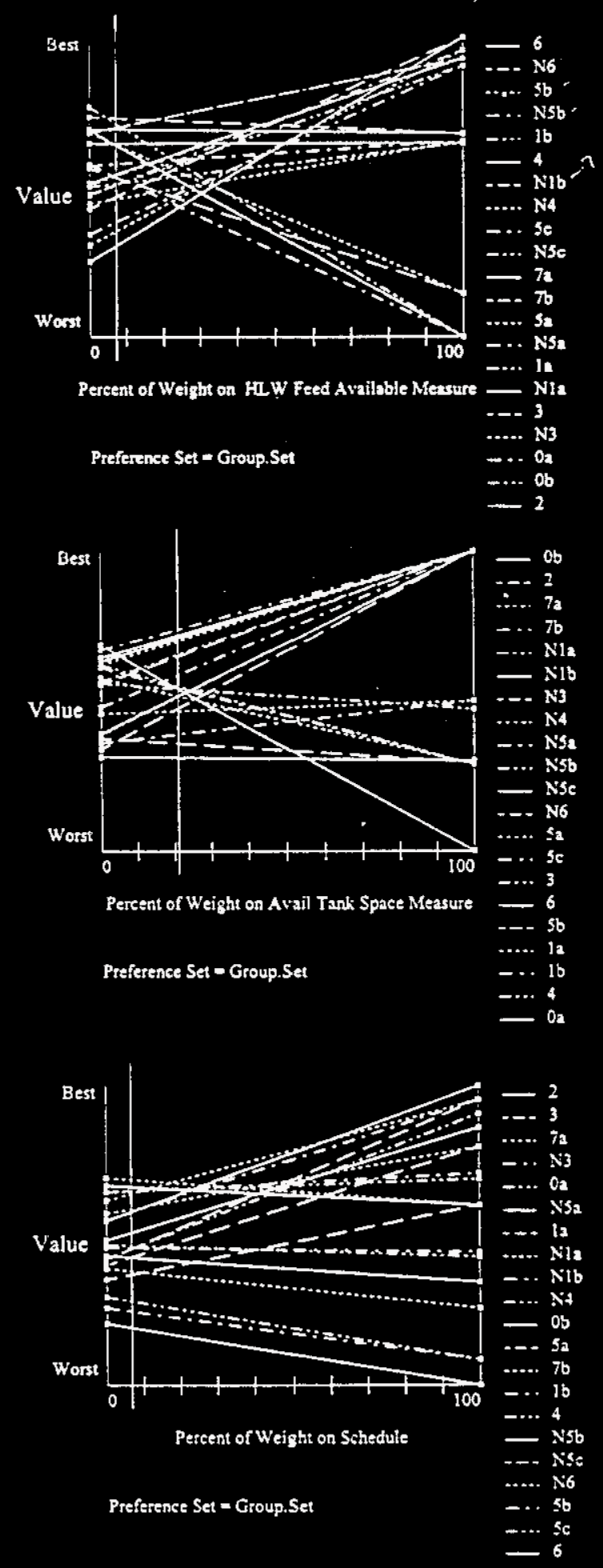
WHC-SD-WM-ER-532

Revision 0

Note that the order in which the lines appear in the legend is the same order in which they fall at $100 \%$ weight on the right.

The other vertical solid 1 ine through $8 \%$ in Figure $3-12$, HLW Feed Available, represents the group's weighting of the HLW feed criteria. The 8\% weighting 1 ine currently indicates that Alternative $7 \mathrm{~b}$, the 75 -hp Mixer Pump in AY-102, without leaching, is the largest value. Mentally changing the weighing by moving the vertical line through $8 \%$ to the left or right will change the outcome of the analysis. It is evident that placing less weight on HLW feed available would change the order of the first alternative when the weighting is reduced to about 6\%; then Alternative $0 \mathrm{~b}$, the Minimal Case alternative, would have the higher value. If additional weight is placed on HLW feed by moving the line to the right, then at about 18\% the leading alternative would change to Alternative N1b, AZ-101 Pipel ine Reroute and Consolidate, without leaching. If the line is cont inued to move to the right, at about $80 \%$ the largest value becomes N6, the Ultimate Consolidation alternative without leaching.

The other graphs in Figures 3-10 and 3-11 are included to allow the reader to determine the effects of modifying the team weighing of the criteria. The other major headings of Safety and Risk, Maximize Feed Preparation Process, Maximize Available Tank Space, and Optimize Schedule are all illustrated. In addition, the subtopics Maximize Safety and Minimize Operational and Technical Risk are shown. In general, modification of the weighing of any of the headings by $50 \%$ or less produces little if any change in the leading six or seven alternatives, which include: 7b, Ob, 7a, N3, N4, $\mathrm{Nlb}, \mathrm{Nla}$, and sometimes 2. Usually, it does not change the top alternative, $7 \mathrm{~b}$, the 75-hp Mixer Pump in AY-102.

\subsubsection{Comparison of Alternative Pairs}

Performance profiles show the relative strengths and weaknesses of each technical alternative. Figure 3-13 indicates some leading alternatives compared to each other and to the Planning Case. These performance profiles show the overall values for the alternatives above the figure. A bar graph is used to quantify the relative amount of value associated with the decision criteria. The decision criteria are found on the left-hand side of the figure. The graph shows the only differences between the two alternatives, not where they rank equally.

The first profile in Figure 3-13 compares the leading alternative (7b), 75-hp Mixer Pump in AY-102, with the Planning Case, Alternative 5a. The 75-hp Mixer Pump in AY-102 alternative leads in every category except in number of DSTs retrieved, and in number of decants and supernate transfers. This indicates that the Planning Case alternative performed worse or equal to the 75-hp Mixer Pump in AY-102 a1ternative in every decision category except those mentioned. Several other figures are shown for other top alternatives. They indicate that the 75-hp Mixer Pump in AY-102. (Alternative 7b) has no major deficiencies compared with other leading alternatives and to the Planning Case al ternative. 
WHC-SD-WM-ER-532

Revision 0

Figure 3-13. Performance Profiles.

$\begin{array}{lll}\text { Overall Value for } & 7 \mathrm{~b}(\text { Ali } 1) & 0.733 \\ & 5 \mathrm{a}(\text { Alt2) } & 0 . \$ 66 \\ & \text { Difference } & 0.267\end{array}$

Planring Cue

Tutal Difictence

Avail Tank Space

* Ajir sfay USQ Eval

Botom Decant Oper

Personnel Risk

Offsite Persa'l Ris

\# runs to enc to ev

\# DST sidgs to mblz

* DSTs Retrieved

\# decant 4 supernat

" solid tratsters

Other

Preference Set $=$ Group.Set

Orezall Value for

$$
\begin{aligned}
& 7 \mathfrak{b}(\text { Alt }) \\
& \mathrm{N} \text { (Alt2) } \\
& \text { Difference }
\end{aligned}
$$

0.733

0.088

Non-Leaching Minimal Cuse

N3 76 75-hp Mtixer Pump in AY:102

Tond Difiorstic

\# Mir sfov USQ Eval

HLW Feed Availabie

Bottom Deesnt Oper

* runs to cne to er

End Date

it decant \& supernat

Tank Bump5

if DST sldes to mblz

\# DSTs Retrieved

f DST Siudges Wishd

Other

Sa 75 -hp Nixer Pump in AY-102

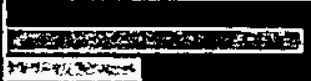

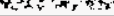

7)

$x+5 \sin =4$

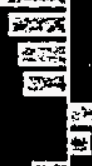

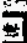

Overall Value for

$7 \mathrm{~b}(\mathrm{Al}: 1)$
NSa $\left(A: i_{2}\right)$
Difference

0.733

\begin{tabular}{|c|c|c|}
\hline Nen-Lesehing Planning Case & $N 5 \mathrm{a}$ & 75. hp Mfixer Pump in AY-102 \\
\hline Tuial Difictante & & 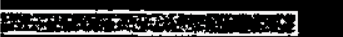 \\
\hline \# Mjr sfty USQ Eval & & 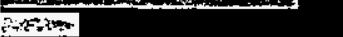 \\
\hline Bottom Decant Oper & & $x \rightarrow$ \\
\hline Personnel Risk & & 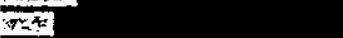 \\
\hline Offsite Persn'l Ris & & 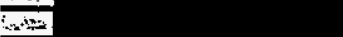 \\
\hline F runs $10 \mathrm{cne}$ to ev & & $9 x$ \\
\hline \# DST sldgs to mbiz & & \\
\hline FSTs Retrieved & 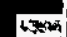 & \\
\hline ff dectint \& stpuntat & 5 & \\
\hline \# solid transfers & & \\
\hline End Date & 接 & \\
\hline Other & & \\
\hline
\end{tabular}

0.584

0.149

Preference Set $\approx$ Group.Set

$\begin{array}{lll}\text { Overall Value for } & \text { 7b (Alt) } & 0.733 \\ & 7_{2}(\text { Alit) } & 0.695 \\ & \text { Difference } & 0.057\end{array}$

75-hp Mixer Pump - 242-A Evaportor $\quad 7 \mathrm{a} \mid 7 \mathrm{~b}$ 75-hp Mixer Pump - In-Tank Coneentration

Tutal Difiterence

\# Mjr sfiy USQ Eval

it tins to cne to ev

End Date

\# decant \& supernat

Offsite Persn'l Ris

Fiutfy sertied soli

-4 a

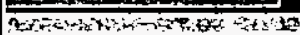

axtrin:

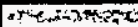

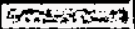

$\pi$

Preference Set - Group.Set

Preference Set $=$ Group.Set 
WHC-SD-WM-ER-532

Revision 0

\subsection{EVALUATION OF ISSUES AND RISK FOR PREFERRED ALTERWATIVE}

The leading alternatives are grouped together and need to be analyzed for potential risk. They include Alternatives $7 \mathrm{~b}, \mathrm{Ob}, 7 \mathrm{a}, 2$, and $N 3$, with Alternatives $\mathrm{N} 4$ and $\mathrm{Nlb}$ trailing behind due to cost.

\subsubsection{Risk Analyses: Alternative Ob, Hinimal Effort, and Alternative 2, Evaporator Concentrate}

Evaluation of the second leading alternative, $0 b$, shows that it provides only a small amount of feed to HLW vitrification, about $16 \%$ of that called for in the Planning Case, Alternative 5a (Bacon 1995). This 1ack of HLW feed would require serious restructuring of the HLW feed pilot plant phase 1 efforts, and would remove only a small volume of HLW feed $(132,000 \mathrm{~L}$ $[35,000$ gal] in AZ-101) from the DST system. This alternative might be made workable from the privatization viewpoint, but it would significantly change existing plans.

The value of Alternative 2, Evaporator Concentrate, is 0.07 less than that of Alternative $0 \mathrm{~b}$. Alternative 2 is the same as Alternative $0 \mathrm{~b}$ except that the AZ-102 supernate is sent to the 242-A evaporator for concentration instead of performing in-tank concentration. It also does not move the recovered $C-106$ sludge from $A Y-102$. This alternative suffers from the same problem as Alternative $0 \mathrm{~b}$ in that it only delivers the sludge already in AZ-101 to HLW disposal.

\subsubsection{Risk Analyses: A1ternatives N1b, Reroute and Consolidate to AZ-101, and N4, Reroute and Consolidate to AZ-102}

These alternatives assume that Project $W-320$, Tank 241-C-106 Waste Retrieval, is complete but that final pumps and equipment have not been installed in $\mathrm{AY}-102$. In A1ternatives $\mathrm{N} 1 \mathrm{~b}$ and $\mathrm{N4}$, another expense project would reroute the new pipelines (currently going from C-106 to AY-102) to AZ-101 or AZ-102, respectively. The new project also moves pumps and other equipment. For either alternative, a poor expense profile is projected in FY 1996. Figures A-2 and A-3 (see Appendix A) indicate that an additional $\$ 7$ million expense expenditure in FY 1996 is necessary to reroute the pipelines. These two alternatives are significantly more expensive in total cost than the others with the same value (about $\$ 70$ million compared to $\$ 30$ million).

\subsubsection{Risk Analysis: Alternative 7b, 75-hp Mixer Pump} in AY-102, with In-Tank Evaporation

Alternative 7b, the 75-hp Mixer Pump in AY-102, with in-tank evaporation, appears to be the preferred alternative. The risks associated with this alternative are 1 isted below. 
WHC-SD-WM-ER-532

Revision 0

The 75-hp mixer pump in AY-102 is a time-intensive alternative. It is important to move quickly to specify, obtain, and install another mixer pump for AY-102 as soon as possible. The DOE Secretarial Initiative date of October 1996 for startup of C-106 retrieval was estimated to be met in this analysis, based on equipment being available to remove and store the inoperable 75-hp mixer pump in AY-102.

The tank bump (and criticality) USQs will need to be resolved before slurry is moved into AZ-101. This slurry transfer to AZ-101 should begin by about October 1996. The major risks are outlined in the bulleted items as follows:

Revising existing SARs to allow mixer pumps to become tank bump mitigating devices

Obtaining SAR revisions to allow other mitigating features, such as increased annulus airflow in AZ-101.

A possible drawback to Alternative $7 \mathrm{~b}$, and most other alternatives that consolidate sludge in $A Z-101$, is that it may be necessary to revise a portion of the mixer system in AZ-101 to obtain a safety-class system. This would ensure continued operation in case of single point failure. An example of such a system is the safety-class control system installed for the SY-101 mixer pump. The cost of annulus or control modifications was not included in any of the cost estimates. The major USQ analys is for the SAR revision was included. It is probable that the technical safety analysis will show that equipment upgrades are not required if ultra-conservative assumptions can be reduced.

One of the safety advantages of having a mixer pump in AY-102 is that the controlled addition of C-106 sludge from AY-102 to AZ-101 is likely to detect (by temperature measurement), and allow mitigation (mixing) of, any tank bump issues/situations before they become serious.

Allow in-tank concentration to be used to concentrate to $12 \mathrm{Ci}$ cesium-137/gal.

This is the preferred concentration method for all alternatives. The alternative to in-tank evaporation of $A Z-102$ supernate is to use the 242-A evaporator to concentrate the $A Z-102$ supernate (A1ternative $7 \mathrm{a}$ ). Alternative $7 \mathrm{a}$ is actually a subset of Alternative $7 \mathrm{~b}$ and differs only in how evaporation is conducted.

Possible interference with the Project $W-320$ retrieval of $C-106$.

A flowsheet analysis may assist in reducing and quantifying this relatively low risk.

Cost and schedule estimates are contained in Appendixes A and B respectively. The schedule for Alternative $7 \mathrm{~b}$ shows that initial supernate and sludge consolidation is complete in FY 2002, and the initial $192 \mathrm{Kgal}$ of 
sludge consolidation in AZ-101 is complete by FY 1998. This timing should be adequate to meet projected HLW disposal needs. Final sludge consolidation (final cleanout of $\mathrm{C}-106$ ) is not complete until FY 2003. Final sludge consolidation in FY 2003 has the capability to add about $36 \mathrm{Kgal}$ of sludge to AZ-101 and bring the total of HLW sludge in AZ-101 to $228 \mathrm{Kgal}$. The total of $228 \mathrm{Kgal} \mathrm{HLW}$ feed is essentially the same as the Planning Case (A)ternative 5a) and should be sufficient for Phase I of HLW vitrification.

In-tank evaporation is mainly a timing issue. It will take about 5 to 6 years to in-tank evaporate AZ-102 supernate. Alternative $7 \mathrm{~b}$ is less sensitive to this timing issue than the more complicated alternatives because it does not require. new large mixer. pumps and their corresponding project priority concerns, design, and procurement cycles. In-tank evaporation appears to be feasible and ends in about FY 2002, well within the FY 2005 end date needed by waste volume projections.

\subsubsection{Risk Analys is Alternative $\mathrm{N3}$, Botton Sludge Transfer}

The other leading alternative, Bottom Sludge Transfer to AZ-101 (N3), scores a little lower on the value system and is really a default alternative to Alternatives $7 \mathrm{~b}$ and $7 \mathrm{a}$. Alternative $\mathrm{N3}$ could be performed if for some reason the mixer pump in AY-102 became inoperable. Sludge could be transferred to $A Z-101$ using the bottom sludge transfer process.

The bottom sludge transfer process is highly dependent on timing, operation, and design of the $\mathrm{C}-106$ retrieval system. For example, loss of the transfer pump in $A Y-102$ at a critical time could allow the $C-106$ sludge to settle before the transfer pump could be replaced, causing significant reduction of the amount of $\mathrm{C}-106$ sludge transferred to $A Z-101$. Assuming the bottom sludge transfer from AY-102 works as anticipated, Alternative N3 would provide from 105 to $135 \mathrm{Kgal}$ of sludge to HLW disposal. This is about $60 \%$ of the sludge for feed to HLW vitrification obtained in the Planning Case

(Alternative 5a). The schedule is about the same for Alternative $N 3$ as it is for Alternative $7 a$.

Alternative $\mathrm{N} 3$ can be improved in the same way as was Alternative 7a, by changing to in-tank concentration instead of 242-A evaporator concentration. This would improve its overall value about 0.04 and make it the second best alternative overall. 
WHC-SD-WM-ER-532

Revision 0

\subsection{CONCLUSIONS AND RECOMAENDATIONS}

Based on the above decision analys is process, it is concluded that Alternative 7b, 75-hp Mixer Pump Replacement in AY-102 (using in-tank evaporation of AZ-102 supernate), is the preferred alternative. It provides adequate HLW feed to proposed disposal pilot plants in an acceptable time frame. It provides tank space. Risks are manageable. Alternatives to this base case are numerous.

Installing a 75-hp Mixer Pump in AY-102 and replacing the existing inoperable one gives operations increased control of the sludge transport process. The transport of C-106 solids to AZ-101 from AY-102 becomes much more effective than relying on other mixing or mass transfer equipment (ALCS or bottom sludge transfers). By providing a mixer in AY-102, this alternative provides an additional control and mass transfer device to process sludge and manage potential hot spots in tank AY-102.

The next best alternative (fallback) is the modified Alternative N3, Bottom Sludge Tranfer to AZ-101 and in-tank evaporation of AZ-102 supernate. Alternative N3 will transfer as much $\mathrm{C}-106$ sludge from AY-102 to AZ-101 as possible, by using the bottom transfer system as the sludge settles. This alternative is a natural fallback if the mixer in AY-102 would become inoperable for any reason.

The following recommendations are made.

1. Modify the existing 75-hp mixer pump design in AY-102 and obtain the pump for the application. Any other burial equipment required to remove and dispose of the old pump should be designed and obtained. Some or all of this disposal equipment is available onsite. A pump for this application is also probably onsite. The pump will require redesign and modification. Depending on the requirement of HLW vitrification to have feed equal to that of Alternative N3, a back-up pump should be obtained to permit mixing in AY-102 if the new pump should become inoperable.

2. Initiate USQ evaluations for tank bump avoidance scenarios in AZ-101. At least two alternatives are available. One uses the mixer pumps in AZ-101 as mitigation devices. The other alternative uses increased annulus flow in $A Z-101$ as a tank bump mitigation device. Initially, about $75 \%$ of the heat load and sludge volume from $\mathrm{C}-106$ could be used as a design basis.

3. Modify the design of Project W-320 slurry distributor for AY-102. The slurry distributor needs to be able to preferentially place solids in the immediate vicinity of the AY-102 transfer pump. The Project $W-320$ slurry distributor is ready for installation using the original design. 
WHC-SD-WM-ER-532

Revision 0

4. Sample $A Z-101$ and $A Z-102$ supernate and perform a boildown in the laboratory to ensure that precipitation will not occur before achievement of $6.5 \mathrm{M}$ to $7 \mathrm{M}$ sodium concentration. Also, evaluate the potential need for a USQ for modifying the $5 \mathrm{~N}$ sodium OSD for aging waste supernate. Start evaporation of the AZ-102 aging waste supernate as soon as possible after confirming that precipitation will be limited.

5. Revise criticality prevention specifications to allow consolidation of waste to $A Z-101$.

6. Revise/modify tank heat-up rates of $<1.6{ }^{\circ} \mathrm{C} /$ day $\left(<3{ }^{\circ} \mathrm{F} /\right.$ day $)$ as given in the IOSR. Mixer pumps need to be able to be run long enough to mix and transport waste, and to release/move hot spots in the sludge, especially in tank AZ-101.

7. Planning for this base case should be implemented immediately. This should include flowsheet revisions and modifications in the planned recovery of $\mathrm{C}-106$ sludge. These modifications may include a settle/decant process in tank AZ-101 instead of tank AY-102. 
WHC-SD-WM-ER-532

Revision 0

\subsection{REFERENCES}

Aguirre, Jr., H., I995, 242-A Evaporator/Crystallizer Final Safety Analysis Report, WHC-SD-WH-SAR-023, Rev. 2, Westinghouse Hanford Company, Richland, Washington.

Alumkal, W. T., 1995, Multi-Function Waste Tank Facility - Decision Paper (letter 9550111 to T. R. Sheridan, January 13), West inghouse Hanford Company, Richland, Washington.

Awadal la, N. G., 1995, Nulti-Function Waste Tank Facility, Phase Out Basis, WHC-SD-W236A-ER-021, Rev. 0, West inghouse Hanford Company, Richland,
Washington.

Bacon, R. F., 1995, Double-Shell Tank Waste Consolidation and Retrieval Planning Base Case (internal memo 73510-95-017 to C. A. August ine et al., August 29), Westinghouse Hanford Company, Richland, Washington.

Bailey, J. W., 1995, Functional Design Criteria for Tank 241-C-106 Waste Retrieval, Project W-320, WHC-SD-W320-FDC-001, Rev. 3, West inghouse Hanford Company, Richland, Washington.

Castaing, B. A., 1994, 101-AY, 102-AY, \& 106-C Data Compendium, WHC-SD-WM-TI-578, Rev. 1, West inghouse Hanford Company, Richland,
Washington.

DOE, 1988, Radioactive Waste Managenent, DOE Order 5820.2A, U.S. Department of Energy, Washington, D.C.

DOE-RL, 1993, Tank Waste Remediation Systems Functions and Requirements, DOE/RL-92-60, Rev. 1, U.S. Department of Energy, Richland Operations Office, Richland, Washington.

Ecology, EPA, and DOE, 1994, Hanford Federal Facility Agreement and Consent Order, as amended, Washington State Department of Ecology,

U.S. Environmentai Protection Agency, and U.S. Department of Energy, Olympia, Washington.

Eiholzer, C. R., 1994, TWRS Systens Engineering Desk Instruction, WHC-IP-1101, TWRS-SE-04, "Trade Study/Decis ion Analys is," West inghouse Hanford Company, Richland, Washington.

Gasper, K. A, , 1995, Tank Waste Renediation Systen Waste Pretreatment Glossary, WHC-SD-WH-TI-692, Rev. 0, West inghouse Hanford Company, Richland, Washington.

Hanlon, B. M., 1995, Waste Tank Sumary Report for Month Ending March 31, 1995, WHC-EP-0182-84, Westinghouse Hanford Company, Richland, Washington.

Harris, J. P., 1995, Operating Specifications for the 24I-AN, AP, AN, AY, AZ \& SY Tank Farms, OSD-T-151-00007, Westinghouse Hanford Company, Richland,
Washington. 
WHC-SD-WM-ER-532

Revision 0

Hodgson, K. M., 1995, Tank Characterization Report for Double-Shell Tank 241-AZ-101, HHC-SD-WM-ER-410, Rev. 0, West inghouse Hanford Company, Richland, Washington.

Jensen, R. D., 1994, Enhanced Sludge Washing Evaluation Plan, WHC-EP-0805, Westinghouse Hanford Company, Richland, Washington.

Keeney, R. L., and H. Raiffa, 1976, Decisions with Nultiple Objectives: Preferences and Value Tradeoffs, John Wiley \& Sons, New York.

Koreski, G. M., and J. N. Strode, 1995, Operational Waste Volume Projection, WHC-SD-WM-ER-029, Rev. 21, West inghouse Hanford Company, Richland, Washington.

Krantz, D. H., R. D. Luce, P. Suppes, and A. Tversky, 1971, Foundations of Measurenent, vol. 1, Academic Press, New York.

MacLean, G. T., 1995, Caustic for C-106 Leaching (cc:Mail message to W. J. Powe11, September 28), West inghouse Hanford Company, Richland, Washington.

Maclean, G. T., and W. J. Powe11, 1995 (personal communication to W. J. Powel1, November 20), West inghouse Hanford Company, Richland, Washington.

Powel1, N. J., 1995, Concentration of Low-level Waste (LLW) Feed Using the Predict Model (internal letter 71210-95-005 to R. M. Orme and L. M. Swanson, March 23), Westinghouse Hanford Company, Richland, Washington.

Ryan, G. W., 1995a, Tank Characterization Report for Double-Shell

Tank 241-AY-102, WHC-SD-WM-ER-454, Rev. 0, Westinghouse Hanford Company, Richl and, Washington.

Ryan, G. W., 1995b, Tank Characterization Report for Double-Shell

Tank 241-AZ-102, WHC-SD-WM-ER-411, Rev. 0, Westinghouse Hanford Company, Richland, Washington.

Sederburg, J. P., 1994, Chenical Coupatibility of Tank Wastes in 241-C-106, 241-AY-101, and 241-AY-102, WHC-SD-MM-ES-290, Rev. 2, Hestinghouse Hanford Company, Richland, Washington.

Vienna, J. D., and P. R. Hrma, 1995, Glass Formulation for Phase I High-Level Waste Vitrification (this document does not have a number), Pacific Northwest Laboratory, Richland, Washington.

Voge1, R. E., 1994, Results for Tank 241-AY-101 (internal memo 8E480-94-108 to J. M. Jones, October 19), Westinghouse Hanford Company, Richland, Washington.

Von Neumann, J., and 0. Morgenstern, 1947, Theory of Games and Economic Behavior, Princeton University Press, Princeton, New Jersey. 
WHC-SD-WM-ER-532

Revision 0

WHC, 1995a, Decision Management (Interim), WHC-IP- TSEP-07, Rev. 0, Westinghouse Hanford Company, Richland, Washington.

WHC, 1995b, A7ternative Generation and Selection (Interim), WHC-IP-_ TSEP-03, Rev. 0, Westinghouse Hanford Company, Richland, Washington.

Winkler, C. M., 1995, Tank 241-AZ-101 Steam Bumping and Settling Process Test Report, WHC-SD-WM-PTR-012, Rev. 0, Westinghouse Hanford Company, Richl and, Washington. 
WHC-SO-WM-ER-532

Revision 0

This page intentionally left blank. 
WHC-SD-WM-ER-532

Revision 0

\subsection{BIBLIOGRAPHY}

Anderson, C. L., 1992, Process Test Report for the Ninety-Day Rule in Aging Waste Tanks, WHC-SD-WM-TRP-066, Rev. 0, Westinghouse Hanford Company, Richland, Washington.

Barton, W. B., G. T. MacLean, C. D. Meng, and C. M. Winkler, 1995, Status and Progress in Sludge Washing: A Pivotal Pretreatment Method, WHC-SA-2696-FP, Westinghouse Hanford Company, Richland, Washington.

Baungartner, W. V., 1991, Aging Waste Facility Safety Analysis Report, WHC-SD-HS-SAR-010, Rev. 1, West inghouse Hanford Company, Richland, Washington.

Bendixsen, R. B., 1990, History of Tank Bumps in Aging Waste Tank Farms, WHC-SD-WM-TA-021, Rev. 0, Westinghouse Hanford Company, Richland, Washington.

Bergmann, D. W., 1989, Transuranic Removal from Cladding Removal Waste (meeting minutes dated February 22), Westinghouse Hanford Company, Richland, Washington.

Bergmann, L. M., 1989, Process Test Plan for the Ninety-Day Rule in Aging Waste Tanks, WHC-SO-WM-PTP-022, Westinghouse Hanford Company, Richland, Washington.

Bergmann, L. M., 1994, Operating Specifications for the 241-A-702 Vessel Ventilation Systen, OSD-T-151-00016, Westinghouse Hanford Company, Richland, Washington.

Bergmann, L. M., 1994, Operating Specifications for Aging-Waste Operations in 241-AY and 241-AZ, OSD-T-151-00017, Westinghouse Hanford Company, Richland, Washington.

Biume, J. A. \& Associates, 1980, Seismic Design Criteria for Evaluation and Upgrading Studies of Existing Structures and Equipment, RHO-R-17, Rockwell Hanford Operations, Richland, Washington.

Boomer, K. D., 1994, Tank Waste Renediation Systen Facility Configuration Study, WHC-SD-WM-ES-295, Rev. O, Westinghouse Hanford Company, Richland, Washington.

Certa, P. J., 1995, Review of MiNT Path Fonward Engineering Analysis Technical Task 3.8, Retrieval Sequence, WHC-SD-W236A-ES-011, Rev. 0, West inghouse Hanford Company, Richland, Washington.

Certa, P. J., 1995, Select Retrieval Sequence and Blending Strategy Decision Analysis Frane, WHC-SO-WM-RPT-107, Rev. 0, Westinghouse Hanford Company, Richland, Washington.

Colburn, R. P., 1995, Identification of Potential Transuranic Waste Tanks at the Hanford Site, WHC-SD-WM-ES-331, Rev. 0, Westinghouse Hanford Company, Richland, Washington. 
WHC-SD-WM-ER-532

Revision 0

Conner, J. C., 1995, Draft Safety Assessment for C-106 Solids Transfer, West inghouse Hanford Company, Richland, Washington.

DOE, 1988, Radioactive Waste Management, DOE Order 5820.2A, U.S. Department of Energy, Washington, D.C.

Dove, T. H., 1990, Thermal Creep and U1timate Load Analysis of the 241-AY-AZ Reinforced Concrete Underground Waste Storage Tank, WHC-SD-RE-TI-041, Westinghouse Hanford Company, Richland, Washington.

Eggers, R. F., 1995, Requirenents for Mixer Pump Performance and Testing (white paper to Oistribution dated May 30), Westinghouse Hanford Company,
Richland, Washington.

Ferlan, K. B., 1994, Letter Report Tank 241-C-106 Sluicing Project W320 - May 1993, WHC-SD-WH-ES-234, Rev. 2, West inghouse Hanford Company, Richland, Washington.

Fineman, M. I., 1984, Compilation of Basis Letters Referenced in OSD-T-151-00017, SO-RE-TI-064, ReV. 0, Rockwell Hanford Operations, Richland, Washington.

Foster, J. L., 1991, Compilation of Basis Letters Referenced in Double Shell Tank Process Specifications, WHC-SD-RE-TI-008, Rev. 5, West inghouse Hanford Company, Richland, Washington.

Fowler, K. D., 1995, Data Quality Objectives for Tank Farns Waste Compatibility Progran, WHC-SD-Wl-000-001, Rev. 1, Westinghouse Hanford Company, Richland, Washington.

Fukumoto, D. W., 1993, Project W-058 Engineering Study (for Cross-site Transfer Lines), WHC-SD-W058-ES-001, Rev. 0, Westinghouse Hanford Company, Richland, Washington.

Gasper, K. A., 1995, Tank AZ-101 Mixer Pump/Sludge Washing Integrated Process Test Tean (internal memo 9551289 to L. Erickson, March 7), Westinghouse Hanford Company, Richland, Washington.

Grams, W. H., 1995, Double-Shell Tank Retrieval Allowable Heel Trade Analysis, WHC-SD-WM-TA-162, Rev. 0, West inghouse Hanford Company, Richland, Washington.

Hampsten, K. L., 1993, Project W-211 Initial Tank Retrieval Systems Engineering Report, WHC-SD-W211-ES-001, Rev. 0, West inghouse Hanford Company, Richland, Washington.

Hanson, A. G., S. C. Hines, and M. E. Lakes, 1994, Tank Waste Renediation System Transfer Facility Conpliance Plan, WHC-SD-WH-EV-094, Rev. 0, Westinghouse Hanford Company, Richland, Washington.

Heubach, E. C. II, 1995, Aging Waste Facility Interin Operational Safety Requirenents, WHC-SD-WH-OSR-004, Rev. 1, West inghouse Hanford Company, Richland, Washington. 
WHC-SD-WH-ER-532

Revision 0

Jo, J., 1991, The History and Existing Evaluations of the Tank Bump, WHC-SD-WM-TI-406, Rev. O, West inghouse Hanford Company, Richland, Washington.

Jones, B. L., 1988, Aging Waste Tank Bump Sensitivity to Thermal Conductivity and Heat Capacity, Incorporating the Assumption of $N$-Reactor Shutdown (internal memo 13314-88-086 to L. A. Mihalik, May 16), Westinghouse Hanford Company, Richland, Washington.

Kidder, R. J., 1996, Replacement of the Cross-Site Transfer System Preliminary Safety Analysis Report, WHC-SD-N058-PSAR-001, Rev. 1, Westinghouse Hanford Company, Richland, Washington.

Kinzer, J. E., 1995, Multi-Function Waste Tank Facility-Project W-236A Decision Paper (internal memo 95-TOP-027, March 17), U.S. Department of Energy, Richland Operations Office, Richiand, Washington.

Kirch, N. W., 1982, The Winety-Day Rule for Aging Waste Processing, SD-WM-TI-061, Rockwell Hanford Operations, Richland, Washington.

Kirch, N. W., 1987, Hanford Waste Tank Sluicing History, WHC-SD-WM-TI-302, Rev. O, Westinghouse Hanford Company, Richland, Washington.

Kirch, N. W., 1991, Technical Basis for Waste Tank Corrosion Specifications, WHC-SD-WM-TI-150, Rev. 0, West inghouse Hanford Company, Richland, Washington.

Kronva11, C. M., 1982, Maximum Heat Generation and Isotopic Activity Within An Aging Waste Tank, SD-WM-TI-047, Rockwell Hanford Operations, Richland, Washington.

Lawler, J. H., 1982, Direct Neutralization Parameters for PUREX High-Level Wastes, SD-WM-TI-050, Rockwe11 Hanford Operations, Rich Tand, Washington.

Light, J. M., 1991, Conceptional Design Report. Project W058 Replacement of the Cross-Site Transfer, WHC-SD-N058-CDR-001, Rev. 0, Westinghouse Hanford Company, Richland, Washington.

MacLean, G. T., 1995, In-Tank Processing of Hanford Wastes (internal memo 74620-95-018 to J. S. Garfield, May 19), Hestinghouse Hanford Company, Richland, Washington.

Maclean, G. T., 1995, Draft Tank AZ-101 Decant and Refill Test Plan, WHC-SD-WM-PTP-028, West inghouse Hanford Company, Richland, Washington.

Manual, A. F., 1995, TRU Waste Volune Projections (internal memo 75520-95-005, Rev. 1, to T. W. Crawford and W. J. Powe11, June 12), Westinghouse Hanford Company, Richland, Washington.

Mattichak, R. W., 1995, Compliance Plan Requirenents Meeting in Support of Project $\mathrm{W}-314$ (DON'T SAY IT-Write It! 95-RWM-003 to D. Al ison and J. Thurman, June 29), Westinghouse Hanford Company, Richland, Washington. 
WHC-SD-WM-ER-532

Revision 0

Mulkey, C. H., 1995, Double-Shell Tank Waste Analysis Plan, WHC-SD-WM-EV-053, Rev. 3, Westinghouse Hanford Company, Richland, Washington.

Nguyen, D. M., 1989, Waste Streans Compatible with NCRW Solids (DON'T SAY IT-Write It! to D. C. Riley, August 2), Westinghouse Hanford Company, Richland, Washington.

Parsons, G. L., 1995, Functional Design Criteria for Project W-058, Replacenent of Cross-Site Transfer Systen, WHC-SD-W058-FDC-001, Rev. 3, Westinghouse Hanford Company, Richland, Washington.

Pines, A. G., 1991, 244-AR Vault Safety Analysis Report, WHC-SD-WM-SAR-018, Rev. 0, Westinghouse Hanford Company, Richland, Washington.

Powe11, W. J., 1995, Concentration of Low-level Waste (LLW) Feed Using the Predict Model (internal letter 71210-95-005 to R. M. Orme and L. M. Swanson, March 23), Nestinghouse Hanford Company, Richland, Washington.

Rasmusen, 0. R., 1980, Hanford Radioactive Tank Cleanout and Sludge Processing, RHO-ST-30, Rockwell Hanford Operations, Richland, Washington.

Reynolds, D. A., 1988, Viscosity of Evaporator Slurries (internal memo 13314-88-105 to M. C. Teats, June 30), Westinghouse Hanford Company, Richland, Washington.

Reynolds, D. A., 1994, Evaluation of Specific Gravity Versus Gas Retention (internal memo 7E310-94-024 to N. W. Kirch, June 20), West inghouse Hanford Company, Richland, Washington.

Rieck, C. A., 1994, Conceptual Design Report, Initial Tank Retrieval Systems for Project W-211, WHC-SD-W211-CDR-001, Rev. 0, West inghouse Hanford Company, Richland, Washington.

Rieck, C. A., 1995, Functional Design Criteria, Project W-211, Initial Tank Retrieval Systens, WHC-SD-W211-FDC-001, Rev. 1, Westinghouse Hanford Company, Richland, Washington.

Rieck, C. A., 1995, Conceptual Design Report, Initial Tank Retrieval Systens for Project $\mathrm{W}-211$, WHC-SD-W211-CDR-002, West inghouse Hanford Company, Richland, Washington.

Rieck, C. A., 1995, Title I Design Sumary Report, Initial Tank Retrieval Systens, Project W-211, WHC-SD-W211-TDR-001, Rev. 0, Westinghouse Hanford Company, Richland, Washington.

Riley, D. C., 1982, Tenperature Increase Caused by Solids Settling into Corners of Boiling Waste Tanks, SD-WM-TI-055, Rockwell Hanford Operations, Richland, Washington.

Roach, H. L., 1992, Tank 241-101-AZ Project V-151 Equipment Disposal/Storage Requirements Study, WHC-WS-W151-ES-001, Rev. 0, Westinghouse Hanford Company, Richland, Washington. 
Rogers, C. A., 1994, CSER 94-001 Criticality Safety of Single Shell Waste storage Tanks, WHC-SD-SQA-CSA-20363, Rev. 0, West inghouse Hanford Company, Richiand, Washington.

Sathyanarayana, K., M. J. Thurgood, and B. C. Flyer, 1993, Development of a Dynamic Computer Simulator for Aging Waste Tank Operations and Safety Assessment, WHC-SD-WM-ER-198, Rev. 0, West inghouse Hanford Company, Richland, Washington.

Smith, G. L., 1995, Hanford Site Tank Farn Facilities Interim Safety Basis, WHC-SD-WH-ISB-001, vo1. 1, Rev. 0-E, West inghouse Hanford Company, Richland, Washington.

Squires, D. J., 1991, Aging-Waste Facility Safety Analysis Report, WHC-SD-HS-SAR-010, Rev. 2, West inghouse Hanford Company, Richland, Washington.

Szendre, S. A., 1992, Bibliography of Docunents Related to Waste Tank Integrity and Pisces Data Sheets C0016 and C0015-1, WHC-SD-WM-TI-015, Rev. 0, West inghouse Hanford Company, Richland, Washington.

Tulberg, D. M., 1982, Purex Decladding Waste Transfer Pressure Drop Calculations, SO-WM-TI-039-RHO, Rockwe11 Hanford Operations, Richland, Washington.

Tulberg, D. M., 1985, Magnesium Hydroxide Meutralization of Coating Removal Waste (internal meno 65611-85-041 to R. A. Wi11iams, March 7), Rockwe11 Hanford Operations, Richland, Washington.

Tulberg, D. M., 1986, Waste Management Issues Associated with TRU Removal studies (DOW'T SAY IT--Write It! to D. R. Bratzel, October 6), Rockwell Hanford Operations, Richland, Washington.

Tusler, L. A., 1995, Double-Shell Tanks Plutonium Inventory Assessment, WHC-SD-WM-TI-640, Rev. O, Westinghouse Hanford Company, Richland, Washington.

Unek, A. M., 1995, Request to Include Selected Tank Retrieval in Planning Base (white paper to J. 0. Honeyman, May 22), Nestinghouse Hanford Company, Richland, Washington.

Vail, T. S., 1995, Criticality Prevention Specifications, Waste Stored in Double-She17 Tanks and Associated Equipwent, CPS-T-149-00010, Rev. F-0, West inghouse Hanford Company, Richland, Washington.

Venetz, T. J., 1982, Compilation of Basis Letters Referenced in 241-AN, AN, $A Y, A Z$, and SY Process Specifications, SD-RE-TI-0089, Rev. 2, Rockweli Hanford Operations, Richland, Washington.

Walser, R. L., 1986, Cladding Renoval Waste (meeting minutes dated August 7), Rockwe 11 Hanford Operations, Richland, Mashington. 
Walter, E. J., 1995, Double-Shell Tank Waste System Assessment Status and Schedule, WHC-SD-WM-ETP-153, Rev. 0, Westinghouse Hanford Company, Richland, Washington.

Waters, E. D., 1993, Tank 101-AZ Waste Retrieval System, WHC-SD-W151-FDC-001, Rev. 2, Westinghouse Hanford Company, Richland, Washington.

Weiss, R. L., and K. E. Schull, 1992, Data Transmittal Package for 241-C-106 Waste Tank Characterization, WHC-SD-RE-TI-205, Rev. 0, West inghouse Hanford Company, Richland, Washington.

WHC, 1994, Hazard and Accident Analysis, WHC-SD-WM-SAR-065, Rev. 0, West inghouse Hanford Company, Richiland, Washington.

WHC, 1994, Operating AY and AZ Airlift Circulators, T0-200-030, Westinghouse Hanford Company, Richland, Washington.

WHC, 1995, Draft-Tank Fari Accelerated Safety Analysis, WHC-SD-WM-SAR-065, Rev. A, West inghouse Hanford Company, Richland, Washington. 
WHC-SD-WH-ER-532

Revision 0

\section{0 gLOSSARY}

\subsection{ABBREYIATIOUS AD ACROWYHS}

$\begin{array}{ll}\text { ALC } & \text { air-lift circulator } \\ \text { AWT } & \text { aging waste tank } \\ \text { DOE } & \text { U.S. Department of Energy } \\ \text { DSSF } & \text { double-shell slurry feed } \\ \text { DST } & \text { double-shell tank } \\ \text { F\&R } & \text { functions and requirements } \\ \text { FY } & \text { fiscal year } \\ \text { HLW } & \text { high-level waste } \\ \text { IOSR } & \text { Interim Operational Safety Requirements } \\ \text { LLW } & \text { low-level waste } \\ \text { NCAW } & \text { neutralized current acid waste } \\ \text { OSD } & \text { operating specification docunentation } \\ \text { OSR } & \text { operating safety requirements } \\ \text { PUREX } & \text { plutonium uraniun reduction and extraction } \\ \text { REDOX } & \text { reduction and oxidation } \\ \text { SAR } & \text { safety analysis report } \\ \text { SST } & \text { single-shell tank } \\ \text { TCR } & \text { Tank Characterization Report } \\ \text { TOC } & \text { total organic carbon } \\ \text { TRU } & \text { transuranic } \\ \text { TWRS } & \text { Tank Waste Remediation System } \\ \text { USQ } & \text { unresolved safety question }\end{array}$

\subsection{DEFINITIONS}

Aging Waste. High-level, first-cycle solvent extraction waste from the Plutonium-Uranium Extraction Plant, following evaporative concentration, denitration, and neutralization. Also called neutralized current acid waste.

Bottom decant. A transfer of solids in a slurry using only the deep well turbine transfer pump in AY-102. A slurry may be released in the tank above the pump to assist in the transfer. Transfers of solids occur without mobilization of the sludge by other means, such as a mixer pump.

Caustic leaching. Use of caustic solution to dissolve sludge components. Components targeted for separation by caustic washing include aluminum, chromium, and phosphorus. This is one part of the enhanced sludge-washing process.

Decant. To pour or drain off a liquid without disturbing the sediment.

Double-She11 Slurry Feed (DSSF). Waste concentrated just before reaching the sodium aluminate saturation boundary (usually of 6.5 to 7 molar hydroxide) in the evaporator without exceeding receiver tank composition limits. The DSSF is not as concentrated as double-shell slurry.

Evaporation. To draw moisture from, leaving a concentrated solution or solids portion. 
WHC-SD-WM-ER-532

Revision 0

In-Tank Processing. Performance of processing within extsting Hanford Site double-shell tanks.

Leaching. The process of removing a solute from a solid by using a liquid solvent.

Low-Level Waste. Any gaseous, 1 iquid, or solid waste that contains radioactivity and is not classified as high-level waste, transuranic waste, or spent nuclear fuel or $11 \mathrm{e}(2)$ byproduct material as defined by

DOE Order 5820.2A, Radioactive Waste Managenent (DOE 1988).

Mixing Sludge. An operation that combines or blends the waste before slurry transfer.

Sludge. Water-insoluble solids that settle and accumulate at the bottom of a storage tank at the Hanford Site. Solids are formed by precipitation or self-concentration, and are metal hydroxides and oxides precipitated during sodium hydroxide additions to waste.

Sludge Nashing. Operation that uses weak caustic to dissolve the readily soluble solids (sodium salts) and dilute the concentration of dissolved salts in the interstitial 11quid. This operation minimizes the quantity of salts going to the high-level waste (HLW) vitrification processes, thus minimizing the volume of HLW produced. Weak caustic is used to inhibit corrosion during the washing process. (Also known as water washing.)

Slurry. A combination of suspended solids in a liquid, usually requires a moving liquid to keep the solids suspended. to another.

Slurry Transfer. Moving of solid waste slurry with liquid from one point

Solids Settling. An operation in which the solids settle from a slurry after being transferred into a tank.

Tank Bump. A tank pressurization caused by rapid steam generation.

Total Organic Carbon. A measure value of the anount of carbon from organic compounds in a sample. another.

Transfers. Removal of supernate or solids slurry from one tank to

Iransuranic. Period 7 elements having an atomic number of 93 or greater, i.e., elements that are heavier than uranium in the periodic table.

Iransuranic laste. Without regard to source or form, waste that is contaminated with alpha-emitting transuranic radionuclides with half-lives $>20$ years and concentration $>100 \mathrm{nCi} / \mathrm{g}$ at the time of assay.

Vitrification. A method of immobilizing radioactive waste for eventual disposal in a geologic repository. Involves adding waste and chemical components to a heated vessel and melting it into a glass. 
WHC-SD-WM-ER-532

Revision 0

Wash. To cleanse of particulate constituents through the use of a liquid, usually water. 
WHC-SD-WM-ER-532

Revision 0

This page intentionally left blank. 
WHC-SD-WM-ER-532

Revision 0

APPENDIX A

COST ESTIHATES

A-1 
WHC-SD-WM-ER-532

Revision 0

This page intentionally left blank. 
WHC-SD-WM-ER-532

Revision 0

APPENOIX A

COST ESTIMATES

The following cost estimates are based on the operating scenarios outlined in the main text in Section 3.5.2.2.

\section{NEUTRALIZED CURRENT ACID YASTE CONSOLIDATION COST ESTINATING}

\section{Waste Transfers}

Routing setup: Costs related to transferring waste were obtained from tank farm operations representatives D. Sparks and W. F. Zuroff. The first phase of establishing a transfer route would be to install the required jumpers. Because the major portion of the transfers to be made consists of moving solids and concentrated waste, it was assumed that new, rigid jumpers would be fabricated and installed in the designated process pits.

The field resources required to support process pit entries for jumner and pump installations are assumed to include the following tasks: (1) 1 day for setup, (2) 1 day for installation, and (3) 1 day for area cleanup. The staff hours/personnel support are as follows: riggers/60 staff hours, fitters $/ 8$ staff hours, electricians $/ 8$ staff hours, health physics technicians/ 48 staff hours, operators/96 staff hours, and Quality Control/8 staff hours. For estimating purposes, it was assumed that the average liquidation rate was $\$ 50 / \mathrm{h}$, including program adders. Therefore, the average cost for a pit entry equates to $\$ 11,400$.

The assumptions do not assume that a confinement tent will be required for each pit entry.

For the duration of the transfer operation, it is assumed that two tank farm operations personnel would monitor the activity 24 hours a day.

Waste sample: For each transfer, it was assumed that a waste sample will be required. The unit cost for the sample is $\$ 70,000$. This cost covers field support for removing the sample from the tank, transporting the sample to the laboratory, and conducting the laboratory analysis.

Iransfer rate: It was assumed that the average transfer rate is $100 \mathrm{gpm}^{*}$. A11 transfers are assumed to be operated 24 hours a day, and therefore range in duration from 4 to 14 days.

\footnotetext{
"See the Conversion Table in front matter of document.
} 
WHC-SD-WM-ER-532

Revision 0

\section{EVAPORATION (242-A EVAPORATOR)}

For concentration of supernate waste and decanted sludge-wash solutions, it is assumed that the cost is $\$ 5.54 / g a l$ of throughput. This value was obtained from T. W. Seifert of Tank Waste Remediation System Tank Farm Processing.

\section{REROUTING OF PROJECT $\mathrm{W}-320$ PIPELINES TO AZ-101 OR AZ-102}

Capital cost estimates were prepared for rerouting Project $W-320$ waste transfer 1 ines to waste tanks $A Z-101$ and AZ-102. The estimates were developed using the project cost estimate. It was assumed that a11 construction scope, with the exception of installing the AY-102 in-tank equipment, had been completed for Project $\mathrm{W}-320$. It also was assumed that the transfer system had not been activated and therefore tieing into the transfer system would not be a hot tie-in activity; thus, no burnout would be incurred.

The ICF Kaiser Hanford Company estimates (N3093/Z372SAB2 and N3093/Z372SAAl), found at the end of Appendix A, cover the scope of rerouting the transfer lines. These estimates assumed that the waste transfer system would be tied into at a location west of the AZ Tank Farm and north of the AY Tank Farm.

\section{PROJECT H-211/INITIAL WASTE RETRIEYAL SYSTENS}

Cost estimates for installation of initial retrieval systems in the $A Z-102, A Y-101$, and/or the AY-102 tanks were obtained from Project $W-211$ documentation. The current planning case for Project $\mathrm{W}-211$ assumed that retrieval systems for the aforementioned tanks would not be achieved until fiscal year (FY) 2006 or 2007, and in these cases, the systems depended on the installation of a mixer system in AN-103. This dependency is due to the sharing of the control system building, the transformer supply system, and the caustic supply system. To meet the schedule need dates for consolidation, it is necessary to accelerate the installation of the AZ-102 system to FY 2000; therefore, ICF Kaiser Hanford Company estimate Z2372SAG1 based on Project $\mathrm{W}-211$ for $\mathrm{AN}-103$ was used. It was then assumed that the systems to be provided for either AY-101 or AY-102 would be constructed next and therefore would be able to share common systems as planned by Project $\mathrm{H}-211$. summaries.

Other assumptions are 1 isted in the following individual cost estimate 
WHC-SD-WM-ER-532

Revision 0

\section{UNRESOLVED SAFETY QUESTIOAS (USQ)}

Costs for the alternatives were estimated by discussions with personnel in the Safety Analysis group (K. 0. Fein and W. G. Farley among others), and by discussions with G. T. MacLean for the technical analysis. The following estimates were made based on the following assumptions.

- The (proposed interim operating safety requirements [IOSR]) safety envelope of $102 \mathrm{~cm}$ ( 40 in.) of solids could be extended by analysis to significantly higher sludge levels, as long as the heat content of the sludge was within the $300,000 \mathrm{Btu} / \mathrm{h}$ heat 1 imit.

- Both the 102-cm (40-in.) solids limit and the 300,000 Btu/h limit could be extended beyond existing (proposed IOSR) 1 imits, especially if at least two mixer pumps were installed in the tank as mitigating features to prevent tank bumps.

- A major USQ evaluation requires at least one significant technical evaluation, including calculations, to resolve. It probably has a "yes" answer to one of the eight questions on the USQ form. This issue will be somewhat difficult to resolve and may not be resolvable as desired.

- A minor USQ evaluation is one that does not require a significant technical evaluation. It probably does not involve an answer of "yes" to any of the questions on the USQ form. This issue will be relatively easy to resolve.

- The rough order of magnitude (ROM) cost of a major USQ was estimated to be $\$ 300,000$ and that of a minor USQ about $\$ 100,000$. This was based on current chargeout rates.

- The ROM cost of a typical extensive sludge sample compositional and chemical analysis was estimated to be $\$ 200,000$. This analys is includes a large sample for wash and leach, and slurry transfer testing. The cost estimate was derived from a discussion with Operations staff and G. T. MacLean.

See Tables A-1a, A-1b, and A-2 for numbers of minor and major USQs and their costs.

OPERATING PROCEDURE COST ESTIMATE (December 7, 1995)

\section{Operating Procedures}

Enabling assumptions used to develop cost estimates for the transfer procedures are as follows.

The transfer procedures are included in a Tank Farm plant operating procedure. In general, the procedure provides information such as purpose, scope, definition of terms used, assignment of responsibilities, safety issues related to the transfer, radiation and contamination control issues, quality assurance issues, general information about the transfer, limits and 


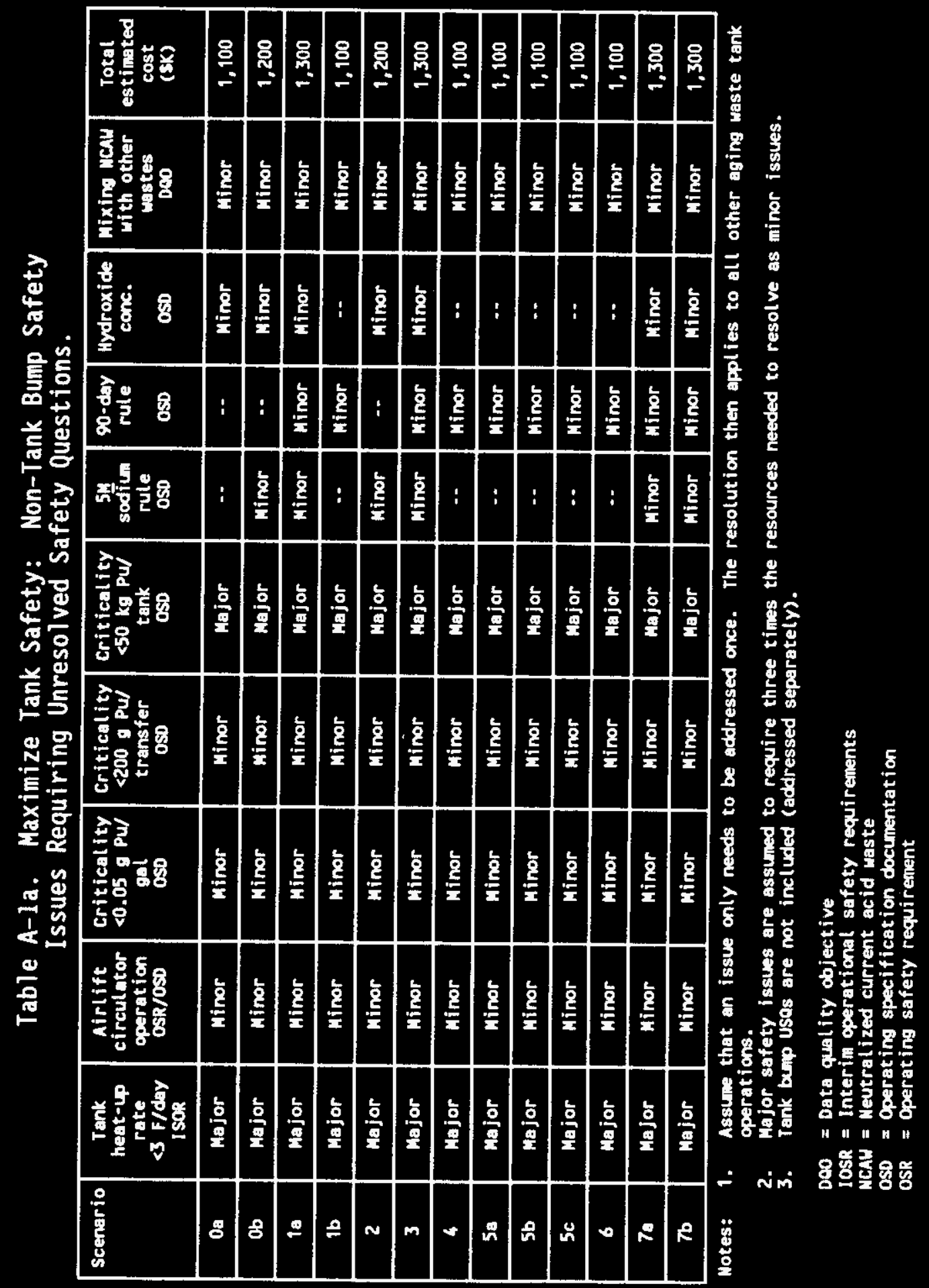




\section{SUMHARY COST ESTIBATE FOR USQ AWALYSIS}

\section{USQ Cost Evaluation}

Table A-1b. Maximize Tank Safety: Non-Tank Bump Safety Issues Requiring Unresolved Safety Questions.

\begin{tabular}{|c|c|c|c|c|c|c|}
\hline Al ternative & $\begin{array}{l}\text { Evaporator } \\
\text { accidint, } \\
>6 \mathrm{ci} / \mathrm{gal}\end{array}$ & $\begin{array}{l}\text { Shielding linit } \\
\text { exceeded on } \\
\text { transfer lines, } \\
>6 \mathrm{ci} / \mathrm{gal}\end{array}$ & $\begin{array}{l}\text { Shiolding } \\
\text { I imit exceeded } \\
\text { at } 242-A_{1}^{*} \\
>3 \mathrm{Ci} / \mathrm{sat}\end{array}$ & $\begin{array}{l}\text { Cost from } \\
\text { Tables } A-1 a \text {, } \\
\text { and } A-1 \text { (sil) }\end{array}$ & $\begin{array}{l}\text { Cost from } \\
\text { this table } \\
\text { (sil) }\end{array}$ & $\begin{array}{c}\text { Total cost, } \\
\text { Tables } A-1 a \\
\text { and } A-1 b \\
\text { (sM) }\end{array}$ \\
\hline $\mathrm{Oa}$ & -- & $\cdots$ & $-\cdot$ & 1.1 & 0 & 1.1 \\
\hline $\mathbf{O b}$ & $\cdots$ & -- & 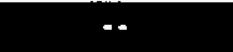 & 1.2 & 0 & 1.2 \\
\hline 10 & Mojor & Minor (2) & Minor (2) & 1.3 & 0.7 & 2 \\
\hline 16 & Major & Minor (2) & Minor (2) & 1.1 & 0.7 & 1.8 \\
\hline 2 & Mojor & Minor (2) & Minor (2) & 1.2 & 0.7 & 1.9 \\
\hline 3 & Major & Minor (2) & Minor (2) & 1.3 & 0.7 & 2 \\
\hline 4 & Major & Minor (2) & Minor (2) & 1.1 & 0.7 & 1.8 \\
\hline $5 a$ & Major & Minor (2) & Minor (2) & 1.1 & 0.7 & 1.8 \\
\hline $5 b$ & Major & Minor (2) & Minor (2) & 1.1 & 0.7 & 1.8 \\
\hline $5 c$ & Major & Hinor (2) & Minor (2) & 1.1 & 0.7 & 1.8 \\
\hline 6 & Major & Minor (2) & Minor (2) & 1.1 & 0.7 & 1.8 \\
\hline $7 a$ & Major & Minor & Minor & 1.3 & 0.7 & 2.0 \\
\hline $7 b$ & Major & -- & -- & 1.3 & 0.0 & 1.3 \\
\hline
\end{tabular}

*Accident scenario derived fron WHC-50-L4-SAR-023, Rev. 2, 242-A Evaporator/Crystallizer Final Safety Anatysis Reoprt, H. Aguirre, Jr., Westinghouse Hanford Company, Richland, Washington, 1995 (see Table 4-19 and Chapter 9, and section 6.7.2.2 for this shielding limit). 
Table A-2. Tank Bump Unresolved Safety Questions and Miscellaneous.

\begin{tabular}{|c|c|c|c|c|c|c|}
\hline Al ternative & $\begin{array}{l}\text { Sludge haight } \\
\text { I0sk, >101 cm } \\
\text { (40 in.) (not } \\
\text { inctuding } \\
\text { AY-102) }\end{array}$ & $\begin{array}{l}\text { sludge heat } \\
\text { content } \\
\text { IOSR, } \\
>306 \mathrm{KBtu} / \mathrm{h}\end{array}$ & $\begin{array}{l}7 \mathrm{H} \text { Na process } \\
\text { test, oso, } \\
\text { s200K/test }\end{array}$ & $\begin{array}{l}\text { sludge } \\
\text { sampling } \\
\text { required, } \\
\text { s200k/sample } \\
\text { and test }\end{array}$ & $\begin{array}{l}\text { Total cost } \\
\text { this table } \\
\text { (SW) }\end{array}$ & $\begin{array}{l}\text { Total cost } \\
\text { all usas and } \\
\text { process test } \\
\text { and semples } \\
\text { (sw) }\end{array}$ \\
\hline Oe & -- & $=$ & - & $\cdots$ & 0 & 1.1 \\
\hline$o b$ & - & -- & 2 & $\cdots$ & 0.4 & 2.3 \\
\hline 18 & Major & -- & 1 & $\cdots$ & 0.5 & 2.5 \\
\hline ib & Major (2) & Major & 0 & -- & 0.7 & 2.5 \\
\hline 2 & $\cdots$ & $\cdots$ & 2 & $\cdots$ & 0.4 & 2.3 \\
\hline 3 & $\begin{array}{c}\text { Minor, }>101 \text { cin } \\
\text { ( } 40 \text { in.) when } \\
\text { fluffed }\end{array}$ & -- & 1 & $\cdots$ & 0.3 & 2.3 \\
\hline 4 & Major (2) & Mojor & 0 & $\cdots$ & 0.9 & 2.7 \\
\hline 58 & Major (3) & Major & 0 & - & 1.2 & 3.0 \\
\hline $5 b$ & Major (4) & Major & 0 & - & 1.5 & 3.3 \\
\hline $5 c$ & Major (4) & Major & 0 & 1 & 1.7 & 3.5 \\
\hline 6 & Major (5) & Major (2) & 0 & 1 & 2.1 & 3.9 \\
\hline $7 a$ & Major (1) & Major (1) & 1 & 0 & 0.8 & 2.8 \\
\hline $7 b$ & Major (1) & Major (1) & 1 & 0 & 0.8 & 2.1 \\
\hline
\end{tabular}

IOSR = Interin operational safety requi rentents

OSD = Oparating specification docunentation

usa = Unresolved safety question

precautions, record keeping of the waste transferred, prerequisites to the transfer, and the transfer procedure. Within the transfer procedure, information is provided for performing transfer valving and pit box cover check, flushing of transfer lines and pumps, and post-transfer valving. Also within the transfer procedure are a transfer control checklist, transfer datasheets, cover installation inspection checklist, temperature monitoring datasheets, a valve position checklist, and a history signature sheet.

From discussions with $D$. W. Reberger, it takes approximately 1 month to develop a transfer procedure with a schematic of the transfer route. Representatives from the following organizations are involved in the development and approval of a transfer procedure: Plant Engineering, Procedure Development, Operations, and Quality Assurance. The Engineering organization needs about 80 hours to develop the transfer route, procedure writers need about 40 hours to write the procedure, Operations needs about 12 hours to walk down the transfer route, and Qual ity Assurance needs about 40 hours to review the transfer procedure.

The cost for the time involved by each organization was found in Soft Reporting. It was found that engineering time would cost approximately $\$ 50 / \mathrm{h}$, the procedure writer would cost about $\$ 52 / \mathrm{h}$, Operations would cost about $\$ 48 / \mathrm{h}$, and Quality Assurance would cost about $\$ 49 / \mathrm{h}$. 
The number of transfers required for each alternative was taken from Section 3.5.2.2 of the main text. The enabling assumption used to determine the number of transfers was that a new transfer procedure would be required for all transfers into and out of the double-shell tanks.

To determine development costs of a transfer procedure, the cost for the organizations involved was summed, with a total of $\$ 8,616$. To be conservative, the amount was rounded up to $\$ 9,000$. To determine development costs for the transfer procedures for each alternative, the number of procedures required was multiplied by $\$ 9,000$ (see Table A-3).

Table A-3. Cost Estimates for Required Operating Procedures.

\begin{tabular}{|c|c|c|}
\hline Alternative & Number of transfers required per alternative & Cost \\
\hline \multicolumn{3}{|c|}{ Includes wash and leach steps } \\
\hline $\mathbf{0 a}$ & 10 & $\$ 90,000$ \\
\hline $\mathrm{Ob}$ & 11 & $\$ 99,000$ \\
\hline $1 \mathrm{a}$ & 17 & $\$ 153,000$ \\
\hline 16 & 20 & $\$ 180,000$ \\
\hline 2 & 15 & $\$ 135,000$ \\
\hline 3 & 18 & $\$ 162,000$ \\
\hline 4 & 22 & $\$ 198,000$ \\
\hline $5 \mathbf{a}$ & 24 & $\$ 216,000$ \\
\hline $5 \mathbf{b}$ & 31 & $\$ 279,000$ \\
\hline $5 \mathrm{C}$ & 28 & $\$ 252,000$ \\
\hline 6 & 30 & $\$ 270,000$ \\
\hline 7 & 18 & $\$ 162,000$ \\
\hline \multicolumn{3}{|c|}{ Excludes wash and leach steps } \\
\hline N1a & 12 & $\$ 108,000 *$ \\
\hline Nlb & 13 & $\$ 117,000 *$ \\
\hline 2 & 11 & $\$ 99,000 *$ \\
\hline N3 & 13 & $\$ 117,000 *$ \\
\hline $\mathrm{N4}$ & 13 & $\$ 117,000 *$ \\
\hline N5a & 15 & $\$ 135,000 *$ \\
\hline 7 & 13 & $\$ 117,000 *$ \\
\hline
\end{tabular}

NOTE: The cost for the $C-106 \gg$ AY-102 transfer procedure should be addressed by Project $\mathrm{W}-320$. If this is true, every alternative with this transfer (Alternatives $0 \mathrm{a}, 0 \mathrm{~b}, 2,3,5 \mathrm{a}, 5 \mathrm{~b}, 5 \mathrm{c}$, and 6) will be $\$ 9,000$ less than the cost stated in this tabie.

* Cost estimate has not been updated to reflect cost reductions for non-leach and wash. 
WHC-SD-WM-ER-532

Revision 0

Table A-4. Estimates for Transfer Procedures (Generic).

\begin{tabular}{|l|c|c|c|}
\hline \multicolumn{1}{|c|}{ Job function } & Time required & Rate per hour & Cost \\
\hline Engineering & 2 weeks $=80 \mathrm{~h}$ & $\$ 50$ & $\$ 4,000$ \\
\hline Procedure writer & 1 week $=40 \mathrm{~h}$ & $\$ 52$ & $\$ 2,080$ \\
\hline Operations review & $12 \mathrm{~h}$ & $\$ 48$ & $\$ 576$ \\
\hline Qual ity assurance review & 1 week $=40 \mathrm{~h}$ & $\$ 49$ & $\$ 1,960$ \\
\hline Total cost per transfer procedure $=\$ 8,616 \gg \gg \$, 000$ & \\
\hline
\end{tabular}

Other procedures that may apply to the Neutralized Current Acid Waste/ C-106 consolidation are as follows:

- T0-200-610, "Specific Transfer Procedure 101-AZ to 102-AZ"

- T0-250-550, "Transfer from 204-AR to 102-AY"

- .T0-200-030, "Operate AY \& AZ Air-Lift Circulators"

- T0-020-705, "Flush Salt Well Jet Pump Systems and Transfer Lines"

- OSD-T-151-00030, "Operating Specifications for Watch List Tanks"

- OSD-T-151-00007, "Operating Specifications for 241-AN, AP, AW, AY, and $A Z^{\prime \prime}$

- 2E22013, "Heat Trace Control Test for 241-AY \& AZ Tank Farms."

Rigid Jumper Requirement

A rigid jumper is required when transferring solids, transferring caustic for leaching operations, or when transferring double-she11 slurry feed (DSSF). C. E. Jensen developed a spread sheet that depicts the tank (central pump pits and sluice pits) and the valve pits used for each transfer in each alternative. The spread sheet also shows the location of non-rigid jumpers in the various transfer routes. From this spread sheet, the number of new rigid jumpers was determined (see Table A-5).

\section{ENABLING ASSUNPTIOHS:}

1. Valve pits $A-A, A-B, A X-A, A X-B, A W-A$, and $A W-B$ will require two new rigid jumpers each. This implies that each alternative will require the installation of at least 12 jumpers.

2. The origin of DSSF in Alternatives $1 \mathrm{a}, 5 \mathrm{a}, 5 \mathrm{~b}, 5 \mathrm{c}$, and 6 is undetermined and could come from the AN, AP, or AW tank farms. For this reason, jumper installation in the AN valve pit was considered. Two rigid jumpers would be required in the $A N-A$ and $A N-B$ valve pits (four total) if DSSF is transferred from the AN Farm. 
3. The existing transfer pump in tank AY-102 is operational and will be used.

4. Installation of the mixer pump system in $A Z-101$ is accounted for in Project W-151.

5. Installation of mixer pumps, transfer pumps, and decant pumps requires the installation of one jumper per pump.

6. The AY Farm requires four mixer pumps and one transfer pump, and the AZ Farm requires two mixer pumps and one transfer pump.

7. The number of jumpers installed does not necessarily equal the number of pit entries required for each alternative.

Table A-5. Jumper Installation Required for Neutralized Current Acid Waste Transfer Scenarios (Including Wash and Leach Steps).

\begin{tabular}{|c|c|c|}
\hline $\begin{array}{l}\text { Al ternat ive } \\
\text { Nuber }\end{array}$ & $\begin{array}{l}\text { Nuber of new rigid } \\
\text { jumpers requiring } \\
\text { install lotion (see } \\
\text { section } 3.4 .2 \text { of main } \\
\text { text for details on } \\
\text { transfer routes) }\end{array}$ & Location of jumper installation \\
\hline $\mathrm{Oa}$ & 15 & $\begin{array}{l}241-A-A \text { VP, } 241-A-B \text { VP, } 241-A X-A \text { VP, } 241-A X-B \text { VP, } 241-A U-A \text { VP, } \\
241-A H-B \text { VP, decant PUip 101-AZ, 101-AZ 01A central pup pit, } \\
102-A 2 \text { 02A central pUip pit }\end{array}$ \\
\hline $\mathbf{a b}$ & 15 & $\begin{array}{l}241-A-A \text { VP, } 241-A-B \text { VP, 241-AX-A VP, } 241-A X-B \text { VP, } 241-A U-A \text { VP, } \\
241-A U-B \text { VP, decant pup 101-AZ, 101-AZ 01A central pup pit, } \\
102-A z \text { o2A central pUP pit }\end{array}$ \\
\hline $1 \mathrm{a}$ & 20 & 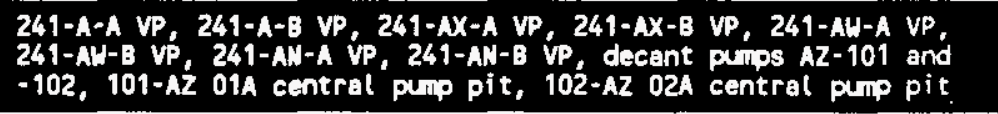 \\
\hline 1b & 18 & $\begin{array}{l}241-A-A \text { VP, } 241-A-B \text { VP, } 241-A X-A \text { VP, } 241-A X-B \text { VP, } 241-A U-A \text { VP, } \\
241-A U-B \text { VP, } 1 \text { decant pup 101-AZ, 101-AZ 01A central pump pit, } \\
102-A Z \text { o2A central pup pit, } 2 \text { mixer pumps and } 1 \text { transfer pump } \\
-102-A Z\end{array}$ \\
\hline 2 & 20 & 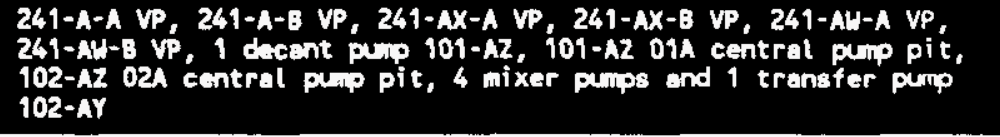 \\
\hline 3 & 16 & 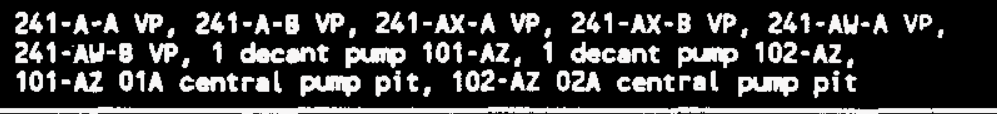 \\
\hline 4 & 18 & 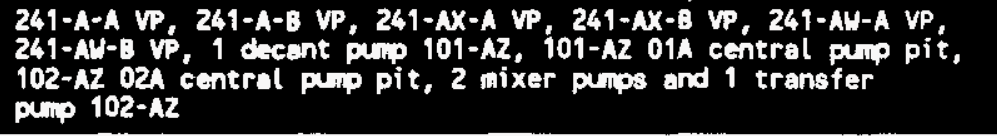 \\
\hline $5 a$ & 22 & 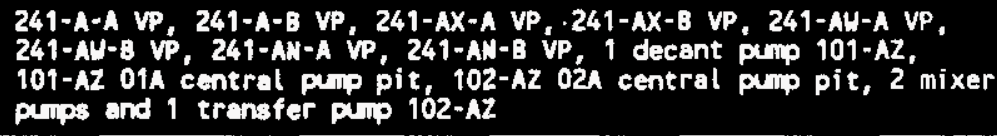 \\
\hline $5 b$ & 27 & 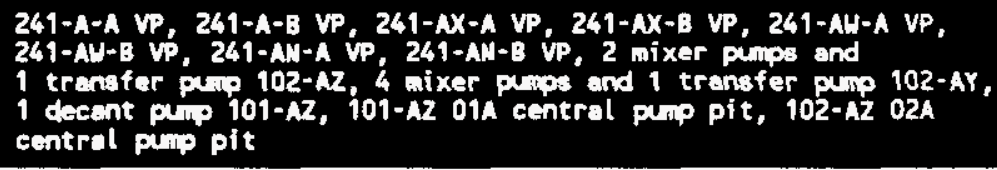 \\
\hline
\end{tabular}


Table A-5. Jumper Installation Required for Neutralized Current Acid Waste Transfer Scenarios (Including Wash and Leach Steps).

\begin{tabular}{|c|c|c|}
\hline $\begin{array}{c}\text { Al ternative } \\
\text { Nunber }\end{array}$ & $\begin{array}{l}\text { Number of now rigid } \\
\text { jumpers reauiring } \\
\text { instal lation (see } \\
\text { Section } 3.4 .2 \text { of main } \\
\text { text for details on } \\
\text { transfer routes) }\end{array}$ & Location of jumper installation \\
\hline $5 \mathrm{c}$ & 27 & 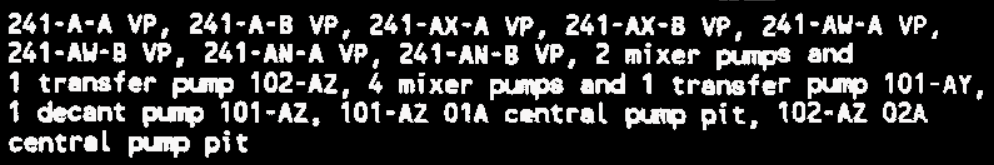 \\
\hline 6 & 30 & 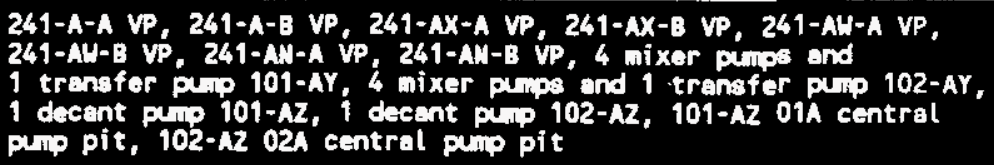 \\
\hline 7 & 17 & 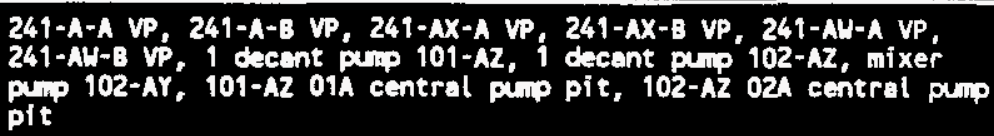 \\
\hline
\end{tabular}

The enabling assumptions used to determine the number of new, rigid jumpers required for each alternative are:

1. To provide flexibility in transferring the waste, the following valve pits will have two rigid jumpers installed: 241-A-A, 241-A-B, 241-AX-A, 241-AX-B, 241-AW-A, and 241-AW-B.

2. Jumper installation was considered for the 241-AN valve pits for A1ternatives $1 \mathrm{a}, 5 \mathrm{a}, 5 \mathrm{~b}, 5 \mathrm{c}$, and 6 because the origin of DSSF was undetermined for these alternatives at the time of development of the number of rigid jumpers required. The DSSF could come from either the AN, AP, or AN Tank Farms. Two rigid jumpers would be installed in the 241-AN-A and 241-AN-B valve pits.

3. Installation of mixer pumps, transfer pumps, and decant pumps requires the installation of one rigid jumper per pump.

4. When a mixer system is called out in Section 3.5.2.2 of the main text, the AY Tank Farm requires four mixer pumps and one transfer pump, and the $A Z$ Tank Farm requires two mixer pumps and one transfer pump.

5. Installation of the mixer pump system in $A Z-101$ is accounted for in Project W-151.

6. The existing transfer pump in tank AY-102 is operational and will be used.

7. The number of rigid jumpers installed does not necessarily equal the number of pit entries required for each alternative. 
WHC-SD-WM-ER-532

Revision 0

\section{Routings}

Figure A-1 provides a depiction of the existing A Farm Complex waste transfer system. The waste routings shown are transfer lines that are currently considered to be regulatory compliant, e.g., pipe-in-pipe, with leak detection. The system consists of underground piping constructed of nominal 2-in. and 3-in. primary 1ines. The 2-in. 1ines are referred to as Slurry lines (SL) and the 3-in. lines are referred to as Supernatant lines (SN).

The current system supports transfers related to SST saltwell pumping, 242-A evaporator operations, and miscellaneous waste transfers from Hanford Site facilities.

Establishing routes to support the consolidation of the NCAN will have to be integrated with the aforementioned tank farm waste transfers and therefore a dedicated routing has not been established. Future studies may be required to identify, design, and fabricate jumpers to support NCAN consolidation and other waste transfers. The goal should be to provide required flexibility in the routes to support all waste transfers and minimize the need for pit entries to change the route setup, e.g., jumper change-outs.

\section{Readiness Review}

The U.S. Department of Energy (DOE) Order 5480.31, Startup and Restart of Nuclear Facilities Operational Readiness Review and Readiness Assessments (DOE 1993), establishes the requirements for operational readiness reviews. Westinghouse Hanford Company implements the DOE Order with WHC-CM-1-5, Standard Operating Practices, Section 1.2, "Operational Readiness Reviews."

The purpose of the operational readiness review is to ensure the adequacy of facilities, equipment, personnel, and administrative systems before the startup or restart of nuclear facilities. The scope and level of approval authority of the readiness review process are determined by the magnitude of the hazards involved and the complexity of the operating facility.

Generally, routine operations and startup from planned maintenance and routine replacement of equipment do not require an operational readiness review. Operations outside the scope of previous DOE approvals and agreements may require a readiness review or at least concurrence from the DOE that a readiness review is not required.

Projects $\mathrm{W}-151, \mathrm{~W}-320$, and $\mathrm{W}-211$ are associated with consolidation of material in the AY and $A Z$ Tank Farms. Each of these projects has readiness review included as a project activity. The readiness review is effectively completed before the equipment and instrumentation associated with the project are turned over to Operations.

\section{Project $\mathrm{W}-151$}

Project $W-151$ adds mixer pumps to $A Z-101$. Project $W-151$ also includes the following:

- Two mixer pumps 
WHC-SD-WM-ER-532

Revision 0

Figure A-1. A Farm Complex Transfer Lines.

A FARM COMPLEX WASTE TRANSFER SYSTEM

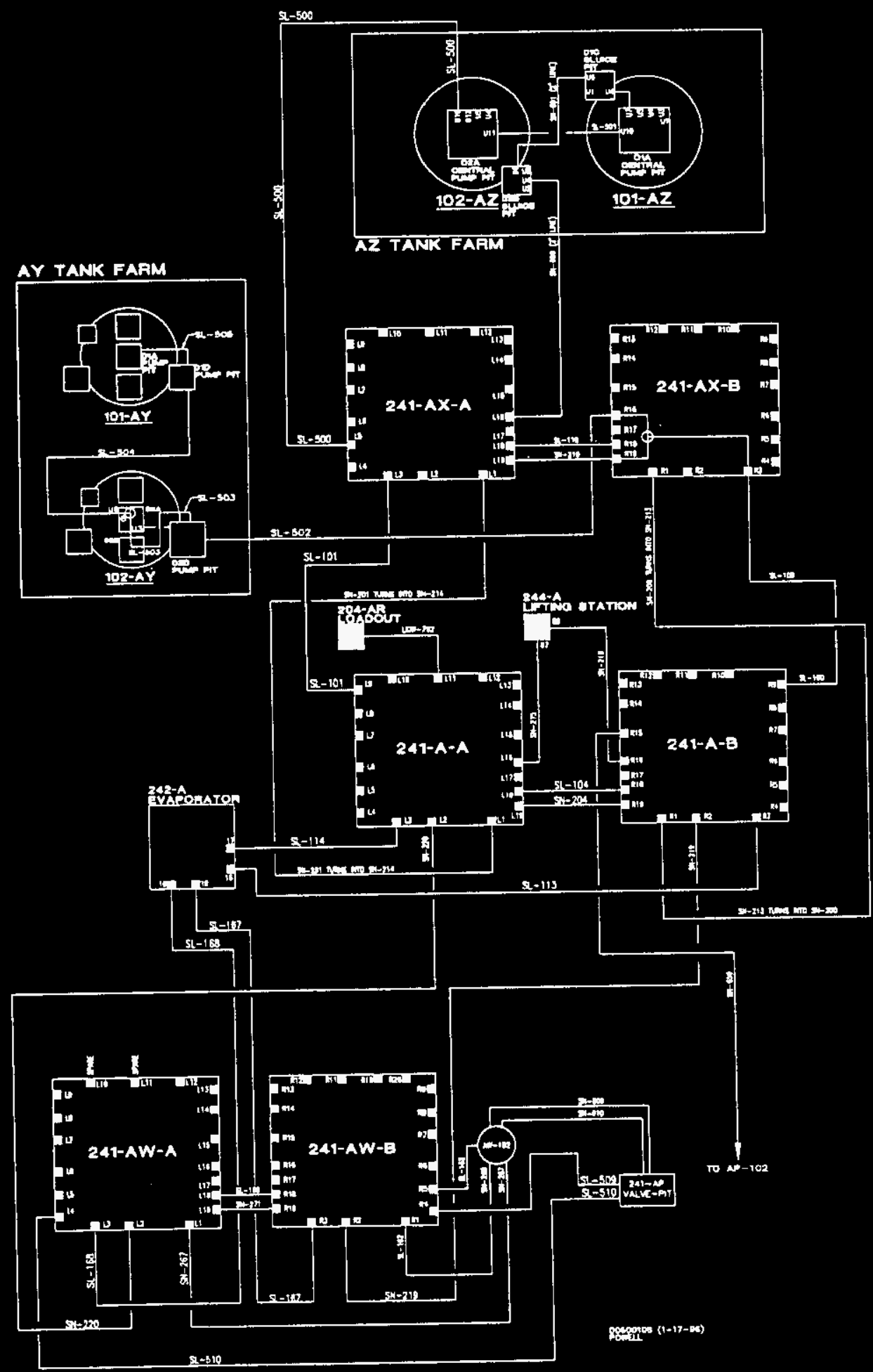


- Portable substation power, control, and monitoring equipment for operation of the two pumps and necessary ancillary equipment

- An electrical substation with the capacity to supply eight mixer pumps and associated equipment

- A mixer pump operation and speed control facility at the AZ Tank Farm.

\section{Project $\mathrm{H}-320$}

Project $W-320$ adds the waste retrieval sluicing system to $C-106$. The solids in C-106 are sluiced to AY-102 and the 1 iquid is recycled.

Project $\mathrm{W}-320$ adds the following to $\mathrm{C}-106$ :

- Two slicers

- A slurry pump

- A heel pump

- A viewing system

- Probes

- A ventilation system

- Jumpers/valve actuators.

Project W-320 adds the following to AY-102:

- Supernatant pump

- Distributor

- Probes

- Valve actuators.

The project also adds the fluid transfer 1 ines between tanks and miscell aneous wiring.

\section{Project $\mathrm{H}-211$}

Project $\mathrm{W}-211$ adds mixing pumps and retrieval systems to ten double-shell tanks in SY, AN, AP, AY, and AZ Tank Farms. The mixing pumps installed in AZ-102 in 2000 will be the first to be used to support aging waste activities. The pumps will facilitate the leaching and washing of solids in AZ-102.

Two other tanks may receive retrieval systems before AZ-102. The retrieval systems are tentatively scheduled for SY-102 in 1998 and AN-105 in 1999. Project $\mathrm{W}-211$ includes the following:

- Sludge mobilization assemblies (mixer pumps)

- An operator station for each tank

- Instrumentation to meet installation and operating needs

- Internal tank upgrades to add structural strength to withstand jet forces

- Transfer pumps 
WHC-SD-WH-ER-532

Revision 0

- Utilities

- Pump pits, riser extensions, and cover blocks as needed

- Flush and dilution capability

- Video monitoring.

\section{0ther projects}

In addition, other projects will affect the consolidation activities. These other projects include Project W-030, Tank Farm Ventilation Upgrade, and Project W-314, the Tank Farm Restoration Upgrades. Each of these projects will have an operational readiness review scheduled as part of the project activities.

\section{Costs and schedules}

Operational readiness reviews for projects are generally conducted in the last 6 to 12 months of the project and completed before the project-provided equipment is turned over to operations. Costs for readiness review will vary somewhat from project to project depending on the complexity of the affected operations and the magnitude of potential hazards. As an example, the cost for the operational readiness review for the installation of a Project W-211 retrieval system in one tank is an estimated $\$ 600,000$. This cost is included as part of the project cost and should be typical for the retrieval systems and mixing systems in each tank.

\section{Assumption for Aging Waste Consolidation}

Readiness reviews are included as an integral part of all projects related to aging waste consolidation. Routine and ongoing tank farm operations comprise the remainder of the activities associated with aging waste consolidation.

An overall readiness review for solids consolidation is recommended if Alternatives $3,5 a, 5 b, 5 c, 6$, or 7 are chosen for implementation. Any of these alternatives results in a larger volume of solids in one tank. The resulting volume of solids may result in additional cooling requirements or other operating and retrieval concerns beyond the other alternatives. The cost of an overall readiness review is an estimated $\$ 500,000$ for a review that requires between 6 and 12 months to complete.

\section{REFERENCES}

Aguirre, Jr., H., 1995, 242-A Evaporator/Crystallizer Final Safety Analysis Report, WHC-SD-WM-SAR-023, Rev. 2, West inghouse Hanford Company, Richl and, Washington. 
WHC-SD-WM-ER-532

Revision 0

DOE, 1993, Startup and Restart of Nuclear Facilities Operational Readiness Review and Readiness Assessments, DOE Order 5480.31, U.S. Department of Energy, Washington, D.C.

WHC-CM-1-5, Standard Operating Practices, Westinghouse Hanford Company, Richland, Washington.

\section{GLOSSARY}

\section{ABBREVIATIOUS AN ACROWYHS}

DOE

U.S. Department of Energy

DQO data quality objective

DSSF double-shell slurry feed

FY fiscal year

IOSR interim operating safety requirement

NCAW neutralized current acid waste

OSD

OSR

ROM operating specification documentation operating safety requirement rough order of magnitude 


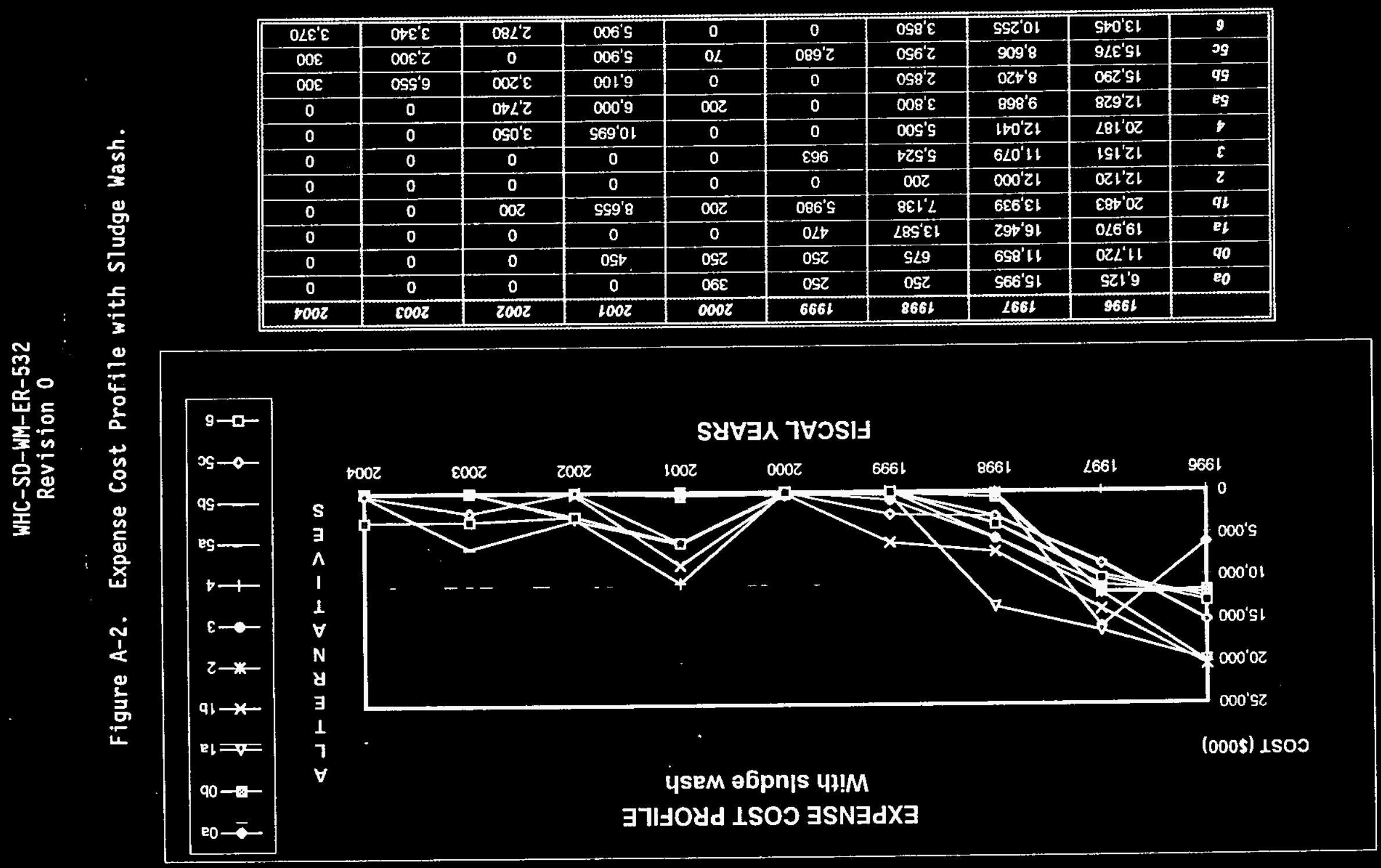


WHC-SD-WM-ER-532

Revision 0

Figure A-3. Expense Cost Profile without Sludge Wash.
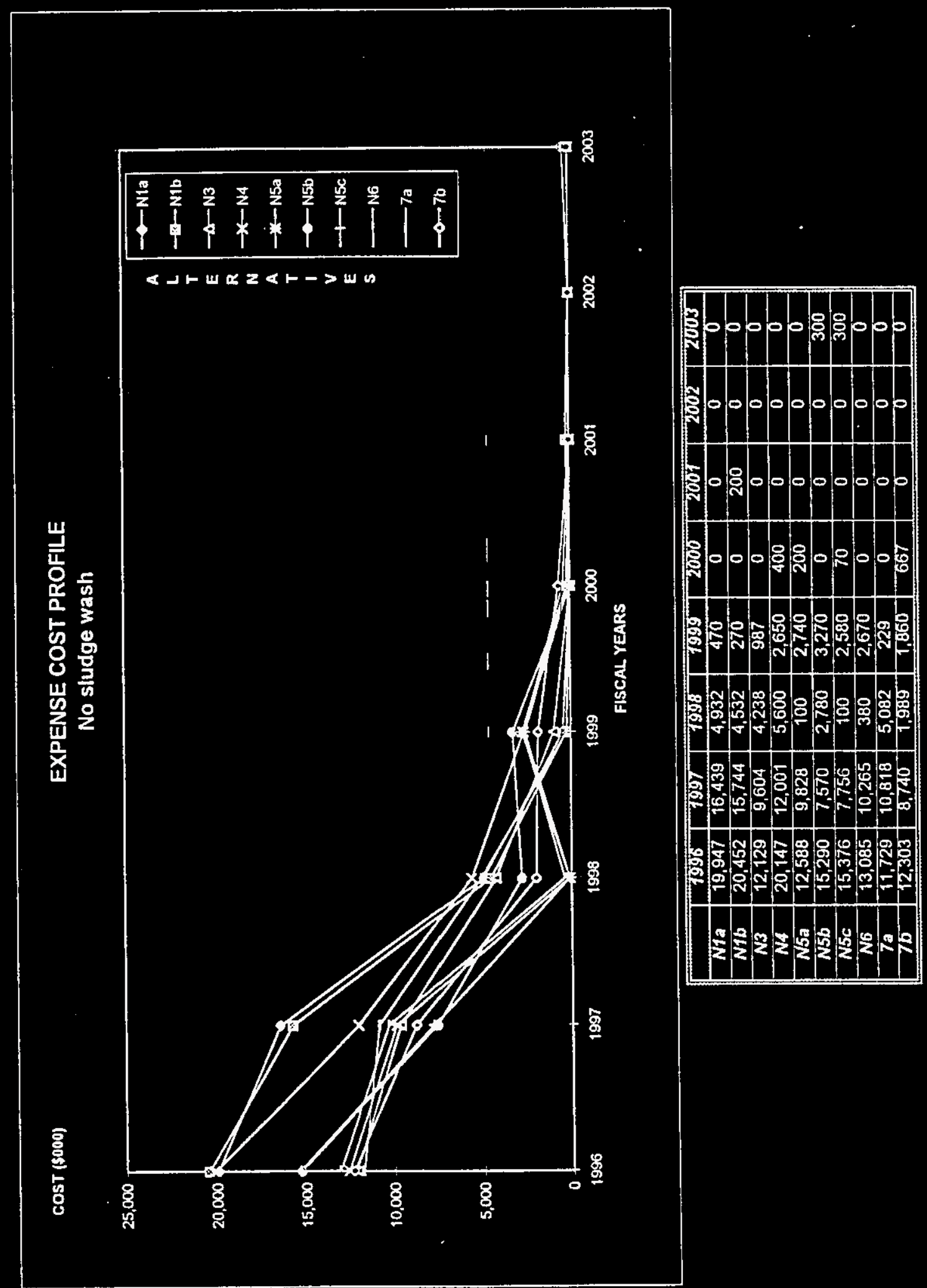
WHC-SD-WM-ER-532

Revision 0

\section{ICF KAISER HANFORD CONPANY ESTIMATES}

ALTERNATIVE Oa

DO NOTHING

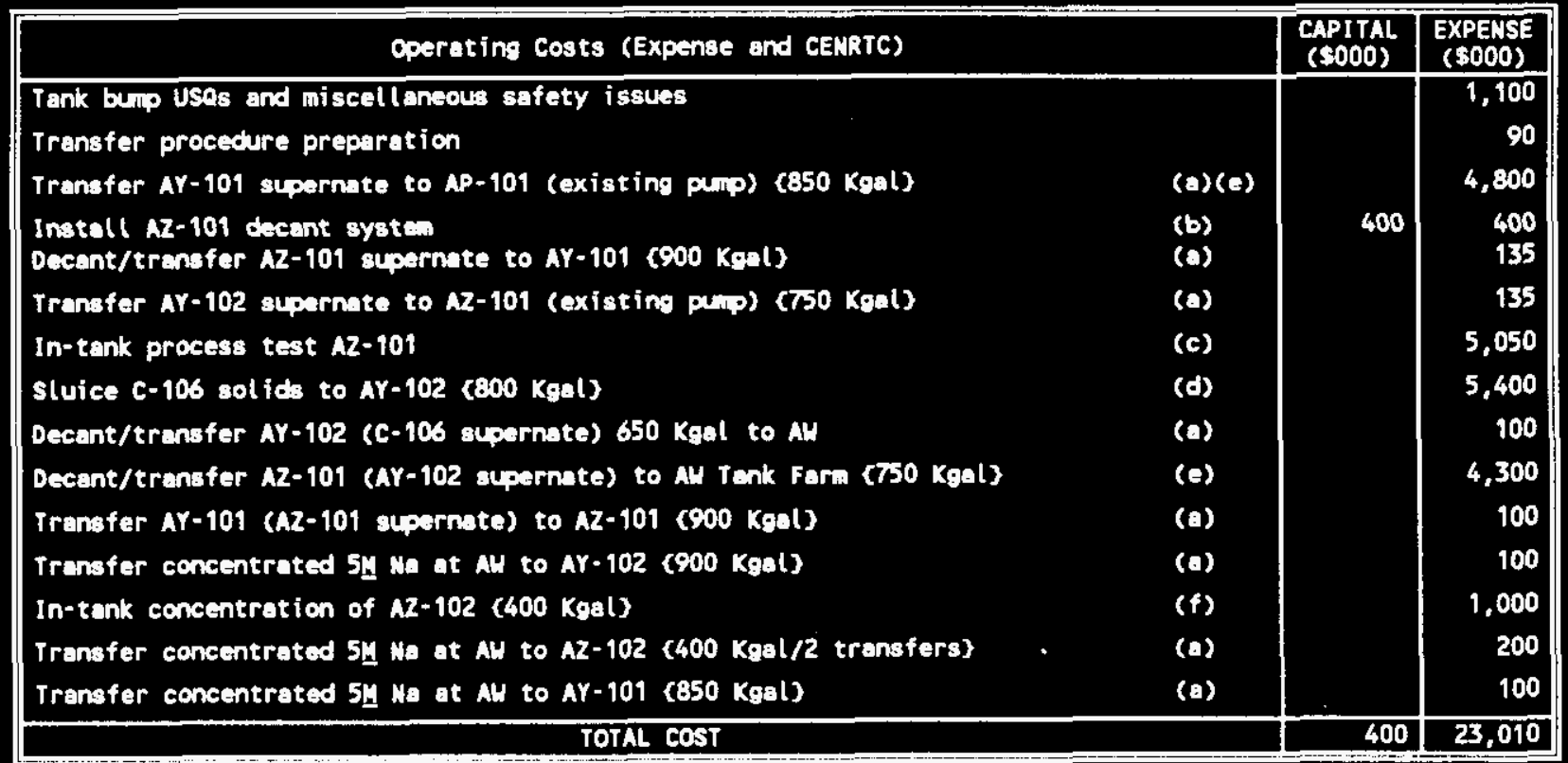

WOTE: See footnotes (a) throwh (h) starting on page $A-48$.

(f) In-tank concentration in eny of the aging waste tanks is assumed to be accomplished with the existing ventilation system $(H-030)$. Accompl ishment of this task will require shutdown of the individual tenk condensers and ruming the ventilation system chiller condenser systen at an increased rate. The chiller condenser system routes the collected condensate to catch tank 241-AZ-151. Purping of the catch tank is a routine 12-Kgal transfer.

In order to pup out catch tank AZ-151 the waste is transferred through line 4605 to diversion box 241-AZ-152. The waste is then routed through line D-602 to the A2-102-02A punp pit, and through SL-500 to the AX-A valve pit. The waste can either be routed to AU or AP Tank Farms to be staged for evaporation at the $242-A$ evaporator or be routed to a dilute waste DST receiver tank such as AY-101. It is assumed this operation would last approximately 5 to 6 years for AZ-102. 
WHC-SD-WM-ER-532

Revision 0

ALTERNATIVE Ob

MINIMAL CASE

\begin{tabular}{|c|c|c|c|}
\hline Operating Costs (Expense and CENRTC) & & $\begin{array}{l}\text { CAPITAL } \\
(\$ 000)\end{array}$ & $\begin{array}{c}\text { EXPENSE } \\
(\$ 000)\end{array}$ \\
\hline 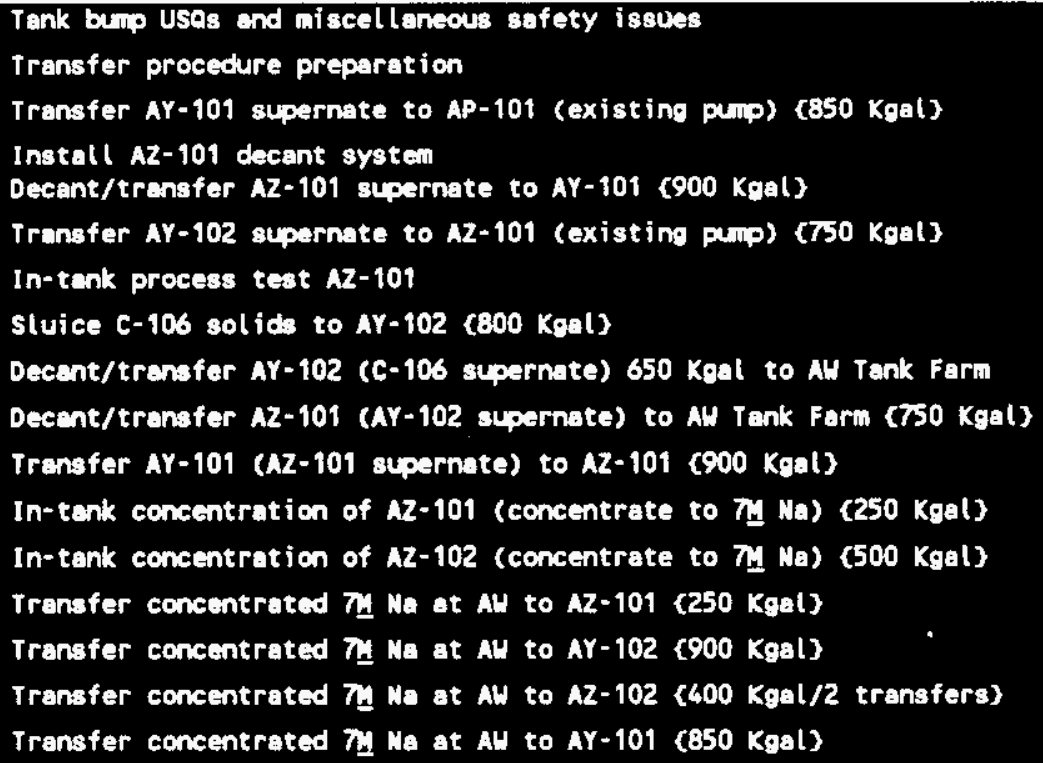 & $\begin{array}{l}\text { (a)(e) } \\
\text { (b) } \\
(a) \\
(a) \\
(d) \\
(a) \\
(a) \\
(a) \\
(f) \\
(f) \\
(a) \\
(a) \\
(a)\end{array}$ & 400 & $\begin{array}{r}2,300 \\
99 \\
4,800 \\
400 \\
135 \\
135 \\
5,050 \\
5,400 \\
100 \\
4,300 \\
100 \\
635 \\
1,250 \\
100 \\
100 \\
200 \\
100\end{array}$ \\
\hline TOTAL COST & & 400 & 25,204 \\
\hline
\end{tabular}

NOTE: See footnotes (o) through (h) starting on page $A-48$.

(f) In-tank concentration in any of the aging waste tanks is assumed to be accomplished with the oxisting ventilation systen (U-030). Accomplishment of this task will require shutdown of the individual tenk condensers and ruming the ventilation systen chiller condenser system at an increased rate. The chiller condenser systed routes the collected condensate to catch tank 241-A2-151. Puping of the catch tank is a routine 12-Kgal transfer.

In order to puip out catch tank $A z-151$ the waste is transferred through line 4605 to diversion box 241-AZ-152. The waste is then routed through line D-602 to the Az-102-02A pump pit, and through SL-500 to the $\boldsymbol{N}$-A valve pit. The waste can either be routed to AH or AP Tank farms to be staged for evaporation at the 242-A evaporator or be routed to a dilute waste DST receiver tank such as AY-101. It is assuned this operation would last approximately 1 to 2 years for AZ-101 and 5 to 6 years for $A Z-102$. 
WHC-SD-WM-ER-532

Revision 0

ALTERNATIVE la

Reroute $\mathrm{W}-320$ pipelines from $\mathrm{C}-106$ to $\mathrm{AZ}-101 ; \mathrm{C}-106$ solids sluiced to $\mathrm{AZ}-101$

\begin{tabular}{|c|c|c|c|}
\hline \multicolumn{2}{|l|}{ Project (Capital) } & $\begin{array}{l}\text { CAPITAL } \\
(\$ 000)\end{array}$ & $\begin{array}{l}\text { EXPENSE } \\
(\$ 000)\end{array}$ \\
\hline \multicolumn{2}{|l|}{ 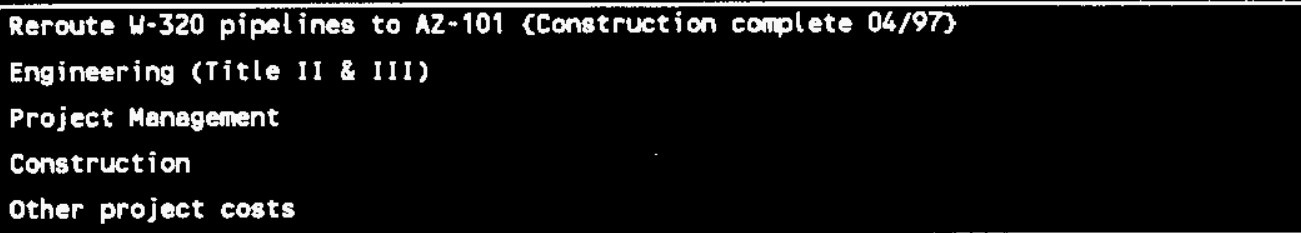 } & & $\begin{array}{r}3,650 \\
940 \\
10,550 \\
1,220\end{array}$ \\
\hline \multicolumn{4}{|l|}{ Operating Costs (Expense and CENRTC) } \\
\hline 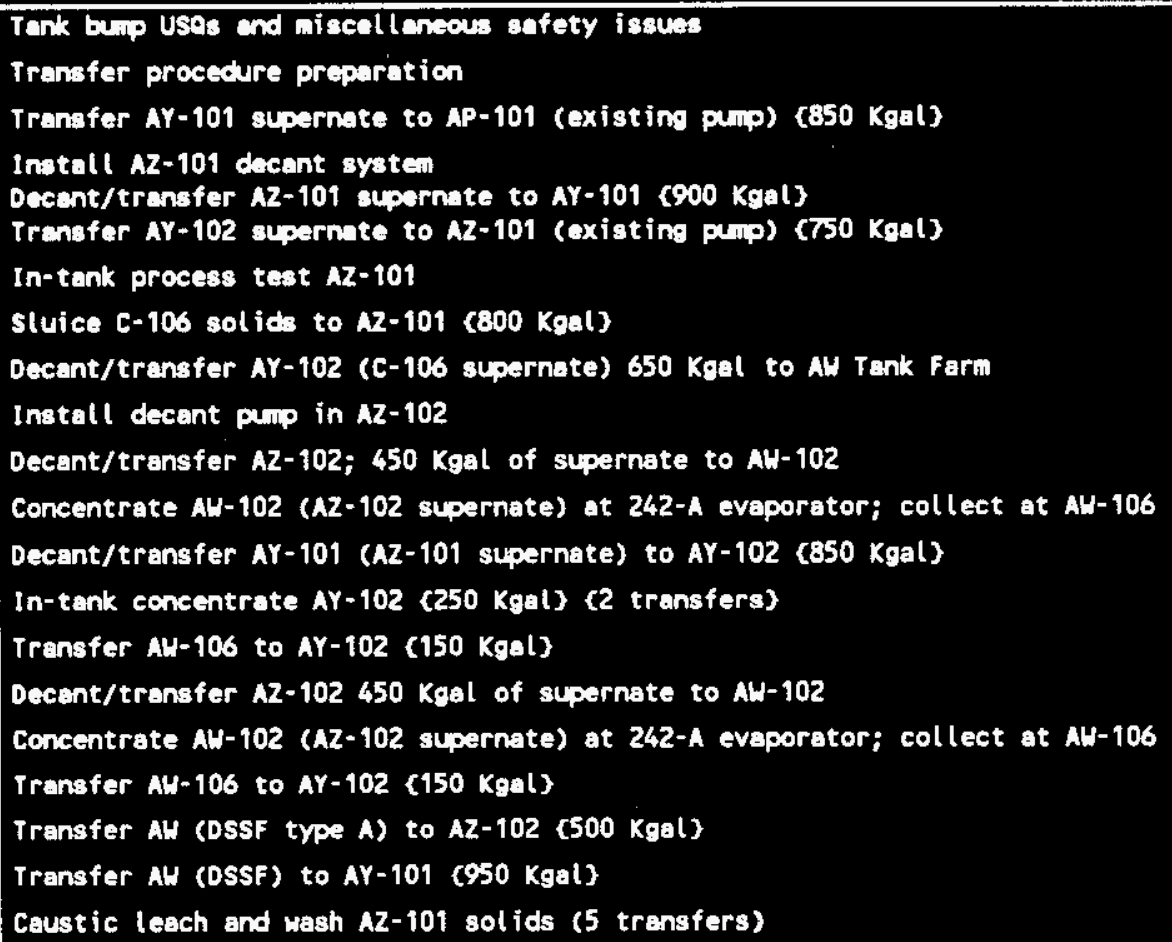 & $\begin{array}{l}\text { (g) } \\
\text { (g) } \\
(e) \\
\text { (g) } \\
\text { (a) } \\
\text { (a) } \\
\text { (h) }\end{array}$ & $\begin{array}{l}400 \\
400\end{array}$ & $\begin{array}{r}2,500 \\
153 \\
4,800 \\
400 \\
135 \\
135 \\
5,050 \\
5,400 \\
100 \\
400 \\
80 \\
2,500 \\
100 \\
800 \\
70 \\
80 \\
2,500 \\
70 \\
100 \\
100 \\
8,655\end{array}$ \\
\hline TOTAL COST & & 800 & 50,488 \\
\hline
\end{tabular}

NOTE: See footnotes (a) through (h) starting on page A-48.

(f) In-tank concentration in any of the aging waste tanks is assuned to be accompl ished with the existing ventilation system (U-030). Accouplishrient of this task will recuire shutdown of the individual tank condenaers and ruming the ventilation system chiller condenser system ot an increased rate. The chiller condenser syatem routes the collected condensate to catch tank 241-A2-151. Puping of the catch tenk is a routine 12-Kgal transfer.

In order to purp out catch tank $A Z-151$ the uaste is trensferred through line 4605 to diversion box 241-AZ-152. The waste is then routed through line D-602 to the $A 2-102-02 \lambda$ pup pit, and through SL-500 to the $\Lambda X-A$ valve pit. The waste cen either be routed to AU or AP Tank famis to be staged for evaporation at the 242-A evaporator or be reuted to a dilute waste DST receiver tank such as AY-101. It is assuned this operation would last epproxinately 1 to 2 years for AZ-101.

(h) For caustic leaching and washing of Az-101, it is assuned that four transfers will be performed: tone transfer of $250 \mathrm{Kogl}$ of caustic from $204-A R$ to $A Z-101$

wone transfer of caustic supernate out of $250 \mathrm{Kgal}$ to AU for evaporation at 242-A at \$5.54/gal

- Two transfers of $800 \mathrm{Kgal}$ dilute liquid to AZ-101

wone transfer of $800 \mathrm{Kgal}$ to AH for evaporation at $242-A$ at $55.54 / 9 \mathrm{al}$. 
WHC-SO-WM-ER-532

Revision 0

ALTERNATIVE N1a

Reroute $W-320$ pipel ines from $C-106$ to $A Z-101$;

C-106 solids sluiced to $A Z-101$

\begin{tabular}{|c|c|c|c|}
\hline \multicolumn{2}{|l|}{ Project (Capital) } & $\begin{array}{l}\text { CAPITAL } \\
(5000)\end{array}$ & $\begin{array}{l}\text { EXPENSE } \\
(\$ 000)\end{array}$ \\
\hline \multicolumn{2}{|l|}{$\begin{array}{l}\text { Reroute W-320 pipelines to } \mathbf{A Z - 1 0 1} \text { (Construction complete } 04 / 97 \text { ) } \\
\text { Engineering (Title II \& III) } \\
\text { Project Management } \\
\text { Construction } \\
\text { Other project costs }\end{array}$} & & $\begin{array}{r}3,650 \\
940 \\
10,550 \\
1,220\end{array}$ \\
\hline \multicolumn{4}{|l|}{ Oparating Costs (Expense and CENRTC) } \\
\hline 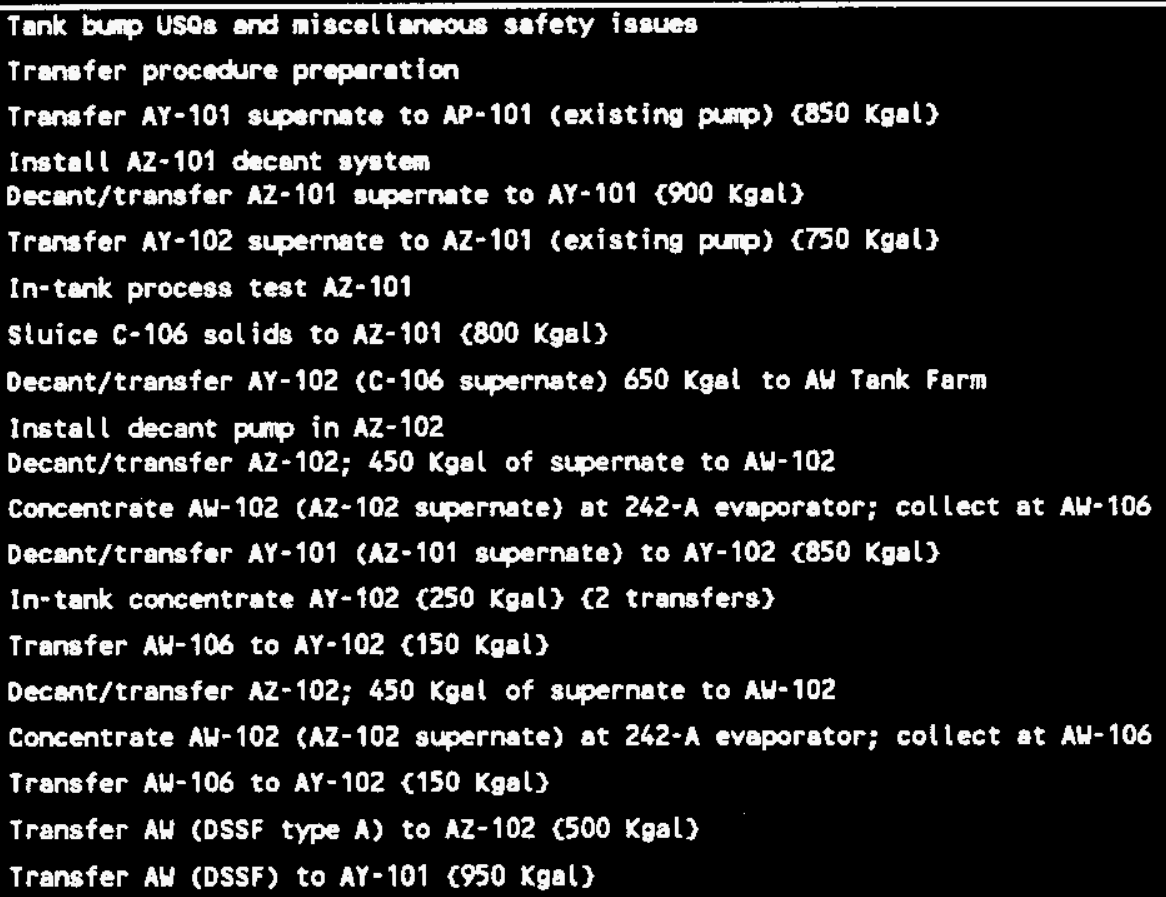 & $\begin{array}{l}(a)(e) \\
(b) \\
(a) \\
(a) \\
(d) \\
(a) \\
(b) \\
(a) \\
(a) \\
(a) \\
(a) \\
(a) \\
(a) \\
(a) \\
(a)\end{array}$ & 400 & $\begin{array}{r}2,500 \\
108 \\
4,800 \\
400 \\
135 \\
135 \\
5,050 \\
5,400 \\
100 \\
400 \\
80 \\
2,500 \\
100 \\
800 \\
70 \\
80 \\
2,500 \\
70 \\
100 \\
100\end{array}$ \\
\hline TOTAL COST & & 800 & 41,788 \\
\hline
\end{tabular}

NOTE: See footnotes (a) throwh (h) starting on page $A-48$.

(f) In-tank concentration in eny of the aging woste tenks is assuned to be accompl ished with the existing ventilation systen (U-030). Acccupl ishwent of this task uill require shutdown of the individul tank condensers and ruming the ventilation system chiller condenser system at an increased rate. The chiller condenser syatem routes the collected condensete to catch tank 241-A2-151. Puming of the catch tank is : routine 12-keal transfer.

In order to $P \mathrm{~B}_{\mathrm{i}}$ out catch tank $\mathrm{AZ}-151$ the wate is trensferred through 1 ine 4605 to diversion box $241-A Z-152$. The unste is then routed through I ine D-602 to the A2-102-02A pup pit, and through SL-500 to the $A X-A$ valve pit. The waste cen either be routed to AH or AP Tank farms to be staged for eveporation at the 242-A evaporator or be routed to a dilute waste DSt receiver tank such as AY-101. It is assuned this operation would last approxinately 1 to 2 years for AZ-101. 


\section{ALTERNATIVE Ib}

Reroute $\mathrm{W}-320$ pipelines from $\mathrm{C}-106$ to $\mathrm{AZ}-101 ; \mathrm{C}-106$ solids sluiced to $A Z-101$. Transfer $A Z-102$ solids to $A Z-101$.

\begin{tabular}{|c|c|c|c|}
\hline \multicolumn{2}{|l|}{ Project (Capital) } & $\begin{array}{l}\text { CAPITAL } \\
(S 000)\end{array}$ & $\begin{array}{l}\text { EXPENSE } \\
(\$ 000)\end{array}$ \\
\hline \multicolumn{2}{|l|}{$\begin{array}{l}\text { Reroute W-320 pipelines to } \mathrm{AZ}-101 \text { (Construction complete 12/97) } \\
\text { Engineering (Title II \& III) } \\
\text { Project Menagenent } \\
\text { Construction } \\
\text { Other project costs } \\
\text { U-211 Initial Waste Retrieval Systen/A2-102 (Construction complete 09/00) } \\
\text { Engineering (Title II \& III) } \\
\text { Project Menagement } \\
\text { Construction } \\
\text { Other project costs }\end{array}$} & $\begin{array}{r}5,160 \\
1,820 \\
16,120 \\
3,020\end{array}$ & $\begin{array}{r}3,650 \\
940 \\
10,550 \\
1,220\end{array}$ \\
\hline \multicolumn{4}{|l|}{ Operating Costs (Expense and CENRTC) } \\
\hline 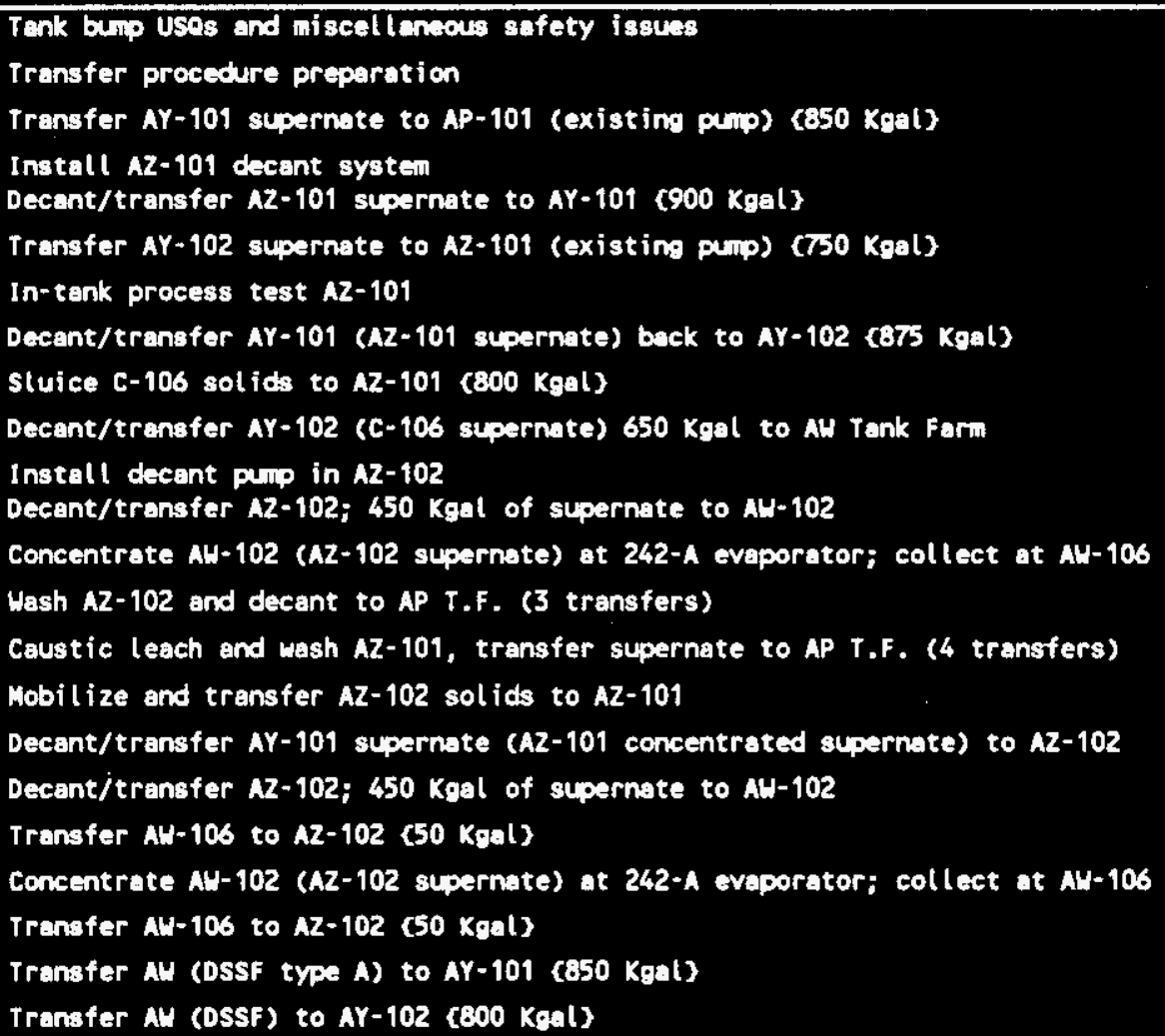 & $\begin{array}{l}\text { (a)(e) } \\
\text { (b) } \\
\text { (a) } \\
\text { (a) } \\
\text { (c) } \\
\text { (a) } \\
\text { (d) } \\
\text { (a) } \\
\text { (b) } \\
\text { (a) } \\
\text { (e) } \\
\text { (h) } \\
\text { (h) } \\
\text { (a) } \\
\text { (a) } \\
\text { (g) } \\
\text { (a) } \\
\text { (a) } \\
\text { (a) } \\
\text { (a) } \\
\text { (a) }\end{array}$ & 400 & $\begin{array}{r}2,500 \\
180 \\
4,800 \\
400 \\
135 \\
135 \\
5,050 \\
100 \\
5,400 \\
100 \\
400 \\
80 \\
2,500 \\
8,655 \\
6,680 \\
100 \\
100 \\
80 \\
70 \\
2,500 \\
70 \\
100 \\
100\end{array}$ \\
\hline TOTAL COST & & 26,920 & 56,595 \\
\hline
\end{tabular}


NOTE: See footnotes (a) through (h) starting on page A-48.

(f) In-tank concentration in any of the aging wate tenks is assumed to be accoupl ished with the existing ventilation system (W-030). Accomplishnent of this task will require shutdown of the individual tank condensers and ruming the ventilation system chiller condenser system at an increased rate. The chiller condenser systew routes the collected condensate to catch tank 241-Az-151. Puiping of the catch tank is a routine 12-Kgal transfer. In order to pup out catch tank A2-151 the waste is transferred through line 4605 to diversion box $241-\wedge 2-152$. The waste is then routed through line D-602 to the AZ-102-02A puip pit, and through SL-500 to the AX-A valve pit. The waste can either be routed to AM or AP Tank Farms to be staged for evaporation at the 242-A eveporator or be routed to a dilute uaste DST receiver tank such as AY-101. It is assuned this operation would last epproximately 1 to 2 years for $A Z-102$.

(h) For caustic leaching and washing of AZ-101, it is assuned that four transfers will be performed. *One transfer of $400 \mathrm{Kogl}$ of caustic from 204-AR to AZ-101

tone transfer of eaustic supernate out of $400 \mathrm{Kgal}$ to AU for evaporation at 242-A evaporator at 55.54/oal

tone trensfer of $500 \mathrm{keal}$ dilute liquid to A2-101

wOne trenafer of $100 \mathrm{Kogl}$ to $\mathrm{AH}$ for evaporation at $242-\mathrm{A}$ evoporator at $35.54 / \mathrm{gal}$. For washing of AZ-102 it is eseuned that 3 trinsfers vill be performed:

"Two trensfors of $300 \mathrm{kgal}$ dilute licuid to $\mathbf{A Z - 1 0 2}$

rone transfer of $300 \mathrm{Keal}$ to AU for evaporation at $242-A$ evaporator at $\$ 5.54 / 9 \mathrm{gl}$. 
WHC-SD-WM-ER-532

Revision 0

ALTERNATIVE N1b

Reroute $\mathrm{W}-320$ pipelines from $\mathrm{C}-106$ to $\mathrm{AZ}-101 ; \mathrm{C}-106$ solids sluiced to $A Z-101$. Transfer $A Z-102$ solids to $A Z-101$.

\begin{tabular}{|c|c|c|c|}
\hline \multicolumn{2}{|l|}{ Project (Capital) } & $\begin{array}{c}\text { CAPITAL } \\
(\$ 000)\end{array}$ & $\begin{array}{l}\text { EXPENSE } \\
(\$ 000)\end{array}$ \\
\hline \multicolumn{2}{|l|}{ 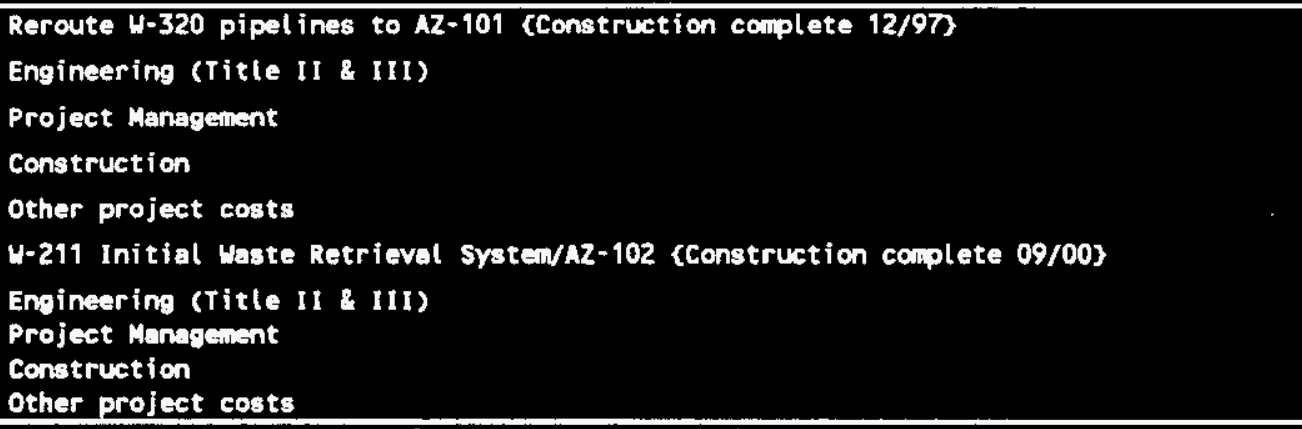 } & $\begin{array}{r}5,160 \\
1,820 \\
16,120 \\
3,020\end{array}$ & $\begin{array}{r}3,650 \\
940 \\
10,550 \\
1,220\end{array}$ \\
\hline \multicolumn{4}{|l|}{ Operating Costs (Expense and CENTRC) } \\
\hline 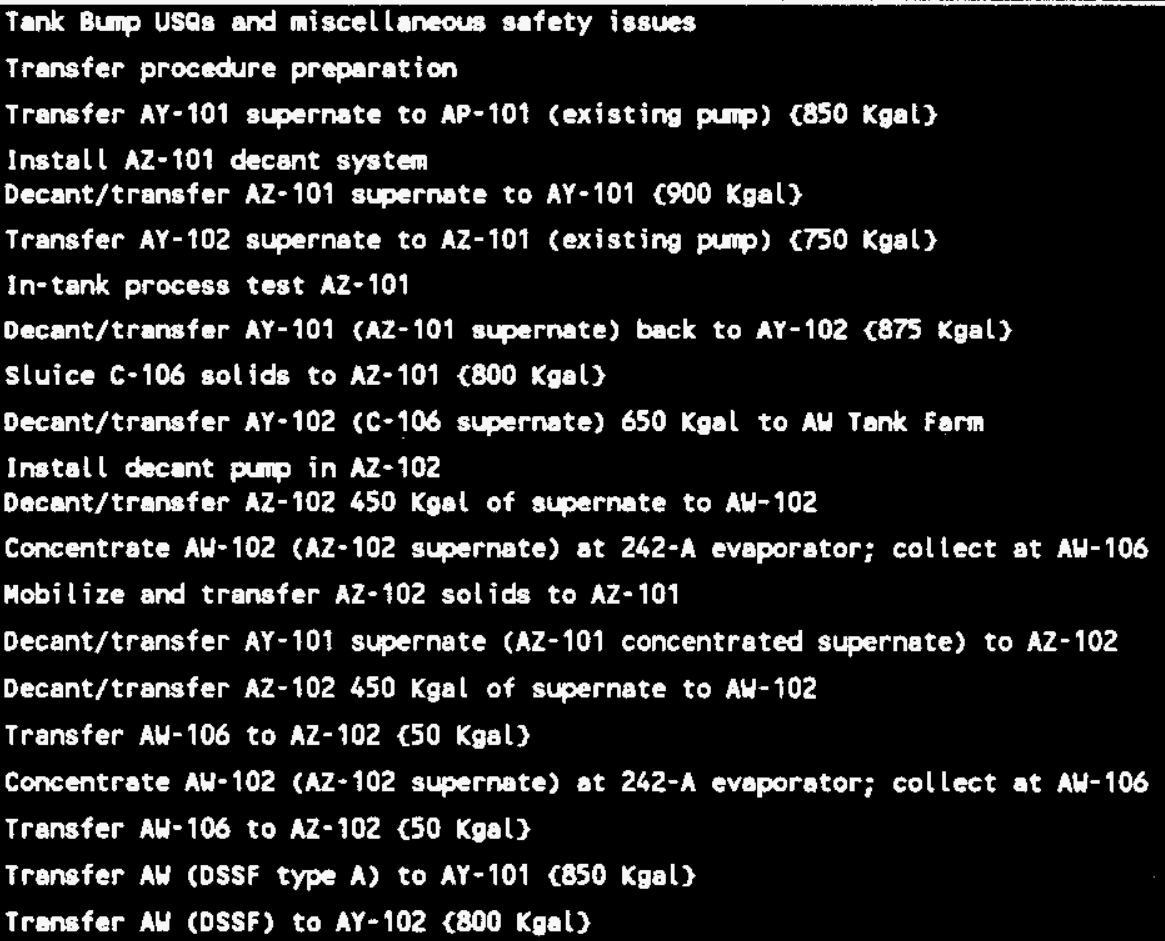 & $\begin{array}{l}\text { (b) } \\
\text { (a) } \\
\text { (a) } \\
\text { (c) } \\
\text { (a) } \\
\text { (d) } \\
\text { (a) } \\
\text { (b) } \\
\text { (a) } \\
\text { (a) } \\
\text { (a) } \\
\text { (a) } \\
\text { (a) } \\
\text { (a) } \\
\text { (a) } \\
\text { (a) } \\
\text { (a) } \\
\text { (a) }\end{array}$ & 400 & $\begin{array}{r}2,500 \\
117 \\
4,800 \\
400 \\
135 \\
135 \\
5,050 \\
100 \\
5,400 \\
100 \\
400 \\
80 \\
2500 \\
100 \\
100 \\
80 \\
70 \\
2500 \\
70 \\
100 \\
100\end{array}$ \\
\hline TOTAL $\cos T$ & & & \\
\hline
\end{tabular}

NOTE: Ses footnotes (a) through (h) starting on page $A-48$.

(f) In-tank concentration in eny of the aging waste tenks is assuned to be accoliplished with the existing ventilation system (U-030). Accompl ishment of this task will recuire shutdom of the individual tank condensers and ruming the ventilation system chiller condenser system at an increased rate. The chiller condenser system routes the collected condensate to catch tank 241-A2-151. Pumping of the catch tank is a routine 12-Kgal transfer.

In order to pump out catch tank AZ-151 the waste is transferred through line 4605 to diversion box 241-AZ-152. The waste is then routed through line 0-602 to the AZ-102-02A pump pit, and through SL-500 to the AX-A valve pit. The waste cen either be routed to AU or AP Tank farms to be staged for evaporation at the 242-A evaporator or be routed to a di lute waste ost receiver tank such as $A Y-101$. It is assumed this operation would last epproximately 1 to 2 years for $A Z-102$. 
WHC-SD-WM-ER-532

Revision 0

ALTERNATIVE 2

Transfer C-106 solids sluiced into AY-102.

\begin{tabular}{|c|c|c|c|}
\hline Operating Costs (Expense and CeNTRC) & & $\begin{array}{l}\text { CAPIIAL } \\
(5000)\end{array}$ & $\begin{array}{c}\text { Expense } \\
(3000)\end{array}$ \\
\hline 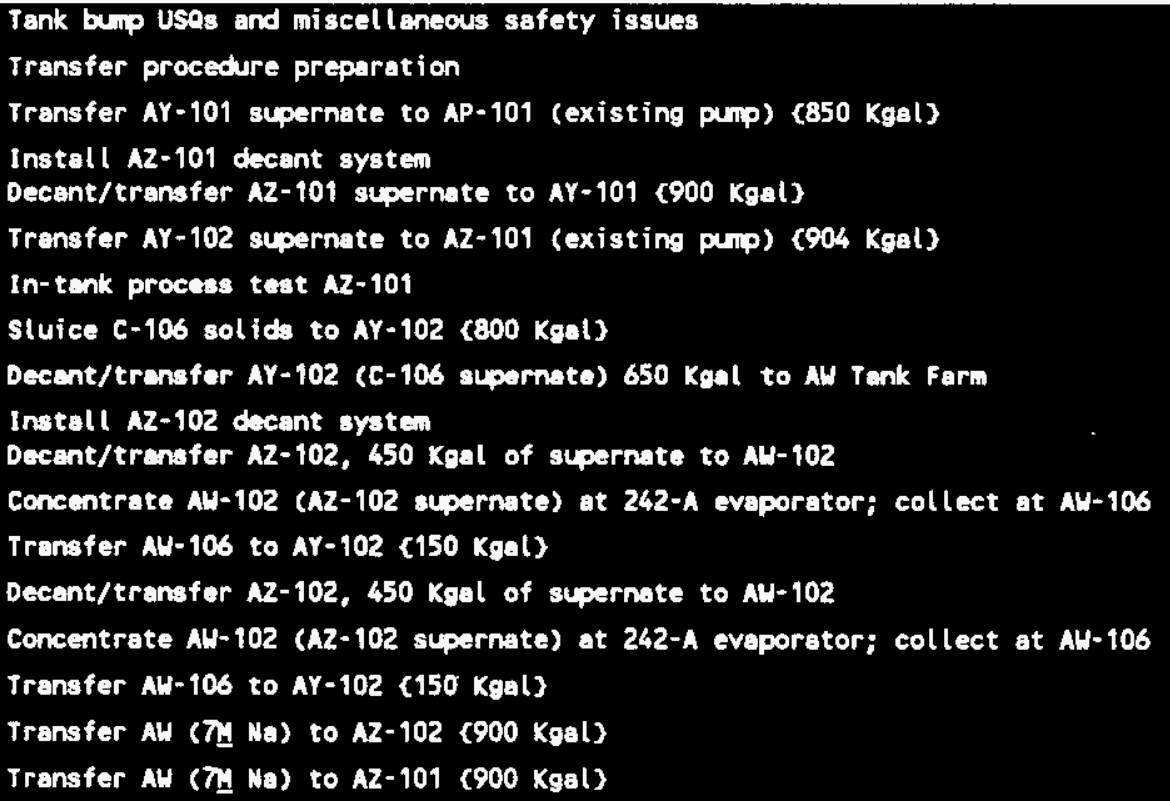 & $\begin{array}{l}\text { (b) } \\
\text { (g) } \\
\text { (e) } \\
\text { (g) } \\
\text { (g) } \\
\text { (e) } \\
\text { (g) }\end{array}$ & 400 & $\begin{array}{r}2,300 \\
99 \\
4,800 \\
400 \\
135 \\
135 \\
5,050 \\
5,400 \\
100 \\
400 \\
80 \\
2,500 \\
70 \\
80 \\
2,500 \\
70 \\
100 \\
100\end{array}$ \\
\hline TOTAL COST & & 800 & 24,319 \\
\hline
\end{tabular}

NOTE: See footnotes (a) through (h) starting on pege $A-48$.

(f) In-tenk concentration in any of the aging waste tanks is assuried to be accomplished with the existing ventilation system $(U-030)$. Accoipl ishnent of this task will require shutdown of the individul tank condensers and ruming the ventilation systea chiller condenser system at an increased rate. The chiller condenser system routes the collected condensate to catch tank 241-A2-151. Puiping of the eatch tank is a routine 12-Kgal transfer.

In order to pump out catch tank AZ-151 the waste is transferred through line 4605 to diversion box 241-AZ-152. The waste is then routed through line D-602 to the $A Z-102-02 A$ pump pit, and through $S L-500$ to the $\boldsymbol{N}-\boldsymbol{A}$ valve pit. The waste can either be routed to AU or AP Tank farms to be staged for evaporation at the 242-A evaporator or be routed to a dilute waste DST receiver tank such as AY-101. It is assuned this operation would last approximately 1 to 2 years for AY-101. 
WHC-SD-WM-ER-532

Revision 0

ALTERNATIVE 3

Transfer C-106 solids sluiced into AY-102 and immediately transfer the solids into tank $A Z-101$.

\begin{tabular}{|c|c|c|c|}
\hline Operating Costs (Expense and CENRTC) & & $\begin{array}{l}\text { CAPITAL } \\
(5000)\end{array}$ & $\begin{array}{l}\text { EXPENSE } \\
(\$ 000)\end{array}$ \\
\hline 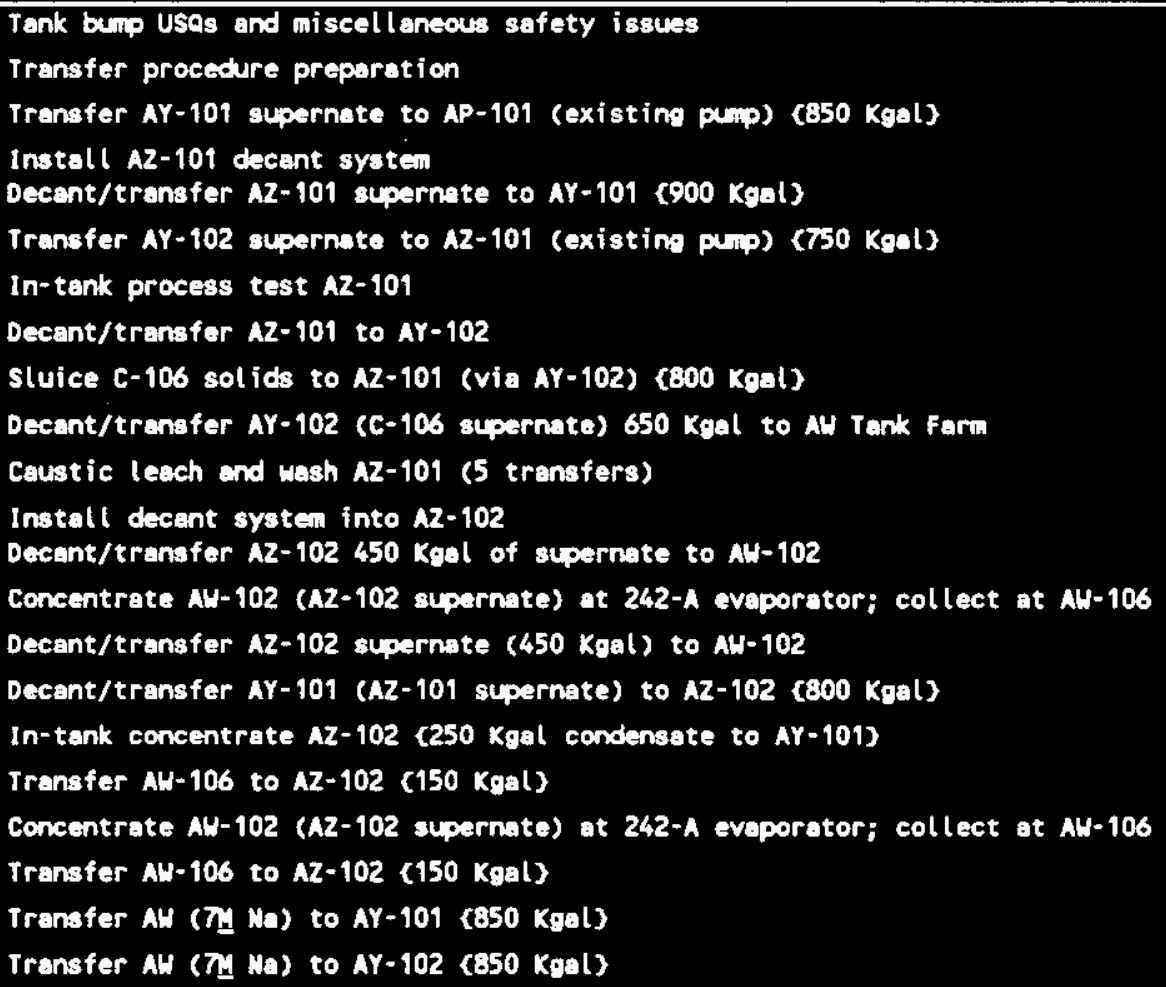 & $\begin{array}{l}\text { (b) } \\
\text { (g) } \\
(e) \\
(g) \\
\text { (a) } \\
(f) \\
\text { (g) } \\
(e) \\
\text { (g) } \\
\text { (a) }\end{array}$ & 400 & $\begin{array}{r}2,300 \\
162 \\
4,800 \\
400 \\
135 \\
135 \\
5,050 \\
135 \\
5,400 \\
100 \\
2,716 \\
400 \\
80 \\
2,500 \\
80 \\
100 \\
2,385 \\
70 \\
2,500 \\
70 \\
100 \\
100\end{array}$ \\
\hline TOTAL COST & & 800 & 29,718 \\
\hline
\end{tabular}

NOTE: See footnotes (a) through (h) starting on page A-48.

(f) In-tank concentration in any of the aging waste tanks is assuned to be accomplished with the existing ventilation system (W-030). Accompl ishment of this task will require shutdown of the individual tank condensers and ruming the ventilation systen chiller condenser systen at an increased rate. The chiller condenser system routes the collected condensate to catch tank 241-AZ-151. Punping of the catch tank is a routine 12-Kgal transfer.

In order to puip out eatch tank AZ-151 the waste is transferred through 1 ine 4605 to diversion box 241-AZ-152. The waste is then routed throwh line $0-602$ to the $A Z-102-02 A$ pump pit, and through SL-500 to the $\boldsymbol{N}$-A valve pit. The waste ean either be routed to AL or AP Tank farms to be staged for evoporation at the 242-A eveporator or be routed to a dilute waste DST receiver tank such as AY-101. It is assuned this operation would last approximately 1 to 2 years for AZ-102.

(h) For caustic leaching and washing of AZ-101, it is assungd that five transfers will be performed. * One transfer of $100 \mathrm{kgal}$ of caustic from 204-AR to AZ-101

- One trensfer of caustic supernate of $100 \mathrm{~K} \cdot \mathrm{al}$ to $\mathrm{AW}$ for eveporation at the 242-A eveporator at $35.54 / \mathrm{eat}$

*To transfers of $300 \mathrm{Koal}$ dilute licuid to $\mathrm{AZ}-101$

*One transfer of $300 \mathrm{kgal}$ to AU for eveporation at the 242-A evaporator at $\$ 5.54 / 9 a l$. 
WHC-SD-WM-ER-532

Revision 0

ALTERNATIVE N3

Transfer C-106 solids sluiced into AY-102 and immediately transfer the solids into tank $A Z-101$.

\begin{tabular}{|c|c|c|c|}
\hline Operating Costs (Expense and CENRTC) & & $\begin{array}{l}\text { CAPITAL } \\
(\$ 000)\end{array}$ & $\begin{array}{l}\text { EXPENSE } \\
(\$ 000)\end{array}$ \\
\hline Tank bump usos and miscellaneous safety issues & & & 2,300 \\
\hline Transfer procedure preparation & & & 117 \\
\hline Transfer AY-101 supernate to AP-101 (existing Pulp) (850 Kgal) & (a)(e) & & 4,800 \\
\hline $\begin{array}{l}\text { Install } A Z-101 \text { decant system } \\
\text { Decant/transfer } A Z-101 \text { s4pernate to } A Y-101(900 \text { Kgal) }\end{array}$ & (b) & 400 & $\begin{array}{l}400 \\
135\end{array}$ \\
\hline Transfer AY-102 supernate to AZ-101 (existing pup) (750 Kgal) & (a) & & 135 \\
\hline In-tank process test $A 2-101$ & (c) & & 5,050 \\
\hline Decant/transfor $A Z-101$ to $A Y-102$ & (a) & & 135 \\
\hline stuice C-106 solids to AZ-101 (vio AY-102) (800 Kgal) & (d) & & 5,400 \\
\hline Decant/transfer AY-102 (C-106 supernate) $650 \mathrm{Kgal}$ to AH Tank Farm & (a) & & 100 \\
\hline $\begin{array}{l}\text { Install decent system into } A Z-102 \\
\text { Decant/transfer } A Z-102 \quad 450 \mathrm{Kgal} \text { of supernate to } A H-102\end{array}$ & (b) & 400 & $\begin{array}{r}400 \\
80\end{array}$ \\
\hline Concentrate AU-102 (AZ-102 aupernate) at 242-A eveporator; collect at AH-106 & (e) & & 2,500 \\
\hline Decant/transfer A2-102 supernate (450 Kgal) to AU-102 & (q) & & 80 \\
\hline Decant/transfer AY-101 (AZ-101 supernate) to AZ-102 (800 Kgal) & (e) & & 100 \\
\hline In-tank concentrate $A Z-102$ (250 Kgal condensate to AY-101) & (f) & & 2,385 \\
\hline Transfer AH-106 to AZ-102 (150 Kgal $)$ & (g) & & 70 \\
\hline Concentrate AH-102 (AZ-102 supernate) at 242-A evaporator; collect at AH-106 & (e) & & 2,500 \\
\hline Transfer $A H-106$ to $A Z-102$ (150 Kgal) & (s) & & 70 \\
\hline Transfer AU (7M No) to AY-101 (850 Kool) & (8) & & 100 \\
\hline Transfer AW (TM Na) to AY-102 (850 Koal) & (8) & & 100 \\
\hline TOTAL COST & & 800 & 26,957 \\
\hline
\end{tabular}

NOTE: See footnotes (a) throuch (h) starting on pace A-48.

(f) In-tank concentration in any of the aging waste tonks is assumed to be accomplished with the existing ventilation system $(W-030)$. Accompl ishment of this task will require shutdown of the individual tank condensers and ruming the ventilation system chiller condenser system at an increased rate. The chiller condenser systcin routes the collected condensate to catch tank 241-A2-151. Pusping of the catch tank is a routine 12-Kgal transfer.

In order to pup out catch tank $\mathrm{AZ}-151$ the waste is trensferred through 1 ine 4605 to diversion box 241-A2-152. The waste is then routed throuch line D-602 to the AZ-102-02A pulp pit, and through SL-500 to the $A X-A$ valve pit. The waste cen either be routed to AH or AP Tank Farms to be staged for eveporation at the 242-A evaporator or be routed to a dilute waste DST receiver tank such as AY-101. It is assund this operation would last approxinately 1 to 2 years for $A Z-102$. 
WHC-SD-WM-ER-532

Revision 0

ALTERNATIVE 4

Reroute $\mathrm{W}-320$ pipelines from $\mathrm{C}-106$ to $\mathrm{AZ}-102$.

Transfer $A Z-101$ solids to $A Z-102$.

\begin{tabular}{|c|c|c|c|}
\hline \multicolumn{2}{|l|}{ Project (Capital) } & $\begin{array}{l}\text { CAPITAL } \\
(\$ 000)\end{array}$ & $\begin{array}{l}\text { EXPENSE } \\
(\$ 000)\end{array}$ \\
\hline 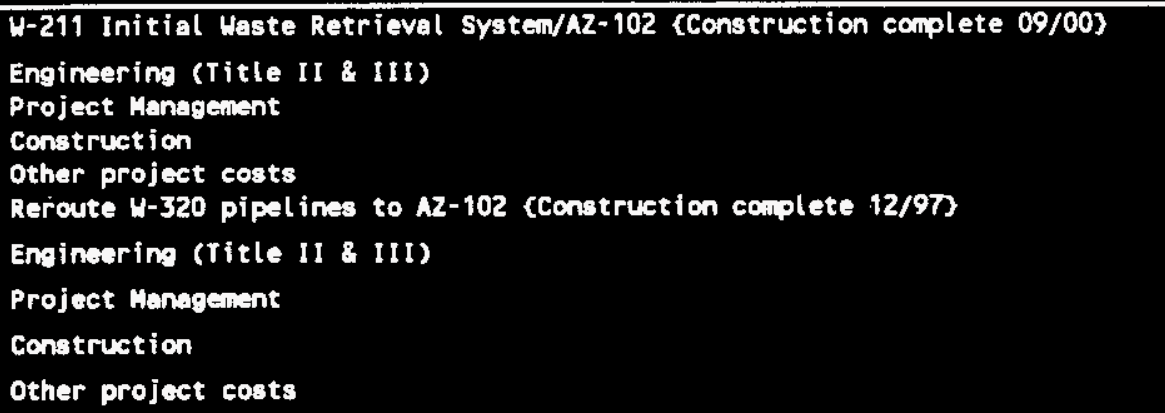 & & $\begin{array}{r}5,160 \\
1,820 \\
16,120 \\
3,020\end{array}$ & $\begin{array}{r}3,650 \\
940 \\
9,940 \\
1,220\end{array}$ \\
\hline Operating Costs (Expense and CEMRTC) & & & \\
\hline 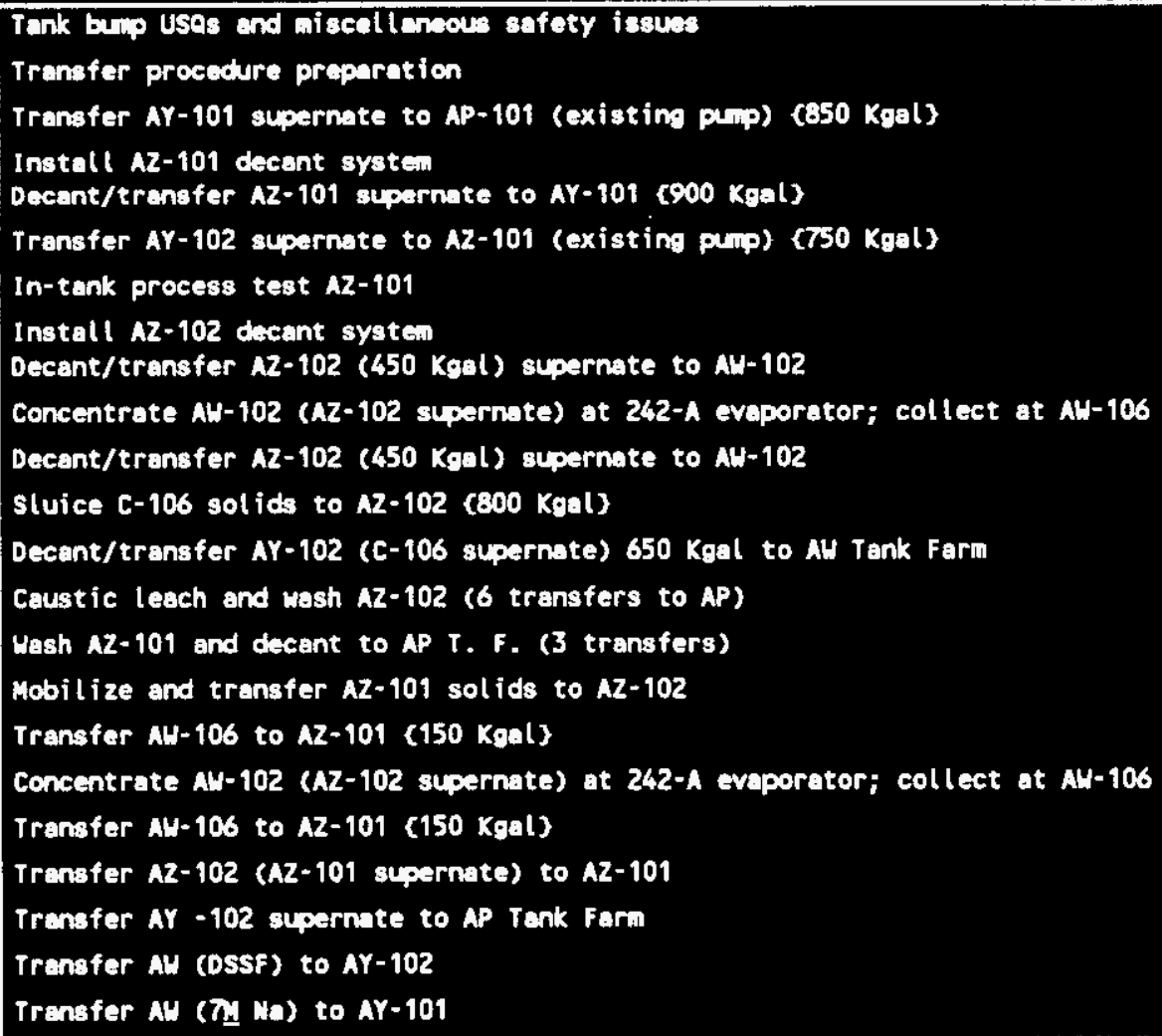 & $\begin{array}{l}\text { (a)(e) } \\
\text { (b) } \\
\text { (a) } \\
\text { (a) } \\
\text { (c) } \\
\text { (b) } \\
\text { (g) } \\
\text { (e) } \\
\text { (a) } \\
\text { (d) } \\
\text { (a) } \\
\text { (h) } \\
\text { (h) } \\
\text { (a) } \\
\text { (g) } \\
\text { (e) } \\
\text { (g) } \\
\text { (a) }\end{array}$ & 400 & $\begin{array}{r}2,700 \\
198 \\
4,800 \\
400 \\
135 \\
135 \\
5,050 \\
400 \\
80 \\
2,500 \\
80 \\
5,400 \\
100 \\
9,187 \\
1,408 \\
100 \\
80 \\
2,500 \\
70 \\
100 \\
100 \\
100 \\
100\end{array}$ \\
\hline TOTAL COST & & $26, \% 20$ & 51,473 \\
\hline
\end{tabular}


NOTE: See footnotes (a) through (h) starting on page $A-48$.

(f) In-tank concentration in ony of the aing uste tenks is agsumad to be accoupl ished with the existing ventilation system (u-030). Accowpl ishwent of this tesk will require shutdown of the individual tank condensers and ruming the ventilation system chiller condenser system at an increased rate. The chiller condenser system routes the collected condensate to catch tank 241-A2-151. Puping of the catch tank is a routine 12-Kgal transfer.

In order to pulip out catch tank $A Z-151$ the waste is transferred through line 4605 to diversion box 241-AZ-152. The waste is then routed through I ine D-602 to the AZ-102-02A plmp pit, and through SL-500 to the $\boldsymbol{N X - \Lambda}$ valve pit. The waste cen either be routed to $A H$ or AP Tank Farms to be staged for eveporation at the 242-A eveporator or be routed to a dilute waste DST receiver tank such as AY-101. It is assund this operation would lest epproxinately 1 to 2 years for AZ-101.

(h) For washing of AZ-101, it is assunied that three transfers will be performad:

- Two transers of $200 \mathrm{Koal}$ dilute liquid to $\mathrm{AZ-101}$

- One transfer of $200 \mathrm{Koal}$ to AU for evaporation ot the 242-A evaporator at $55.54 / 9 a \mathrm{al}$.

for caustic leaching and wahing of AZ-102, it is assund that six transfers will be performed:

- One transfor of $500 \mathrm{keal}$ of waste

- One transfer of $250 \mathrm{kgal}$ of caustic from 204-AR to $M Z-101$

- one trenter of esurtic supernate of $250 \mathrm{keal}$ to AU for evaporation at the 242-A evaporator at 55.56/eal

- Two trensfors of $800 \mathrm{Kad}$ dilute liquid to Az-102

- One transfer of $800 \mathrm{kgal}$ to $\mathrm{AU}$ for evoporation at the $242-\mathrm{A}$ evaporator at $55.54 / \mathrm{gal}$. 
WHC-SD-WM-ER-532

Revision 0

\section{ALTERWATIVE N4}

Reroute $\mathrm{W}-320$ pipelines from $\mathrm{C}-106$ to $\mathrm{AZ}-102$.

Transfer $A Z-101$ solids to $A Z-102$.

\begin{tabular}{|c|c|c|c|}
\hline \multicolumn{2}{|l|}{ Project (Capital) } & $\begin{array}{l}\text { CAPITAL } \\
(\$ 000)\end{array}$ & $\begin{array}{l}\text { EXPENSE } \\
(5000)\end{array}$ \\
\hline \multicolumn{2}{|l|}{$\begin{array}{l}\text { Construction } \\
\text { Other project costs } \\
\text { Reroute U-320 Pipelines to } \mathbf{A - 1 0 2} \\
\text { Engineerim (Title II \& III) } \\
\text { Project Management } \\
\text { Construction } \\
\text { Other project coets }\end{array}$} & $\begin{array}{r}5,160 \\
1,820 \\
16,120 \\
3,020\end{array}$ & $\begin{array}{r}3,650 \\
940 \\
9,940 \\
1,220\end{array}$ \\
\hline \multicolumn{4}{|l|}{ Operating Costs (Expense and CEMRTC) } \\
\hline 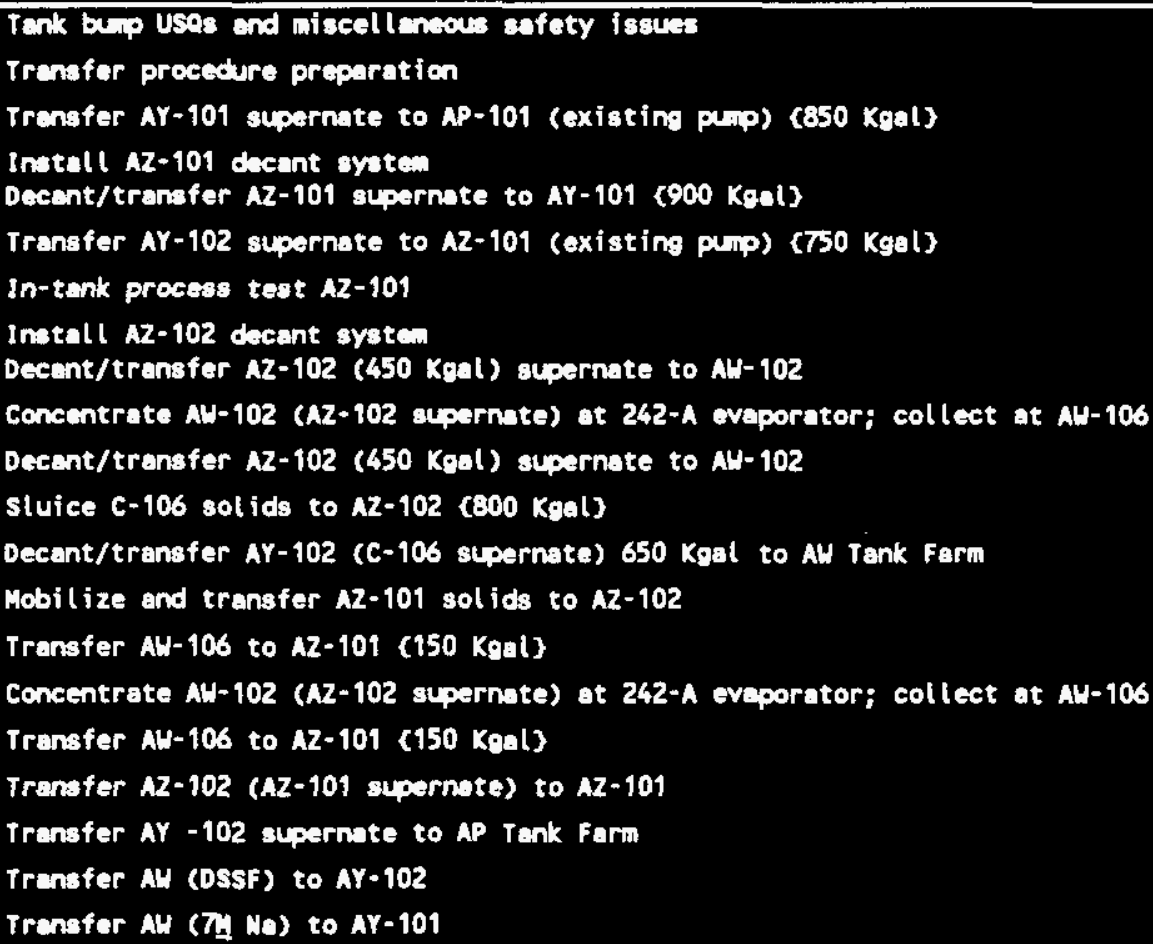 & $\begin{array}{l}\text { (a)(e) } \\
\text { (b) } \\
\text { (a) } \\
\text { (a) } \\
\text { (c) } \\
\text { (b) } \\
\text { (a) } \\
\text { (a) } \\
\text { (a) } \\
\text { (d) } \\
\text { (a) } \\
\text { (a) } \\
\text { (a) } \\
\text { (e) }\end{array}$ & 400 & $\begin{array}{r}2,700 \\
117 \\
4,800 \\
400 \\
135 \\
135 \\
5,050 \\
400 \\
80 \\
2,500 \\
80 \\
5,400 \\
100 \\
100 \\
80 \\
2,500 \\
70 \\
100 \\
100 \\
100 \\
100\end{array}$ \\
\hline TOTAL COST & & 26,920 & \\
\hline
\end{tabular}

NOTE: See foothotes (a) throwh (h) starting on pace $A-48$.

(f) In-tank concentration in any of the aging mate tanks is assumed to be accoinglished with the existing ventilation system $(U-030)$. Accolpl ishomt of this task uill recuire shutdown of the individul tenk condensers and ruming the ventilation system chiller condenser system at an increased rate. The chiller condenser aystem routes the collected condensate to catch tank 241-A2-151. Puping of the catch tenk is a routine 12-kgal transfer.

In order to punp out catch tank A2-151 the waste is transferred through line 4605 to diversion box 241-Az-152. The waste is then routed throwgh tine D-602 to the $A z-102-02 \lambda$ pump pit, and through $S L-500$ to the $A X-A$ valve pit. The waste can either be routed to $A M$ or AP Tank Farms to be staged for evaporation at the 242-A evaporator or be routed to a dilute waste DST receiver tank such as AY-101. It is assuned this operation would last opproximately 1 to 2 years for AZ-101. 
WHC-SD-WM-ER-532

Revision 0

ALTERNATIVE 5a

Consolidation of $A Z$ Tank Farm solids in tank $A Z-102$.

\begin{tabular}{|c|c|c|c|}
\hline \multicolumn{2}{|l|}{ Project (Capital) } & $\begin{array}{l}\text { CAPITAL } \\
(\$ 000)\end{array}$ & $\begin{array}{l}\text { EXPENSE } \\
\text { (\$0O0) }\end{array}$ \\
\hline \multicolumn{2}{|l|}{$\begin{array}{l}\text { W-211 Initial Weste Retrieval Syaten/Az-102 (Construction couplete 09/00) } \\
\text { Engineering (Title } 11 \& 111 \text { ) } \\
\text { Project Managenent } \\
\text { Construction } \\
\text { Other project costs }\end{array}$} & $\begin{array}{r}5,160 \\
1,820 \\
16,120 \\
3,020\end{array}$ & \\
\hline \multicolumn{4}{|l|}{ Operating Costs (Expense and CENRTC) } \\
\hline 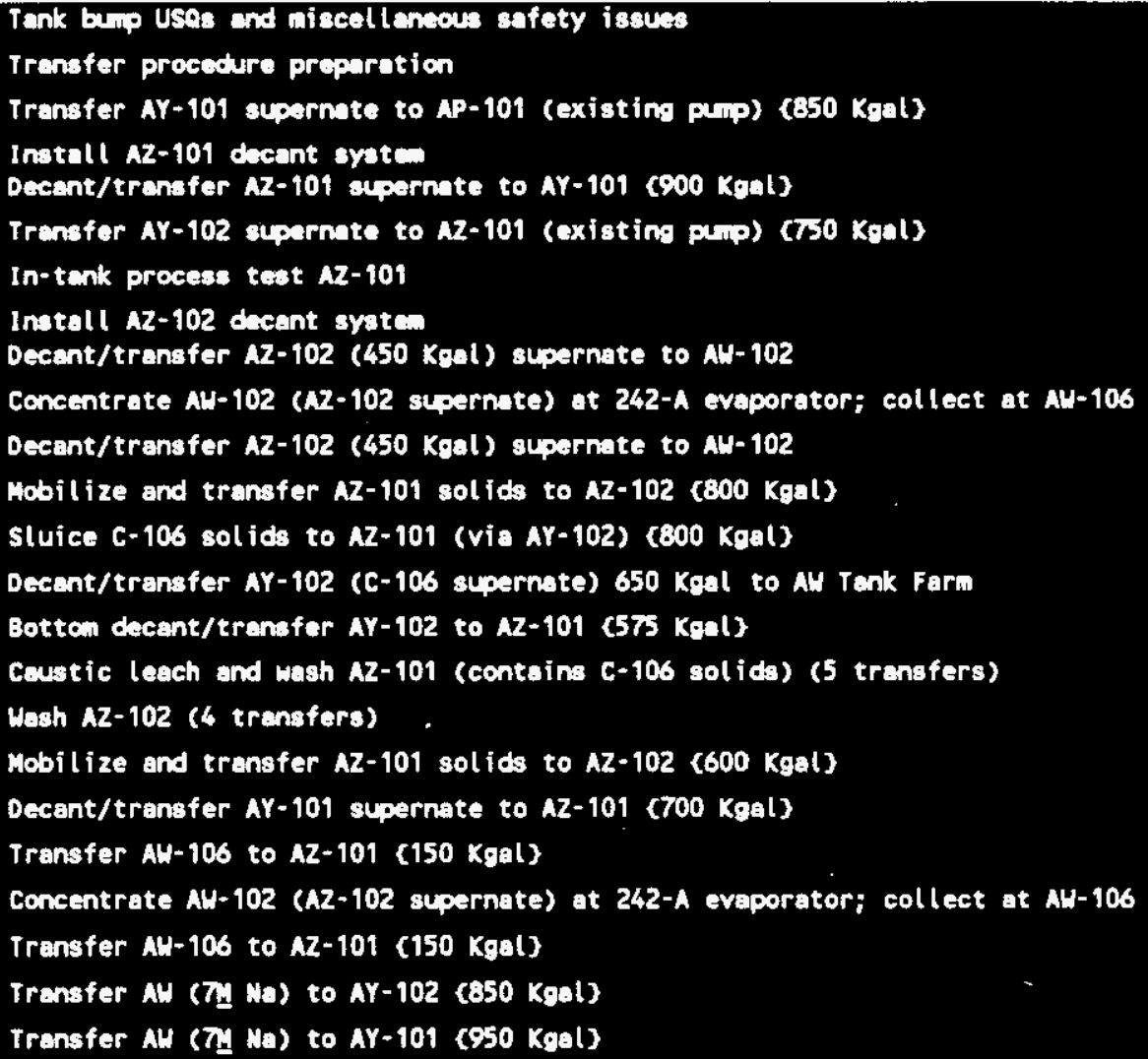 & $\begin{array}{l}\text { (e) } \\
\text { (a) } \\
\text { (a) } \\
\text { (d) } \\
\text { (a) } \\
\text { (a) } \\
\text { (h) } \\
\text { (h) }\end{array}$ & 400 & $\begin{array}{r}3,000 \\
216 \\
4,800 \\
400 \\
135 \\
135 \\
5,050 \\
400 \\
80 \\
2,500 \\
80 \\
100 \\
5,400 \\
100 \\
100 \\
3,800 \\
5,900 \\
100 \\
100 \\
70 \\
2,500 \\
70 \\
100\end{array}$ \\
\hline TOTAL COST & & 26,920 & \\
\hline
\end{tabular}


WHC-SD-WM-ER-532

Revision 0

WOTE: See footnotes (a) throuth (h) storting on page A-48.

(f) In-tank concentration in om of the aging waste tanks is assuined to be seconplished with the existing ventilation system (H-030). Accomplishment of this task will require shutdown of the individual tank condensers and ruming the ventilation systen chiller condenser systen at an increased rate. The chiller condenser systen routes the collected condensate to catch tank 241-AZ-151. Pulping of the catch tank is a routine 12-Kgal transfer.

In order to pup out catch tenk AZ-151 the waste is transferred through line 4605 to diversion box 241-AZ-152. The waste is then routed through line D-602 to the AZ-102-02A puip pit, and through SL-500 to the $\boldsymbol{N X}-\mathbf{A}$ valve pit. The waste cen either be routed to AU or AP Tank Farms to be staged for eveporation at the 242-A eveporator or be routed to a dilute waste DST receiver tank such as AY-101. It is essunis this eperation would last epproximately 1 to 2 years for AZ-101.

(h) For ceustic leaching and whing of A2-101, it is assund that five transfers will be performed: *ons tremsfor of $100 \mathrm{Keal}$ of esuetic fram 204-AR to $A Z-101$

tone trenfer of $100 \mathrm{kal}$ of ceutic supernate to AW for eveporation ot the 242-A evaporator at $55.54 / \mathrm{sal}$

tTwo tremefers of $500 \mathrm{Kenl}$ dilute liquid to $\mathrm{AZ}-101$

tone trensfer of $500 \mathrm{Keal}$ to $M$ for eveporation at the $242-\mathrm{A}$ evaporator at $55.54 / \mathrm{gal}$.

For washing of A2-102, it is eseund that four transfers will be performed:

* Two trenefors of $500 \mathrm{Keal}$ dilute liquid to $\mathrm{Az}-102$

"Two trensfers of $500 \mathrm{Kaal}$ to AH for eveporation ot the 242-A evaporator at $\$ 5.54 / \mathrm{gal}$. 
ALTERNATIVE N5a

Consolidation of $A Z$ Tank Farm solids in tank $A Z-102$.

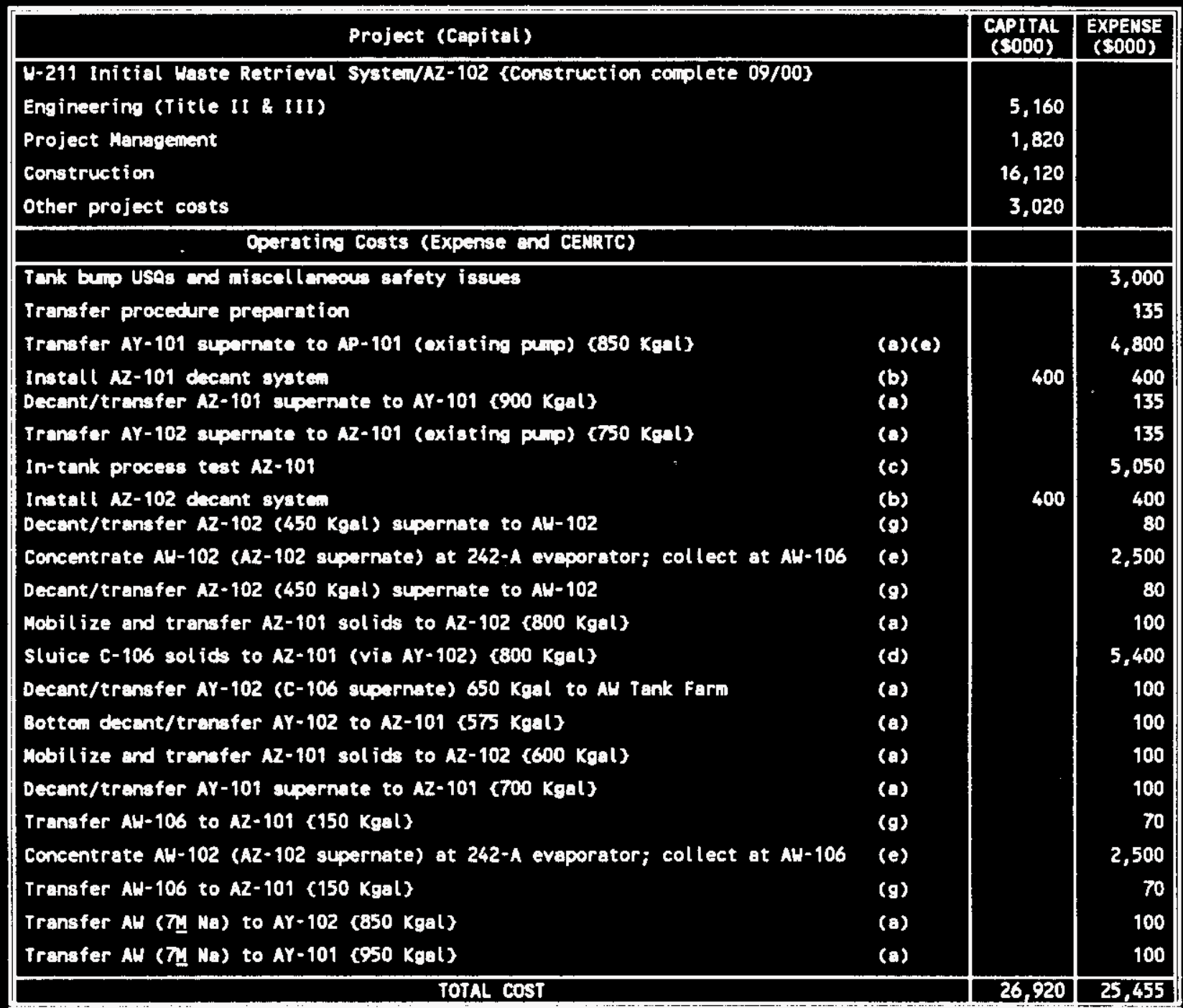

NOTE: See footnotes (a) throwis (h) starting on pase A-48.

(f) In-tank concentration in sny of the oging waste tenks is assunad to be accoliplished with the existing ventiletion syatem (U-030). Acecoplishant of this task will recuire shutdown of the individual tenk condensers and ruming the ventilation system chiller condenser syatem ot an increased rate. The chiller condenser syatcm routes the collected eondinsate to catch tank 241-AZ-151. Puming of the eatch tenk is a routin 12-k-al transfor.

In order to pup out catch tenk $A Z-151$ the mate is transferred through 1 ine 4605 to diversion box 241-AZ-152. The waste is then routed throuth line D-602 to the A2-102-02A P pip pit, and through SL-500 to the $\boldsymbol{N X}$-A valve pit. The waste cen either be routed to AU or AP rank farmis to be staged for eveporation at the 242-A eveporator or be routed to a dilute waste DST receiver tank such as AY-101. It is assuned this operation would lest epproximately 1 to 2 years for AZ-101. 
WHC-SD-HM-ER-532

Revision 0

ALTERNATIVE 5b

Consolidation of $A Y-102$ and $A Z$ Tank Farm solids in tank $A Z-102$.

\begin{tabular}{|c|c|c|c|}
\hline \multicolumn{2}{|l|}{ Project (Capital) } & $\begin{array}{l}\text { CAPITAL } \\
(5000)\end{array}$ & $\begin{array}{c}\text { EXPENSE } \\
(\$ 000)\end{array}$ \\
\hline 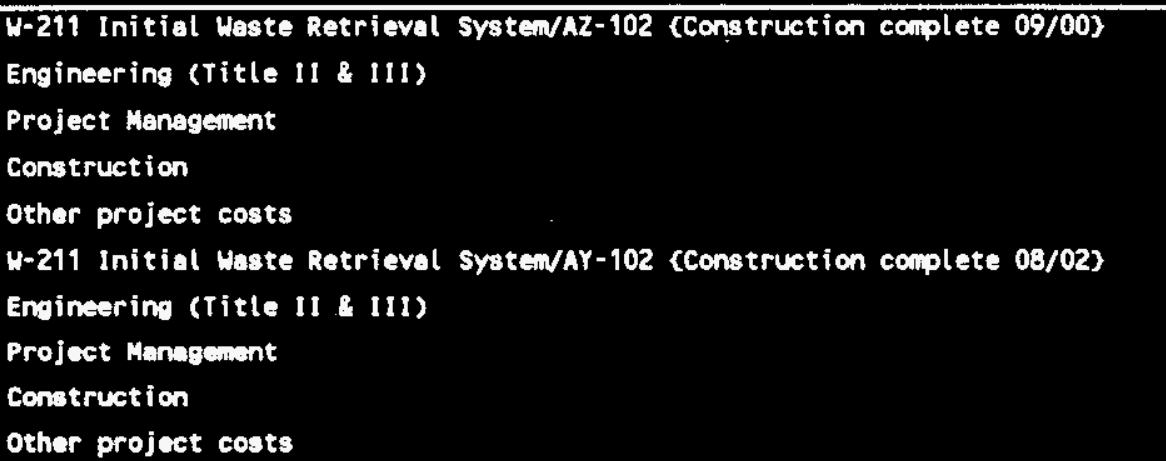 & & $\begin{array}{r}5,160 \\
1,820 \\
16,120 \\
3,020 \\
5,420 \\
1,960 \\
20,890 \\
3,020\end{array}$ & \\
\hline \multicolumn{4}{|l|}{ Qperating Costs (Expence and CENRTC) } \\
\hline 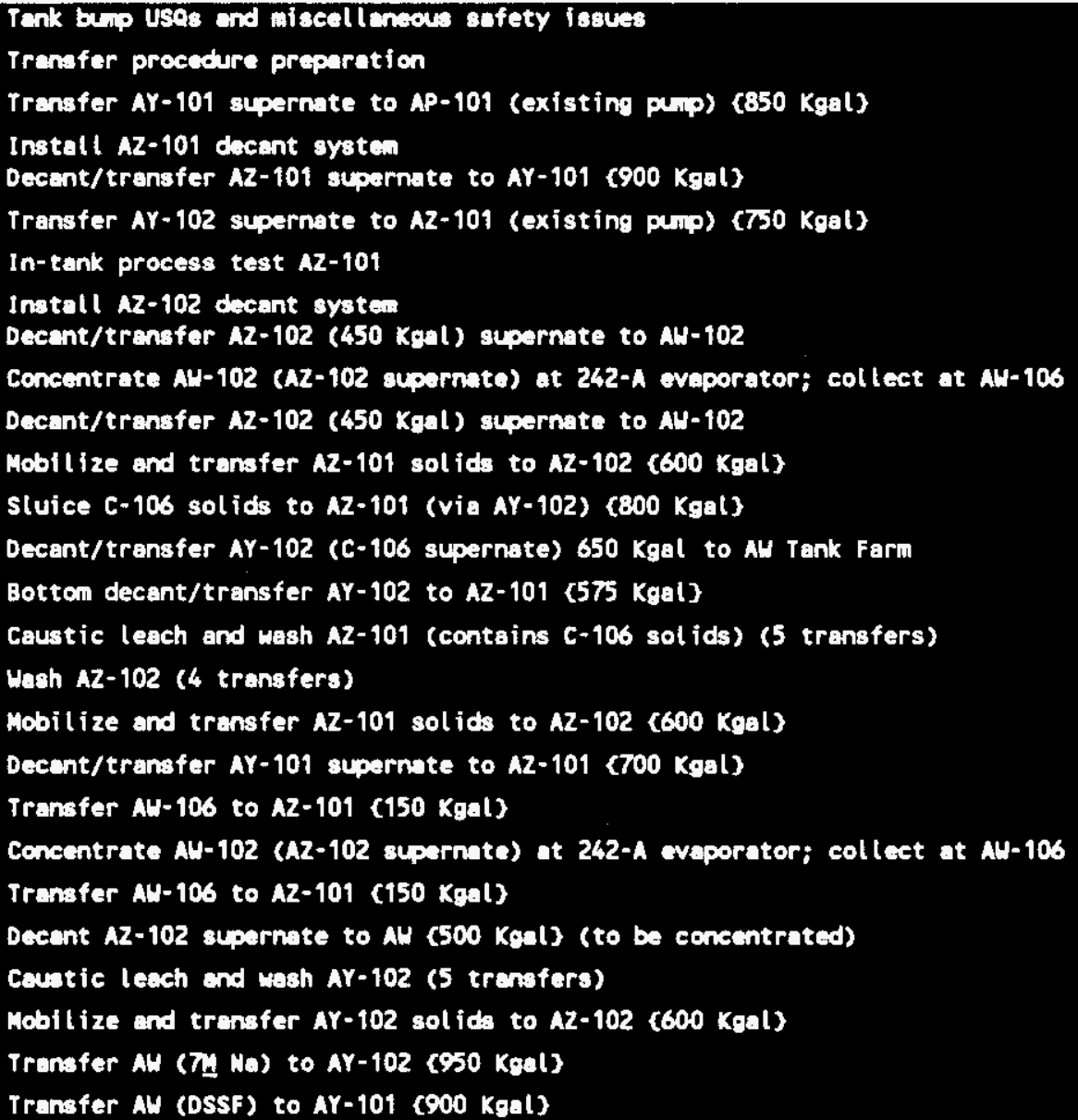 & $\begin{array}{l}\text { (a)(e) } \\
\text { (b) } \\
\text { (a) } \\
\text { (a) } \\
\text { (c) } \\
\text { (b) } \\
\text { (a) } \\
\text { (e) } \\
\text { (a) } \\
\text { (a) } \\
\text { (d) } \\
\text { (a) } \\
\text { (a) } \\
\text { (h) } \\
\text { (h) } \\
\text { (a) } \\
\text { (a) } \\
\text { (a) } \\
\text { (a) } \\
\text { (a) } \\
\text { (e) } \\
\text { (h) } \\
\text { (a) } \\
\text { (a) } \\
\text { (a) }\end{array}$ & 400 & $\begin{array}{r}3,300 \\
279 \\
4,800 \\
400 \\
135 \\
135 \\
5,050 \\
400 \\
80 \\
2,500 \\
80 \\
100 \\
5,400 \\
100 \\
100 \\
3,800 \\
5,900 \\
100 \\
100 \\
80 \\
2,500 \\
70 \\
3,200 \\
3,800 \\
100 \\
100 \\
100\end{array}$ \\
\hline TOTAL COST & & 58,210 & 42,709 \\
\hline
\end{tabular}


ROTE: See footnotes (a) throwh (h) starting on pase $\mathbf{A - 4 8 .}$

(f) In-tank concentration in any of the aging waste tenks is assuned to be accaipl ished with the existing ventilation syetem (U-030). Accompl ishment of this task will require shutdown of the individual tank condensers and ruming the ventilation system chiller condenser system at an increased rate. The chiller condenser systen routes the collected condensate to catch tank 241-A2-151. Puping of the catch tank is a routine 12-Kgal transfer.

In order to punp out catch tank AZ-151 the waste is transferred through line 4605 to diversion box 241-AZ-152. The waste is then routed through line D-602 to the AZ-102-02A punp pit, and through SL-500 to the AX-A valve pit. The waste can either be routed to AU or AP Tank Farns to be staged for eveporation at the 242-A eveporator or be routed to a dilute maste DST receiver tank such as AY-101. It is assuined this operation would last approximately 5 to 6 years for AZ-102.

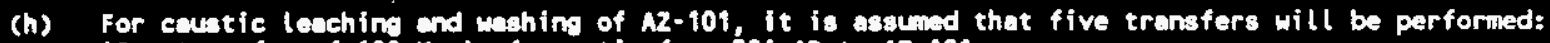
tone transfer of 100 keal of ceustie from 204-AR to $A Z-101$

tone tremefor of $100 \mathrm{Kal}$ of ecustic suparnate to AU for eveporation at the 242-A evaporator at $\$ 5.54 / 001$

*Two trensfors of $500 \mathrm{Keal}$ dilute liquid to Az-101

tone transfor of $500 \mathrm{Kaal}$ to $\mathrm{NU}$ for eveporation ot the 242-A eveporator at $55.54 / \mathrm{gal}$.

For washing of $\mathbf{2 - 1 0 2}$, it is nasund that four transfers will be parforineds

*Two tremfors of 500 kat dilute liquid to Az-102

two trensfers of $500 \mathrm{kgal}$ to AH for eveporation at the 242-A eveporator at $55.54 / 9 a \mathrm{~L}$.

For castic leaching and waning of AY-102, it is assuned that five transfers will be performed:

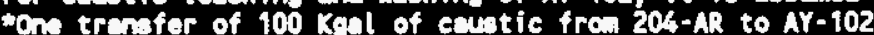

tone trensfer of $100 \mathrm{kgal}$ of ecustic supernate to AU for eveporation the 242-A eveporator at $35.54 / \mathrm{eal}$

-Two trensfers of $500 \mathrm{kad}$ dilute licuid to AY-102

*One trensfer of $500 \mathrm{Keal}$ to AU for evaporation at the 242-A evaporator at $55.54 / \mathrm{gal}$. 
WHC-SD-WM-ER-532

Revision 0

ALTERNATIVE N5b

Consolidation of $A Y-102$ and $A Z$ Tank Farm solids in tank AZ-102.

\begin{tabular}{|c|c|c|c|}
\hline \multicolumn{2}{|l|}{ Project (Copital) } & $\begin{array}{l}\text { CAPITAL } \\
(\$ 000)\end{array}$ & $\begin{array}{l}\text { EXPENSE } \\
(\$ 000)\end{array}$ \\
\hline \multicolumn{2}{|l|}{$\begin{array}{l}\text { U-211 Initial Waste Retrieval Systen/A2-102 (Construction complete 09/00) } \\
\text { Engineering (Title } 11 \text { \& III) } \\
\text { Project Managenent } \\
\text { Construction } \\
\text { Other project costs } \\
\text { U-211 Initial Uaste Rotrieval Syatcan/AY-102 (Construction complete 08/02) } \\
\text { Engineering (Title } 11 \text { \& III) } \\
\text { Project Menegenent } \\
\text { Construction } \\
\text { other project costs }\end{array}$} & $\begin{array}{r}5,160 \\
1,820 \\
16,120 \\
3,020\end{array}$ & \\
\hline \multicolumn{4}{|l|}{ Operating Costs (Expense and CEMRTC) } \\
\hline 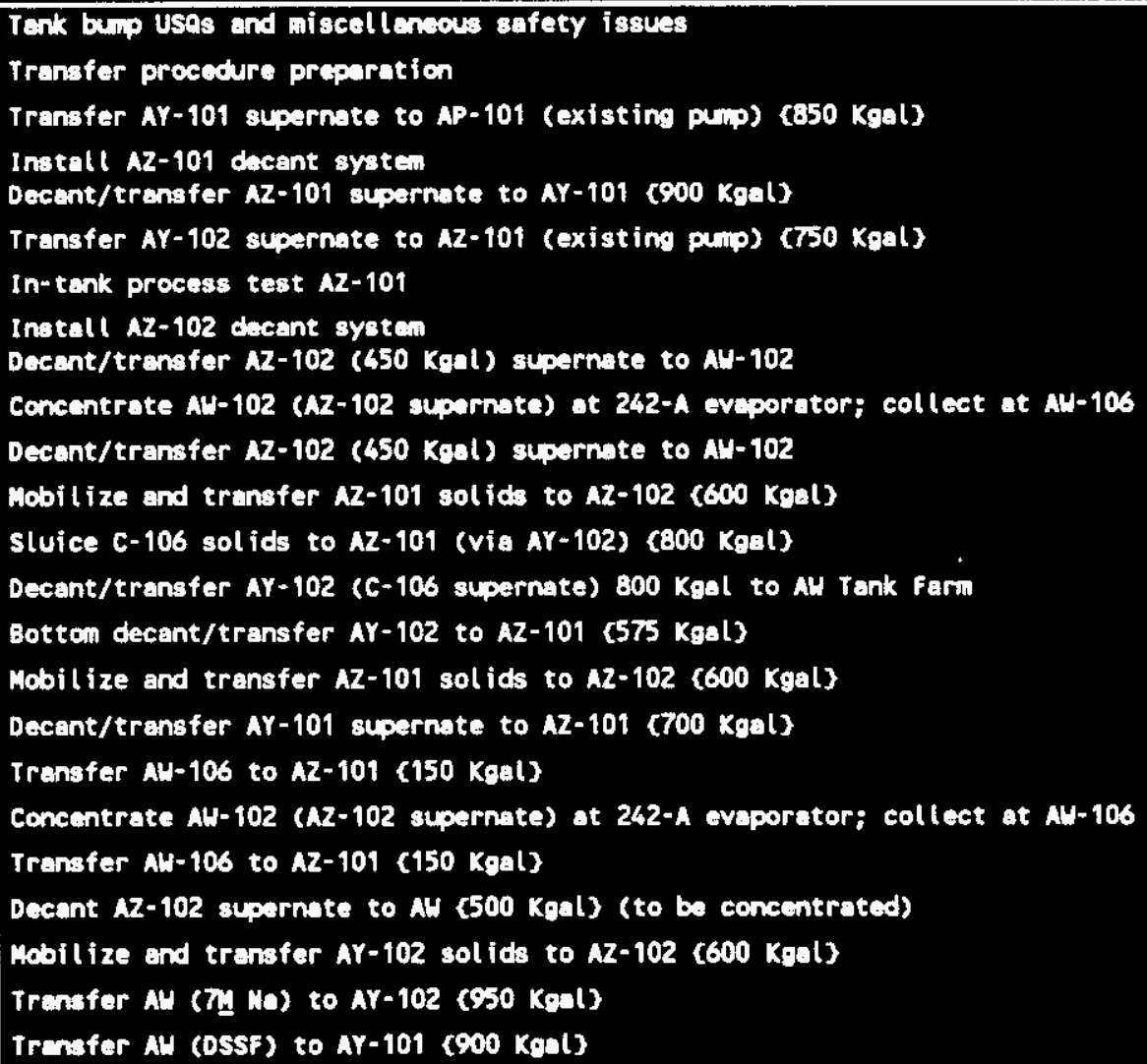 & $\begin{array}{l}\text { (a)(e) } \\
\text { (b) } \\
\text { (a) } \\
\text { (a) } \\
\text { (c) } \\
\text { (b) } \\
\text { (a) } \\
\text { (e) } \\
\text { (a) } \\
\text { (a) } \\
\text { (d) } \\
\text { (a) } \\
\text { (a) } \\
\text { (a) } \\
\text { (a) } \\
\text { (a) } \\
\text { (a) } \\
\text { (a) } \\
\text { (a) }\end{array}$ & 400 & $\begin{array}{r}3,300 \\
279 \\
4,800 \\
400 \\
135 \\
135 \\
5,050 \\
400 \\
80 \\
2,500 \\
80 \\
100 \\
5,400 \\
100 \\
100 \\
100 \\
100 \\
80 \\
2,500 \\
70 \\
3,200 \\
100 \\
100 \\
100\end{array}$ \\
\hline TOTAL Cost & & 38,210 & 29,209 \\
\hline
\end{tabular}

NOTE: See footnotes (a) throwh (h) starting on page $A-48$.

(f) In-tank concentration in any of the aging waste tanks is assumed to be accoupl ished with the existing ventilation system (H-030). Accompl ishwent of this task will require shutdoun of the individual tank condensers and ruming the ventilotion system chiller condenser system at an increased rate. The chiller condenser syatem routes the collected condensate to catch tank 241-A2-151. Punping of the catch tank is a routine 12-Kgal transfor.

In order to punp out eatch tank AZ-151 the waste is trensferred through 1 in 4605 to diversion box 241-A2-152. The waste is then routed through line D-602 to the $A 2-102-02 A$ pup pit, end through SL-500 to the $A X-A$ valve pit. The waste can either be routed to AU or AP Tcnk Farms to be staged for eveporation at the 242-A evaporator or be routed to a dilute waste DST receiver tenk such as AY-101. It is assuned this operation would last epproxinately 5 to 6 years for AZ-102. 
WHC-SD-WM-ER-532

Revision 0

ALTERNATIVE 5c

Consolidation of $A Y-101$ and $A Z$ Tank Farm sol ids in tank AZ-102.

\begin{tabular}{|c|c|c|c|}
\hline \multicolumn{2}{|l|}{ Project (Cepital) } & $\begin{array}{l}\text { CAPITAL } \\
(5000)\end{array}$ & $\begin{array}{l}\text { ENSE } \\
\text { 100) }\end{array}$ \\
\hline 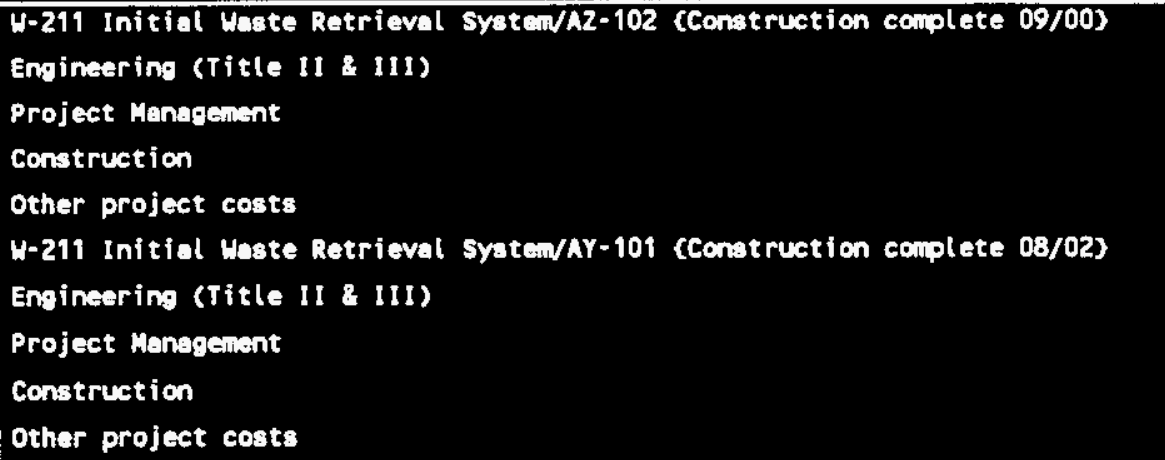 & & $\begin{array}{r}5,160 \\
1,820 \\
16,120 \\
3,020 \\
5,420 \\
1,960 \\
20,890 \\
3,020\end{array}$ & \\
\hline \multicolumn{4}{|l|}{ Operating Costs (Expense and CENRTC) } \\
\hline 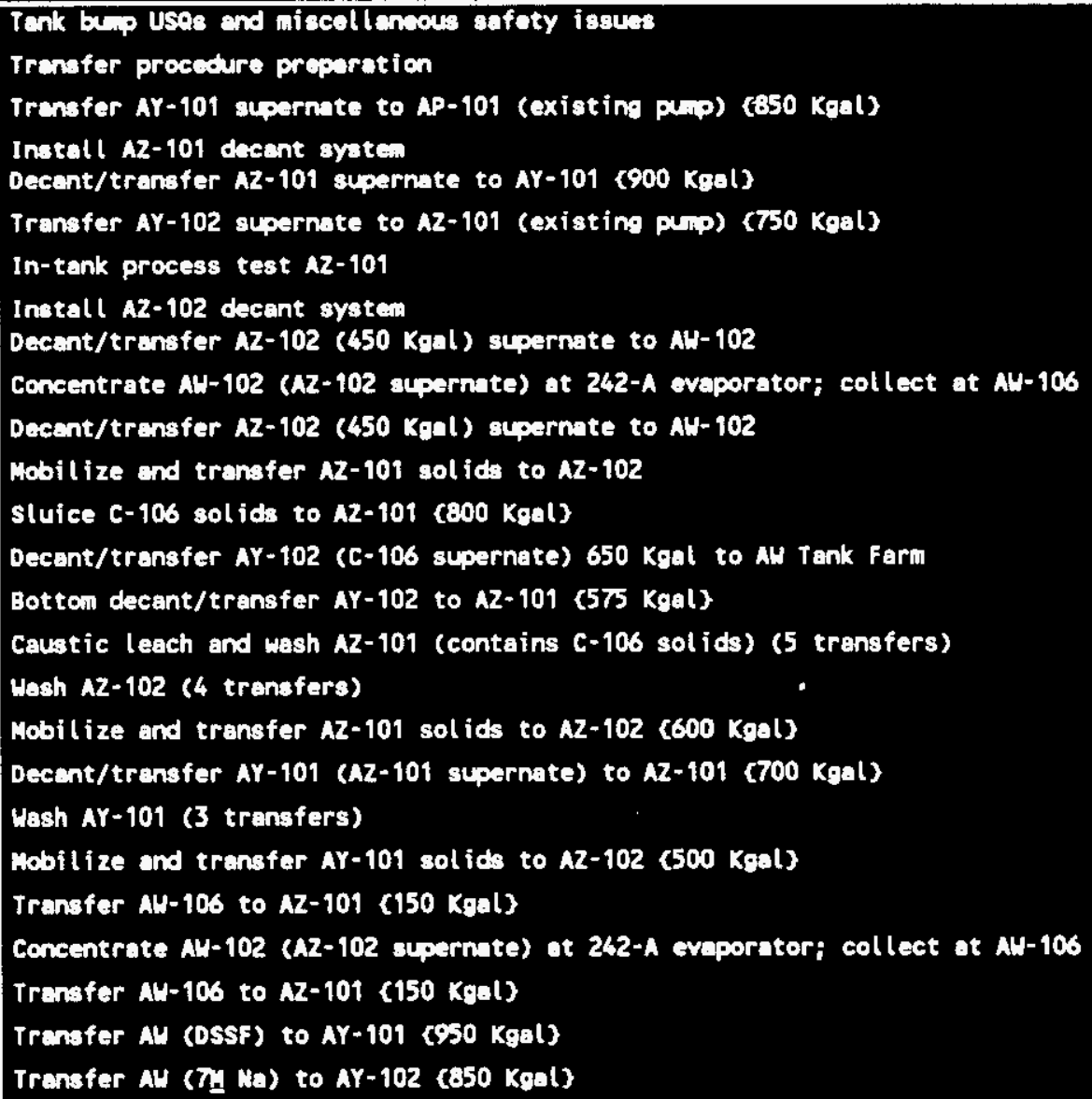 & $\begin{array}{l}\text { (a)(e) } \\
\text { (b) } \\
\text { (a) } \\
\text { (a) } \\
\text { (c) } \\
\text { (b) } \\
\text { (a) } \\
\text { (e) } \\
\text { (a) }\end{array}$ & 400 & $\begin{array}{r}3,500 \\
252 \\
4,800 \\
400 \\
135 \\
135 \\
5,050 \\
400 \\
80 \\
2,500 \\
80 \\
100 \\
5,400 \\
100 \\
100 \\
3,800 \\
5,900 \\
100 \\
100 \\
2,300 \\
100 \\
80 \\
2,500 \\
70 \\
100 \\
100\end{array}$ \\
\hline TOtAL cost & & & \\
\hline
\end{tabular}


WOTE: See footnotes (a) throwh (h) starting on page $A-48$.

(f) In-tank concentration in any of the aging waste tanks is assumad to be accouplished with the oxisting ventilation systein (U-030). Accompl ishniant of this task will require shutdown of the individual tenk condensers and ruming the ventilation system chiller condenser system at an increased rate. The chiller condenser systein routes the collected condensate to catch tank 241-AZ-151. Puiping of the catch tank is a routine 12-Kgal transfer.

In ordar to pup out catch tank $A 2-151$ the waste is transferred through tine 4605 to diversion box 241-AZ-152. The wate is then routed throuph line D-602 to the AZ-102-02A pulp pit, and through $S L-500$ to the $\mathbf{A X}-A$ valve pit. The waste can either be routed to AU or AP Tank Farms to be staged for eveporation ot the $242-A$ evaporator or be routed to a dilute waste DST receiver tenk such as AY-101. It is assund this operation would last epproxinately 5 to 6 years for AZ-102.

(h) For eaustic lesching and wahing of Az-101, it is assuned that five transfers will be parformed: tons tranfer of $100 \mathrm{Kal}$ of cautic from 204-AR to AZ-101

tone tremsfor of $100 \mathrm{Keal}$ cautic auparnate to AU for evaporation at the 242-A eveporator at $35.54 / \mathrm{sal}$

*Two tremefers of $500 \mathrm{kal}$ dilute liquid to $\mathrm{A2}-101$

* One trensfer of $500 \mathrm{Keal}$ to AU for. evaporation at the $242-\mathrm{A}$ evaporator at $55.54 / \mathrm{gal}$. For washing of $\boldsymbol{M Z}-102$, it is essund that four trensfers uill be perforiseds

"Two transfers of $500 \mathrm{kal}$ dilute liquid to Az-102

*Two trensfor of $500 \mathrm{xasl}$ to $A M$ for eveporation at the $242-A$ eveporator at $\$ 5.54 / 9 \mathrm{al}$.

For washing of $A Y-101$, it is essuned that three transfers uill be parformed:

"Two tremsfers of $400 \mathrm{keal}$ dilute liquid to AY-101

tone trensfer of $400 \mathrm{Koal}$ to AU for oveporation at $242-\mathrm{A}$ evaporator at $55.54 / \mathrm{gal}$. 
WHC-SD-WM-ER-532

Revision 0

ALTERNATIVE N5C

Consolidation of $A Y-101$ and $A Z$ Tank Farm solids in tank AZ-102.

\begin{tabular}{|c|c|c|c|}
\hline \multicolumn{2}{|l|}{ Project (Capital) } & $\begin{array}{l}\text { CAPITAL } \\
(\$ 000)\end{array}$ & $\begin{array}{l}\text { EXPENSE } \\
(\$ 000)\end{array}$ \\
\hline \multicolumn{2}{|l|}{ 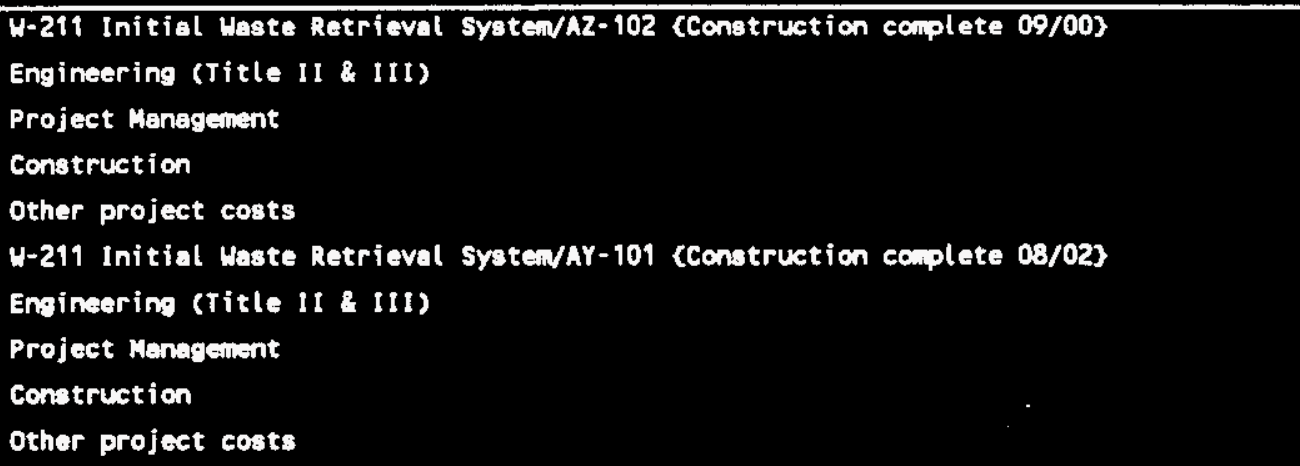 } & $\begin{array}{r}5,160 \\
1,820 \\
16,120 \\
3,020 \\
5,420 \\
1,960 \\
20,890 \\
3,020\end{array}$ & \\
\hline \multicolumn{4}{|l|}{ Operating Coats (Expenae and CENRTC) } \\
\hline 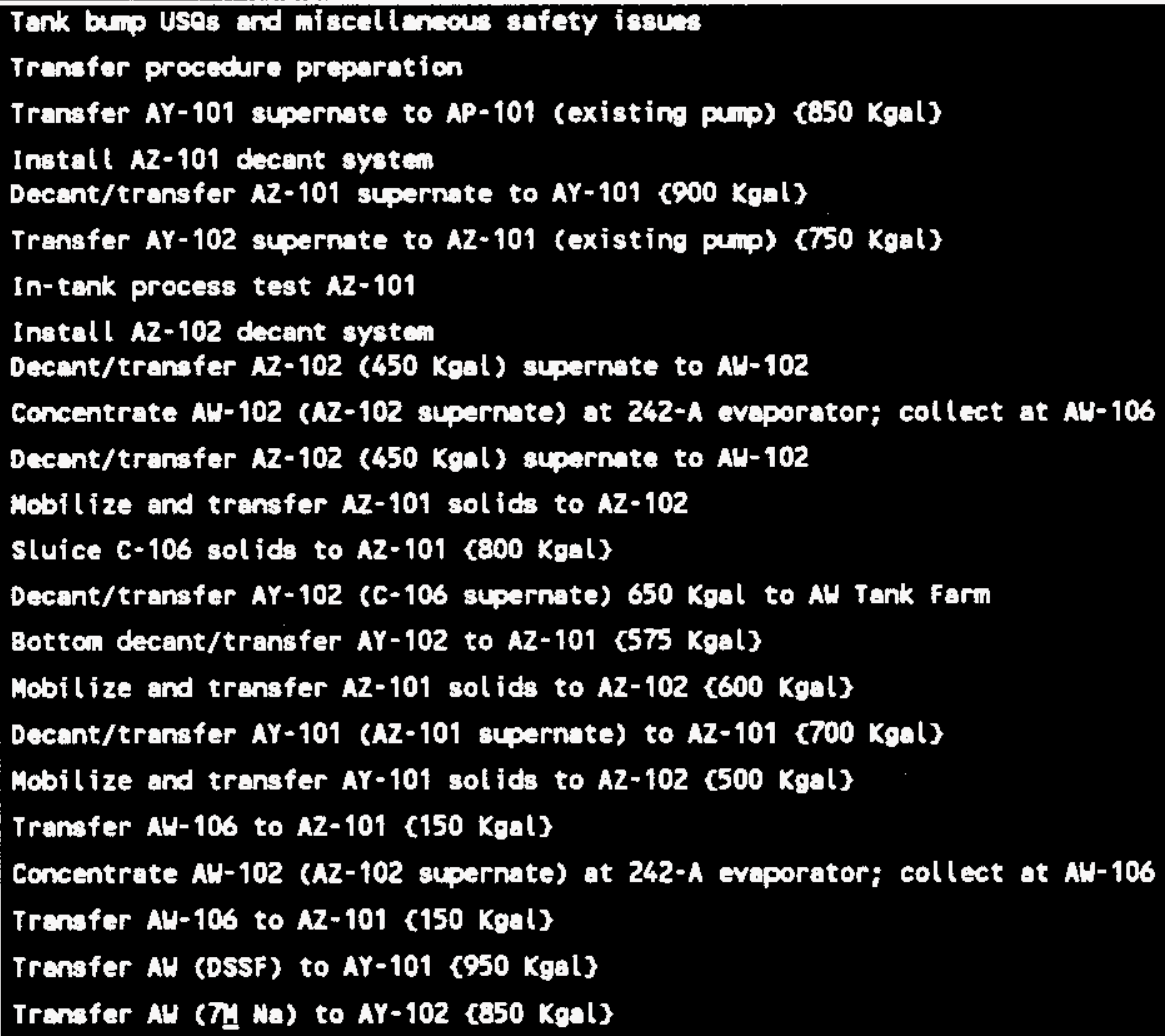 & $\begin{array}{l}(a)(e) \\
(b) \\
(a) \\
(a)\end{array}$ & 400 & $\begin{array}{r}3,500 \\
252 \\
4,800 \\
400 \\
135 \\
135 \\
5,050 \\
400 \\
80 \\
2,500 \\
80 \\
100 \\
5,400 \\
100 \\
100 \\
100 \\
100 \\
100 \\
80 \\
2,500 \\
70 \\
100\end{array}$ \\
\hline TOTAL CosT & & & \\
\hline
\end{tabular}

WOTE: See footnotes (a) through $(h)$ starting on pase $A-48$.

(f) In-tank concentration in any of the agin uaste tenks is ossuind to be accouplished with the existing ventilation systen (H-030). Accompl ishwent of this task will require shutdoun of the individual tenk condensers and ruming the ventilation system chiller condenser systea at an increased rate. The chiller condenser system routes the collected condensate to eatch tank 241-AZ-151. Punping of the catch tank is a routine 12-Kgal tranafer.

In order to $p$ mp out catch tank AZ-151 the waste is trensferred throuph line 4605 to diversion box 241-AZ-152. The waste is then routed throukh Iine D-602 to the $A 2-102-02 A$ pup pit, and through SL-500 to the AX-A valve pit. The wate cen either be routed to AU or AP Tank farms to be staged for evaporation at the 242-A eveporator or be routed to a dilute wate DST receiver tank such as AY-101. It is assinad this operation would lest epproxinately 5 to 6 years for AZ-102. 
WHC-SD-WM-ER-532

Revision 0

\section{ALTERNATIVE 6}

Consolidation of $A Z$ Tank Farm sol ids in tank $A Z-102$.

\begin{tabular}{|c|c|c|c|}
\hline \multicolumn{2}{|l|}{ Project (Cepital) } & $\begin{array}{l}\text { CAPITAL } \\
(\$ 000)\end{array}$ & \\
\hline 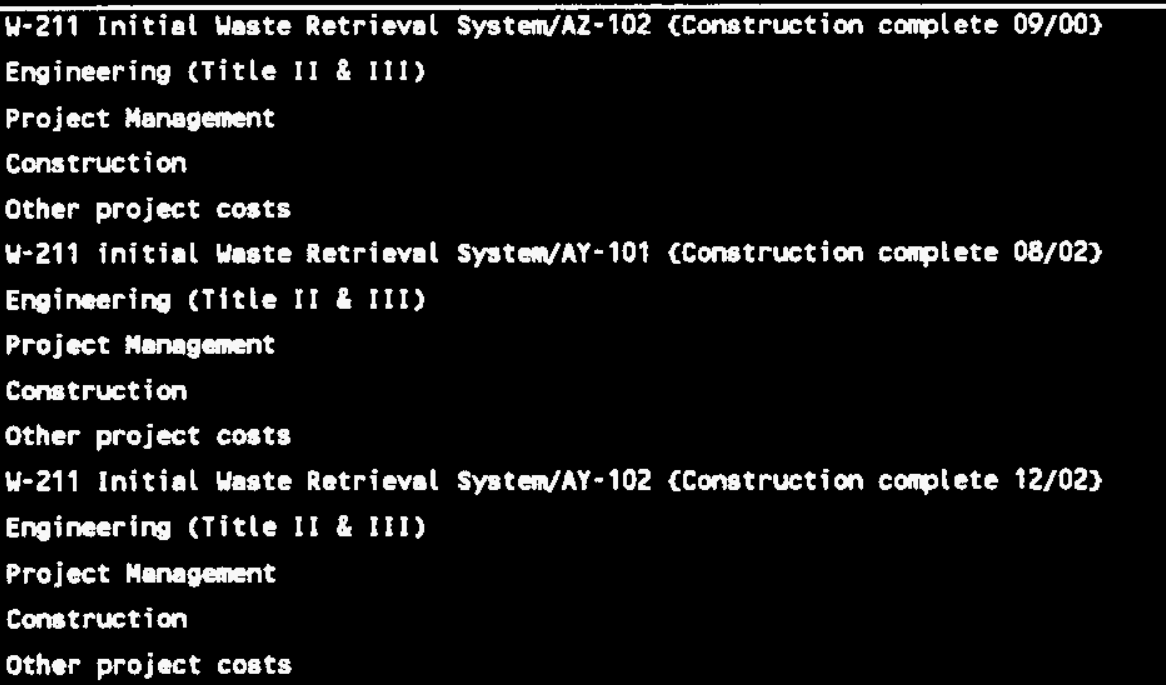 & & $\begin{array}{r}5,420 \\
1,960 \\
20,890 \\
3,020 \\
5,420 \\
1,960 \\
20,890 \\
3,020\end{array}$ & \\
\hline \multicolumn{4}{|l|}{ Cperating Costs (Expense and CEURTC) } \\
\hline 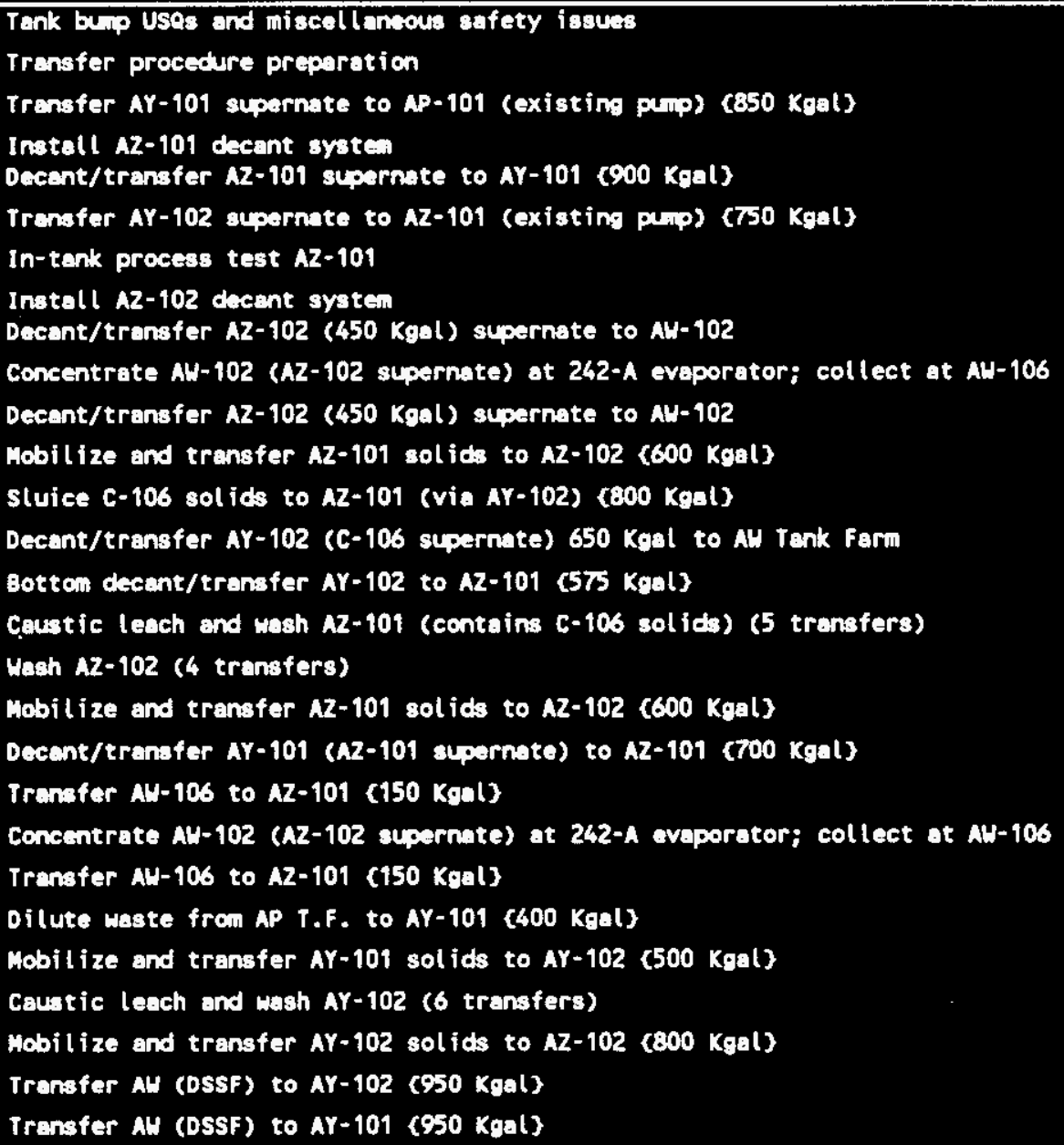 & $\begin{array}{l}\text { (a) } \\
\text { (b) } \\
\text { (a) } \\
\text { (a) } \\
\text { (c) } \\
\text { (b) } \\
\text { (a) } \\
\text { (e) } \\
\text { (a) } \\
\text { (a) } \\
\text { (d) } \\
\text { (a) } \\
\text { (a) } \\
\text { (b) } \\
\text { (b) } \\
\text { (a) } \\
\text { (a) } \\
\text { (a) } \\
\text { (a) } \\
\text { (a) } \\
\text { (a) } \\
\text { (a) } \\
\text { (b) } \\
\text { (a) } \\
\text { (a) }\end{array}$ & 400 & $\begin{array}{r}3,900 \\
270 \\
4,800 \\
400 \\
135 \\
135 \\
5,050 \\
400 \\
80 \\
2,500 \\
80 \\
100 \\
5,400 \\
100 \\
100 \\
3,800 \\
5,900 \\
100 \\
100 \\
80 \\
2,500 \\
70 \\
100 \\
100 \\
6,140 \\
100 \\
100 \\
100\end{array}$ \\
\hline TOTAL COST & & 89,500 & 42,640 \\
\hline
\end{tabular}


WOTE: See footnotes (a) throwh (h) starting on page $A-48$.

(f) In-tank concentration in eny of the aging wate tanks is assuned to be accomplished with the oxisting ventilotion syatem (H-030). Acecopl ishiment of this teak will requi re shutdown of the individual tenk condenaers and ruming the ventilation system chiller condenser system at an increased rate. The chiller condenser system routes the collected condensate to catch tank 241-Az-151. Pumping of the cateh tank is a routins 12-Kgal transfer.

In order to pump out eatch tenk $A z-151$ the waste is transferred through line 4605 to diversion box 241-AZ-152. The waste is then routed throuh line D-602 to the AZ-102-02A pump pit, and through SL-500 to the $\mathbf{X}-\mathbf{A}$ valve pit. The waste cen either be routed to AM or AP Tonk farms to be staged for evaporation at the 242-A evaporator or be routed to a dilute waste DST receiver tank such as AY-101. It is assund this operation would last epproxinately 5 to 6 years for $A 2-102$.

(h) For caustic leaching and wahing of AZ-101, it is assuned that five transfers will be performed: tone trensfer of $100 \mathrm{Koal}$ of caustic from 204-NR to $A 2-101$

wone tranfer of ecustic aupernate out of $100 \mathrm{~K} \cdot \mathrm{al}$ to AH for evaporation ot the 242-A evaporator at $35.54 / \mathrm{eal}$

tTwe tremefers of $500 \mathrm{keal}$ dilute liquid to $\mathrm{Az}-101$

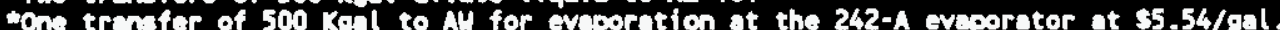

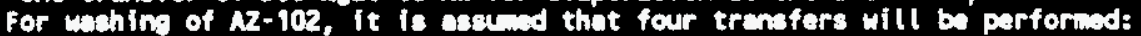

tTwo trensfers of 500 kesl dilute liquid to $\mathbf{A Z}-102$

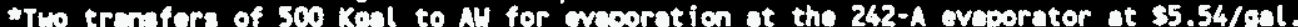

For cautic lesching ond wahing of AY-102, it Is easend that six trensfers will be performed:

tone trenter of $100 \mathrm{koal}$ of enestic from $204-\mathrm{AR}$ to $A Y-102$

tone trenafer of ceutic supernate out of $100 \mathrm{Keal}$ to AU for evaporation ot the 242-A evcporator at $35.54 / \mathrm{eal}$

"Two transfers of $750 \mathrm{Koal}$ dilute liquid to AY-102

tone trenafer of $750 \mathrm{Kad}$ to AU for evaporation at the 242-A evaporator at $55.54 / 9 a \mathrm{~L}$

tone transfer of $150 \mathrm{kgal}$ to AU for evaporation at the 242-A evaporator at $35.54 / 9 \mathrm{al}$. 
WHC-SD-WM-ER-532

Revision 0

ALTERNATIVE N6

Consolidation of $A Z$ tank farm solids in tank $A Z-102$.

\begin{tabular}{|c|c|c|c|}
\hline Project (Capital) & & & \\
\hline 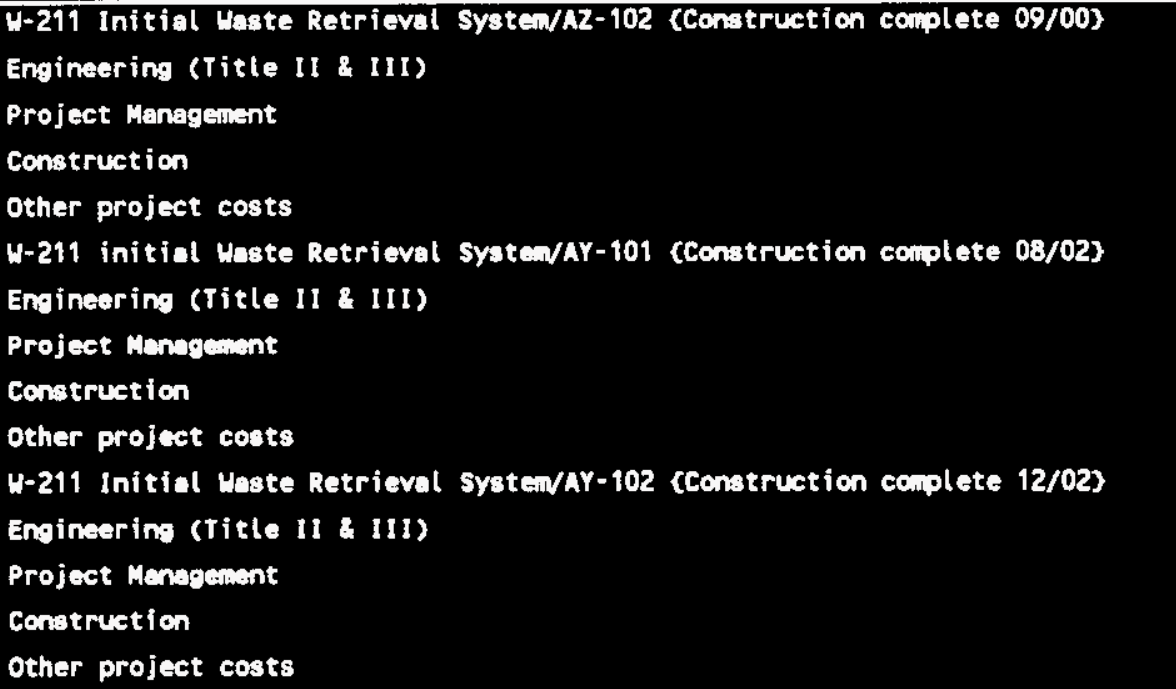 & & $\begin{array}{r}5,420 \\
1,960 \\
20,890 \\
3,020 \\
5,420 \\
1,960 \\
20,890 \\
3,020\end{array}$ & \\
\hline Operating Costs (Expense and CENRTC) & & & \\
\hline 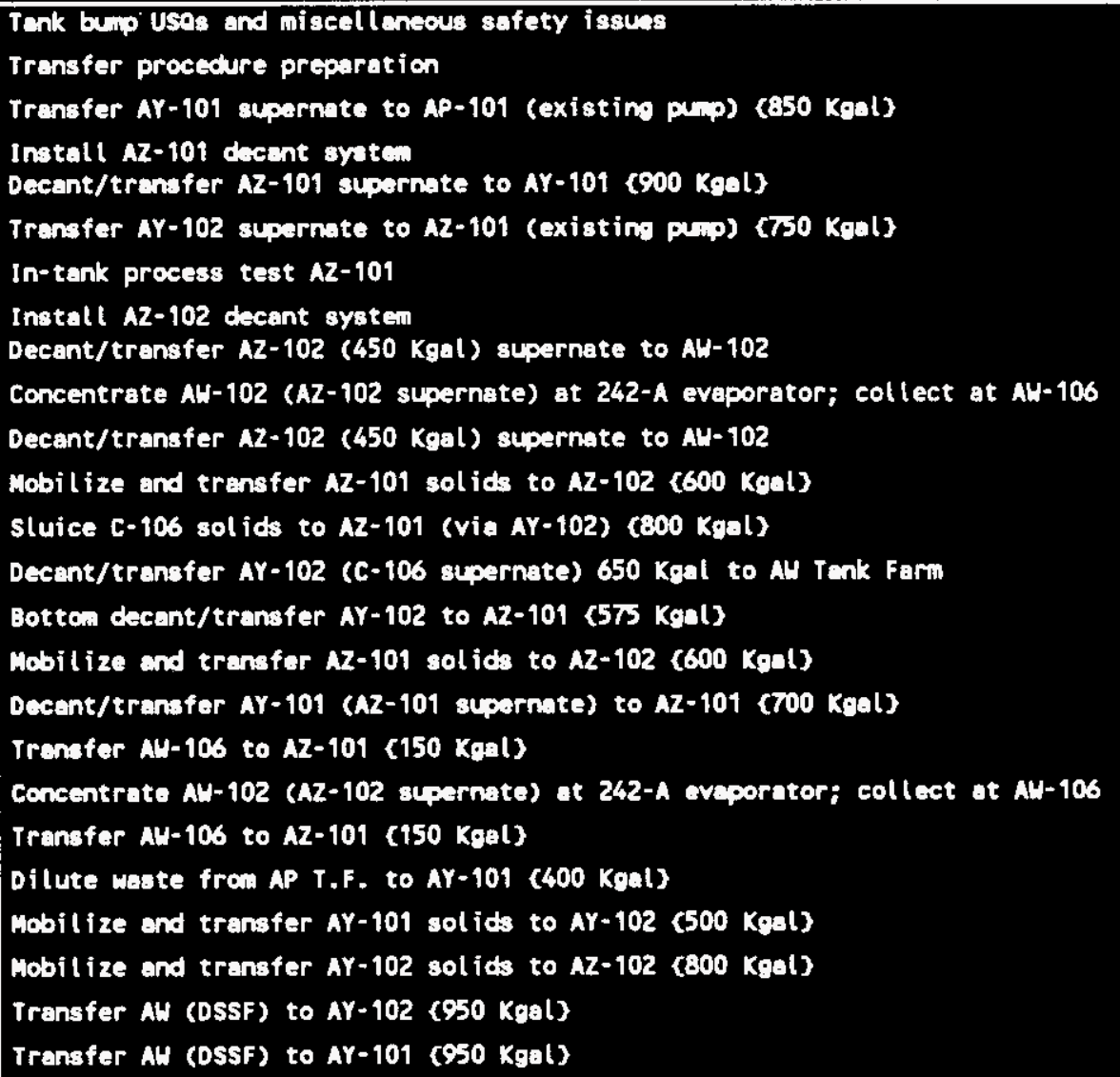 & $\begin{array}{l}\text { (b) } \\
\text { (g) } \\
\text { (e) }\end{array}$ & 400 & $\begin{array}{r}3,900 \\
270 \\
4,800 \\
400 \\
135 \\
135 \\
5,050 \\
400 \\
80 \\
2,500 \\
80 \\
100 \\
5,400 \\
100 \\
100 \\
100 \\
100 \\
80 \\
2,500 \\
70 \\
100 \\
100 \\
100 \\
100 \\
100\end{array}$ \\
\hline TOTAL COST & & & 26,800 \\
\hline
\end{tabular}


NOTE: See footnotes (a) throwh (h) starting on pase A-48.

(f) In-tank concentration in any of the aging waste tanks is aseunis to be accouplished with the existing ventilation systen $(U-030)$. Accoipl ishment of this task will require shutdown of the individual tenk condensers and ruming the ventilation system chiller condeneer system at an increased rate. The chiller condenser systen routes the collected condensute to catch tank 241-A2-151. Puming of the catch tank is a routine 12-Kgal transfer.

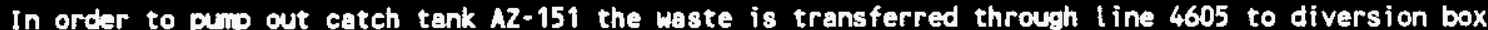
241-Az-152. The waste is then routed through line D-602 to the $A 2-102-02 A$ punp pit, and through SL-500 to the $\boldsymbol{A X}-\mathbf{A}$ valve pit. The waste cen either be routed to AU or AP Tank Farms to be staged for eveporation at the 242-A eveporator or be routed to a dilute waste DST receiver tank such as AY-101. It is assuasd this operation would last epproxinately 5 to 6 years for AZ-102. 
WHC-SD-WM-ER-532

Revision 0

ALTERNATIVE $7 \mathbf{a}$

Transfer C-106 solids sluiced into AY-102 and immediately transfer the sol ids into tank $A Z-101$.

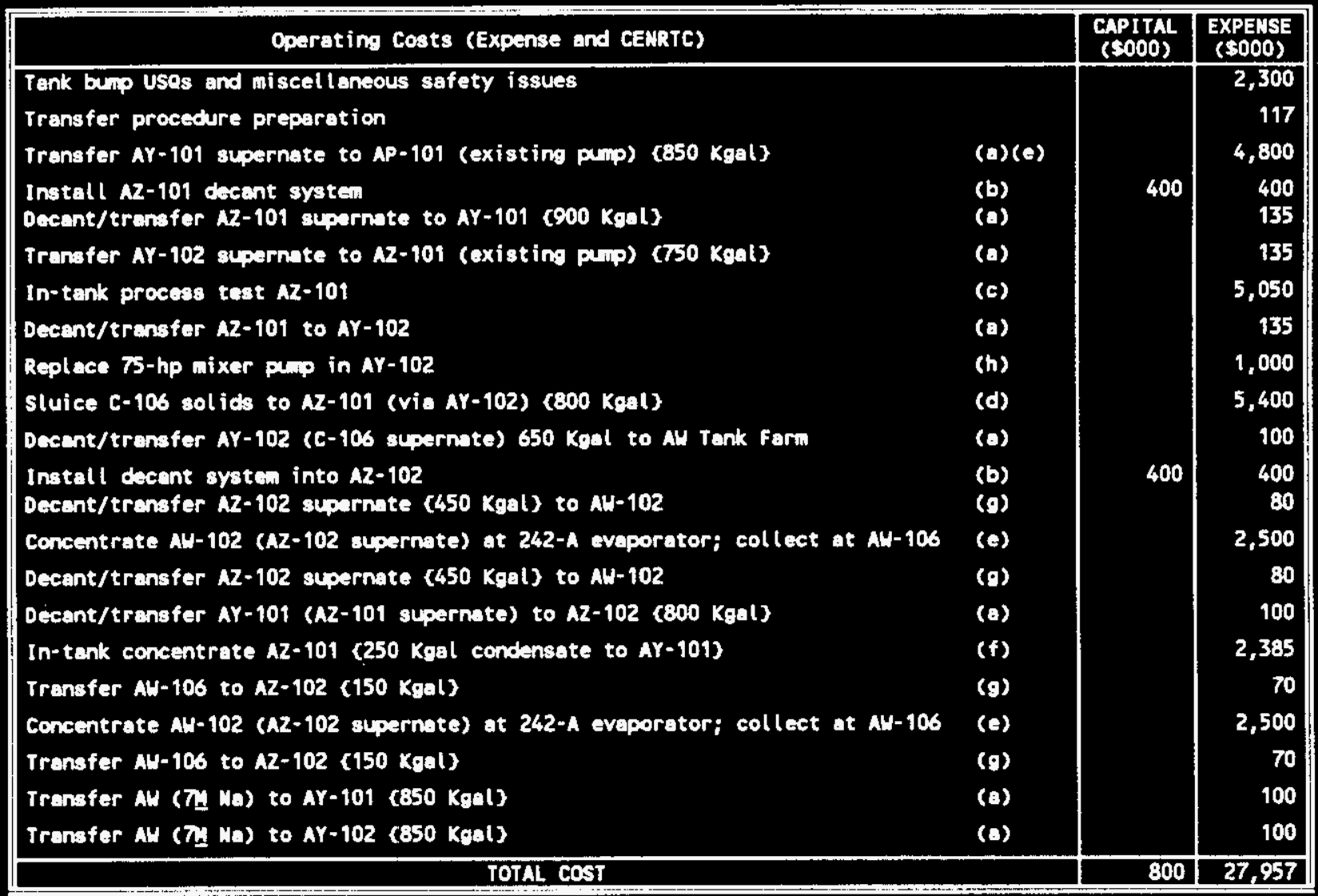

WOTE: See footnotes (a) through (h) starting on page A-48.

(f) In-tank concentration in any of the aging waste tanks is assuned to be accomplished with the existing ventilotion system $(U-030)$. Accompl fahnent of this task will recuire shutdown of the individual tank condensers and ruming the ventilation system chiller condenser system at an incressed rate. The chiller condenser syotem routes the collected condensate to catch tank 241-Az-151. Puping of the catch tenk is a routine 12-kgal transfer.

In order to pump out catch tank AZ-151 the waste is transferred through line 4605 to diversion box 241-AZ-152. The waste is then routed through line D-602 to the AZ-102-02A pulp pit, and through $S L-500$ to the $A X-A$ valve pit. The wate en either be routed to $A M$ or $A P$ Tank farms to be staged for evaporation at the 242-A evaporator or be routed to a dilute uaste DST receiver tenk such as AY-101. It is assund this operation would last approximately 1 to 2 years for AZ-102.

(h) The current 75-hp aixer pup has failed and meeds to be replaced. The unit cost for a new mixer pump is estimated to be 3350K. The cost to rewove the failed mixer, place it into a burial container, end disposal of the pup as solfd wate is susox. These volues include the procurenent of the burial container, labor for renovel, transport of container to solid waste, and the burial cost. 
WHC-SD-WM-ER-532

Revision 0

ALTERMATIVE 7b

Transfer C-106 solids sluiced into AY-102 and immediately transfer the solids into tank $A Z-101$.

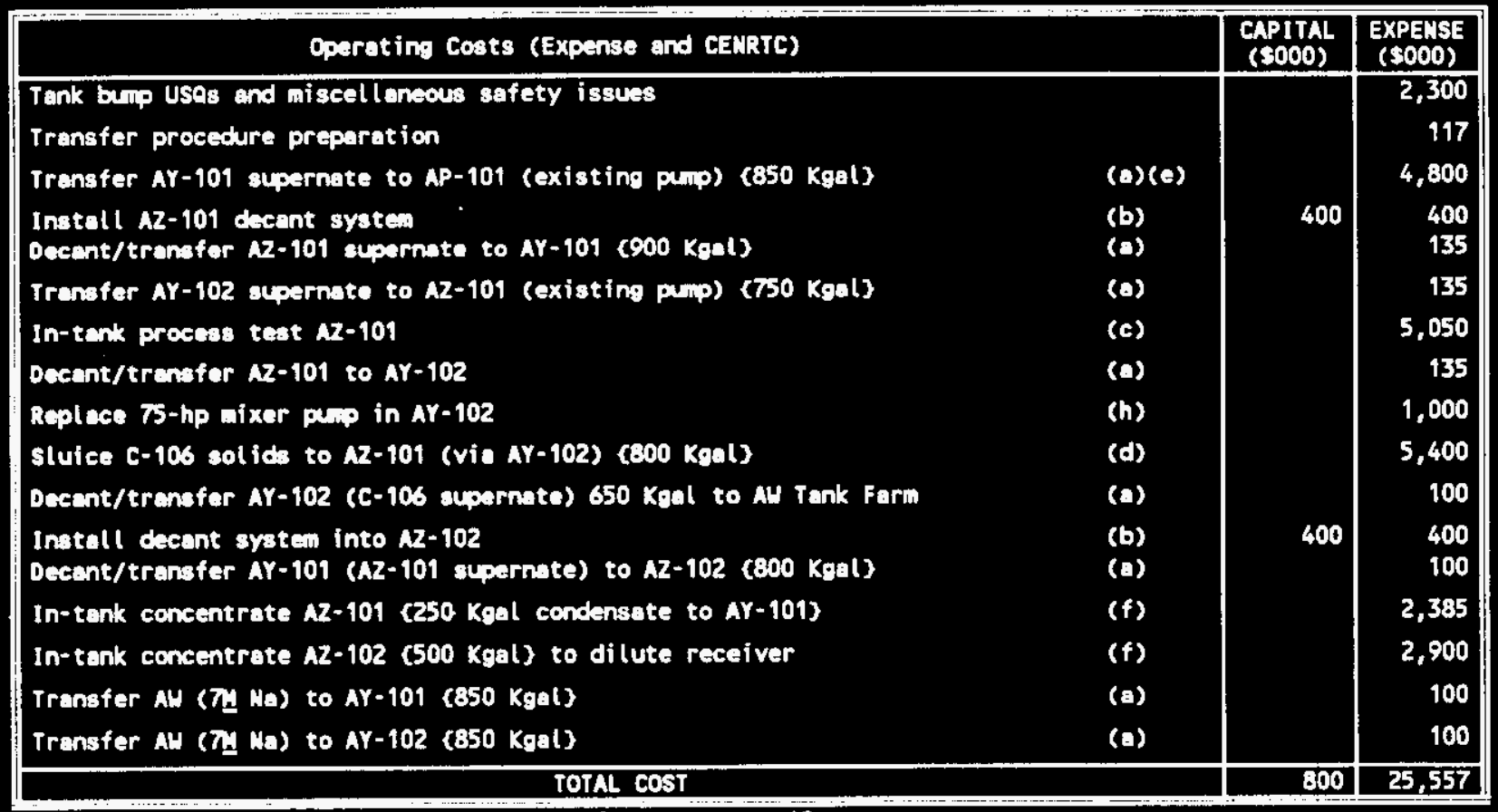

MOTE: See footnotes (a) throwh $(h)$ starting on pege $A-48$.

(f) In-tank concentration in any of the aging wate tanks is assuniad to be accompl ished with the existing ventilation system $(U-030)$. Acccipl f shment of this task will require shutdown of the individul tenk condensers and ruming the ventilation system chiller condenser system at an increased rate. The chiller condenser system routes the collected condensate to catch tank 241-A2-151. Puiping of the catch tank is a routine 12-Koal transfer.

In ordar to pump out catch tank $A Z-151$ the waste is transferred through line 4605 to diversion box 241-AZ-152. The waste is then routed through line $0-602$ to the $A Z-102-02 A$ punp pit, and through St-500 to the AX-A valve pit. The waste cen either be routed to AM or AP Tank farms to be staged for evaporation at the 242-A eveporator or be routed to a dilute waste DST receiver tank such as AY-101. It is assund this operation would last epproxinately 1 to 2 years for $A 2-101$. It is assuned this operation would last approxinately 5 to 6 years for AZ-102.

(h) The current $75-h p$ wixer pup has failed end meds to be replaced. The unit cost for a new mixer pun is eatinated to be 3350K. The cost to remove the failed mixer, place it into a burial container, and disposal of the pew as solid mate is $3650 K$. These values include the procurenent of the burial centainer, labor for removal, tremport of container to solid waste, and the burial cost. 
WHC-SD-WM-ER-532

Revision 0

\section{FOOTNOTES}

(a) Assumes that one waste sample is required before each transfer at a cost of \$70K.

Setup of a waste transfer route requires entering into existing process pits and making jumper changes. Each pit entry is assumed to cost approximately $\$ 10 \mathrm{~K}$ for field personnel support. It is assumed that rigid jumpers will be constructed to provide the greatest routing flexibility for all transfers required to support the alternative implementation; therefore, it is assumed that the initial routing setups will incur the greatest cost burden to install the routes. To support this philosophy, it is assumed that two rigid jumpers will be installed in the $A X$ and $A$ valve pits to support waste transfers to and from the AN and AP Tank Farms.

The cost for workforce support of a transfer is assumed to be two employees per 24-hour period at a cost of \$2.4K.

It is assumed that all transfers are accomplished at a pumping rate of $100 \mathrm{gal} / \mathrm{min}$.

Average time span for waste transfers is approximately 5 days: each day is assumed to be a 24-hour period. For a conservative approach, it is assumed that each transfer will cost approximately \$135K. Therefore, the initial setup of a route is $\$ 135 \mathrm{~K}$ and return transfers are estimated to be \$100K.

(b) Cost for installation of a decant pump system including instrumentation, controllers, installation, and project management. These costs were obtained from the $\mathrm{W}-151$ process test management team.

(c) It is assumed per internal memo 73520-95-032, Process Design, to G. A. Meyer from G. T. MacLean, Westinghouse Hanford Company, Richland, Washington, September 6, 1995, that the AZ-101 process test will be performed in FY96 (5/96-8/96). The costs include installation of equipment not included in Project $\mathrm{W}-151$. Additionally, the costs cover labor that will be required to support the testing of mixer pumps and the transfer of waste as discussed in the aforementioned letter.

(d) It is assumed by Project $W-320$ that sluicing of $C-106$ will require approximately 2 years to perform. This time frame includes operator training, sluicing operation, and D\&D for the operating system. The total cost is estimated to be $\mathbf{5 5 . 4 M}$. Performance period and cost information was provided by the $\mathrm{N}-320$ management team via cc:Mail from T. Shaw.

(e) This waste will be concentrated in the 242-A evaporator at an estimated cost of \$5.54/gal of throughput. Cost per gallon estimate was provided via cc:Mail by T. W. Seifert.

(f) Refer to specific note with Alternative. 
(g) Transfer of supernate waste is estimated using the following assumptions:

- One sample will be required for each transfer at $\$ 70 \mathrm{~K}$ each

- One day (24-hours) support by two personnel is estimated to be $\$ 2.4 \mathrm{~K}$

- The transfer rate is assumed to be $100 \mathrm{gal} / \mathrm{min}$.

- The duration for the various transfers is:

- 450,000 gal - 3 days

- 50,00 gal -- 8 hours

- Additionally, it is assumed that no pit entries will be required to set up the route.

(h) Refer to specific note with Alternative.

GENERAL NOTE:

Volumes are estimated to the nearest 50,000 gal.

\section{DEFINITION OF TERMS}

CENRTC Capital equipment not related to construction

D\&D Decontamination and decomissioning

DSSF

Double-shell slurry feed

DST

FY Double-shell tank

Fiscal year

USQ Unresolved safety question 
WHC-SD-WM-ER-532

Revision 0

This page intentionally left blank. 
WHC-SD-WM-ER-532

Revision 0

APPENoIX B

\section{SCHEDULE}

B-1 
WHC-SD-WM-ER-532

Revision 0

This page intentionally left blank.

B-2 
WHC-SD-WM-ER-532

Revision 0

APPENDIX B

SCHEDULE

\section{Schedules}

Schedules contain. the major operational steps in each alternative such as liquid and solids transfers between tanks. The schedules also include other major activities such as concentration of liquids, and in-tank operations such as leaching and washing.

Project schedules have a significant impact on the schedules for each alternative. The projects for installing initial retrieval systems (mixer pumps and retrieval systems) have the biggest impact on each of those alternatives which include retrieval and transfer of solids. In addition to retrieval and transfer of solids, mixing systems are essential to those alternatives which include in-tank washing and leaching. appendix.

Detailed schedules for each alternative may be found at the end of this

\section{Assuintions}

Existing project schedules were used to determine the schedule for equipment installation. In some projects, flexibility in the sequence of events is possible if decisions are made well in advance of implementation. In particular, Project $\mathrm{W}-211$ installs mixer pump systems in several tanks. In each alternative, Project $W-211$ installs mixer pumps in tanks SY-102 and AW-105 before installing mixer pump systems in any of the AY and AZ tanks. After the first two tanks are installed, the order of mixer pump installation is determined by choosing the tanks that will result in the earliest completion of the operations within the alternative. The time between installation of mixer pump systems in each tank is about 1 year.

Project $\mathrm{W}-320$ installs the retrieval system in tank $\mathrm{C}-106$. This system is designed to retrieve the solids from $C-106$ into AY-102. Changing from AY-102 to some other receiver tank will change the project completion date between 7 to 12 months from the existing late fiscal year (FY) 1996 completion date.

Project $W-151$ is scheduled to complete installation of a mixer pump system into tank AZ-101 in FY 1996. Changing this project to put the mixer pumps into another tank is unfeasible at this late date.

Retrieval of solids from $\mathrm{C}-106$ requires 3 to 4 months. Mixer pump transfer of solids from one double-shell tank to another requires about 2 months. Decanting 1 iquid from one tank to another requires about 1 month. Leaching of solids requires about 6 months. Washing of solids requires about 4 months. 
Concentration of supernate in Evaporator 242-A does not impact schedules in the $A Z$ and $A Y$ Tank Farms because the evaporator is expected to have excess capacity during periods of waste consolidation.

Alternatives $5 a, 5 b$ and $5 c$

Alternatives 5a, 5b, and $5 \mathrm{c}$ are similar to the planning alternative (5a) (Bacon 1995). Transfers depend on the installation or availability of pumps and transfer routes. Many of these transfer systems are provided by projects, and project completion becomes the enabling action required before many of the transfers can be initiated. The phystcal transfer of waste from one tank to another requires up to 2 weeks. The time allotted to transfers in the schedules is longer to accomnodate sampling and analysis of solutions before transfer as we11 as other operating, maintenance, and process control support activities which are a part of each transfer.

Based on the projected operating schedule of Project $\mathrm{W}-320$, sluicing of C-106 solids to AZ-101 via AY-102 will require as long as 9 months to complete. Other activities requiring longer schedules include leaching and washing processes which require up to 9 months to complete. Washing of solids without leaching requires a minimum of 3 months.

\section{Alternatives $1 \mathrm{a}$ and $1 \mathrm{~b}$}

Alternatives $1 \mathrm{a}$ and $1 \mathrm{~b}$ change the receiver of $\mathrm{C}-106$ retrieved waste from AY-102 to AZ-101. Rerouting the transfer 1 ines from $C-106$ to $A Z-101$ requires 7 to 12 months. All subsequent related activities also will be delayed.

In Alternative 1a, in-tank concentration of AZ-101 supernate in AY-102 requires about 24 months.

\section{Alternative 3}

In Alternative 3, in-tank concentration of supernate in AZ-102 requires about 20 months.

\section{Alternative 4}

Alternative 4 is similar to Alternative 1 except the receiver of C-106-retrieved waste is AZ-102. Leaching and washing in AZ-102 occurs after the installation of the mixer system in FY 2001.

\section{Alternative 6}

Alternative 6 is similar to Alternatives $5 a, 5 b$, and $5 c$. In Alternative 6 , the additional steps of combining, leaching, and washing the solids in tanks AY-101 and AY-102 add about 17 months to the overall schedule.

\section{Comparison of Schedules of Alternatives}

The schedule for each alternative is compared to the desired completion date. The desired completion date is 2001 for having the solids consolidated and ready to feed to disposal processes. The earliest completion date is 1998 for completing Alternative 2. This completion date is given a scale of $100 \%$. 
Completion in 2001 is given a value of $85 \%$. The latest completion date is 2004 for Alternatives $5 \mathrm{~b}, 5 \mathrm{c}$, and 6 . This completion date is given a value of $0 \%$. Other values are Alternatives $1 \mathrm{a}, 3$, and 7 completed in 1999 with a value of $95 \%$. Alternative $0 a$ is given a completion date of 2000 and a value of $90 \%$. Alternatives $0 \mathrm{~b}$ and $5 \mathrm{a}$ are given a completion date of 2001 and a value of $85 \%$. Alternatives $1 \mathrm{~b}$ and 4 are given a completion date of 2002 and a value of $56 \%$. Other alternative end points (the " $N$ " alternatives) are shown at the end of this appendix. In general, the " $N$ " alternatives finish more quickly than do their non-N namesakes because of the deletion of caustic leaching.

\section{REFERENCES}

Bacon, R. F., 1995, Double-Shell Tank Waste Consolidation and Retrieval Planning Base Case (internal memo 73510-95-017 to C. A. Augustine et al., August 29), Westinghouse Hanford Company, Richland, Washington. 
WHC-SD-WM-ER-532

Revision 0

\section{Schedules}

The following schedules at the end of this appendix are target schedules. Many of the activities for waste transfers reflect a time duration of up to 3 months; in most of the cases, the actual transfer will last 5 to 14 days. Therefore, the time frames represented should consider that the activity takes place within the 3-month window identified.

The schedules also assume that jumpers required to make up the routes to support a transfer are available or can be fabricated before the transfer is required. Many of the fumpers are in the planning stage. 


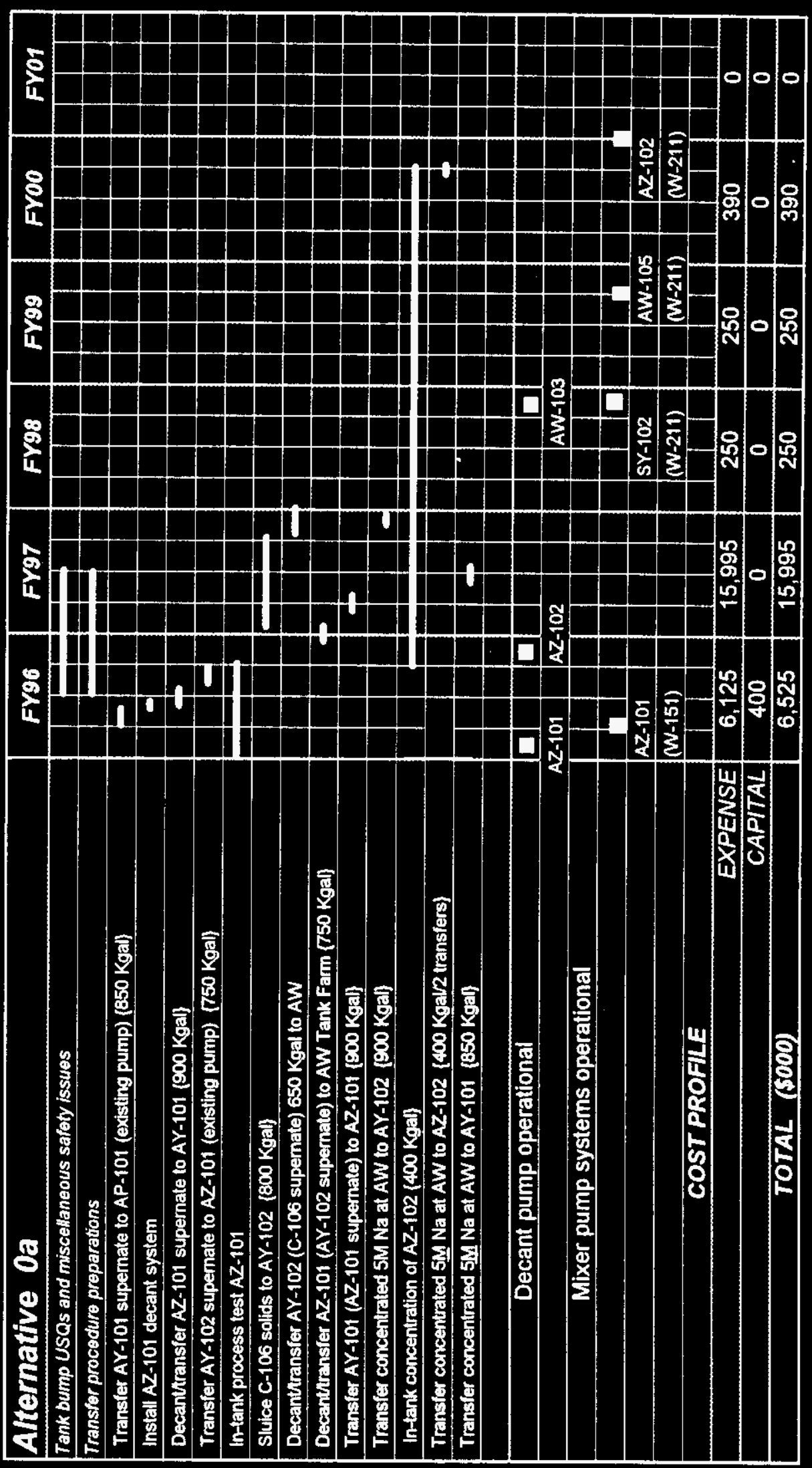




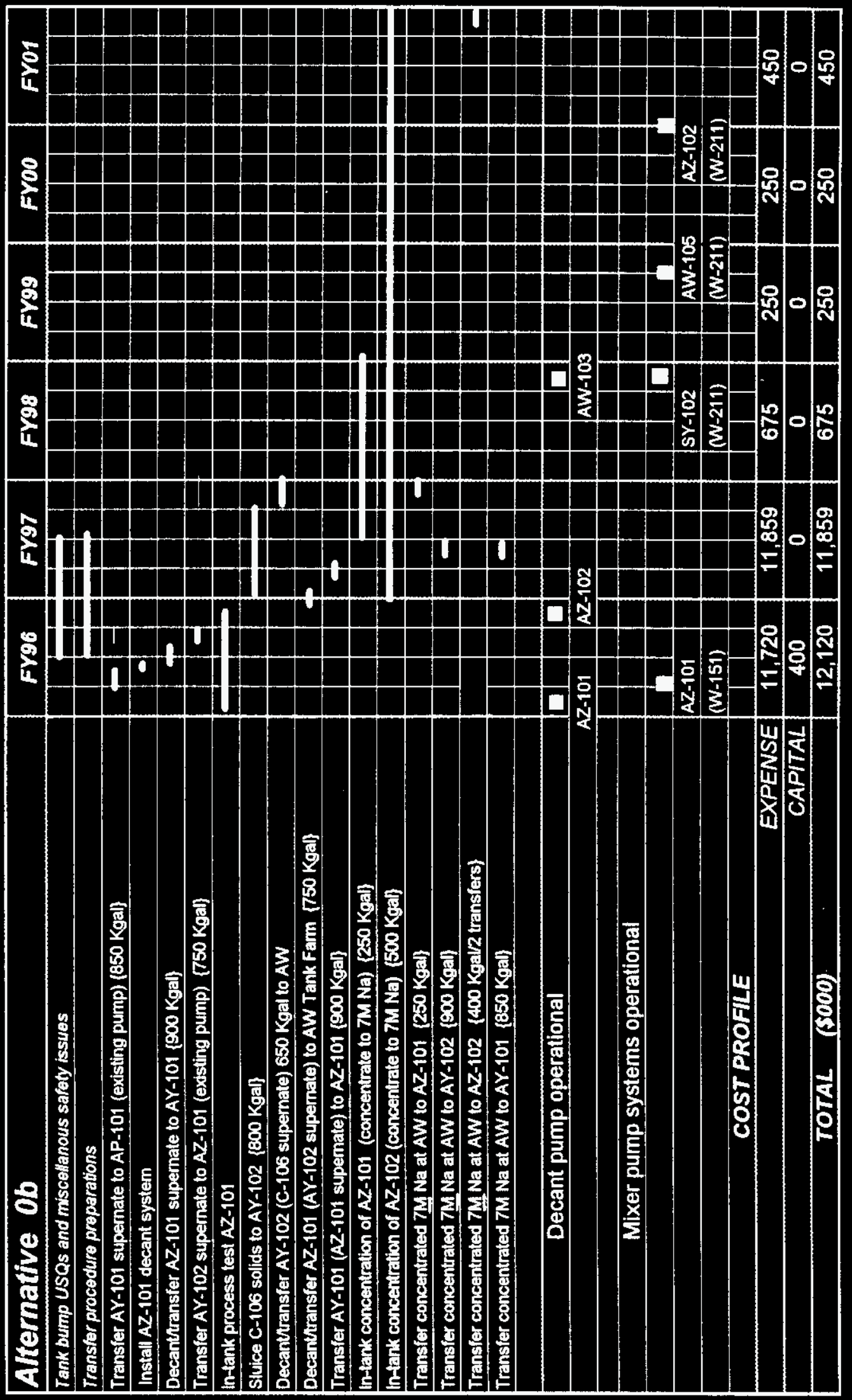




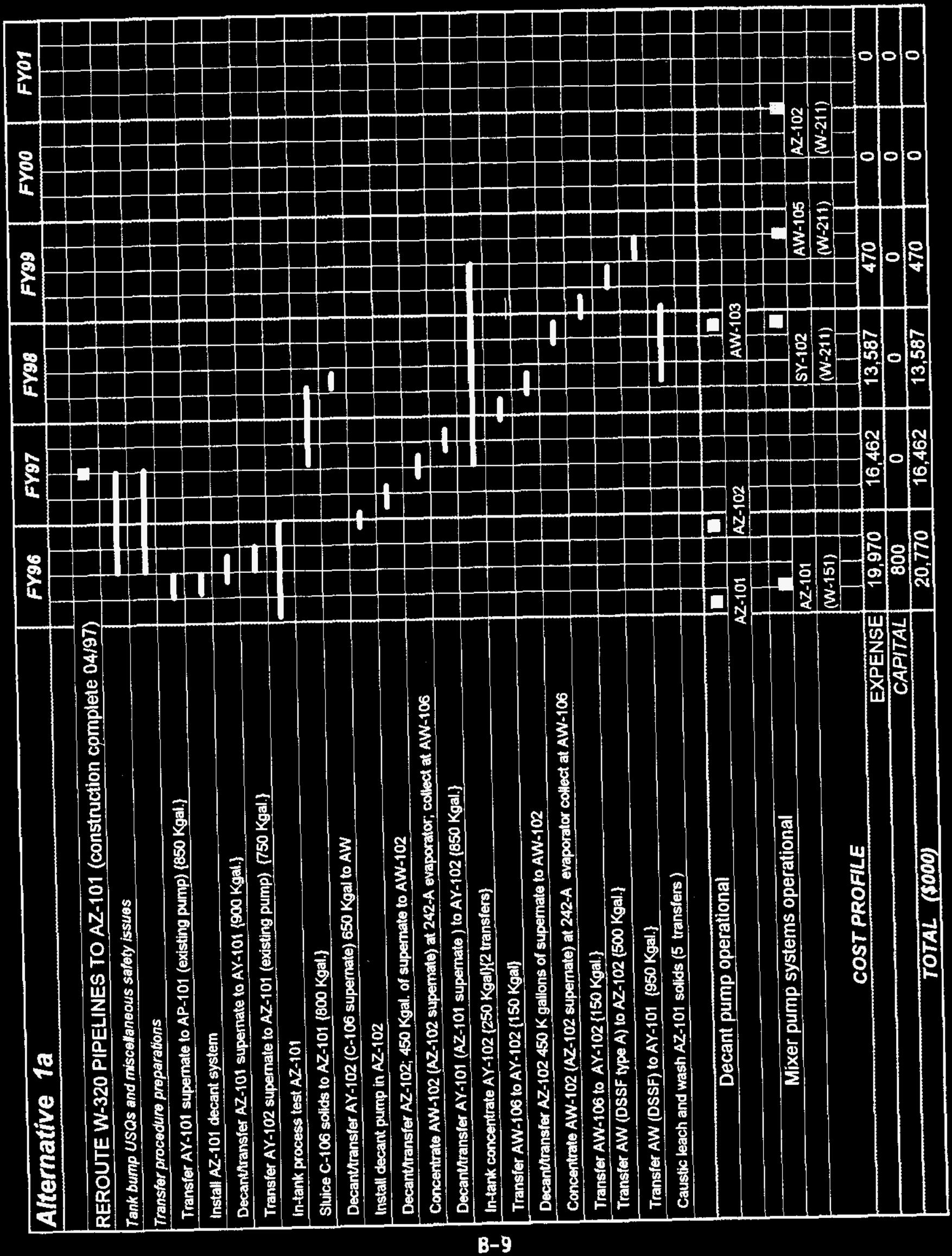




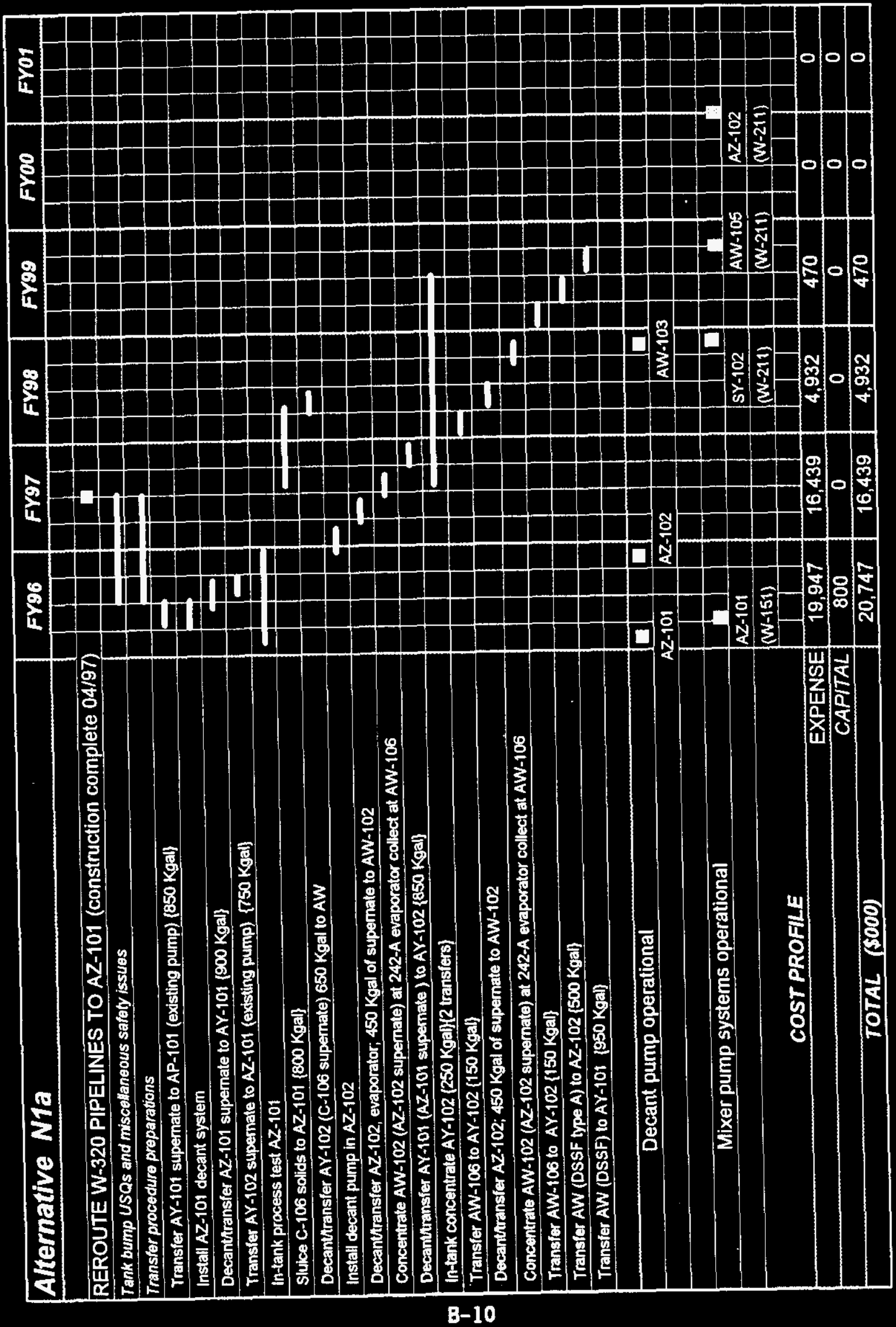




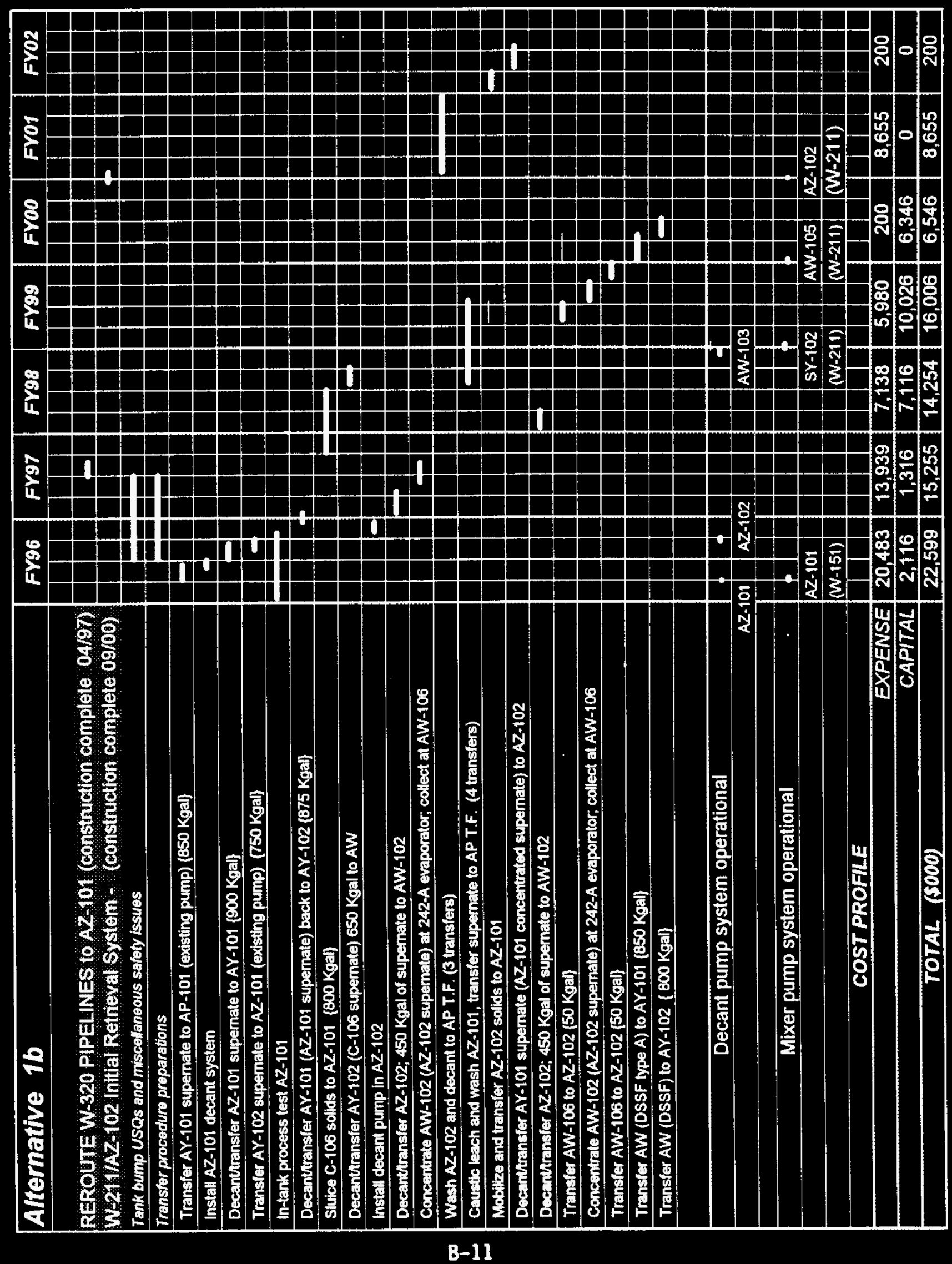




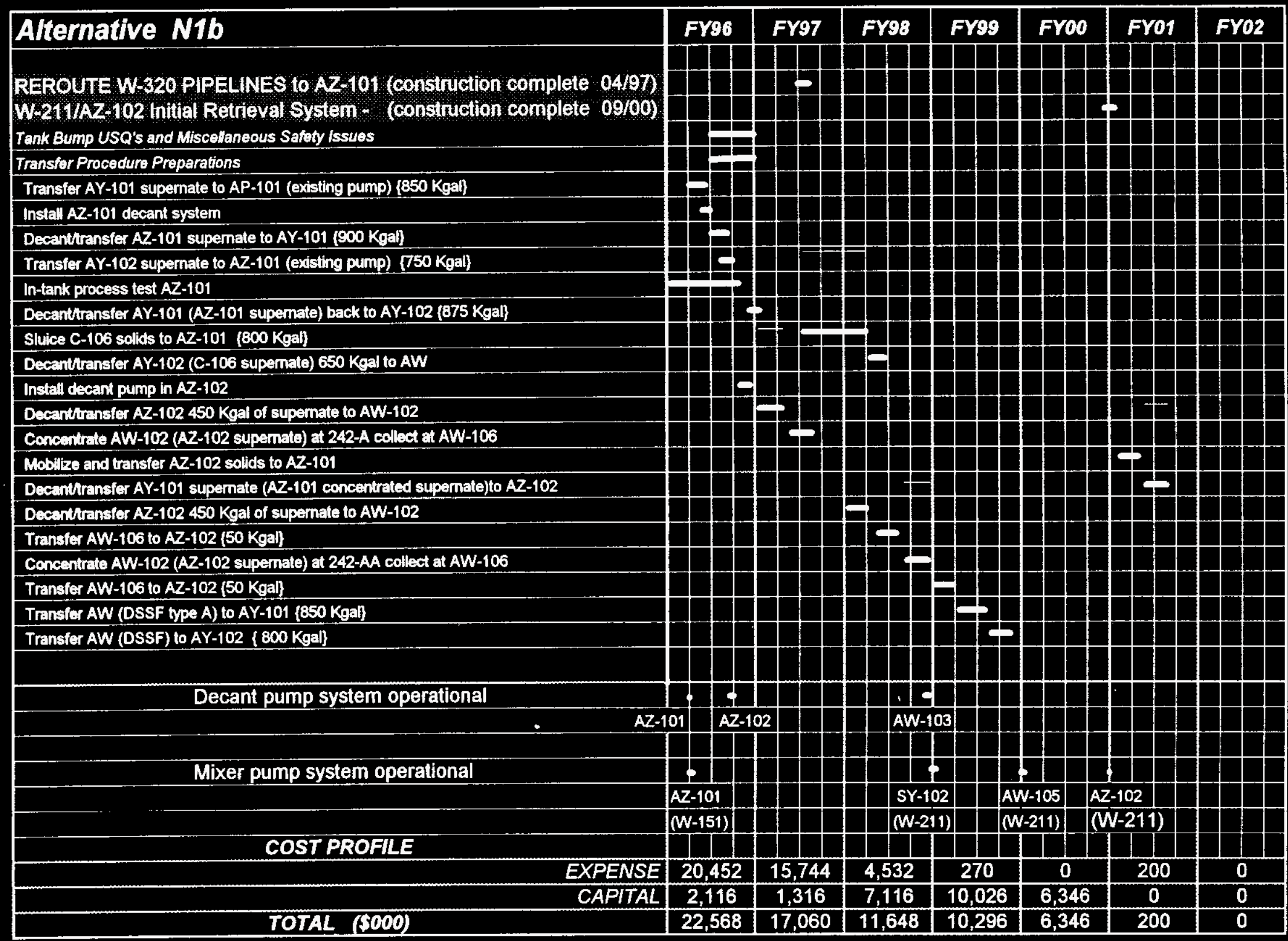




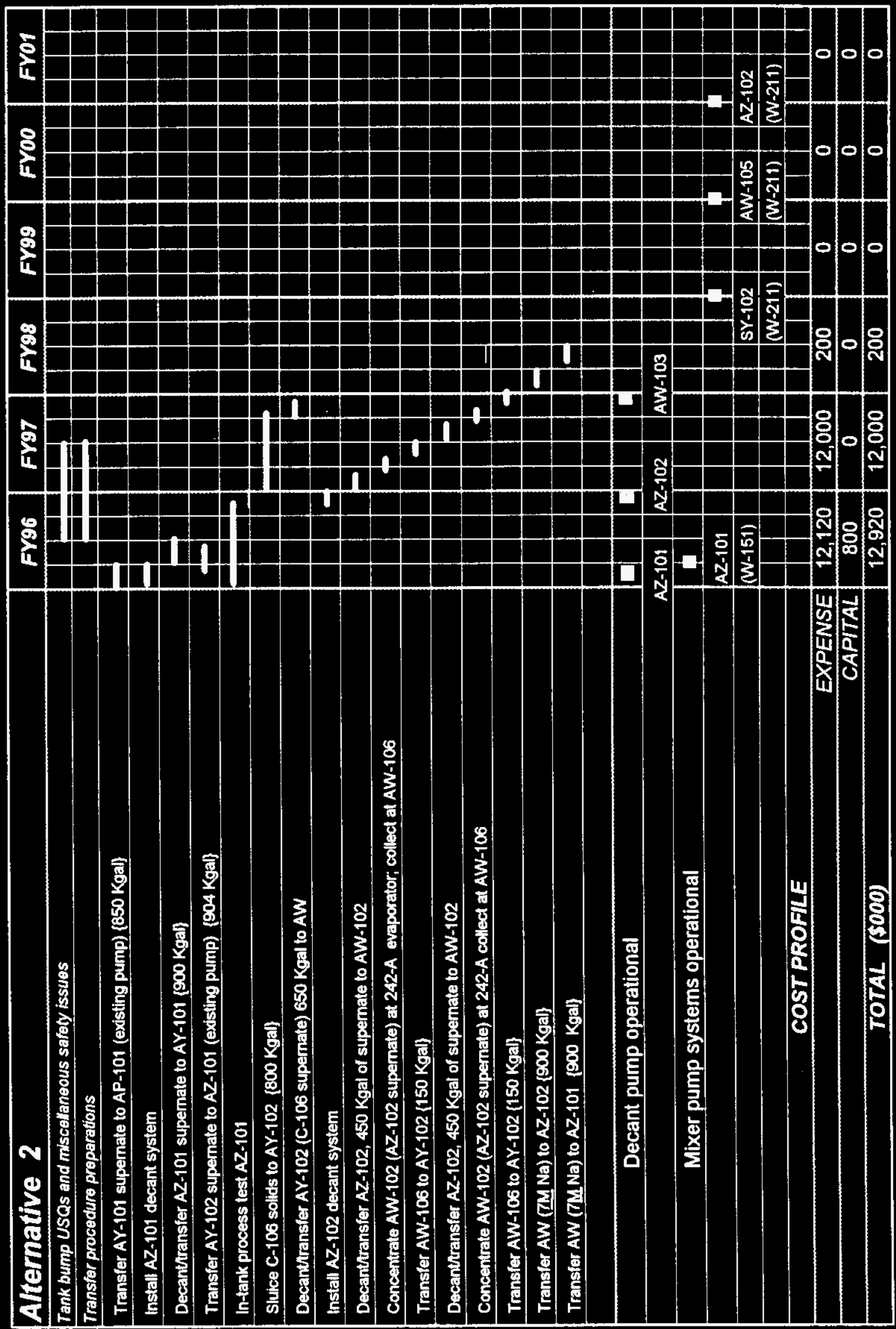




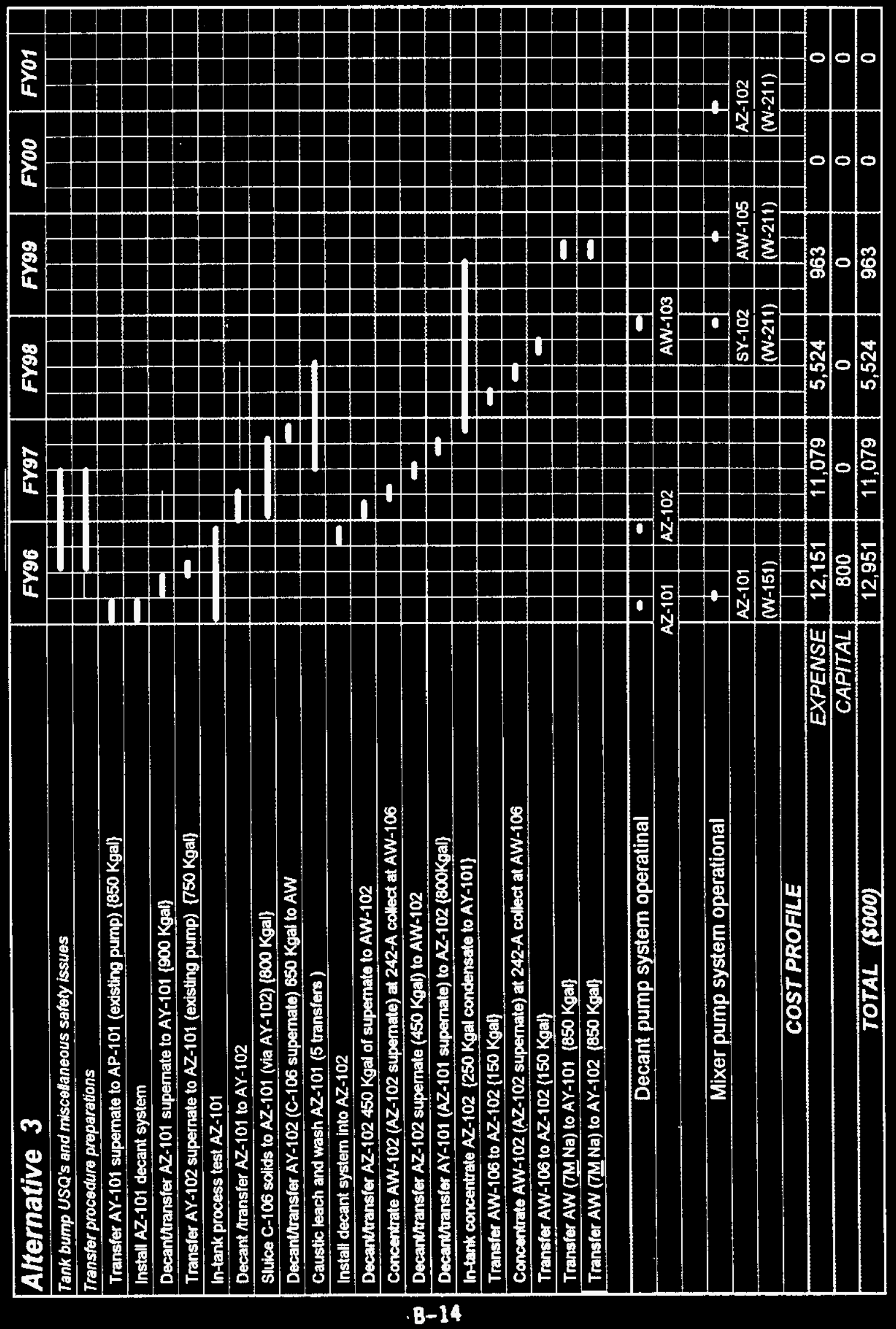




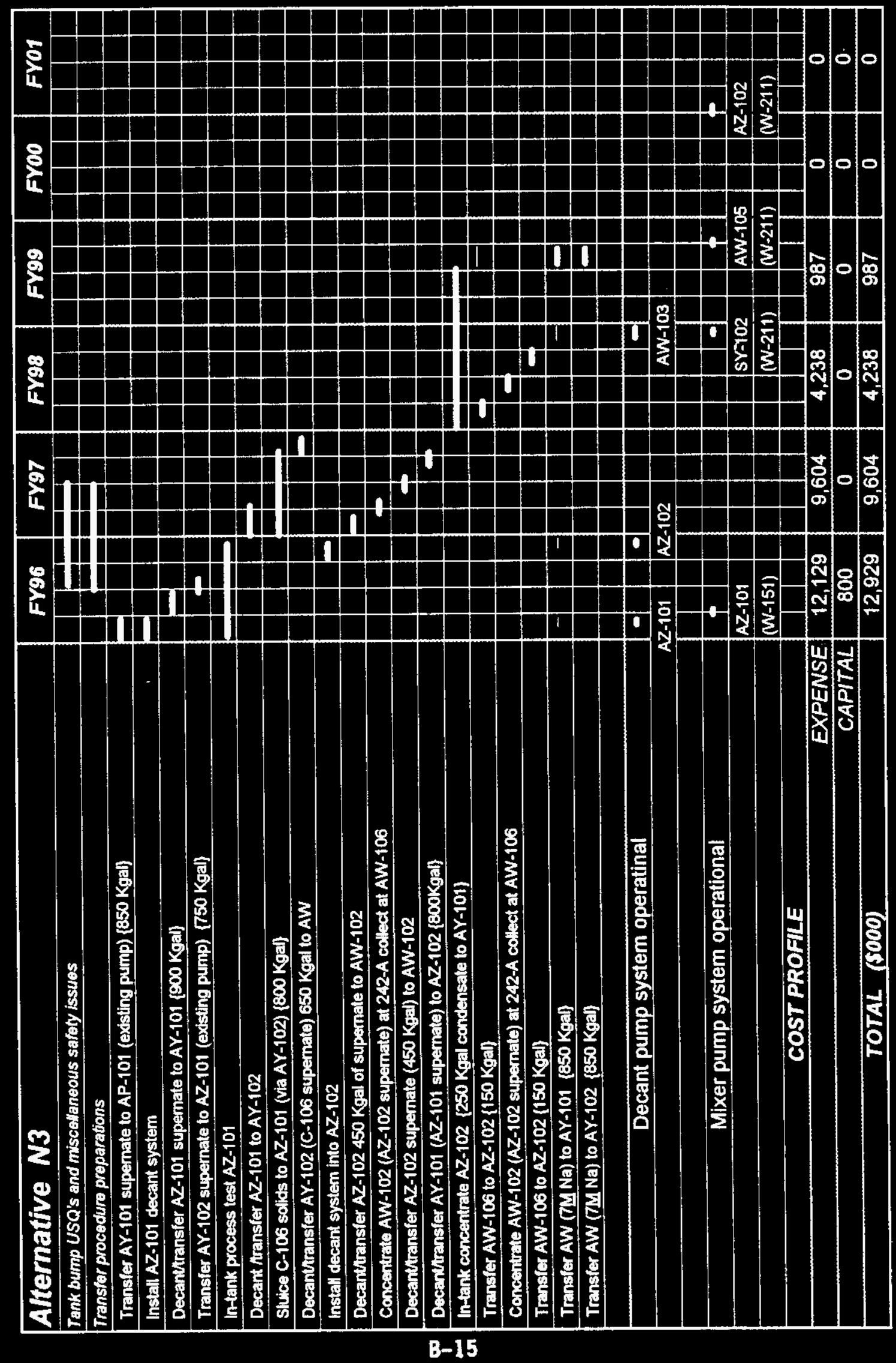


$\cdot 9 I-9$

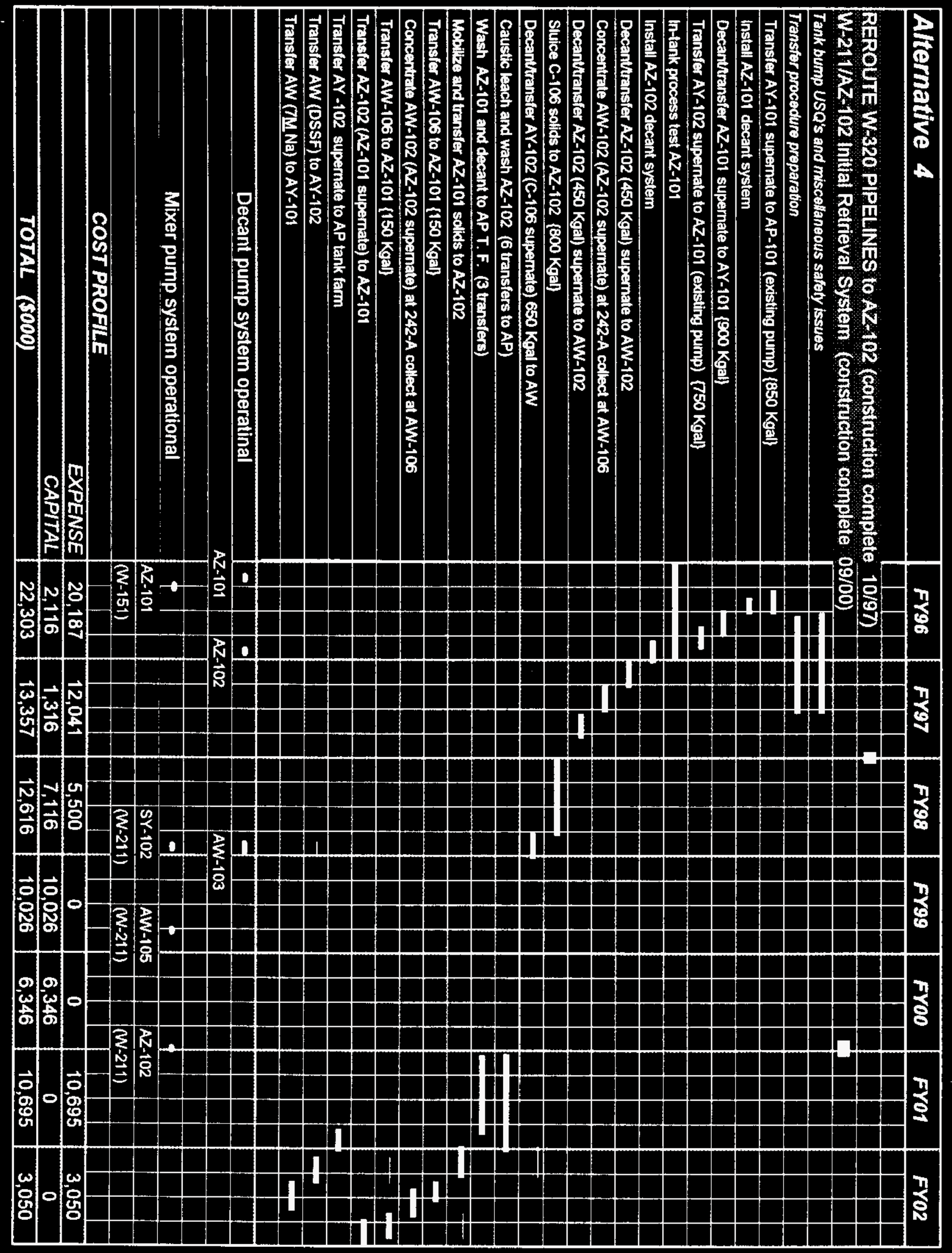




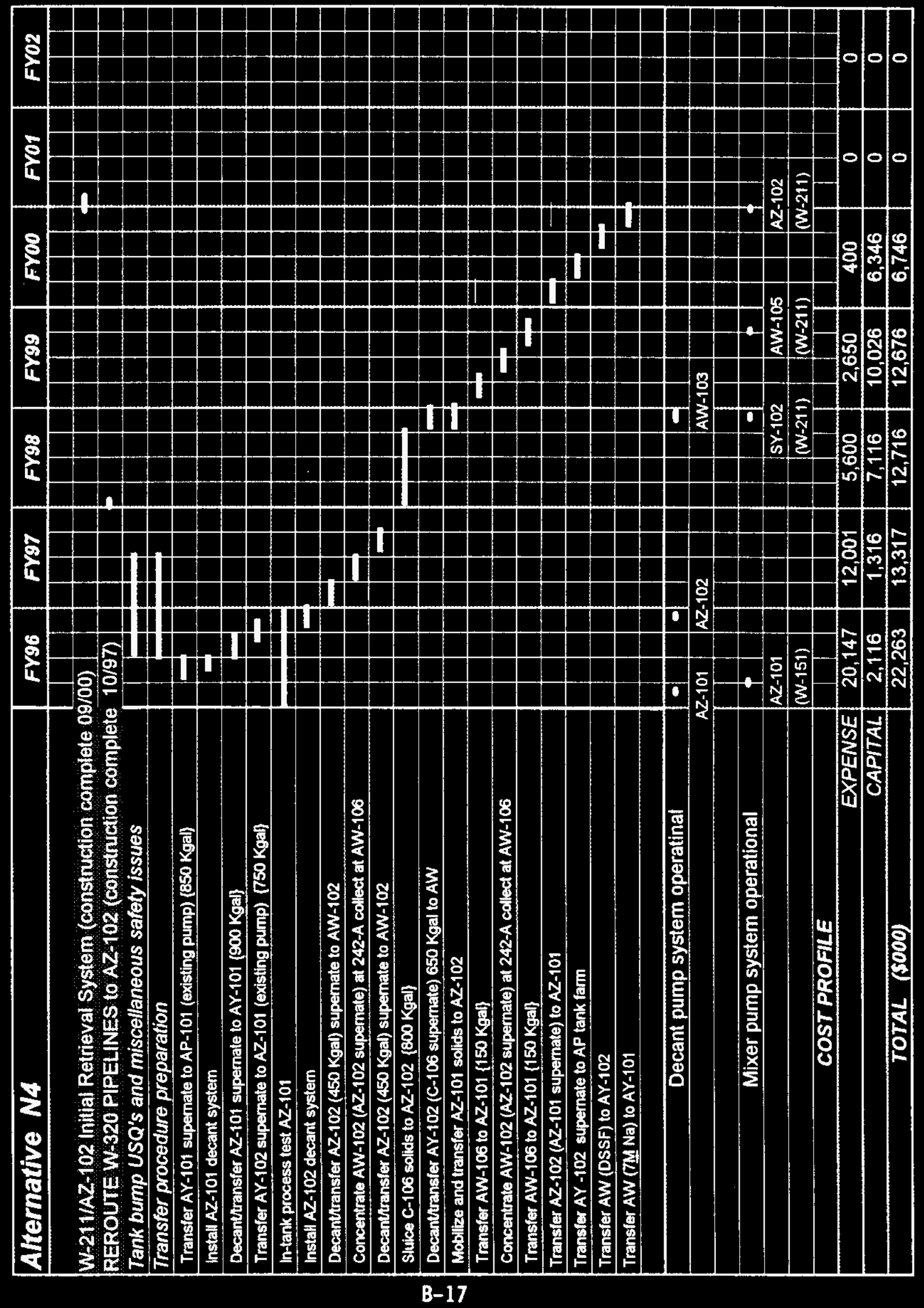




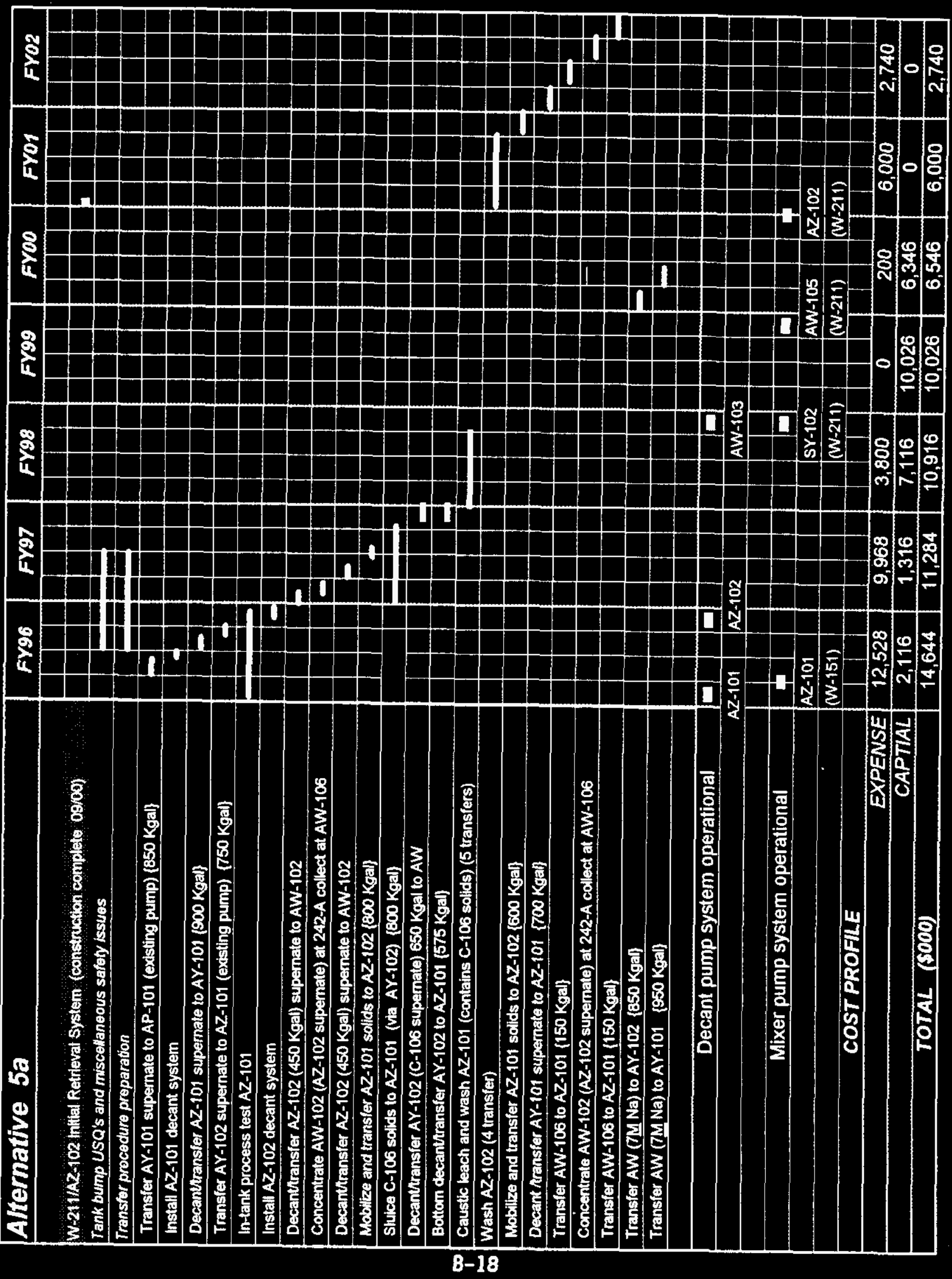




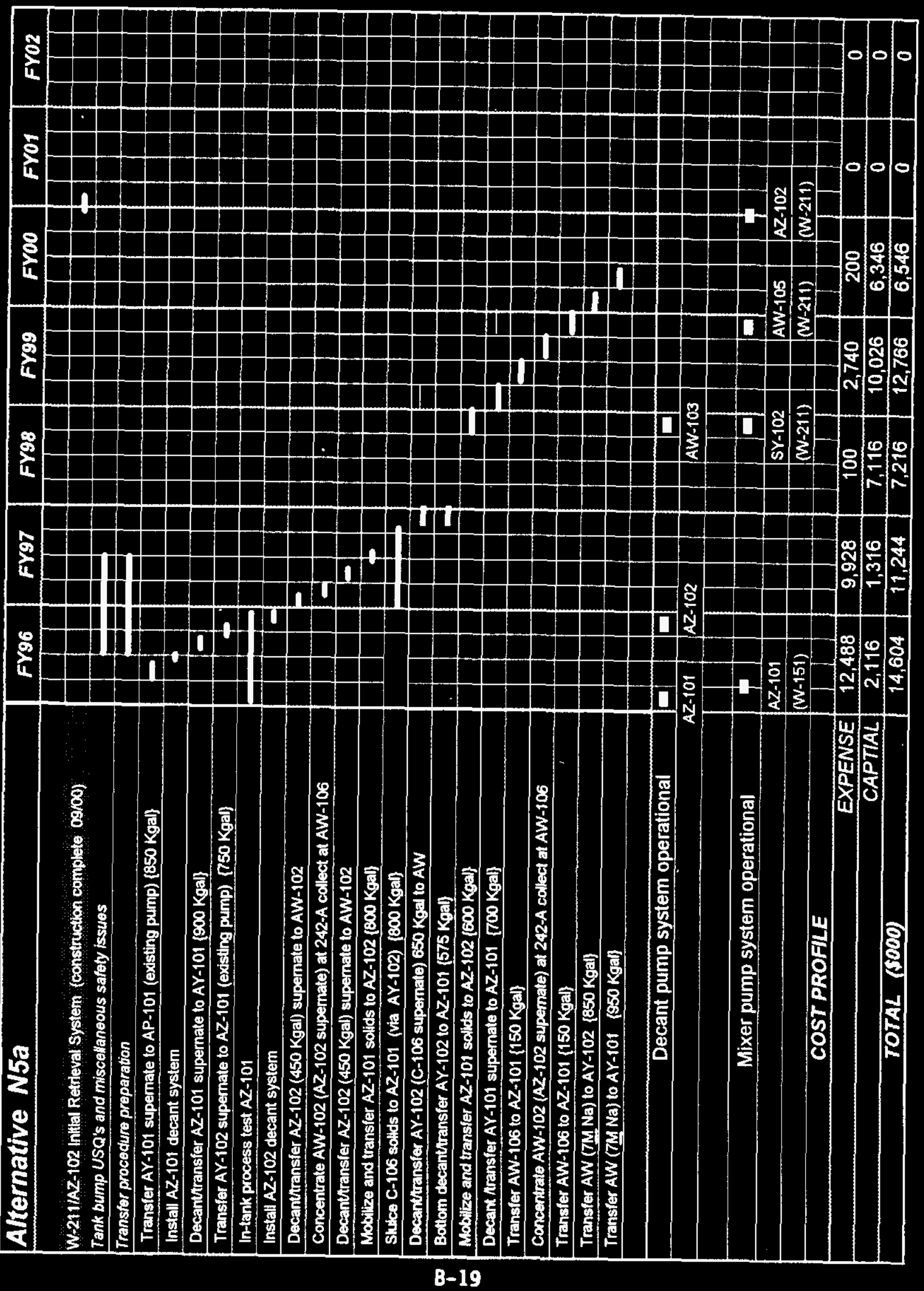




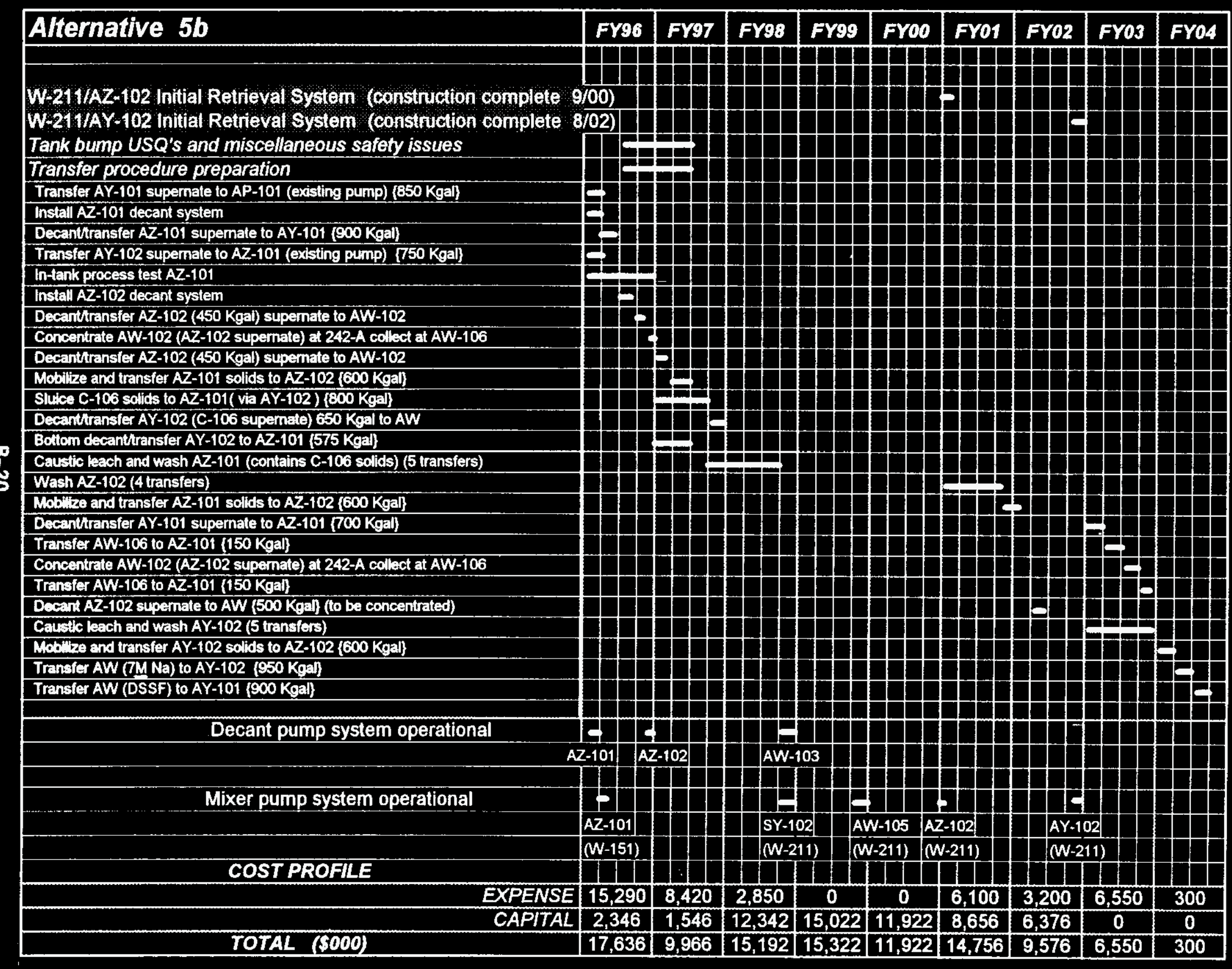




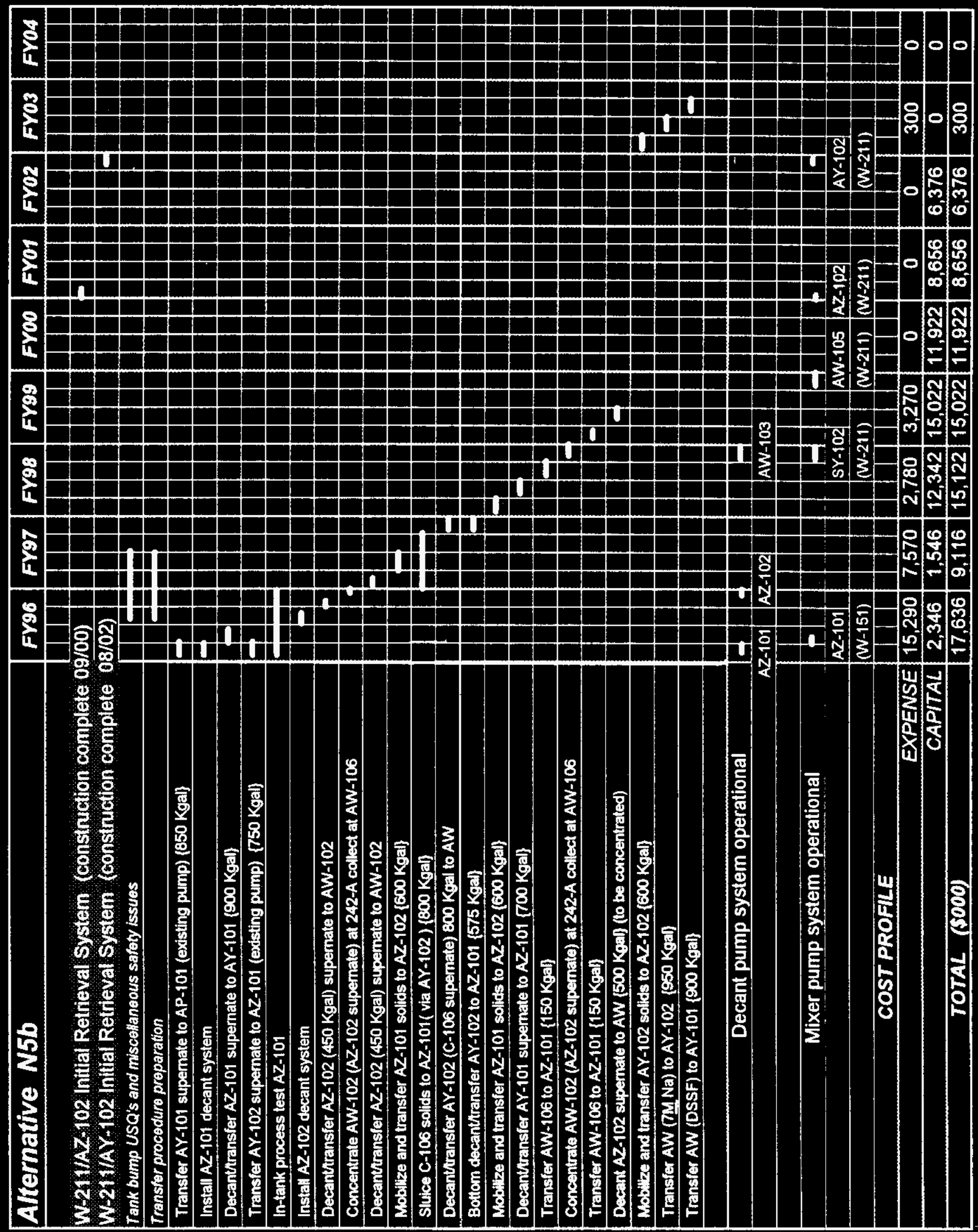




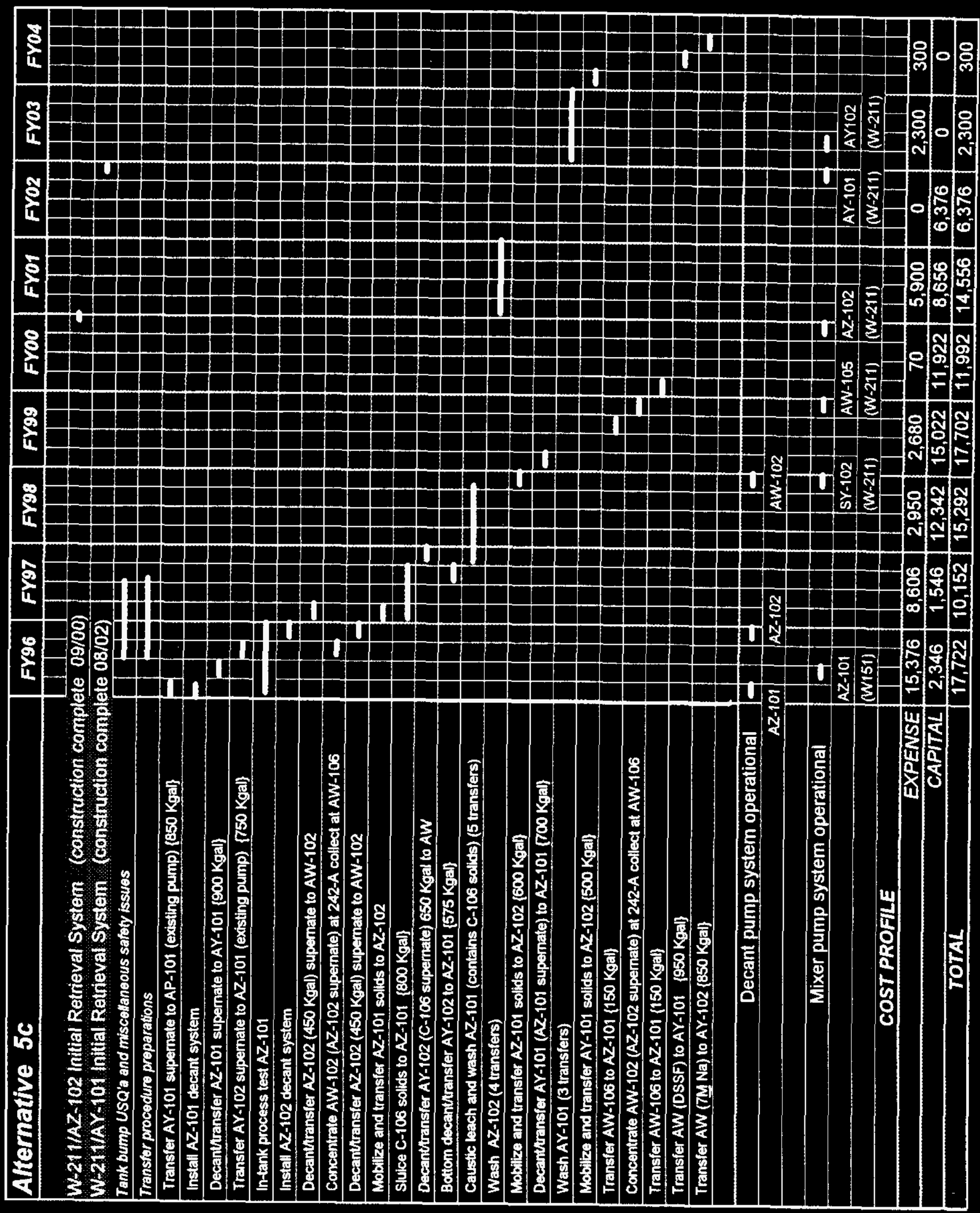




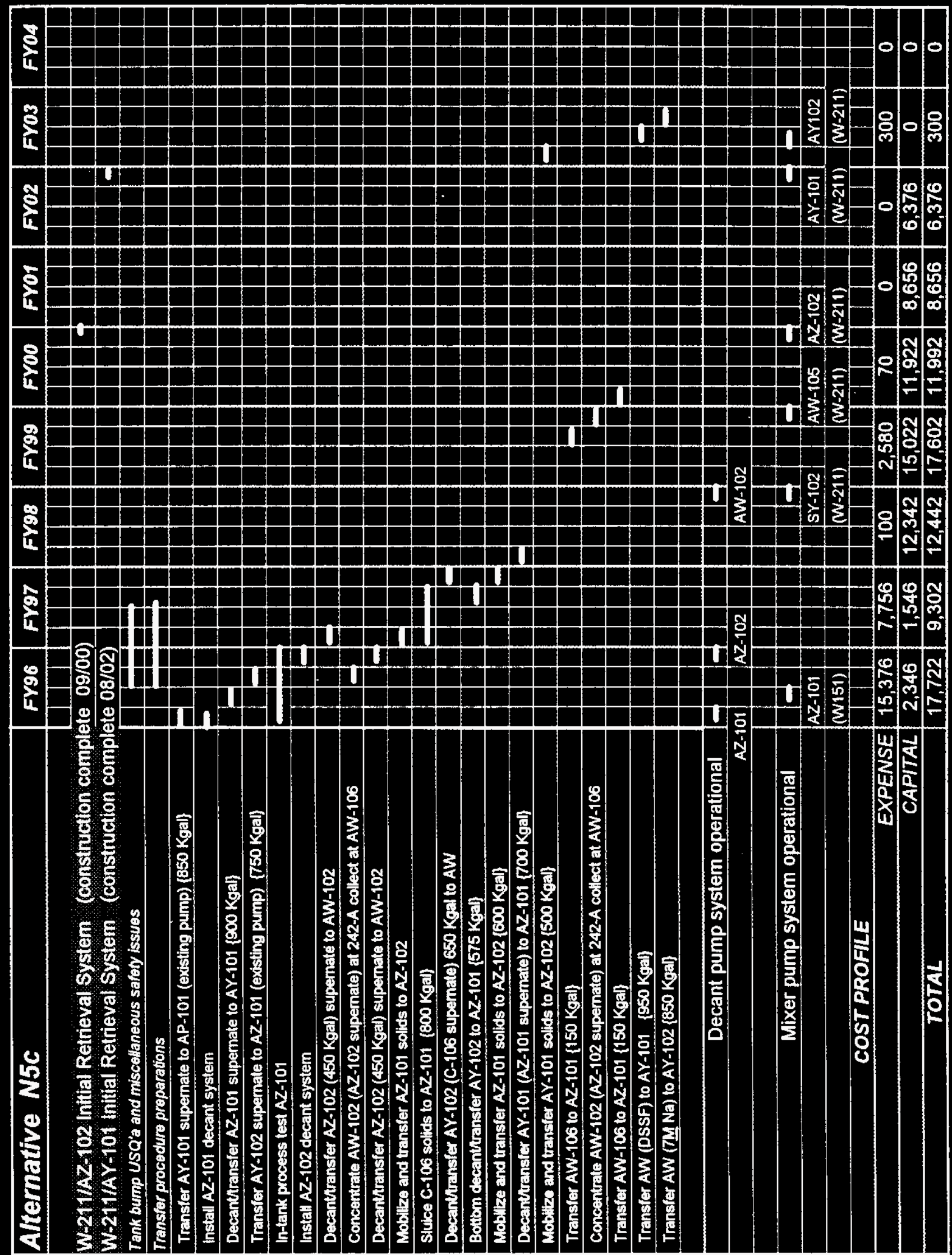




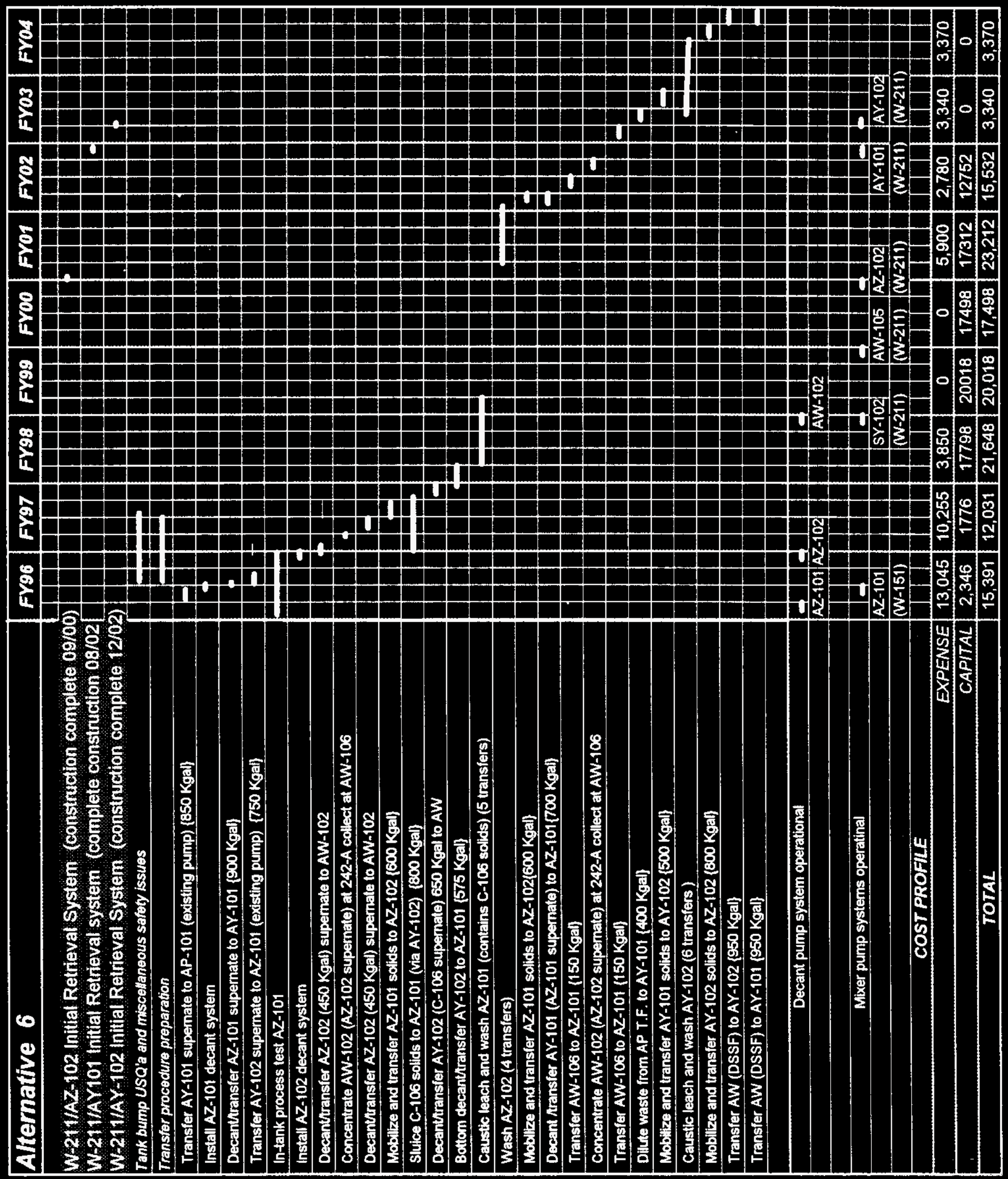


WHC-SD-WM-ER-532

Revision 0

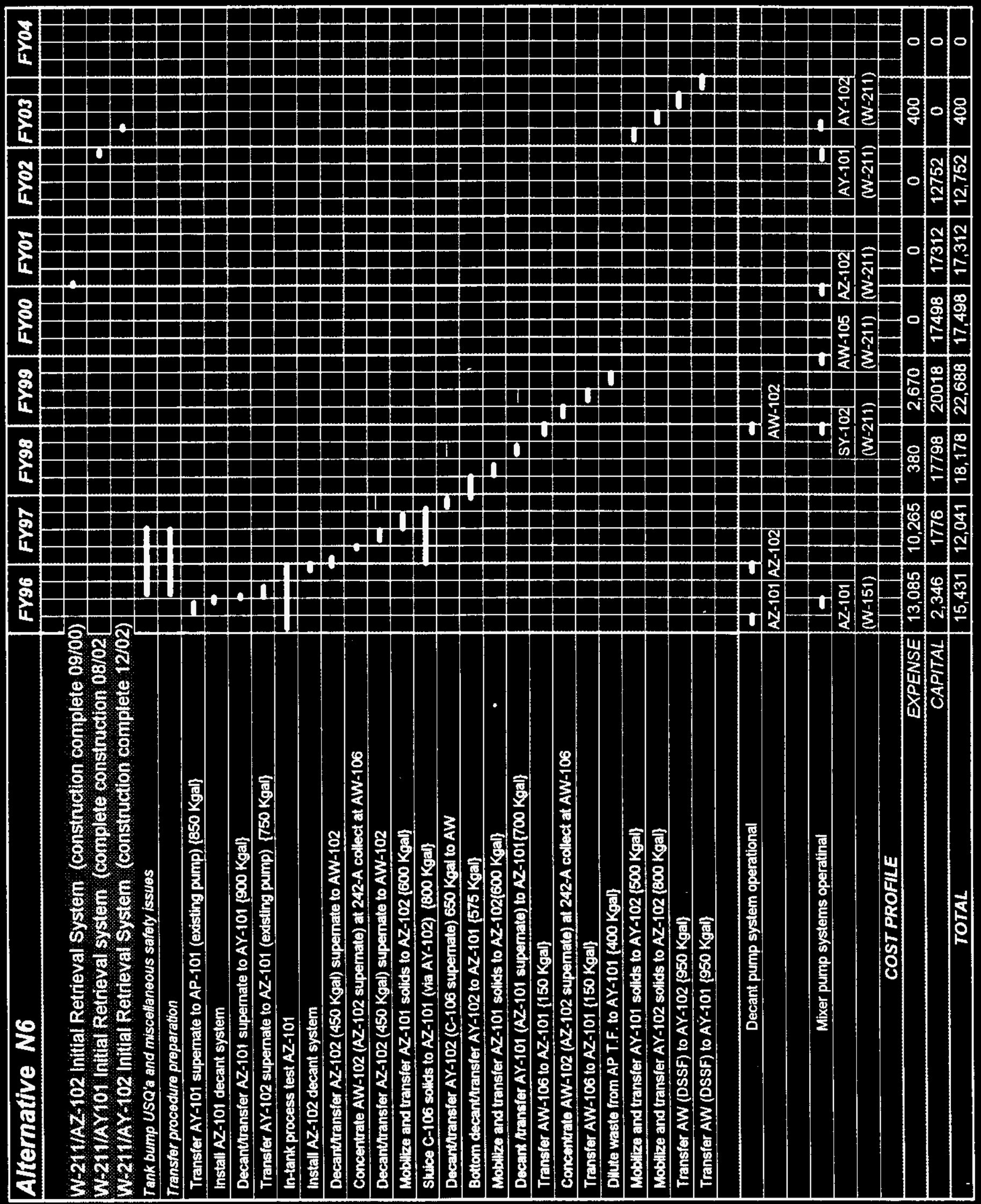




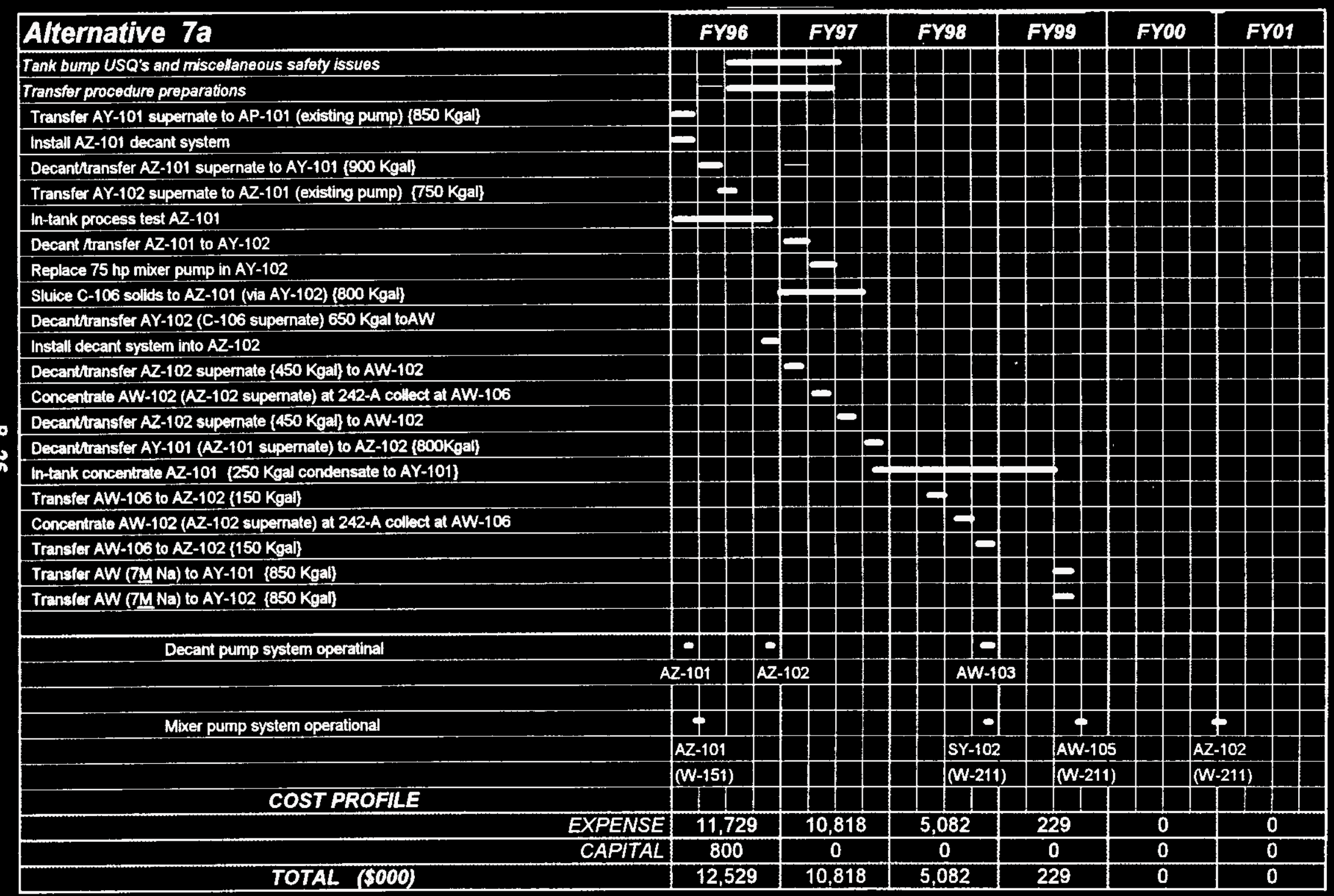




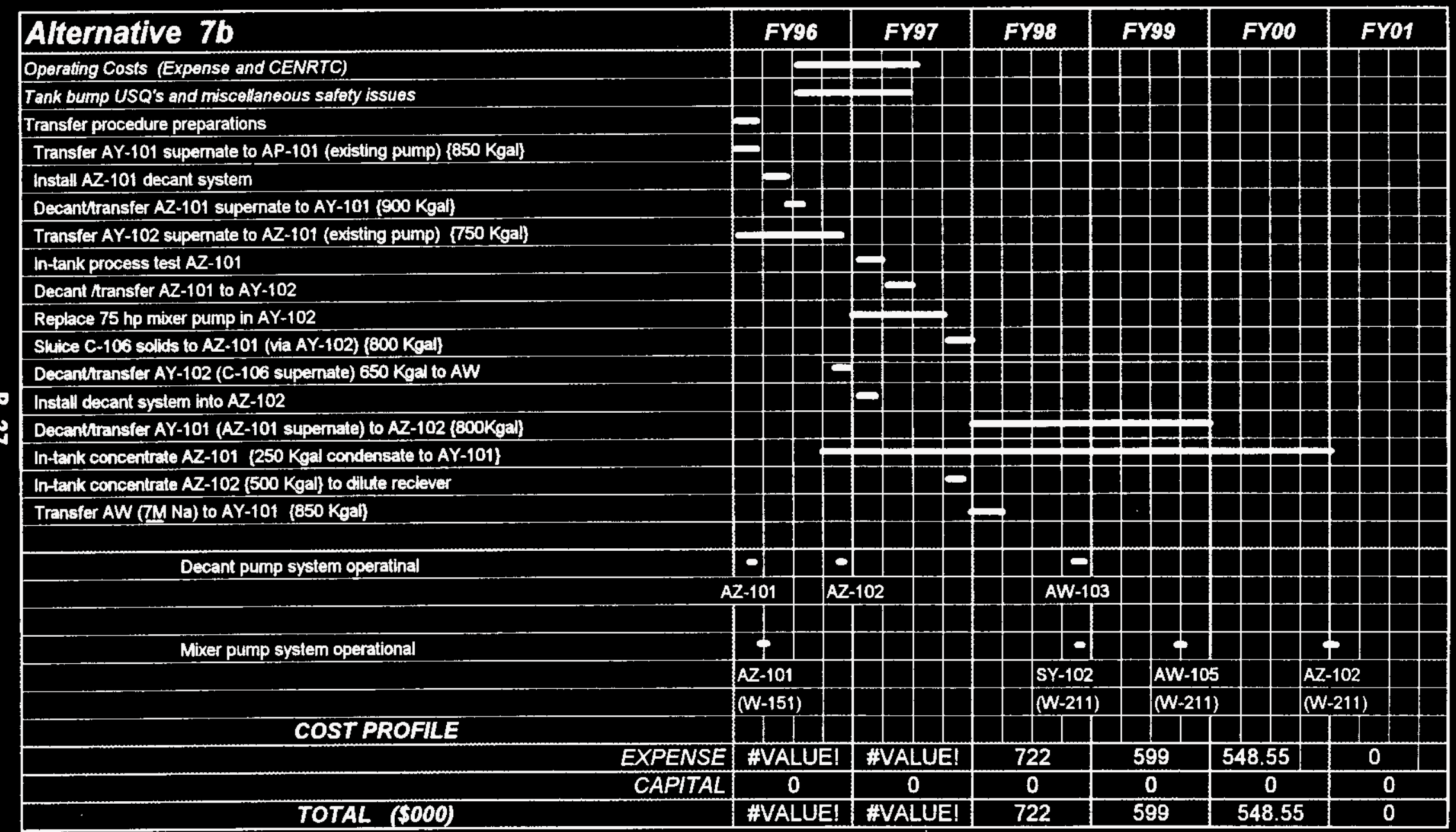


WHC-SD-WM-ER-532

Revision 0

This page intentionally left blank. 
WHC-SD-WM-ER-532

Revision 0

APPENDIX C

SCALE EVALUATIOAS

C-1 
WHC-SD-WM-ER-532

Revision 0

This page intentionally left blank. 
WHC-SD-WM-ER-532

Revision 0

APPENDIX C

SCALE EVALUATIONS

\section{Input Data to Analysis}

A computer program called Logical Decisions (Logical Decisions is a trademark of Logical Decisions) was used to calculate relationships, and develop charts, figures, and tables. The inputs were made by Excel ${ }^{*}$ spreadsheet and used the team-evaluated input. Table 3-3 in the main text is a listing of the program input. The alternatives are listed on the left, and the decision criteria are listed along the top. Individual scores for each alternative also are 1 isted.

\section{Scale Evaluations and Assumptions}

The following evaluations give the assumptions and reasoning behind each decision criteria evaluation.

\section{Personnel Risk Radiation Exposure}

Enabling assumptions used to determine the expected radiation exposures for each alternative are as follows.

Radiation exposure is expected to occur when changing or installing jumpers, installing mixer systems, and taking grab samples. A mixer system will be required whenever solids are to be transferred or washed. One rigid jumper will be installed with the installation of each pump. The exposure from installing jumpers required for mixer systems is considered to be included in the exposure from installing the mixer system. No information was available for the radiation exposure expected from changing out the jumpers in the 241-AN valve pits. Therefore, an average of the exposures from the 241-A, 241-AX, and 241-AW valve pits was used.

One grab sample is required for each transfer. The sample will be taken in the tank from which the waste is being transferred, before the transfer. No information was available for the radiation exposure expected when taking grab samples from the AW Tank Farm, so a conservative estimate of 85 mrem was used.

Exposure from installing and removing pumps was calculated using the information contained in the cc:Mail message generated by David Bullock, West Tank Farm Rad Control, to J. W. Lentsch for the calculated dose to remove

"Excel is a trademark of Microsoft Corporation.

"cc:Mail is a trademark of cc:Mail, Inc. 
the pump that is in 101-SY (November 10, 1995). T. R. Benegas estimates that 200 mrem total dose was expanded when the pump was inserted. This cc:Mail message is 1 isted below.

\section{Pump Exposure Evaluation:}

Pump pu11:

Crane operator

Person in charge tent (4 people) $0.260 *$

Install tent (3 people)

0.051

Digital acquisition control system trailer ( 3 people)

2 nuclear power operators to close receiver

3 line handlers

2 roving health physics technicians (HPT)

TOTAL person rem

0.045

0.024

0.064

0.060

0.650

*NOTE: No shielding has been added for the crane operators. It is hoped their exposure will be reduced by one-half. Also, it is desirable to put up a shield wall in front of the person in charge tent and/or 1 imit the number of people in it.

Column cutoff:
Welder
0.030
Boilermakers
0.146
Riggers (2)
0.046
HPT
0.020
TOTAL person rem
0.242

Shot loading--Steel shot, 5 minutes to fill per section; 1 minute to reposition trailer.

$\begin{array}{ll}\text { Operator on platform } & 0.151 * \\ \text { Rigger on platform } & 0.127^{\star} \\ \text { Crane operator } & 0.014 \\ \text { Fork-1 ift operator } & 0.005 \\ \text { Truck driver } & 0.007 \\ \text { HPT } & 0.030 \\ \text { TOTAL person rem } & 0.333\end{array}$

*NOTE: A determination is being made regarding the possible dose savings resulting from placing as much lead on the platform as it can handle without modification. 
Shot loading--Lead shot, 5 minutes to fill per section; 1 minute to reposition trailer.

$\begin{array}{ll}\text { Operator on platform } & 0.051 \\ \text { Rigger on platform } & 0.030 \\ \text { Crane operator } & 0.018 \\ \text { Fork1 ift operator } & 0.005 \\ \text { Truck driver } & 0.010 \\ \text { HPT } & 0.030 \\ \text { TOTAL person rem } & 0.114 \\ & \\ \text { GRAND TOTAL } & \\ \text { Pump pul1 } & 0.650 \\ \text { Column cutoff } & 0.242 \\ \text { Shot loading (stee1) } & 0.333 \\ \text { Shot loading (lead) } & 0.144 \\ \text { TOTAL person rem } & 1.225\end{array}$

\section{PERSOLNEL RADTATIOA EXPOSURE ASSUMPTIOHS}

\section{GRAB WD CORE SAMPLINS}

Personnel radiation exposures were est imated from typical radiation work permits (RWP) for grab and core sampling. An Operations crew is assigned for each operator. The calculated dose received by Operations personnel was determined from the radiation fields stated on the RWP multiplied by the average time required to take either a grab sample or a core sample, and the number of Operations personnel involved in the activity.

\section{BACKEROUNA RADIATION LEVELS}

Background radiation levels were taken from representative surveys. The survey report numbers are as follows:

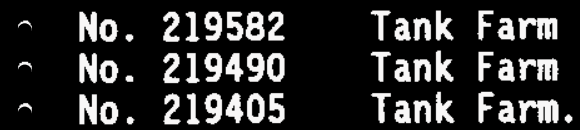

\section{Hixer-Punp Removal}

Radiation exposure 1 imits for mixer-pump removal were based on operations judgement and experience for that type of activity.

\section{Three-lar Jumper changeout}

Radiation exposure 1 imits for jumper changeout were based on operations judgement and experience for that type of activity. The following personnel are involved in a typical jumper changeout:

1 Rigger

1 HPT

1 Pipefitter 
- 1 Quality control (QC) inspector

- 4 Nuclear power operators

- 1 Electrician.

A typical jumper changeout will take 2 hours to complete. It was assumed that the operators, the HPT, and the pipefitter would be involved during the entire 2 hours. The rigger and $Q C$ inspector will be involved for 15 minutes. The electrician will be involved for 1 hour. The exposure was computed from radiological survey reports for valve pits without cover blocks installed.

The dose rates were deemed typical of what may be expected from the actual pit conditions. These numbers were added to yield total personnel exposure. The data in Table $\mathrm{C}-1$ were used in the calculations.

Table C-1. Operational Exposure.

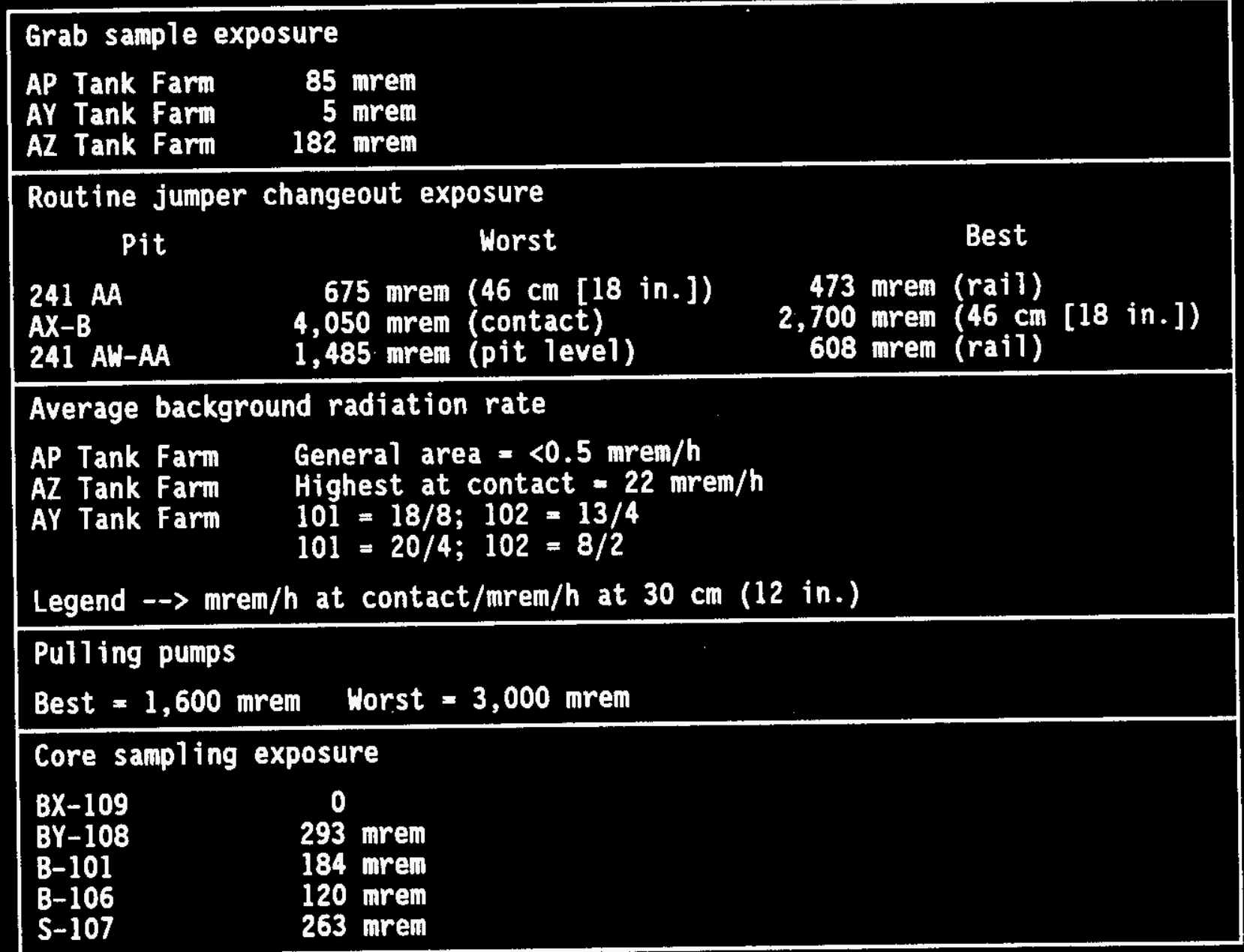

\section{OFFSITE PERSOWNEL RISK}

It was desirable to quantify offsite personnel risk to scale it against the alternatives. The accident scenario of leaks developing in new julaper connections was chosen as the most likely development to effect offsite receptors when transferring aging waste supernate and solids. 
WHC-SD-WM-ER-532

Revision 0

It was envisioned that the large supernate source term in aging waste tanks would cause significant effects offsite if the following scenario occurred. The cover blocks were inadvertently left off a diversion box or valve pit during installation of jumpers (NOTE: administrative operational safety requirements exist to prevent cover blocks from being left off). The high-curie content supernate in AZ-101 or AZ-102 is transferred to another tank but the newly installed jumpers develop one or more spray leaks. These spray leaks continue overnight until they are detected during the day or a leak detector trips and shuts down the transfer.

Similar spray release accidents were evaluated in WHC-SD-WM-SAR-065, Oraft - Tank Farn Accelerated Safety Analysis, Section 3.4.2.3.2, "Spray Release from Waste Transfer System" (WHC 1995a). Spray release accidents resulted in unacceptable risks for onsite personnel when cover blocks were not in place. Radiological dose consequences to offsite personnel met risk acceptance guidelines, but it was unclear if the evaluation used AZ-101 or AZ-102 source terms. Therefore, the spray release accident scenario was chosen as the closest incident to being a significant offsite event that was available.

The following assumptions were make to scale offsite personnel risk.

- The number of jumper changes made are directly proportional to offsite personnel risk. The more jumper changes, the more potential chances for gasket failure, or misalignment of jumpers, causing spray releases.

- The more jumper changes, the greater the chances of leaving the cover blocks off the transfer box, which allows the leak source term to become airborne.

- One transfer box entry equaled one event, even if more than one jumper was installed. It did not matter if the jumper(s) installed had three or more connections; it was one event.

\section{TALK BUIPS}

The Aging-Waste Safety Analysis Report, WHC-SD-HS-SAR-010 (Squires 1991), describes "bumping" as the "sudden release of latent heat energy which had been contained in the radioactive liquid waste." When a tank bumps, the following events are likely to occur.

- The tank pressurizes above 0.7 psig and steam is exhausted from the tank through the available openings.

- The area surrounding the tank becomes contaminated.

The safety analysis report continues, analyzing the accident as "acceptable" with a hazard level of moderate to high. 
WHC-SD-WH-ER-532

Revision 0

\section{Scales}

This safety scenario was chosen to be evaluated because consolidation of waste will tend to promote the conditions that cause tank bumps: increased heat and sludge levels. When sludge levels get too high (about $76 \mathrm{~cm}$ [30 in.]) the airl ift circulators become inoperable. Figure 3-3 in the main text shows the scale and the limits of the evaluations. Existing limits of $102 \mathrm{~cm}$ (40 in.) of sludge and $302 \mathrm{KBtu}$ are listed on the sheets as the right lower aging waste tank 1 imit. Proposed Project $\mathrm{W}-3201$ imits are 1 isted as $140 \mathrm{~cm}$ (55 in.) of sludge and about $140 \mathrm{KBtu} / \mathrm{h}$ heat load. A line was drawn between these two points to indicate the slope of an approximately equal point on the right and left sides of the diagonal center of the figure. Then the lowest point of the alternatives analyzed (Alternative 3--leached) of $76 \mathrm{~cm}$ (30 in.) and $230 \mathrm{KBtu} / \mathrm{h}$ was given a value of 100 . The highest point analyzed (Alternative 6--unleached) of $394 \mathrm{~cm}$ (155 in.) and $510 \mathrm{KBtu} / \mathrm{h}$ was given a score of 0 . A linear scale was set up as shown in Figure 3-3 to determine the possibility of a tank bump.

\section{History of Tank Bumps}

Tank bumping in aging waste tanks was first observed in the $S$ Tank farm in the 200 West Area. Before 1952, the heat content in aging waste tanks was dissipated to the ground without creating a boiling temperature in any tank. Measurable pressure variations were first observed in tank 104-S in 1953 which also coincided with temporary increases in condensate from the condensers. The pressure variations were small at first but increased in intensity and duration as the heat and sludge content of the aging waste tanks were increased.

The documented information of tank bumps suggests that all the following conditions are necessary for a tank bump to occur.

- The tank contains aging waste and is boiling.

- Heat generation of the aging waste is $>1 \mathrm{million} 8 \mathrm{tu} / \mathrm{h}$.

- The airlift circulator(s) must be off, allowing the sludge to accumulate stored energy.

The tank sludge temperature is $116^{\circ} \mathrm{C}\left(240^{\circ} \mathrm{F}\right)$.

For more history on tank bumps, see WHC-SD-WM-TA-021 (Bendixsen 1990) or WHC-SD-WH-TI-406 (Jo 1991).

\section{Draft Interia Operational Safety Requirenent (IOSR) Limits}

Draft IOSRs (WHC 1995b) are as follows. They are derived from the accelerated safety analysis (WHC 1995a), and the sections in which they are found are referenced. 
WHC-SD-WH-ER-532

Revision 0

The following are limits on aging waste tanks:

- Tank bump - 3.4.2.1.7

- Temperatures - Limiting conditions for operation - 1.3.2.1

- Must be $17^{\circ} \mathrm{C}\left(30^{\circ} \mathrm{F}\right)$ below the local boiling point

$--\quad$ sludge, $\leq 110^{\circ} \mathrm{C}\left(230^{\circ} \mathrm{F}\right)$

-- liquids $\leq 93^{\circ} \mathrm{C}\left(199^{\circ} \mathrm{F}\right)$

- Solids depth

- $\leq 102 \mathrm{~cm}$ (40 in.)

- Heat load

- Total heat load $\leq 302,641 \mathrm{Btu} / \mathrm{h}, \mathrm{AC} 5.13$

- Sludge temperature distribution

- Sludge shall $\leq 20 \mathrm{~m}^{3}\left(706 \mathrm{ft}^{3}\right)$ (about $18,900 \mathrm{~L}$ [5,000 gal]) at the thermodynamic saturation temperature (about $110{ }^{\circ} \mathrm{C}$ $\left.\left[230^{\circ} \mathrm{F}\right]\right)$, AC 5.16

- Total organic carbon (TOC) limits:

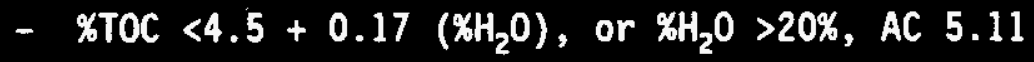

Other unresolved safety question (USQ) requirements and evaluations are listed in Appendixes $A$ and $C$, under USQ scales.

\section{Maste Compatibility}

Major and Minor USQs

The following definitions of major and minor USQs were used to specify the number of each in the evaluation.

- A major USQ evaluation requires at least one significant technical evaluation, including calculations, to resolve. It probably has a "yes" answer to one of the eight questions on the USQ form. This issue will be somewhat difficult to resolve and may not be resolvable as desired.

- A minor USQ evaluation is one that does not require a significant technical evaluation. It probably does not involve a "yes" answer to any of the questions on the USQ form. This issue will be relatively easy to resolve.

The scale chosen was linear, starting at the 0-equaling minimum amount of USQ for Alternative $0 \mathrm{a}$, and increasing to the maximum for Alternative 6. 
The USQ analysis is listed in Appendix A and was taken from the following operating specification documentation, IOSRs, etc.

WHC-SD-WM-0SR-018, Tank Farms Interim Operational Safety Requirements (WHC 1995b)
2.1 No SLs or LCSs

3.0 Limiting Conditions for Operations

3.1.1 ANF/OST Primary Tank Maximum WASTE Level

3.1.2 SST Maximum Waste Level

3.2.1 ANF Maximum WASTE Temperature

A Sludge $\leq 110^{\circ} \mathrm{C}\left(230^{\circ} \mathrm{F}\right)$

- Liquid $\leq 93{ }^{\circ} \mathrm{C}$ ( $\left(199^{\circ} \mathrm{F}\right)$

3.2.2 SST Maximum SLUDGE Temperature

3.2.3 DST Maximum WASTE Temperature

3.3.1 AMF/DST Minimum Vapor Space Pressure

3.3.2 SST Minimum Vapor Space Pressure

5.0 Administrative Controls

5.6 Organization

5.7 Procedures

5.8 Nuclear Criticality Safety

5.9 Source Inventory Control

5.10 Flammable Gas

Ventilation operable

5.11 WASTE Tank Organic Safety

A \%TOC, $4.5+0.17\left(\%_{2} \mathrm{O}\right)$, or

a $\mathrm{KH}_{2} \mathrm{O}>20$

5.12 Requirement for Dome Load

5.13 Requirement for Heat Load

- $\leq 88,695 \mathrm{~W}$ radiolytic and equipment

5.14 Requirement for Concrete Temperature Variance

For ANF tank, maximum of $19.4^{\circ} \mathrm{C} /$ day $\left(35^{\circ} \mathrm{F} /\right.$ day $)$

5.15 Requirement for WASTE Sol ids

< < $\mathrm{m}(3 \mathrm{ft}$ )

5.16 Requirement for SLUDGE Temperature Distribution

5.17 Requirement for Transfer System Covers
$520 \mathrm{~m}^{3}\left(215 \mathrm{ft}^{3}\right)$ at thermodynamic sat

5.19 Requirement for Transfer Line Leakage

5.20 Requirement for Exhaust Filtration

OSR-T-152-00002, Rev/Mod A-1 (WHC-SD-HS-SAR-010, Rev. 2 [Squires 1991]), Aging-Waste Facility Operational Safety Requirenents, March 8, 1989.

11.4 Primary Vessel Hydrostatic Head $\geq-3$ inches w.g.

11.5 Air-Lift Circulator Operation (Tank Bump)

11.6 Primary Tank Leak Detection

11.7 Tank Pressurization

11.8 Waste Transfer Leak Detection 
WHC-SD-WM-ER-532

Revision 0

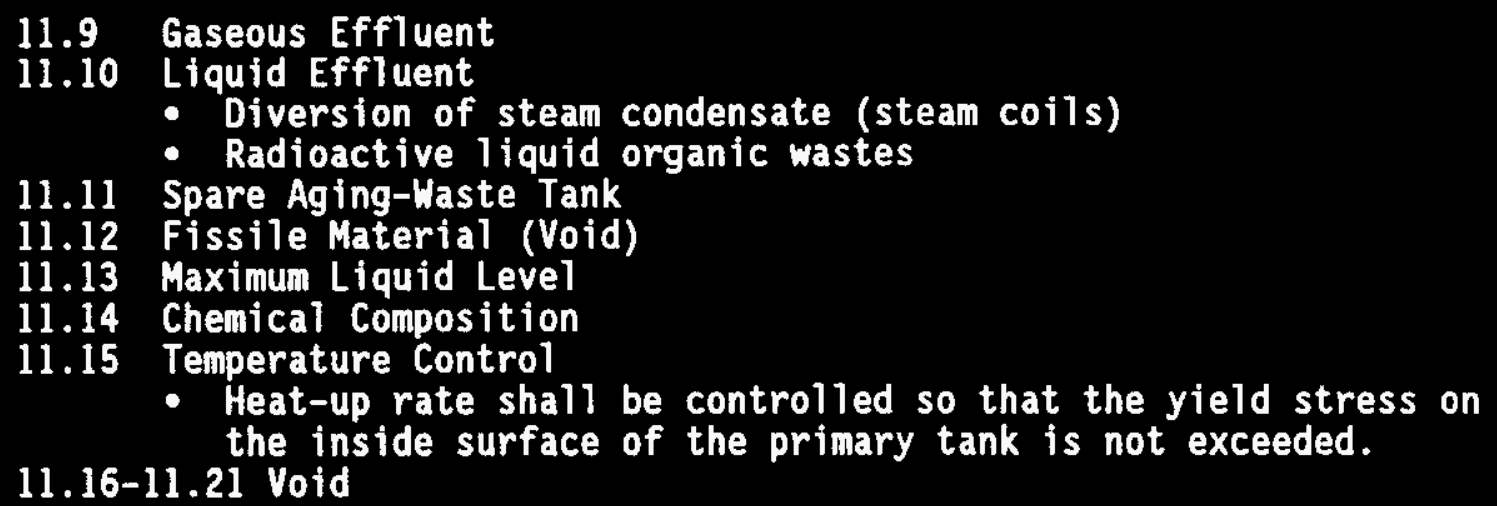

OSD-T-151-00017, Rev D-6, Operating Specifications for Aging-Waste Operations in 241-AY and 241-AZ (Bergmann 1994).

17.2 Underground Aging-Waste Storage Tank Operations

17.2.1 Liquid Levels

17.2.2 Primary Tank Leak Detection

17.2.3 Hydrostatic Head

17.2.4 Dome Loading

17.2.5 Live Loads

17.2.6 Primary Tank Temperature

17.2.7 Concrete Temperature

17.3 Aging-Waste Transfer Operations

17.3.1 Waste Transfer Leak Detection

17.3.2 Composition of Transferred Waste

- Pu $\leq 200 \mathrm{~g} / \mathrm{batch}$

- $P u \leq 0.05 \mathrm{~g} / \mathrm{gal}$

- For $\mathrm{Pu}>15 \mathrm{~g}$, air-1ift circulator of slurry distributor operating

17.3.3 90-day rule

- For $>1,000$ MTU of waste and $>48 \mathrm{~cm}$ (19 in.) sludge, the maximum time between transfers is 90 days

17.4 Aging-Waste Storage Operations

17.4.1 Waste Composition

17.4.1.1 Chemical Composition

17.4.1.1.1 Criticality Prevention

- Total Pu/tank $<50 \mathrm{~kg}$

- Pu $\leq 1 \mathrm{~g} / \mathrm{L}$

17.4.1.1.2 5N Na Rule

- $\quad 55.5 \mathrm{M} \mathrm{Na}$ in 101-AZ

- $\leq 5.0 \mathrm{~K} \mathrm{Na}$ in other aging waste tanks

17.4.1.1.3 Hydroxide

- $\geq 0.01 \mathrm{~N}$ for $\mathrm{NO}_{3}<1 \mathrm{molar}$

- $\geq 0.84$ for $\mathrm{NO}_{3}<3$ molar

- 21.0 .4 for $\mathrm{NO}_{2}+\mathrm{NO}_{3}>5.5$ molar

17.4.1.1.4 Corrosion Control 
WHC-SD-WM-ER-532

Revision 0

\subsubsection{In-Tank Solids}

- For solids $>27 \mathrm{~cm}$ (10.7 in.), temperature of

17.4.2 Steam Condensate solids $\leq 1814.1 / H_{s}+110{ }^{\circ} \mathrm{C}\left(230{ }^{\circ} \mathrm{F}\right)$

17.4.3 Liquid Organic Waste

17.4.4 Heat Content

- Maximum heat content for AWF $=4 \mathrm{million} B t u / h$

17.4.5 Waste Temperatures

For solution temperatures $<52{ }^{\circ} \mathrm{C}\left(125{ }^{\circ} \mathrm{F}\right)<5.6{ }^{\circ} \mathrm{C} /$ day $\left(10^{\circ} \mathrm{F} / \mathrm{day}\right)$

- For solution temperatures $>52{ }^{\circ} \mathrm{C}\left(125^{\circ} \mathrm{F}\right)<1.7^{\circ} \mathrm{C} /$ day $\left(3{ }^{\circ} \mathrm{F} /\right.$ day $)$ or $13.3{ }^{\circ} \mathrm{C} /$ day $\left(24^{\circ} \mathrm{F} /\right.$ day $)$ if temperature is kept constant within $1.7^{\circ} \mathrm{C}\left(3^{\circ} \mathrm{F}\right)$ for 8 days thereafter

17.4.6 Air-lift Circulator Operation

- Minimum of $50 \mathrm{cfm}$ for waste temperature $>93{ }^{\circ} \mathrm{C}$ $\left(200^{\circ} \mathrm{F}\right)$

17.4.7 Vapor Space Pressure

17.4.8 Spare Aging-Waste Tank

17.4.9 Total Fuel Concentration

$480 \mathrm{~J} / \mathrm{g}$

17.4.10 Ferrocyanide

- Cyanide max. 3.9 Wt\%

17.4.11 Organic Salts

- TOC $\leq 3$ wt\% (dry basis)

17.4.12 Toxic Vapor

< <IDLH

17.4.13 Flammable Gases

- $\leq 20 \%$ LFL

\section{Criticality}

The criticality concerns of the proposed waste transfers among tanks $A Y-101, A Y-102, A Z-101$, and $A Z-102$, and the waste transfer from $C-106$ and AY-102, were reviewed.

The contents of the tanks were reviewed to determine plutonium inventories.

The existing solutions in each of the tanks contain trivial amounts of plutonium compared to the plutonium in the solids. The solutions may be used as slurry or sluicing media but will not redissolve or otherwise have a measurable effect on the redistribution or concentration of plutonium in the solids.

Measurable amounts of plutonium exist in the solids in each of the tanks. The estimated amounts of plutonium are as follows:

- AY-101 $23.35 \mathrm{~kg}$

- AY-102 $8.64 \mathrm{~kg}$ 
MHC-SD-WH-ER-532

Revision 0

- AZ-101 $19.25 \mathrm{~kg}$

- AZ-102 $27.19 \mathrm{~kg}$

- $\quad$ C-106 $97.5 \mathrm{~kg}$.

The source of the inventory estimate for C-106 is WHC-SD-SQA-CSA-20363, CSER 94-001 Criticality Safety of Single-Shell Waste Storage Tanks

(Rogers 1994). The source of the other estimates is WHC-SD-WM-TI-640, Double-She17 Tanks Plutoniun Inventory Assessinent (Tusler 1995). These estimates, which are based on the highest plutonium value in any tank sample, are considered the high estimates for the tanks. For criticality concerns, if the proposed transfers with these numbers are acceptable the actual safety margins are even greater because a conservative plutonium inventory has always been used for analyses.

\section{Tank $\mathbf{c}-106$}

Tank C-106 contains about $746,000 \mathrm{~L}(197,000 \mathrm{gal})$ of solids. The criticality implications of transferring this waste into AY-102 were analyzed in WHC-SD-SQA-CSA-20363 (Rogers 1994). "A sizeable margin of criticality safety will be maintained throughout the process of transferring waste from tank C-106 to tank AY-102. No mechanism capable of causing criticality as the result of mixing these wastes has been found."

The high estimate of plutonium in $\mathrm{C}-106$ solids is $0.127 \mathrm{~g} / \mathrm{L}$. This concentration is $<5 \%$ of the minimum required to make plutonium critical under optimum conditions. In addition, the solids contain other materials that retard criticality. The iron-to-plutonium ratio is four times as large as the subcritical limit. The manganese-to-plutonium ratio is almost three times as large as the subcritical 1 imit.

\section{Tank AY-102}

Tank AY-102 contains about $121,000 \mathrm{~L}(32,000 \mathrm{gal})$ of solids. The criticality implications of transferring C-106 waste into AY-102 were analyzed (Rogers 1994).

The high estimate of the plutonium in AY-102 solids is $0.072 \mathrm{~g} / \mathrm{L}$. This concentration is $<3 \%$ of the minimum required to make plutonium critical under optimum conditions. In addition, the solids contain other materials that retard criticality. The iron-to-plutonium ratio is 9.8 times as large as the subcritical limit. The manganese-to-plutonium ratio is 5.1 times as 1 arge as the subcritical limit. Both boron and cadmium have concentrations high enough to ensure subcriticality for the plutonium in AY-102.

A slurry distributor is used to spread the incoming slurry over the surface of the waste in AY-102. For a criticality to occur, the plutonium would have to be concentrated at a factor $>20$ while at the same time not concentrating the iron, manganese, boron, and cadmium. In addition, the presence of hydrogenous compounds, such as water, would increase the required plutonium concentration by a factor of about 3. Because of these conditions, subcriticality is not dependent on the distribution of the wastes. 
WHC-SD-WH-ER-532

Revision 0

Tank AY-101

Tank AY-101 contains about $314,000 \mathrm{~L}(83,000 \mathrm{gal})$ of solids. The high estimate of plutonium in the solids is about $0.074 \mathrm{~g} / \mathrm{L}$. This plutonium concentration in the solids is essentially the same as in AY-102.

Tank AZ-10I

Tank AZ-101 contains about $132,500 \mathrm{~L}(35,000 \mathrm{gal})$ of solids. The high estimate of plutonium in the solids is about $0.145 \mathrm{~g} / \mathrm{L}$.

Tank AZ-102

Tank AZ-102 contains about 360,000 L (95,000 gal) of solids. The high estimate of plutonium in the solids is about $0.076 \mathrm{~g} / \mathrm{L}$.

\section{Specification Reviow}

The criticality prevention specifications (Vail 1995) for double-shell tanks (DST) were reviewed. Transfers between tanks are not required to meet the solids-to-plutonium mass ratio applied to waste discharges from a generating facility. Tank waste meets the mass. ratio before the transfer and no mechanism is available during waste transfer that changes the solids to plutonium mass ratio. For transfers into tanks with batches containing $>200 \mathrm{~g}$, the solids-to-plutonium ratio must be at least 1,000 and the plutonium concentration in the incoming stream must be $<0.125 \mathrm{~g} / \mathrm{L}$. In the receiving tank, the tank-averaged solids-to-plutonium ratio for settled solids must be at least 5,000 .

The solids-to-plutonium ratio estimates for the existing tank inventories are as follows:

\begin{tabular}{|c|c|c|}
\hline Tank & $\begin{array}{c}\text { Plutonium } \\
(\mathrm{g} / \mathrm{L})\end{array}$ & Solids-to-plutonium ratio \\
\hline AY-101 & 0.074 & 16,200 \\
AY-102 & 0.072 & 16,600 \\
\hline AZ-101 & 0.145 & 8,200 \\
AZ-102 & 0.076 & 15,700 \\
\hline C-106 & 0.127 & 9,400 \\
\hline
\end{tabular}

These ratios were determined using the most conservative assumptions regarding plutonium concentration and solids density, which result in the smallest solids-to-plutonium ratio. In every estimate, the solids-to-plutonium ratio is much $>1,000$ and $>5,000$.

The plutonium concentration of an incoming stream is expected to be much $<0.125 \mathrm{~g} / \mathrm{L}$ due to the dilution of the solids during the sluicing operation. The transfer of the $C-106$ waste was analyzed (Sederburg 1994). 
WHC-SD-WM-ER-532

Revision 0

An estimate also was made to determine the effect of washing the $\mathrm{C}-106$ solids in AZ-101. As much as $40 \%$ of the solids could be removed by washing (MacLean 1995). None of the plutonium is assumed to be removed by washing. The conservatively calculated solids-to-plutonium ratio after washing is 5,755 , assuming a plutonium concentration of $0.212 \mathrm{~g} / \mathrm{L}$ and no retention of solids from the transfer of waste from $A Z-101$ to $A Z-102$.

\section{Suggested Criticality Specification Revisions}

The operating specifications also were reviewed (Bergmann 1994). As expected, these specifications are more conservative than the criticality prevention specifications. The planned consolidation operations would be affected by the criticality prevention, Section 17.4.1.1.1 of the operating specifications, which 1 imits the amount of plutonium in an aging waste tank to $50 \mathrm{~kg}$. This section would need to be changed or waived to transfer the contents of $\mathrm{C}-106$ into any aging waste tank.

In the operating specifications, Section 17.3.2 limits the composition of transferred waste. This section limits the amount of plutonium per batch to $200 \mathrm{~g}$ and a concentration of $0.012 \mathrm{~g} / \mathrm{L}$. " This section also would need to be changed or waived to transfer the contents of C-106 into any aging waste tank.

No actual criticality concerns exist for tank-to-tank transfers of waste because the minimum concentration of plutonium required to cause a criticality is $2.6 \mathrm{~g} / \mathrm{L}$ in a very large volume (Sederburg 1994). The minimum plutonium concentration that can cause a criticality in a liquid system is about $7 \mathrm{~g} / \mathrm{L}$. No known mechanism exists that is capable of approaching possible criticality through concentration of plutonium in a receiver tank.

The specification documents must be revised and approved to reflect the acceptance of the planned transfers into and within the aging waste tanks.

\section{OPERATIONAL RISK-COONPLEXITY OF OPERATIOMS}

\section{UNIT OPERATIONS}

The values for the number of unit operations for each transfer alternative were based on Section 3.5.2.2 of the main text.

\section{Transfers to Concentrate High-Heat Maste (Hajor USQ)}

For the purposes of this section, high-heat waste will be concentrated waste that is $>6 \mathrm{C} / \mathrm{gal}$. Most alternatives have transfers of AZ-102 waste that is concentrated to about $12 \mathrm{Ci} / \mathrm{gal}$ cesium-137 in the evaporator. The waste tanks and Evaporator 242-A have safety analys is report (SAR) 1 imits of $6 \mathrm{Ci} / \mathrm{gal}$. The evaporator has an accident scenario that is based on $6 \mathrm{Ci} / \mathrm{gal}$.

The evaporator accident scenario will have to be reevaluated for this unit operation to proceed. It may require moving personnel from their normal work areas, or taking special, temporary precautions when in a specific area during evaporation. Finally, the accident scenario may be unacceptable and a limit lower than $12 \mathrm{Ci} / \mathrm{gal}$ may have to be set on evaporation of the solutions at 242-A. This would mean that the solution would have to be further

$$
\text { C-15 }
$$


concentrated in aging waste tanks when available concentration has been completed in the evaporator. This is possible with the aging waste condensate existing system through the A-417 catch tank.

It is also possible to in-tank evaporate with the new $\mathrm{W}-030$ system by shutting down the condenser for the tank in question and operating the chiller at a higher capacity. Condensate collects in the 37,900-L (10,000-gal) AZ-151 catch tank and is transferred back to the aging waste tanks. (A7so see "Number of Transfers" and "Number of Decant and Supernate Transfers" following this section.) Rice (1995) estimates the condensate rate needed to accomplish in-tank evaporation at several different operating conditions. This condensation rate was used to estimate durations of evaporation needed for in-tank evaporation in Alternatives $\mathrm{Oa}$ and $\mathrm{Ob}$.

Waste transfer routes may have to have temporary warning signs installed for the two transfers that are anticipated from Evaporator 242-A receiver tank AW-106 to the aging waste tank farms. This transfer routing crosses roads that may have to be temporarily shut down. No unacceptable impacts are anticipated to the site or personnel for these two $250-\mathrm{Kgal}$ " short-term transfers. These temporary mitigation measures have been applied in previous years to transfers of aging waste solutions to B Plant.

\section{Leaching and Nashing}

The number of leaching and washes was evaluated based on the number of times that the overall operation was performed, not the number of transfers it required. There are generally two washing operations for every leaching operation. Those three operations are counted as one leach and wash.

\section{Sludge Mixing}

Solids settling was accounted for each time a solid was allowed to settle in another tank, except for the transfer of $\mathrm{C}-106$ to $\mathrm{AZ}-101$ via $\mathrm{AY}-102$. This operation did not require mixing of sludge. However, it was accounted for as two solid transfers.

\section{CUABBFR OF TRAUSFERS}

\section{Solids Transfers}

The number of solids transfers was determined to assign a scale to this type of operational risk. Slurry transfers will tend to plug 1 ines and foul pumps if not correctly performed.

\section{Decant and Transfer}

Decant and transfer scales take into account all supernate transfers. They also take into account the condensate transfers for in-tank concentration. These condensate transfers are relatively small transfers,

\footnotetext{
"See the Conversion Table in front matter of document.
} 
WHC-SD-WH-ER-532

Revision 0

about $37,900 \mathrm{~L}(10,000 \mathrm{ga} 1)$. Every five small transfers are counted as one big transfer. Decanting and transfer do not include liquid transfers from leaching and washing.

\section{OPERATIONAL RISK--TANK EOUIPAEXT MODIFICATIONS}

\section{Tank Drain Line}

When the settled sludge volume exceeded $152 \mathrm{~cm}$ (60 in.) in any tank it was counted as potential concern with plugging tank drain lines. The aging waste tanks have pit drains that extend to $152 \mathrm{~cm}(60$ in.) above the bottom of the aging waste tanks. It was thought that these drains would be plugged by settled solids above $152 \mathrm{~cm}(60 \mathrm{in}$.$) , and the drains would have to be$ modified.

\section{Process Pits Modification}

When rigid jumpers were installed or modified, the cover blocks above them would have to be modified due to the change of routing and addition of valves that invariably occur in rigid jumpers. The pit cover blocks would need to be repainted, holes drilled, and locking-valve actuator handles installed. This was considered to be part of the operational risk. The number of pits in which new jumpers were installed were determined for each alternative, and the number of pits to be modified was totaled.

\section{TECHWOLOOY RISK}

\section{Number of DST STudges to Mobilize}

The number of DST sludges being mobilized is a concern because it is not well known how much of the total sludge will mobilize when mixed with mixer pumps. Reports from the Savannah River Site and from British Nuclear Fuels Ltd., as well as one-twelfth-scale pilot plant information, indicate that sludge is different in each tank. No two patterns of sludge removal are the same. So there is a risk that too little sludge will be suspended from mixing operations, and the estimated amount of sludge cannot be washed or transferred. Therefore, every time sludge was mixed to transfer or wash it was counted as one technology risk. This scale is the same as the "Number of mixing of sludges" measure above.

\section{Bottom Decant Operation}

Bottom decant refers to the transfer of C-106 settling slurry in SY-102 to another tank by a transfer pump without additional agitation. Bottom decant has not been performed before now, so it is uncertain how well it will work. It is estimated that about 50\% of the total solids from $\mathrm{C}-106$ will be transferred to the next aging waste tank. The results of this transfer are highly, operationally specific. Changes in timing, modification of Project W-320 operations and equipment, or breakdown of equipment or/and other delays can make a large difference in the amount of solids transferred.

Therefore, the botton decant was either necessary for a successful scenario or it was not used. 
HHC-SD-WM-ER-532

Revision 0

\section{FEFD PRFPARATTOM PROCFES}

\section{Process Information}

\section{Number of DST S1udges Washed}

How well DST sludges are washed will indicate the efficiency of the process. This information can be used to determine flowsheet values and size of equipment, and modify processes and determine compositional values for the final product. It is of great benefit to determine how well this process works with different types of waste in a full-size setting. The first information gathered is worth more than the rest of the information due to the absence of previous information. That is why the scales jump to $50 \%$ value on the first DST retrieved and decrease rapidly from there.

$$
\begin{aligned}
& \text { - } 0 \% \text { = } 0 \text { DSTs washed } \\
& \text { - 50\% = } 1 \text { DSTs washed } \\
& \text { - } 75 \%=2 \text { DSTs washed } \\
& \text { - } 90 \%=3 \text { DSTs washed } \\
& \text { - } 100 \%=4 \text { DSTs washed. }
\end{aligned}
$$

This scale assumes that $A Z-101$ has already performed its process test, which will determine similar information.

\section{Number of DSTs Retrieved}

Uncertainties exist concerning how well sludge can be retrieved from DSTs with proposed mixer pumps and transfer systems. The same reasoning as applicable to washing with DST sludge above, applies here. The scales are exactly the same.

- $0 \%=0$ DSTs retrieved

- $50 \%=1$ DSTs retrieved

- 75\% $=2$ DSTs retrieved

- $90 \%=3$ DSTs retrieved

- $100 \%=4$ DSTs retrieved.

\section{Sludge Washing and Leaching}

The purpose of sludge washing and caustic leaching is to reduce the anount of nonradioactive chemicals included with high-level waste (HLW) which must be converted to a high-integrity borosilicate glass and disposed of in a deep geological repository. Disposal costs for HLM are expected to far exceed that of low-level wastes (LLW).

Sludge washing is conducted to dissolve water-soluble salts and dilute the dissolved ions contained in the interstitial liquor of the sludge. In the present case of the high-heat sludges, there is no salt cake present in the sludge layer, but significant concentrations of soluble ions are present in the intersticial liquid (for instance, the sodium ion concentration may be as high as $5 N$ ). Sludge washing is expected to remove most sodium, potassium, sulfate, nitrate, nitrite, carbonate, hydroxide, and fluoride. Aluminum, phosphate, and chromium also will be removed to a lesser extent. The washing solution includes dilute concentrations of sodium hydroxide and sodium nitrite 
WHC-SD-WM-ER-532

Revision 0

(approximately $0.01 \%$ each) to prevent corrosion of the carbon-steel tank walls. These dilute chemical concentrations will not significantly impact washing efficiencies. The removal of the soluble intersticial chemicals (water washing) is conservatively assumed not to reduce the volume of settled solids.

Leaching with higher concentrations of sodium hydroxide ( $3 M$ to $6 M$ sodium hydroxide) is performed to decrease the concentrations of aluminum, phosphate, and chromium in the sludge where this is required to minimize the volume of HLW glass produced. Caustic leaching should be performed at elevated temperatures $\left(>50^{\circ} \mathrm{C}\left[>122^{\circ} \mathrm{F}\right]\right)$ to accelerate the dissolution of the aluminum, chromium, and phosphate.

Sludge washing and caustic leaching may be performed in the million-gallon aging waste tanks. The 300-hp mixer pumps installed for sludge retrieval operations will be used to suspend the sludge and mix it with the wash or leach solution.

Leaching with caustic will result in the dissolution of a portion of the sludge mass. Computer simulations with the Environmental Simulation Program for tank C-106 predict a 40\% reduction in the mass of water-insoluble solids. Cognizant engineering personnel have estimated no reduction in AZ-101 sludge mass due to the already high hydroxide concentration and slightly lower a) uminum content (30\% mass reduction in water-insoluble solids) for the other sludges present in the aging waste tanks. The percent reduction in the volume of settled solids is assumed to be equivalent to the mass reduction of water-insoluble solids. Although this assumed volume reduction appears to be reasonable, it has not been proven by laboratory work. Calculations to determine sludge height have assumed that when sludge is caustic leached there is a $40 \%$ volume reduction for $\mathrm{C}-106$ and a $30 \%$ volume reduction for sludge in $A Z-102, A Y-101$, and AY-102.

Sludges contained in the aging waste tanks have been settling for several years and have slowly compacted to a density well above that of a freshly settled sludge. When disturbed by sluicing, pipeline transfer, or mixer pump operation, the resettled sludges will occupy a volume that is more than twice that of the compacted sludge. Laboratory experiments conducted on 1,989 core samples of the sludges in tanks AZ-101 and AZ-102 indicated an expansion factor of 2 to 2.25. Because sludges have continued to compact since that time, a more conservative expansion factor of 2.5 is possible. Calculations in this report used 2.25 as an expansion factor.

The volume of sludge in a batch washing or leaching must be limited. Low sludge volumes are inefficient in terms of processing time and the effective use of chemicals and wash water. However, high-sludge volumes create problems in effectively diluting and decanting intersticial liquors and consequently require multiple washes/decants. Cognizant engineering personnel consider $3 \mathrm{~m}$ $(10 \mathrm{ft}$ ) of freshly settled solids (i.e., approximately one-third tank volume of fluffy solids) to be optimum and consider sludges heights above $6 \mathrm{~m}(20 \mathrm{ft})$ to be completely impractical. For rating purposes in this report, sludge heights of $3 \mathrm{~m}$ (10 ft) were given a $100 \%$ rating for processibility, decreasing linearly to $0 \%$ at heights of 0 and $6 \mathrm{~m}(20 \mathrm{ft})$. 
For the sludges that did not have caustic leaching/water washing specified (Oa, Ob, 2, 7, N1a, N1b, N3, N4, N5 [a, b, c] and N6), the potential for leaching and washing of the final resting settled sludge was evaluated under the topic "Fluffy Settled Solids." When solids had not been leached during movement through the tank farms, the solids could be leached if it was thought necessary before transfer to HLW vitrification. For example, in the alternatives in which final solids volume was over $6 \mathrm{~m}(20 \mathrm{ft})$ (NIb, N4, N5b, N5C, and N6) no value was assigned to this last alternative to leach and wash.

Water washing appears to reduce glass volume by reducing the sodium in the HLW glass. Two water washes have been assumed in the transfer scenarios.

Vienna and Hrma (1995) report that there is probably a negligible amount of reduction in glass volume when these particular sludges are caustic leached. The possible exception to this is that one of the two analyses of C-106 sludge showed some substantial glass volume reduction due to caustic leaching. This particular C-106 chemical analys is is generally not considered to be the more accurate of the two due to the poor ion balance. Overall, these results indicate that caustic leaching may not be warranted with this waste to reduce glass volume, but may have some benefit with demonstration of the technology. Assuming some benefit to caustic leaching, Alternatives la, $1 \mathrm{~b}, 3,4,5(\mathrm{a}, \mathrm{b}$, and $\mathrm{c})$, and 6 indicated caustic leaching of the sludge took place followed by water washing. A loss of up to $500 \mathrm{Kgal}$ of tank space occurred as the result of the caustic leaching scenarios.

The decision to leach and wash will depend on the chemical composition of the sludge, composition after blending with other sludges, the vitrification process used, and the glass formulation. If leaching and washing do not reduce the volume of the vitrification product, there is no monetary advantage to leaching. A benefit of caustic leaching these wastes appears to lie in the demonstration of the technology.

Because it is not planned to caustic leach AZ-101, any caustic leaching done with full-sized equipment will be a better demonstration of the efficiency and the design. Therefore, the first DST leached was given a higher score than DSTs sludge-retrieved or DSTs sludge-washed.

Number of DSTs sludge leached:

- $0 \%=0$ DST sludge leached

- $60 \%=1$ DST sludge leached

- $90 \%$ = 2 DSTs sludge leached

- $100 \%=3$ DSTs sludge leached.

In this report, both caustic leaching and no caustic leaching scenarios were evaluated in order to illustrate the impacts of the unit operation.

\section{Flexibility in Out-Year Processing}

To determine flexibility in out-year processing, the number of tanks with mixer pumps was summed. This indicates that having more support equipment and mixer pumps in the tanks is considered good. A linear scale was used. 
WHC-SD-WM-ER-532

Revision 0

\section{Fluffy Sottled Solids}

Fluffy settled solids are solids that have been agitated or mixed to disperse them. The number of feet of fluffy settled solids is critical when determining if it is worthwhile to wash or leach. Above $6 \mathrm{~m}(20 \mathrm{ft})$ of solids, the working space becomes 1 imited and many decants and transfers are required to fill and empty the tank. The factor used to convert from compacted solids to fluffy settled solids was 2.5 as previously discussed in the caustic leaching scales. The potential for performing washing or leaching was determined in this evaluation; the sludge did not have to be leached or washed to have the final in-place potential to be washed and leached.

Therefore, the triangular scale in Figure 3-2 (see Section 3.0 of main text) was generated.

\section{HLW Feed Avaflable}

The anount of HLH feed to vitrification is determined by the amount of feed in the tank(s) that have mixer pumps available. Because in every scenario the sludge is consolidated, the scale is simply the tank with the most volume of sludge that has a mixer pump.

It was assumed that the more sludge the more feed to HLW vitrification. This is not completely accurate because the composition of the sludge is critical to the formulation and final volume of the product. But it is an adequate, rough approximation for this analysis.

The evaluation scale was a "lazy $S^{\prime}$ curve of value versus volume with $50 \%$ value at about $155 \mathrm{Kgal}$ sludge. This is approximately equal to that called for in Bacon (1995). See Figure 3-2 in Section 3.0 of main text.

Avaflable Tank Space

\section{Assumptions}

The $5 H$ or $7 M$ sodium waste supernate used to fill tanks or supplement in-tank concentration efforts is assumed to be a low heat, clear, convective liquid that comes from Evaporator 242-A. This will be noncomplexed waste. Waste at $7 \mathrm{~K}$ Na was chosen to be put on top of aging waste solids because it is generally considered to be free of particulate and can produce a clean, convective liquid with minimal precipitates (Powell 1995).

Sludge transfer ratios average $3: 1$ water to sludge by volume, as assumed by WHC-SD-WM-ER-029 (Koreski and Strode 1995).

Washing consolidated sludge takes about five times as much water as the volume of sludge it cleans (Maclean and Powell 1995). When available, washing of sludge is performed twice. Slurry transport also performs sludge washing if dilute liquid waste is used.

Caustic washing of sludge requires a volume of $50 \%$ sodium hydroxide equal to $82 \%$ of the volume of consolidated sludge (Maclean 1995) for C-106. Of all the sludge in aging waste tanks, it is anticipated that only $C-106$ sludge may need to be caustic leached to lower vitrification product volumes. In 
Alternatives $1 a, 1 b, 3,4,5(a 11)$, and 6 , the alternatives were set up so a caustic leach is performed on $\mathrm{C}-106$ solids when mixer pumps are available. No caustic leaching is performed in the other alternatives.

Sodium hydroxide has a specific gravity of 1.35 at $32 \%$ and $0^{\circ} \mathrm{C}$. The sodium hydroxide was assumed to be diluted before getting to the tank, from $50 \%$ to $32 \%$, or about $60 \%$ dilution to ensure that the specific gravity 1 imit of 1.35 was adhered to.

\section{Observations}

Caustic leaching had the most impact on tank space due to the volume of storage space used by the spent caustic solution. The other major effect was the concentration to only $5 \mathrm{H}$ sodium in the "do nothing" alternative, $0 \mathrm{a}$.

\section{SCHEDULE}

\section{Start Date of C-106}

The start date of $\mathrm{C}-106$ was based on best estimates of the cost estimator. The major factors that influenced the delay of the C-106 start date were as follows.

- Reroute of the Project $W-320$ pipeline to other aging waste tanks, Alternatives 1a, $\mathrm{Nla}, \mathrm{N1b}$, and $1 \mathrm{~b}$, caused the $\mathrm{C}-106$ startup to be delayed to Aprif 1997.

- For Alternatives 4 and $\mathrm{N4}$, the reroute of the Project $W-320$ pipeline to AZ-102 may be complete by April 1997, but retrieval cannot start until October 1997 . The $\mathrm{C}-106$ retrieval will not be able to start up until after the $A Z-102$ supernate is removed from $A Z-102$. The second batch of AZ-102 supernate is staged to the AW Farm, but to avoid additional transfers of this high ${ }^{137} \mathrm{Cs}$ solution, we must wait on the evaporator to process the first $250-\mathrm{Kgal}$ batch of waste to avoid putting more than $70 \mathrm{KBtu} / \mathrm{h}$ in feed tank $\mathrm{AW}-102$. Processing the first batch of $A Z-102$ supernate is scheduled to take until September 1997, as noted on the Appendix A schedules for Alternatives 4 and N4.

\section{Schedule}

\section{End Date of Waste Consolidation}

Project schedules have a significant impact on the schedules for each alternative. The projects for installing mixer pumps and retrieval systems have the biggest impact on each of those alternatives which include retrieval and transfer of solids. In addition to retrieval and transfer of solids, mixing systems are essential to those alternatives which include in tank washing and leaching.

Existing project schedules were used to determine the schedule for equipment installation. In some projects, flexibility in the sequence of 
WHC-SD-WM-ER-532

Revision 0

events is possible if decisions are made well in advance of implementation. In particular, Project $\mathrm{H-211}$ installs mixer pump systems in several tanks. In each alternative, Project $\mathrm{W}-211$ installs mixer pumps in tanks SY-102 and AW-105 before installing mixer pump systems in any of the AY and AZ tanks. The order of mixer pump installation after the first two tanks is determined by choosing the tanks for installation which will result in the earliest completion of the operations within the alternative. The time between installation of mixer pump systems in each tank is about 1 year.

Project $W-320$ installs the retrieval system in tank $C-106$. This system is designed to retrieve the solids from C-106 into AY-102. Changing from AY-102 to some other receiver tank will change the project completion date by 1 year or more from the existing late fiscal year (FY) 1996 completion.

Project $\mathrm{W}-151$ is scheduled to complete installation of a mixer pump system into tank $A Z-101$ in FY 1996. Changing this project to put the mixer pumps into another tank is unfeasible at this late date.

Retrieval of solids from C-106 requires 3 to 4 months. Mixer pump transfer of solids from one DST to another requires about 2 months. Decanting liquid from one tank to another requires about 1 month. Leaching of solids requires about 6 months. Washing of solids requires about 4 months.

\section{Scheduled Impacts of Projects}

The $\mathrm{W}-030$ Project to replace the existing aging waste ventilation system will be installing a $1.6 \mathrm{KBtu} / \mathrm{h}$ condenser for AZ-101 compared to $1 \mathrm{KBtu} / \mathrm{h}$ condensers on all other aging waste tanks. The consolidation could require movement of the condenser for another aging waste tank. This could happen if the heat generated by the pumps or the waste was great enough. If this occurred, it could delay Project $\mathrm{W}-030$ by about 12 months. Scale evaluation indicated that in only one instance would this be necessary (Alternative 6). With more than $500 \mathrm{KBtu} / \mathrm{h}$ in tank $\mathrm{AZ}-102$, this is more reasonable and will provide more flexibility than being in $A Z-101$. The scale is a 0 - to 12-month delay.

\section{REFERENCES}

Bacon, R. F., 1995, Double-Shell Tank Waste Consolidation and Retrieval Planning Base Case (internal memo 73510-95-017 to C. A. Augustine et al., August 29), Westinghouse Hanford Company, Richland, Washington.

Bendixsen, R. B., 1990, History of Tank Bumps in Aging Waste Tank Farms, WHC-SD-WM-TA-021, Rev. 0, West inghouse Hanford Company, Richland, Washington.

Bergmann, L. M., 1994, Operating Specifications for Aging-Waste Operations in 241-AY and 241-AZ, OSD-T-151-00017, Westinghouse Hanford Company, Richland, Washington. 
HHC-SD-NM-ER-532

Revision 0

Jo, J., 1991, The History and Existing Evaluations of the Tank Bump, WHC-SD-WM-TI-406, Rev. 0, West inghouse Hanford Company, Richland, Washington.

Koreski, G. M., and J. N. Strode, 1995, Operational Waste Volume Projections, WHC-SD-WM-ER-029, Rev. 21, Westinghouse Hanford Company, Richland, Washington.

MacLean, G. T., 1995, Caustic for C-106 Leaching (cc:Mail message to W. J. Powe11, September 28), Westinghouse Hanford Company, Richland, Washington.

MacLean, G. T., and H. J. Powel1, 1995 (personal communication to W. J. Powel1, November 20), West inghouse Hanford Company, Richland, Washington.

Powe11, W. J., 1995, Concentration of Low-level Waste (LLW) Feed Using the Predict Model (internal letter 71210-95-005 to R. M. Orme and L. M. Swanson, March 23), Westinghouse Hanford Company, Richland, Washington.

Rice, P., 1995, Letter Report Tank 241-AY and 241-AZ Waste Evaporation, E62062LR, December, ICF Kaiser Hanford Company, Richland, Washington.

Rogers, C. A., 1994, CSER 94-001 Criticality Safety of Single Shell Waste Storage Tanks, WHC-SD-SQA-CSA-20363, ReV. 0, Westinghouse Hanford Company, Richi and, Washington.

Sederburg, J. P., 1994, Chenical Compatibility of Tank Wastes in 241-C-106, 241-AY-101, and 241-AY-102, WHC-SD-WM-ES-290, Rev. 2, West inghouse Hanford Company, Richland, Washington.

Squires, D. J., 1991, Aging-Waste Safety Analysis Report, WHC-SD-HS-SAR-010, Rev. 2, Westinghouse Hanford Company, Richland, Washington.

Tusler, L. A., 1995, Double-Shell Tanks Plutonium Inventory Assessment, WHC-SD-WM-TI-640, Rev. 0, Westinghouse Hanford Company, Richland, Washington.

Vai1, T. S., 1995, Criticality Prevention Specifications, Waste Stored in Double-Shell Tanks and Associated Equipient, CPS-T-149-00010, Rev. F-0, Mestinghouse Hanford Company, Richland, Washington.

Vienna, J. D., and P. R. Hrma, 1995, Glass Formulation for Phase I High-Level Waste Vitrification (this document does not have a number), Pacific Northwest Laboratory, Richland, Washington.

WHC, 1995a, Draft - Tank Farm Accelerated Safety Analysis, WHC-SD-WM-SAR-065, Rev. A, Westinghouse Hanford Company, Richland, Washington.

WHC, 1995b, Tank Farms Interim Operational Safety Requirements, WHC-SD-WM-OSR-018, Rev. 0, Westinghouse Hanford Company, Richland, Washington. 
WHC-SD-WH-ER-532

Revision 0

gLOSSARY

$\begin{array}{ll}\text { AWF } & \text { aging waste feed } \\ \text { DST } & \text { double-shell tank } \\ \text { HLW } & \text { high-level waste } \\ \text { HPT } & \text { health physics technician } \\ \text { IDLH } & \text { imnediately dangerous to life or health } \\ \text { LFL } & \text { lower flammability limit } \\ \text { LLW } & \text { low-level waste } \\ \text { NPO } & \text { nuclear power operator } \\ \text { PIC } & \text { person in charge } \\ \text { QC } & \text { quality control } \\ \text { RWP } & \text { radiation work permit } \\ \text { SST } & \text { single-shell tank } \\ \text { TOC } & \text { total organic carbon } \\ \text { USQ } & \text { unreviewed safety question }\end{array}$


WHC-SD-WM-ER-532

Revision 0

This page intentionally left blank. 
WHC-SD-WH-ER-532

Revision 0

APPENDIX D

REYIEY CONHENT RECORDS

D-1 
WHC-SD-WM-ER-532

Revision 0

This page intentionally left blank.

D-2 


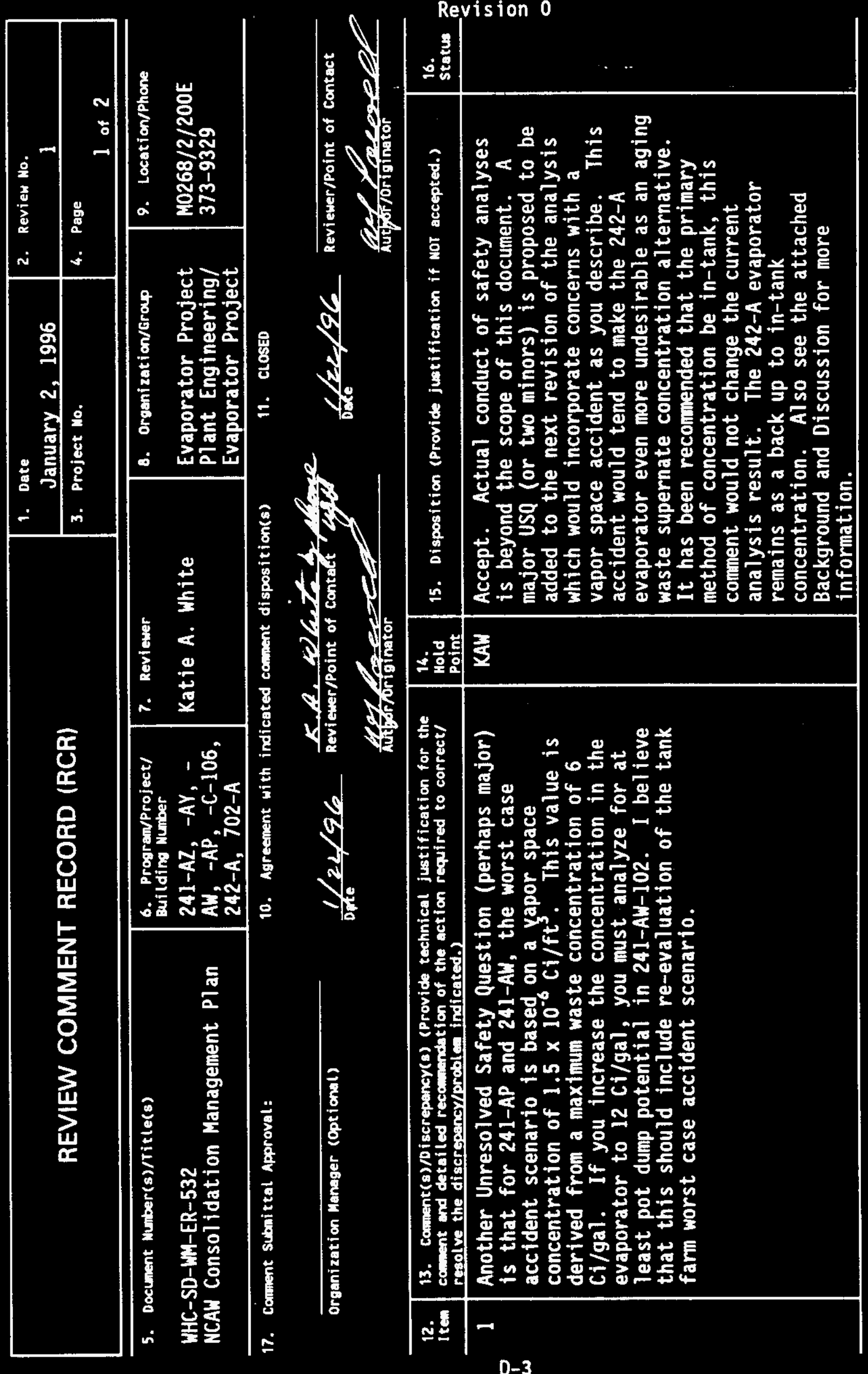




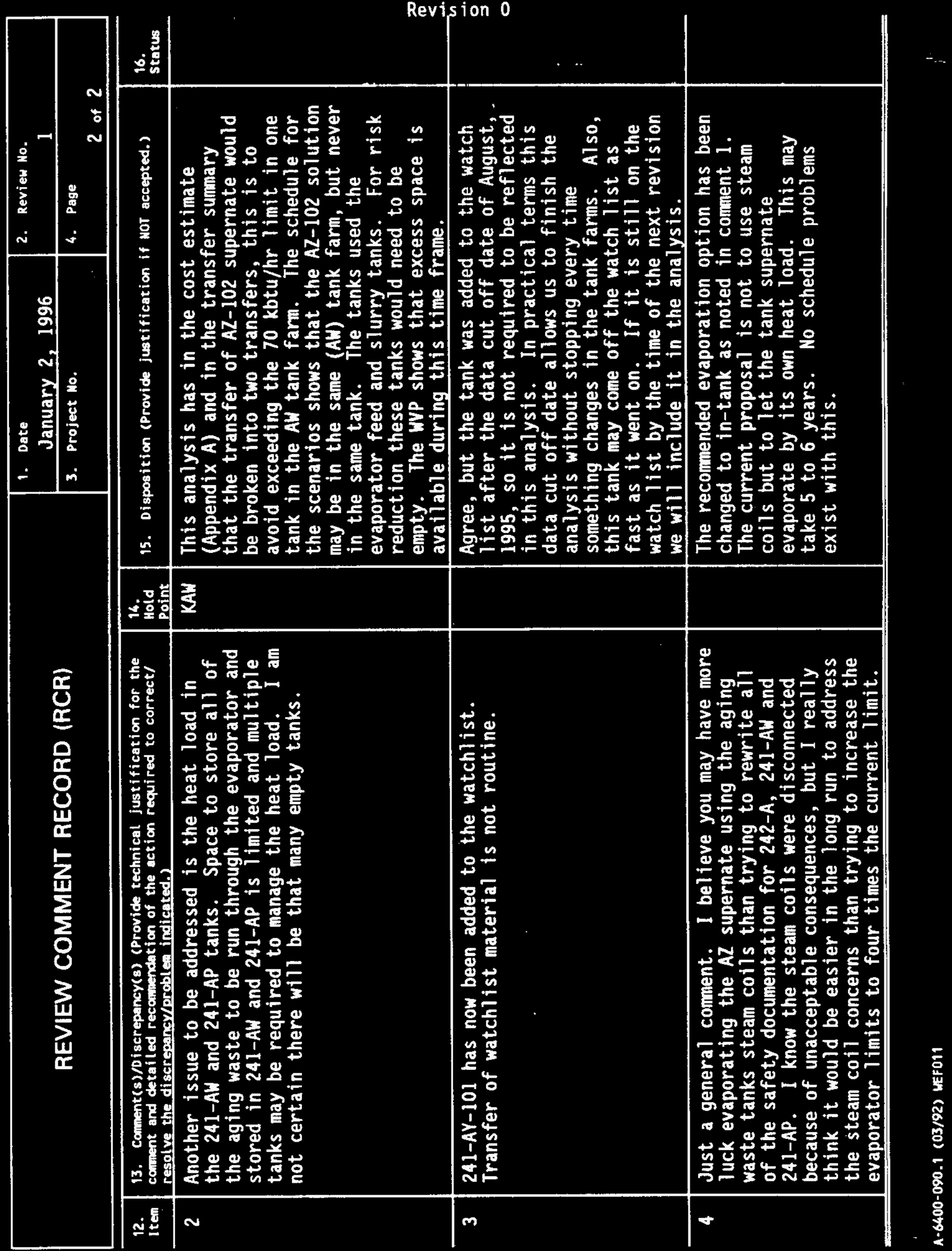




\section{REVIEW COMMENT RECORD (RCR)}

\begin{tabular}{|l|l|}
\hline $\begin{array}{l}\text { 1. Date } \\
\text { January 2, 1996 }\end{array}$ & \multicolumn{1}{|c|}{ Review No. } \\
\hline 3. Project No. & 4. Page \\
\end{tabular}

Kat ie A. White, RCR Responce coment 1, (cont inued) - 1/15/96

Background and Discussion:

The concentration of the aging waste supernatant 1 iquor to $111 \mathrm{GBq} / \mathrm{L}\left(12 \mathrm{Ci} / \mathrm{gal}\right.$ ) ${ }^{137} \mathrm{Cs}$ significantly and directly affects three aspects of safety analysis in the manner described by the reviewer. The first safety analysis affected by such concentration is that of shielding analys is in the evaporator; this management plan has considered such shielding analyses among minor USQs as criterion I.C.2.b.(6) in section 3.1.2.3. The second safety analysis affected by such concentration is that of an evaporator accident (criterion I.C.2.a.(1)) as a major USQ; such a USQ would be derived, at least in part, due to concerns of a pot dump and tank overpressurization. The third safety analysis affected by such a concentration is that of a ventilation failure of the AN tank farm; ventilation failure analyses are intimately tied to the operation of the air lift circulators (ALC) for the farm and should be recognized to be required to be a part of an ALC USQ.

Applicable safety analyses documents include WHC-SD-WM-SAR-016 for the tanks and -023 for the evaporator. It is recognized that WHC-SO-WM-SAR-023 shielding analysis generally does not exceed analysis for cesium activities in excess of $5 / 12$ what is described in this management plan, as such, additional shielding analyses and shielding emplacement of would be expected and/or required for execution of this work.

Although the AH farm overpressurization concern from a pot dump is a true concern to be evaluated as an anticipated event (historical), it is possible that the combined probability of a pot dump of $>55 \mathrm{GBq} / \mathrm{L}(6 \mathrm{Ci} / \mathrm{gal}) \mathrm{near}$ the end of the evaporation of this liquor may reduce overall probability below that of anticipated accidents $\left(1 \rightarrow 10^{-2}\right)$ to that of the unlikely $\left(10^{-2} \rightarrow 10^{-2}\right)$. In the analytical methods and guidance of WHC-CH-4-46, dose consequences 'considered' acceptable offsite/onsite for the categories of anticipated, unlikely, and extremely unlikely events are $5 / 25$, and $50 / 250$, and $100 / 1000 \mathrm{mSV}(1 \mathrm{mSv}=0.1 \mathrm{rem})$, respectively. In the safety analysis of overpressurization, the material concentrations of a vector of radionuclides were assigned vapor partition fractions in order to estimate vapor concentrations of the materials and thus derive a source term for dose consequence analysis. The vapor partition fraction used in -016 is approximately four times the maximum historically observed partition fractions in aging waste tanks with air lift circulators in operation. It is reasonable to believe that reanalys is of the event probability and consequences (not limited to radionuclides) will lead to the acceptance of the risks of proceeding with NCAN consolidation including supernatant liquor evaporation to $111 \mathrm{GBq} / \mathrm{L}$.

The concern of ventilation failure of the AW farm is in many ways linked to the overpressurization analysis. In this accident analysis, filters loaded with material collected (a function of vapor space concentration) for some period of time are blown out releasing contaminants. Under the current dose consequence analyses for this bounding accident, for wastes with ${ }^{137} \mathrm{Cs}$ concentrations of $61 \mathrm{GBq} / \mathrm{L}(6.59 \mathrm{Ci} / \mathrm{gal})$ onsite and offsite consequences are estimated to be 670 and $0.37 \mathrm{mSv}$ and are considered acceptable risks. If all other accident parameters remained the same, the dose consequence 


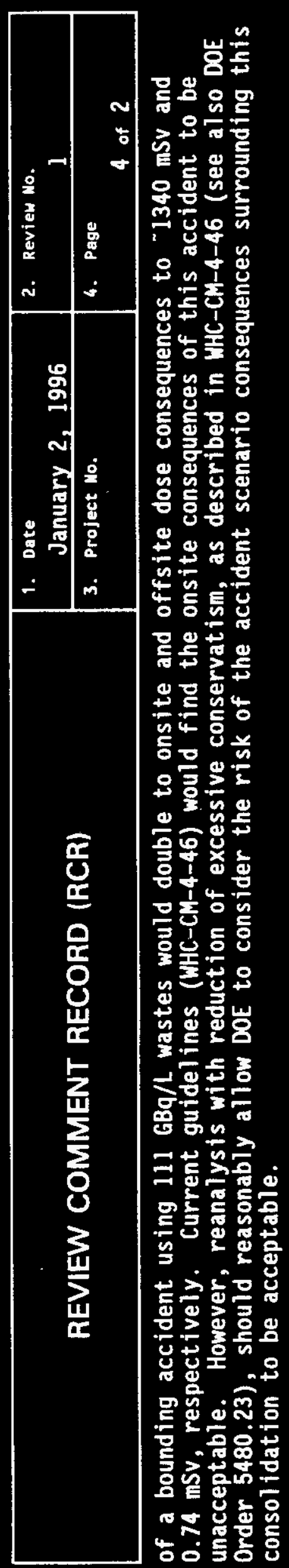




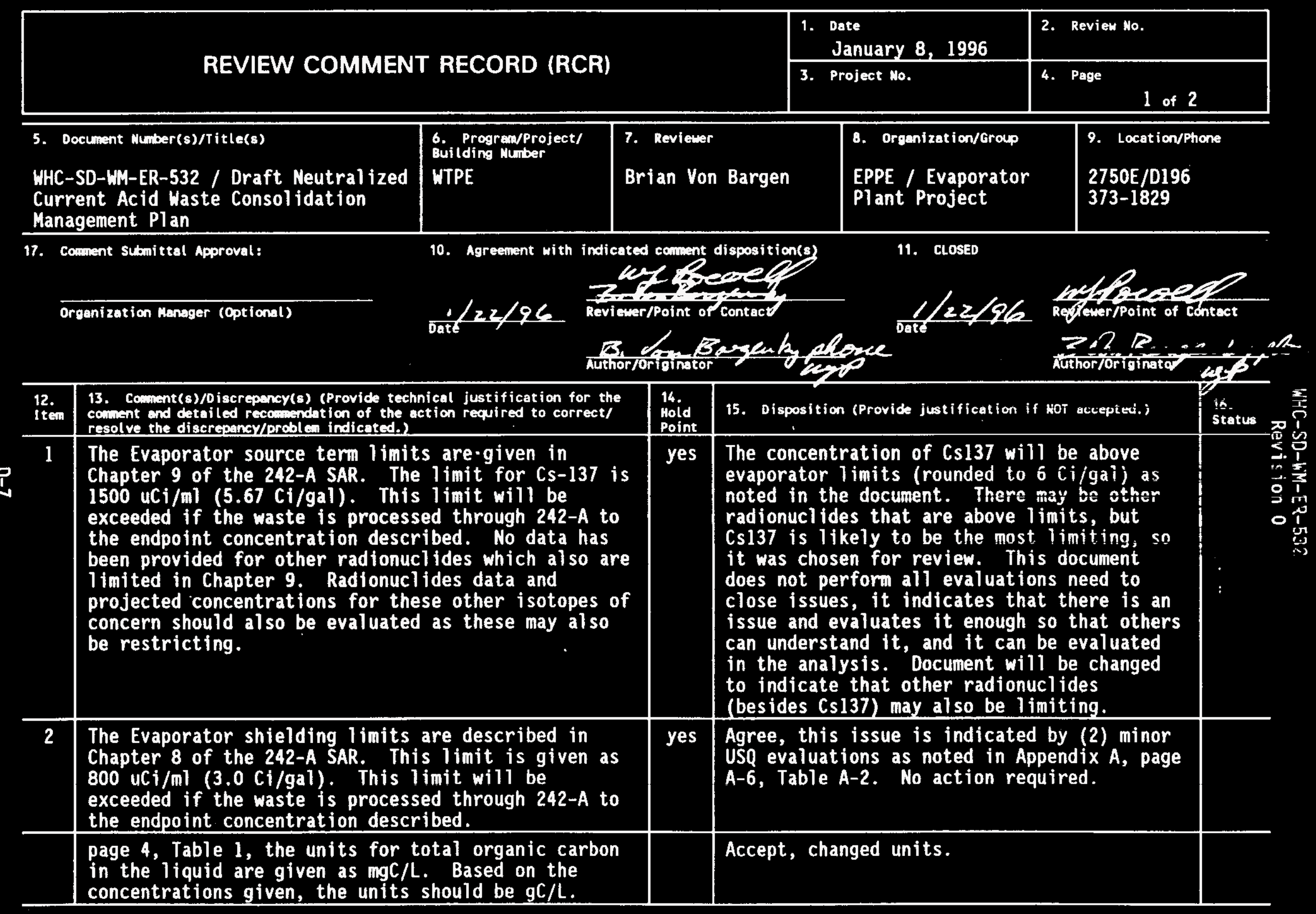




\begin{tabular}{|c|c|c|c|c|c|}
\hline \multirow{2}{*}{\multicolumn{3}{|c|}{ REVIEW COMMENT RECORD (RCR) }} & $\begin{array}{l}\text { 1. Date } \\
\text { January 8, } 1996\end{array}$ & \multicolumn{2}{|l|}{ 2. Review Mo. } \\
\hline & & & 3. Project Mo. & 4. Page & \\
\hline $\begin{array}{l}12 . \\
\text { Item }\end{array}$ & $\begin{array}{l}\text { 13. Coament(s)/Discrepancy(s) (Provide technical justification for the } \\
\text { comment and deteiled recombendation of the action required to correct/ } \\
\text { resolve the discrepansy/problem indicated.) }\end{array}$ & $\begin{array}{l}\text { 14. } \\
\text { Hold } \\
\text { Point }\end{array}$ & \multicolumn{2}{|c|}{ 15. Disposition (Provide justification if NOT accepted.) } & $\begin{array}{l}16 . \\
\text { status }\end{array}$ \\
\hline 4 & $\begin{array}{l}\text { section } 3.1 .2 .3 \text {, "A. Minimize personnel risk" - was } \\
\text { exposure to laboratory personnel during sample } \\
\text { handling and analys is evaluated? Also include } \\
\text { evaporator process control samples along with the } \\
\text { listed tank samples in "a.". With the increased } \\
\text { level in exposure due to high Cs-137 (and possible } \\
\text { other isotopes), item e. should be added which would } \\
\text { be exposure to evaporator personnel during waste } \\
\text { concentration operations. }\end{array}$ & yes & \multicolumn{2}{|c|}{$\begin{array}{l}\text { Accept, in talking with laboratory personnel } \\
\text { (John Miller) they will receive on average } \\
20 \text { to } 30 \text { mrem/person during sample handl ing } \\
\text { and analysis. Samples usually take } 1 \text { to } 3 \\
\text { personnel to analyze. Using an average of } 2 \\
\text { personnel, and } 25 \text { mrem and assuming about } 10 \\
\text { samples/aiternative (will vary) = 500 mrem } \\
\text { This is less than the } 2 \text { significant figures } \\
\text { used in the analysis. } \\
\text { In the scales "Personnel Risk" extends from } \\
14,000 \text { to } 23,000 \text { mr, with the more involved } \\
\text { scenarios having the higher dose. These } \\
\text { exposure levels would not change the options } \\
\text { chosen by the criteria. However, they will } \\
\text { be added in the next revision of the } \\
\text { document. To assure that this happens this } \\
\text { RCR will be added to the document in an } \\
\text { appendix. }\end{array}$} & 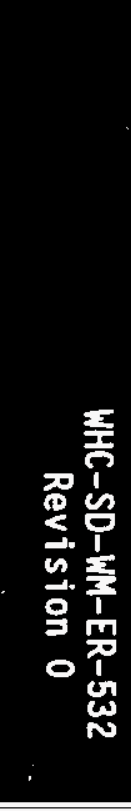 \\
\hline
\end{tabular}

